

for 200 

(2)

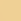



THE LIFE AND LETTERS OF SIR JOHN HENNIKER HEATON 



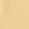




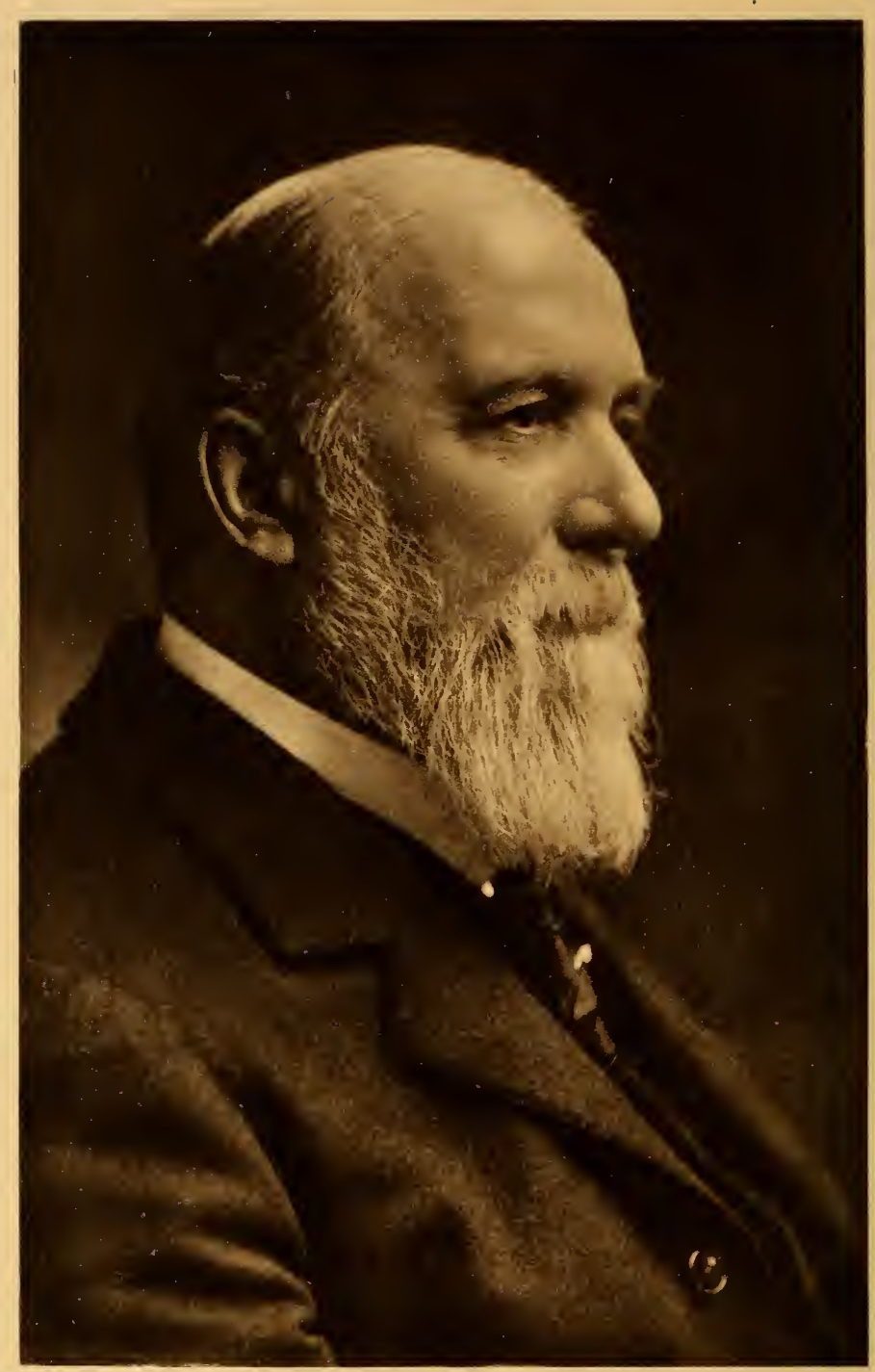

"O Shall not regard my wort as completer until time and space have been annihilated and the scaltered coasts of the Omprire have bicen so united that we can speak to the peofle of New Lealand as casily as I am speaking to this company."

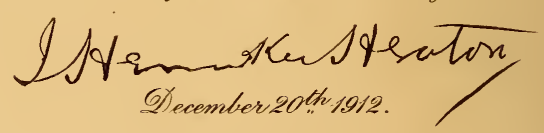




\section{THE LIFE AND LETTERS OF}

SIR JOHN HENNIKER HEATON BT. BY HIS DAUGHTER MRS ADRIAN PORTER WITH NUMEROUS ILLUSTRATIONS

B

$D A$

565

H45 P6X

1916

NPM

In my opinion the work of Sir Jobn Henniker Heaton has done more to draw the Empire together than all the speeches of all the statesmen on both sides of the ocean.

Earl Curzon of Kedleston. 1912.

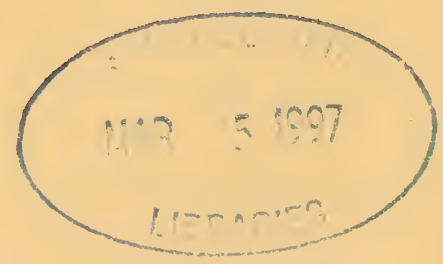

LONDON JOHN LANE THE BODLEY HEAD NEW YORK JOHN LANE COMPANY MCMXVI 
Printed in Great Britain by Turnbull \& Spears, Edinburgh 
TO OUR DEAR MOTHER

THIS BOOK IS INSCRIBED

WITH THE

ADMIRATION AND LOVE

OF HER

CHILDREN AND GRANDCHILDREN 



\section{FOREWORD}

BY THE RIGHT HONBLE. SIR GEORGE REID, P.C., G.C.M.G., HIGH COMMISSIONER FOR AUSTRALIA

T KNEW Sir John Henniker Heaton well in Australia, and since I909 well in England. Perhaps the two leading attributes of his personality 1 -on the emotional side-were his intense public spirit and his unfailing geniality. Loving hands have written his life. As one of the inner circle of his friends, I can add a hearty endorsement of the filial tribute to his memory.

I came to know him many years ago. Mr Samuel Bennett brought us together in Sydney. Mr Bennett was one of the best Englishmen I knew in Australia. By sheer force of character, backed up by a robust intellect, with little capital and no patronage, he established the fortune of two most successful newspapers in Sydney, one a daily and the other a weekly. What is more, Samuel Bennett was in the forefront of those public benefactors whose success, great as it was, was not greater than the fine impression it enabled him to make upon public opinion and Australian journalism.

The fact that such a man "took to" the subject of this biography and gave him his important start in life, as well as his only daughter, who was the crowning happiness of Sir John Henniker Heaton's life, in itself "speaks volumes" in favour of the man who afterwards became " the Member for Australia." 
I suppose no man outside ministerial circles exercised a stronger or more useful influence upon "red tape" administration during the past thirty years than did this great Postal Reformer.

In many ways the tremendous obstacles to numan intercourse, which distance involves, have been iessened by modern invention and commercial enterprise. But for the labours of Sir John the splendid successes that have been slowly but surely won by that David of Reform over the Goliath of Post Ofice routine might have been indefinitely postponed. Sometimes such humanizing victories are dearly bought. Not so with a system of penny postages covering worldwide distances. Not so with the marvellous expansion of electrified messages between mind and mind and market and market, which means the creation of new worlds of intellectual as well as industrial progress.

Those great achievements have been a source of wealth beyond "the dreams of avarice" in the case of private enterprise, and the fears of ruin which daunted the custodians of postal revenues have been converted into magnificent profits.

The bodily presence of our friend has returned to dust, but his spirit may often look down gladly upon world-wide spheres which have been brightened by his devoted dauntless labours-labours that contain germs of even greater blessings in the years to come. 


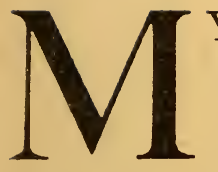

Y grateful thanks are due to Earl Curzon, Lord Blyth, Lord Beresford, Sir George Reid, Sir Charles Bruce, Mr Herbert mendatore Marconi, Mr Wilfrid Meynell, Mr T. P. O’Connor, Colonel R. W. Renshaw, Mr William Heaton, Mr Harry Brittain, and Mrs Algernon Paget, for the help they have given me; and to all those who have kindly allowed their letters to be published.

My acknowledgments are also due to the Editors of The Times, The Nineteenth Century, The Daily Graphic, The Graphic, and to the Editor of The Leisure Hour, for permission to quote at length from an article in that Magazine, entitled "The Mother of Parliaments" (Chapter II.).

The postal statistics and facts are taken in all cases from my father's publications and private notes. 



\section{CONTENTS}

CHAP. PAGR

I. A BRIEF BIOGRAPHY . $\quad$. $\quad$. $\quad$. 3

II. As Member for Canterbury in the House • I3

III. As Member for Canterbury in the Constituency 39

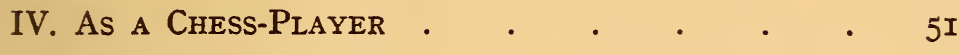

V. As a Traveller. I. By Land * • • 57

VI. As a Traveller. 2. By Water . . . 70

VII. As A HoST

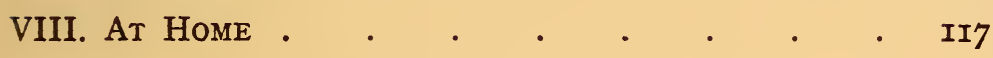

IX. A Pen Portrait • . • . • . . $\quad$ I26

X. A Chapter by T. P. O'Connor - • . I3I

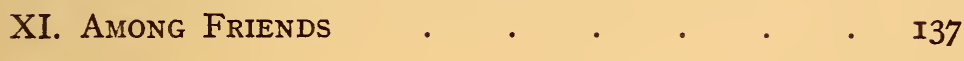

XII. Some Australian Memories . $\quad . \quad$. $\quad{ }^{2} 5^{8}$

XIII. As a Postal Reformer . . . . . . I7I

XIV. As a Postal Reformer (continued) • • . $\quad$ Ig8

XV. The Fight for Penny Postage with Australia 2I5

XVI. Penny-a-Word Telegrams • • • • 222 


\section{xii SIR JOHN HENNIKER HEATON}

CHAP.

XVII. An Ideal Post Office

XVIII. RECOGNITION

232

XIX. Requiescat in Pace

APPENDIX .

240

INDEX

55

283 


\section{LIST OF ILLUSTRATIONS}

Sir John Henniker Heaton. Photogravure . Frontispiece

“ROSE LORRaine" Lady HenNiker Heaton

H. H. (aged 36) When he first entered Parliament . I4

Cartoon by F. C. G., "Different Points of View" . 38

A Luncheon Party given by Sir Benjamin Stone in the

House of Commons . . . . . . 56

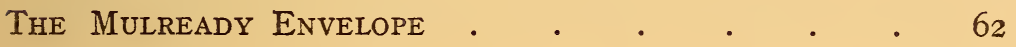

Envelope issued by Elihu Burritt advocating Ocean

Penny Postage .

Facsimile Letter from Elihu Burritt • • • 70

Commendatore Guglielmo Marconi • • • $\quad 98$

H. H. And Marconi on Coronation Day, igo2, at the

House of Commons . . . . . . . . Io6

Lady Henniker Heaton . . . . . . . II6

In the Chair: H. H. at the Savage Club . . . I44

LETtER FRom MARK Twain to H. H. ACKNOWLEDGing hIS

Indebtedness for Money Saved in Postage . • I92

First LetTer From America to England bearing a

PENNY Stamp . . . . . . . . . $I 92$ 
xiv SIR JOHN HENNIKER HEATON

Old Letter from Australia bearing Sixpenny Stamp, I886

First Aerial Letter posted in England, igit . . 2i6

First Letter posted to Australia by H. H., Bearing the Penny Stamp, I905 .

First Letter posted by the P.M.G. of Australia, The Hon. Josiah Thomas, bearing a Penny Stamp, IgII 2 I8 The Martin Luther of the Post Office . . 232

Facsimile Letter of the American Vice- and Deputy Consul at Karlsbad, Dated 3ISt August IgI4 • 248 
THE LIFE AND LETTERS OF SIR JOHN HENNIKER HEATON 



\section{THE LIFE AND LETTERS OF SIR JOHN HENNIKER HEATON}

\section{CHAPTER I}

\section{A BRIEF BIOGRAPHY}

MAN of Kent, John Henniker Heaton was born at Rochester, on the I8th of May, 1848. He was the only son of Lt.-Colonel John Heaton, of Heaton, Lancashire, born I8Io, who married, May 8th, I84I, Elizabeth Anne, daughter of John Henniker, ${ }^{1}$ of Rochester, and died I856.

The early years of John Henniker Heaton's life were spent in the old Cathedral city of Rochester, where his father was quartered. His happiest memories of boyhood were those of the long summer hours he spent bathing in the Medway and, after a swim, lying on the banks reading and re-reading his favourite books, "The Pathfinder" and "The Last of the Mohicans," and dreaming the long, long dreams of boyhood.

$\mathrm{He}$ had an almost passionate love for books of adventure and sea voyage, a love intensified, perhaps, by the rigid discipline of his home, where day-dreams were forbidden, and unquestioning obedience enjoined as the chief virtue of childhood.

'See "Hennikers of Senham," in Hasted's "History of Kent.' 
He was educated at Kent House School, an old double-fronted Georgian building of rather curious aspect, which is now a private house. As a schoolboy, the future Postal Reformer was remarkable chiefly for his gift of memorizing poetry and prose. At the age of ten he knew by heart the whole of Pope's "Essay on Man," and could recite page after page of Motley's " Rise of the Dutch Republic." The historic associations of old Rochester, the Cathedral, the Castle overlooking the great stretch of river, could hardly fail to arouse in a boy feelings of romance and adventure.

At the age of sixteen, after pursuing his studies at King's College, "Adventure lit her stars" for him, and he was free to roam the world at his will.

In those days Australia was looked upon as a kind of Promised Land for younger sons, and their impoverished elder brothers, and it was to Australia that John Heaton's eyes were eagerly turned. With a light heart and a still lighter pocket, he left England for the country of sunshine that was to be his adopted home for many years, and where after some vicissitudes he was to gain his first experience of the good fortune that followed him ever after. Those who knew him at that period speak of him as a tall, thin youth, with deep hollows showing beneath his high cheek bones, eyes large and kindling and an indescribable "something " that marked him out.

The first part of his life in Australia was spent in the bush, where he found employment on the great sheep stations. With no previous experience of agricultural life, he made all the blunders and mistakes peculiar to young Englishmen fresh out from 
home. Here he built up the iron constitution that was to stand him in such good stead in later years, and here, too, he made friendships that were to last as long as life itself. During the months he spent in solitary rides from one isolated station to another, the seeds were sown of his future campaign in the cause of cheapening postal and telegraphic communication throughout the world.

Leaving the bush, John Heaton spent some happy years in Parramatta, where he joined the staff of "The Mercury." For three months, December I869February I870, he acted as Town Clerk of Parramatta. Fate, "playing her wonted phantasy," decreed that he should next edit a paper in Goulbourn with the predestined title "The Penny Post." From "The Penny Post" he passed on to "The Times"-of Parramatta-a natural transition in view of the part he was later to act as connecting link between another "Penny Post" and another "Times."

His next move was to Sydney, where he joined the staff of "The Australian Town and Country Journal." This journal and "The Evening News" were owned by Mr Samuel Bennett, the doyen of Australian journalists, and author of an exhaustive work on Australian history.

$\mathrm{Mr}$ Bennett was a remarkable example of the men of high character who in those early days had already succeeded in making the Australian press honoured and respected. Though he was never in Parliament, no Cabinet was ever formed without obtaining his views and advice. The son of a Cornishman, he united in his personality the integrity and bluntness of speech of his compatriots with the kindest of hearts and the most generous of instincts. "A 
hater of sham and humbugs" was said of him in his life and might serve for his epitaph.

"He was the best friend I ever had" was the description of him given by John Heaton, who was deeply grateful for the good fortune that brought him under the influence of $\mathrm{Mr}$ Bennett's erudition.

After working some time on "The Australian Town and Country Journal" there came a memorable day when John Heaton was bidden to luncheon at $\mathrm{Mr}$ Bennett's home. Presiding over the table was the lady who was to share his life for forty-one years of radiant happiness. Rose Bennett was the only daughter of the house, and the beloved sister of her three younger brothers. There is a charming portrait of her at this period, showing her dark wavy hair parted in the middle and her soft dark eyes. It was perhaps more her sweetness of expression, gentle voice and dignity of bearing than any special regularity of feature that won for her the admiration she received in so large a measure. She is celebrated as "Rose Lorraine" in the poem of that name by Henry Kendall. This poem has been described as one of the three saddest love-poems in the English language.

\section{ROSE LORRAINE}

Sweet watermoons blown into lights

Of flying gold on pool and creek,

And many sounds and many sights

Of younger days are back this week.

I cannot say I sought to face

Or greatly cared to cross again

The subtle spirit of the place

Whose life is mixed with Rose Lorraine. 


\section{A BRIEF BIOGRAPHY}

What though her voice rings clearly through

A nightly watch I gladly keep,

No wish have I to start anew

Heart fountains that have ceased to leap,

Here face to face with different days And later things that plead for love,

It would be worse than wrong to raise A phantom far too fain to move.

But, Rose Lorraine-ah, Rose Lorraine, I'll whisper now where no one hears,

If you should chance to meet again The man you kissed in soft dead years,

Just say for once, "He suffered much," And add to this-" "His fate was worst

Because of me-my voice my touch" There is no passion like the first.

If I that breathe your slow sweet name, As one breathes low notes on a flute,

Have vexed your peace with word of blame, The phrase is dead, the lips are mute.

But when I turn towards the wall

In days of storm -in nights of rain,

I often wish you would recall

Your tender speeches, Rose Lorraine.

Because you see I thought them true And did not count you self-deceived, And gave myself in all to you, And looked on love as Life achieved. Then came the sudden bitter change, The fastened lips, the dumb despair, The first few weeks were very strange, And long and sad and hard to bear.

No woman lives with power to burst My passion's bonds and set me free, For Rose is last where Rose was first, And only Rose is fair to me.

The faintest memory of her face, That wilful face that hurt me so, Is followed by a fiery trace

That Rose Lorraine must never know. 
I keep a faded ribbon string

You used to wear about your throat, And of this pale-this perished thing, I think I know its threads by rote. God help such love, to hold your hand, To linger where your feet might fall, You marvellous girl! my soul would stand The worst of hell-its fires and all.

On July I6th, I873, the marriage between John Henniker Heaton and Rose Bennett took place at St James's Church, Sydney.

No one who knew John Heaton intimately could doubt that he owed much of his success to the happiness of his married life, where he found in his wife the sympathy and companionship that is so essential to a public man. Those meeting Lady Heaton for the first time little dreamed of the depth of character that lay beneath her gracious gentle manner. Her sincerity of heart, her loyalty to friends and her intense love of truth won the respect of all her circle. Her sound critical judgment was greatly valued by her husband, who never wrote an article or prepared a speech without referring it to her opinion.

On her advice he would leave out what he described as "the best part of all," but when results had justified the omission he was the first to acknowledge its wisdom. Sir John and Lady Henniker Heaton remained lovers all their life: when separated, not a day passed without an interchange of letters; and he spoke of her always as "my dear little wife."

During the early years of their married life John Heaton nearly succumbed to an attack of typhoid fever. Hope was given up by the doctors, and in consequence of a premature notice of his death in the 


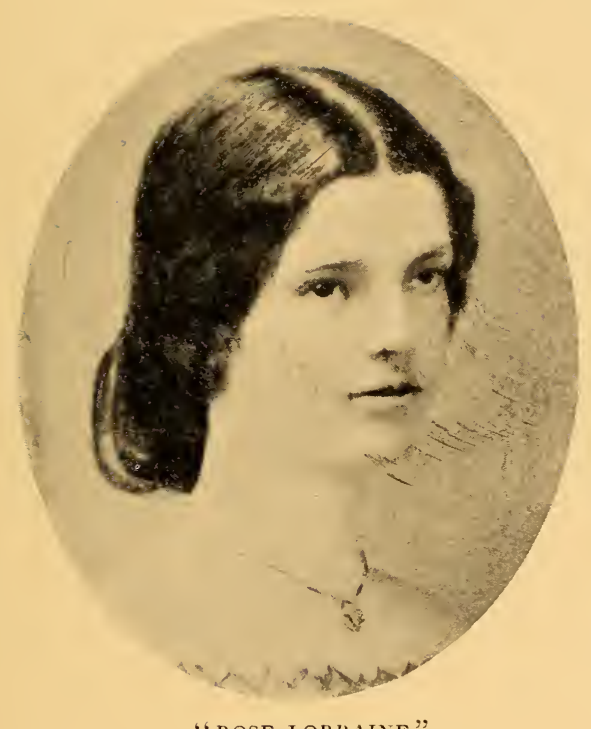

"ROSE LORRAINE"

(LADY HENNIKER HEATON) 

newspapers a funeral wreath arrived at the house! But his wife's devoted nursing undoubtedly saved his life. When all hope was over and he was thought to be sinking, she had the courage to disobey the doctors, who had stopped further nourishment as useless. She insisted on continuing the treatment so long as life remained unextinguished. Her calmness and courage won the day, and she had the joy of nursing him back to restored health and vigour.

For ten years after their marriage they made their home in Australia, during which time John Henniker Heaton became connected with the public life of Sydney. He was the author of a standard book of reference, " The Australian Dictionary of Dates and Men of the Time."

In I882, he stood for Parliament as a candidate for the electorate of young New South Wales, but was defeated by a small majority. Mr P. W. Crowe, of Brisbane, has supplied the following notes:

"It is now three and thirty years since I first met Sir John Henniker Heaton, when I was a candidate with him in his first entry into political life.

"He was then in the prime of life, a man of imposing presence, well built, tall, dark, and active, while his bearing was extremely courteous and kind to all.

"The elections of New South Wales about this time were of an exciting character. The education question was at fever height. The abolition of state aid to Denominational Schools was uppermost in the minds of the people. Archbishop Vaughan took a great part in the controversy as well as other Roman Catholic and Anglican Clergy, who eloquently opposed the onslaught of the Parks Government on the schools. 
"We threw in our lot with the denominationalists, and fought for the rights of conscience. The two other issues we put before the electorate were the crediting of the annual rent payable to the Crown by selectors in payment of the purchase money, and the policy of protection. The former would help to settle people on the land and the latter to convert N.S.W. into a manufacturing country. The policy which we advocated is now the policy of not only N.S.W. but all Australia.

"These were the days of the roaring camp when Timora Gold Field broke out. There were upwards of Io,000 miners in the field of whom few, unfortunately for us, had votes. We had their sympathy, their substantial help, and their regrets when we were defeated at the ballot box by a very small majority.'

For John Henniker Heaton this was a disappointment that was to have far-reaching results. It turned his thoughts to England, and a parliamentary career that might be open for him in his native country as member for a Kentish constituency.

In $\mathrm{I} 883$ he represented New South Wales as Commissioner at the Amsterdam Exhibition; he also represented Tasmania at the Berlin International Telegraphic Conference, where he succeeded in getting a very large reduction in the cost of cable messages to Australia. He was appointed Commissioner for New South Wales at the Indian and Colonial Exhibition in London in I886, and throughout his life he never ceased to forward Australian interests. "The Member for Australia" was a name conferred on him.

The year I884 saw him and his family settled in London, which was henceforth to be their home.

At the General Election of I885, John Henniker 
Heaton was returned as Conservative member for Canterbury, which seat he held for twenty-six years, when ill-health caused him to retire from Parliament at the dissolution of IgIo.

His work as a Postal Reformer is dealt with fully in another part of the book. His title by common consent was that of Father of Imperial Penny Postage. Owing to his exertions, the cost of cabling to different parts of the world was very greatly reduced. Imperial Penny Postage first came into force on Christmas day I898; Anglo-American postage was won by him in I908; Anglo-Australian Penny Postage I905-I9II.

His valuable work was warmly recognized. The Freedom of the City of London was presented to him in a gold casket in July I899, and in the same year he was given the Freedom of the City of Canterbury in a silver casket.

In IgII, while visiting Australia, a baronetcy was conferred on him, and on his return a public welcome at the Guildhall was given to him under the auspices of the British Empire League. Distinguished representatives of the Empire, presided over by Lord Curzon, were gathered together to do him honour.

Sir John Henniker Heaton refused a K.C.M.G. four times; on the last occasion, owing to his absence abroad he was actually gazetted, but he never used the title.

He was succeeded by his eldest son, John, and Lt. Welsh Horse, who was born I877, and served with roth Batt. Oxford Yeomanry in South Africa (medal, 3 clasps). He married, in I902, The Hon. Katharine Mary Sermonda Burrell, only surviving child of the 
fifth Baron Gwydyr, and has three sons and one daughter.

This then, in brief, is the life story of the Postal Reformer, Sir John Henniker Heaton.

It has been thought best to divide the book into chapters illustrating the different characteristics and divers interests of Sir John as Postal Reformer, Politician, and Traveller.

Some one once said to him that his great work would never be forgotten.

" Perhaps not," he replied, " but all my good stories will be forgotten, even by my children."

An endeavour has been made in these pages to preserve some of his favourite stories of his fellow-men and their doings.

It may be urged that, in trying to paint a picture of Sir John and his contemporaries, the canvas has become so overcrowded that there is a danger of being " unable to see the wood for the trees." I can only say that it is impossible to visualize Sir John as a solitary figure. Always one sees him surrounded by a crowd of friends, always one hears his hearty laugh ringing out above the rest. So clear grows the vision that even as I write I can almost see the familiar group-almost hear the happy voices. 


\section{CHAPTER II}

\section{AS MEMBER FOR CANTERBURY}

\section{IN THE HOUSE}

$\mathbf{I}$

$\mathrm{N}$ I885 H. H. made a pilgrimage to Canterbury to seek the suffrage of the ecclesiastical capital of the Empire. The morning he left London his Club by Lord Halsbury, who thrust a kindly arm through his, saying :

"I hear you are going down to Canterbury. They are sure to ask you if you are in favour of payment of Members, but you must reply that you are in favour of the good old practice of payment for voters and a pension for them afterwards."

After an agreeably contested fight, $\mathrm{H}$. H. was duly elected Conservative Member for Canterbury with a majority of rather over a thousand.

Never a good speaker, $H$. H. from the first devoted his energies to harassing the life of the PostmasterGeneral-then Mr Cecil Raikes-by asking questions on Post Office Administration. H. H.'s persistent questioning, if a source of irritation to the PostmasterGeneral, was the cause of some amusement to the House of Commons.

Old members will recall the cheers and laughter that greeted the announcement that " the Honourable Member for Canterbury will be relieved to hear that henceforth 'mother-in-law' will be counted as 
one word in a telegram, and an additional grievance to the relationship will thus be removed." The Honourable Member for Canterbury replied that he was not in a position to benefit by the change, as he grieved to say that his mother-in-law had long been in a better world. His efforts for the reform had been made solely on behalf of Honourable Members who were not so unfortunately situated as himself.

The use of questions in the House, which $\mathrm{H}$. $\mathrm{H}$. found so effective a weapon, did not however commend itself to all the members of his family. There was a small midshipman son who did not fail to express his views on the matter. One day when $R$. was home on leave H. H. said to him :

"I am always very glad to get your letters, but I notice you never tell me anything of interest about the Navy."

"No, thank you," replied the small midshipman, " too many of our fellows have had their careers simply ruined by their fathers asking questions in Parliament."

" One day in the Parliamentary calendar," wrote "The Manchester Courier," "is Mr Henniker Heaton's own particular festival-the day on which the Vote for the salary of the Postmaster-General comes up for discussion. In the intervals between the recurrence of these festivals the great mundane movement goes on, apparently unheeded by the member for Canterbury: the House of Commons sees little of him and hears him still less. Irish Land Bills are introduced, Army schemes are agitated, crises in the Far East come and go, but the elect of Canterbury gives no sign. While the world with careless levity permits itself to be distracted by all this multitude of interests, Mr Henniker Heaton keeps his searching 


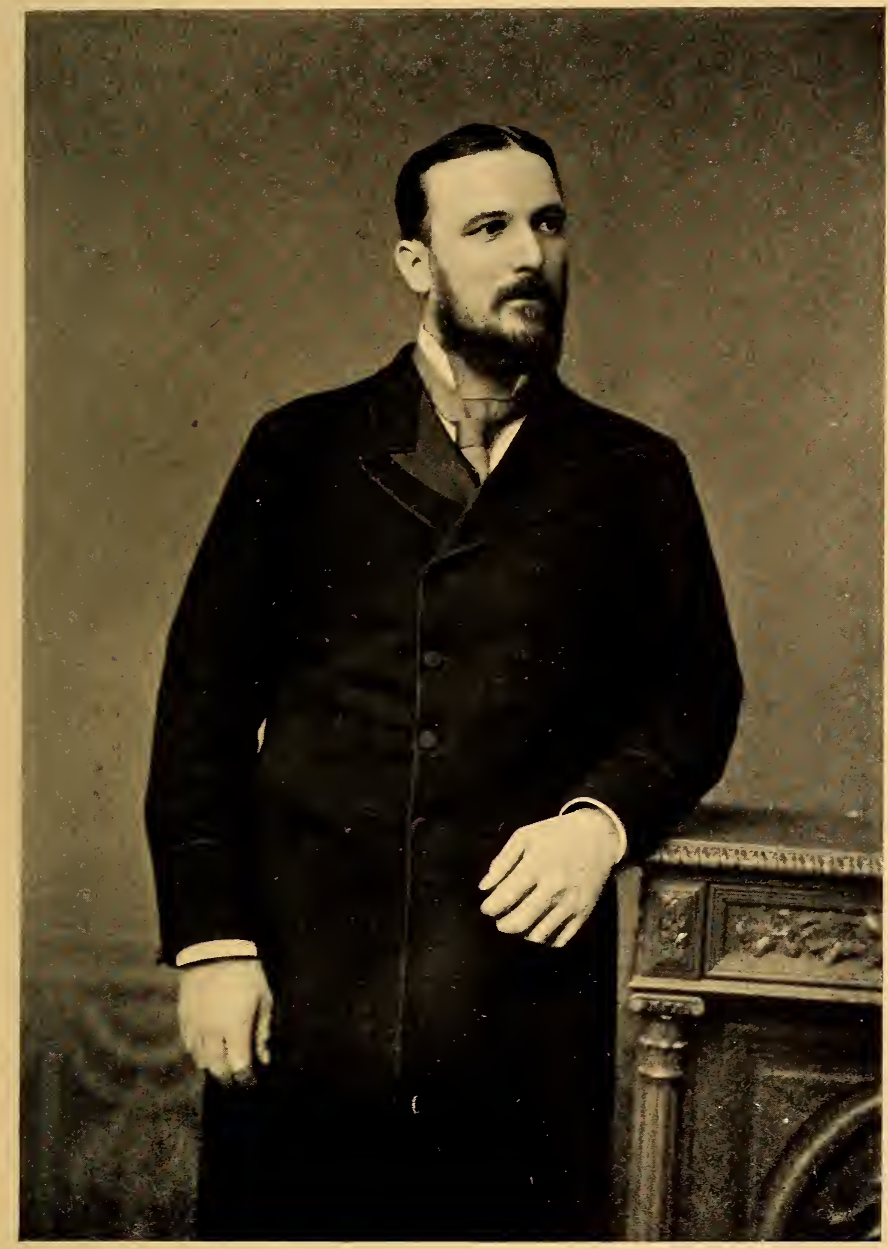

H.H. (AGEN 36) WHEN HE FIRST ENTERED PARLIAMENT 

gaze fixed upon the goings out and the comings in of the Postmaster-General. Nothing happens at St Martins-le-Grand but he hath note of it. Nay, that is ludicrously to understate the case. Nothing happens in the smallest post office of the most remote and obscure township of the whole Empire but Mr Henniker Heaton hears of it, and duly enters the circumstances in his inexorable record. He collects grievances as another man collects postage stamps or pictorial post cards ; he has a museum of them, and his supremest satisfaction in life is to display his collection to the House of Commons and to dilate with affectionate pride on the rarer and more curious specimens."

When $\mathrm{H}$. H. entered the House, there were more men of "light and leading" than in any previous Victorian Parliament.

On the Government benches, were Sir Michael Hicks Beach, W. H. Smith, Goschen, Balfour, Lord Randolph Churchill, Sir Richard Webster, Sir Edward Clarke, J. P. B. Robertson, Colonel Saunderson, Lord Charles Beresford, Sir John Gorst, and Sir Richard Temple.

On the Opposition side, Gladstone, Chamberlain, Bright, Sir William Harcourt, Parnell, Bradlaugh, Sir Charles Russell, Frank Lockwood, Right Hon. A. W. Peel (the Speaker), and Sir Robert Peel.

The remarkable sight was seen of four brothers being sworn in simultaneously: Lords George, Claude, Frederick, and Ernest Hamilton.

The early years of H. H.'s parliamentary life were memorable for the struggle that surged round the Home Rule question, the close divisions and fierce debates when the House sat all night.

Whatever the supporters of Home Rule may feel, the withdrawal of the Irish Members from 
Westminster will deprive the House of much of its interest and colour.

Parnell and H. H. were on friendly terms. "Unknown and unknowable, trusting least those on whom he most depends, he rules Ireland by the absence of every quality usually attributed to Irishmen."

From Kilmainham, Parnell frequently wrote to H. H. saying that a firmer alliance could be made with the Conservative Party on educational and religious questions than with the Liberal Party; and at one time Parnell worked hard to make what he called " business" terms with the Conservatives.

Parnell's powers of detachment were remarkable. He came into the House one afternoon when the fiercest excitement prevailed, regarding the publication by "The Times" of the forged letters.

In a short speech, he denied the authorship of the letters, and then walking into the Lobby engaged H. H. in earnest conversation. Every one thought he was speaking of the political event then stirring men's minds-in reality this is what Parnell said :

"I have just read in the afternoon paper that a mountain of gold has been discovered in Western Australia and that some tons of the specimens have been sent home to you."

H. H. replied that it was true, and gave Parnell about a wineglassful of the " crushing." $\mathrm{He}$ took it away with him, and to the bewilderment of his party no one saw him for a week, and very few indeed knew his address. On that day week, almost at the same hour, he again appeared in the lobby. Walking up to $\mathrm{H}$. $\mathrm{H}$. he said, smilingly :

"I have analysed the specimens, and they go thirty-two ounces of gold to the ton." H. H. said 
he was wrong. Parnell then took from his pocket, a scrap of paper and read "twenty-seven ounces of gold and five ounces of silver." H. H. replied that this was indeed remarkable, for it exactly coincided with the analysis of Messrs Johnson, Matthey \& Co., the famous metallurgists. Parnell then showed the small pin's point of gold he had obtained to $\mathrm{H}$. $\mathrm{H}$. who expressed surprise at his work.

"The fact is," said Parnell, "I take an interest in the matter. I have a small workshop to test the minerals in the mountains of Wicklow, some portion of which I own."

While his hundred of thousands of adherents were fulminating against "The Times," he was quietly working away testing minerals in his laboratory!

Among the many famous men who sat in the House when $\mathrm{H}$. $\mathrm{H}$. first entered it, there was perhaps none who made a more vivid impression on his mind than Lord Randolph Churchill. The following letter, marked " Private," was written in the summer of 1887 , after his meteoric and disastrous resignation, when the estrangement from his recent colleagues was still wide and unbridged:

Dear Mr Henniker Heaton,

"I am not able to make speeches in the country without having given to them beforehand several hours of thought. Now how can I find this time just now?

The study and work necessary to make the Army and Navy Estimates Committee useful absorbs all my time. Further the $* * *$ and Co. lot have behaved so infamously to me, that I cannot bring myself to speak in any part of the country where they may be benefited by my so speaking. When times are more propitious, which they may be possibly 
before very long, it would give me great pleasure to address your constituents at Canterbury. In the meantime I pray a little patience.

Yours very truly,

RANDOLPH S. CHURCHILL.

"The sooner the Tories learn that the combination Salisbury, Goschen, and Smith is useless for election purposes, the sooner their defeats will come to an end."

One evening $\mathrm{H}$. $\mathrm{H}$. was dining with Lord Randolph Churchill when the latter was in a mood half-pessimistic, half-playful. Their wants were attended to by an old waiter called Brown, a well-known character in the Member's Dining-Room.

"Ah, well," said Lord Randolph, "it's a great comfort to feel that when I die I can at least be sure that Brown will put a wreath on my grave."

"With the greatest of pleasure, my lord," replied the faithful Brown, stepping forward with a low bow.

It was Lord Randolph Churchill who performed the feat - and thereby won a wager - of running across Westminster Bridge while Big Ben was striking twelve. H. H. was among those who knew Lord Randolph at the zenith of his power and political fame, and none of Lord Randolph's friends grieved more genuinely when the tide turned.

There was one memorable evening when he was speaking in the House. His voice grew husky and the Chancellor of the Exchequer, turned to a new and totally obscure member with the request:

"Would it compromise you to get me a glass of water?"

The satirical note belying the apparent humility of the request could hardly pass unnoticed. 


\section{AS MEMBER IN THE HOUSE}

At this time Gladstone, though in Opposition, was the most interesting personality in the House, and every story about him was treasured up and passed from mouth to mouth.

Some one once wished to know where Gladstone was to be found.

" Oh," was the reply, "Gladstone has gone to the provinces, to explain the difference between Eternal and Everlasting."

Rigorous in maintaining the rules of the House, Gladstone would never overlook the slightest infringement on the part of any member. One quiet summer evening when the House was almost empty H. H. found himself sitting next Admiral Sir Edward Commerell. His attention was attracted by Gladstone sitting on the front Opposition bench frowning with every sign of annoyance. As Sir Edward did not stir, Gladstone rose and went up to the Speaker.

The Serjeant-at-Arms then approached Sir Edward, and told him that he was out of order as at least one foot should be resting on the floor of the House. Sir Edward had one foot curled up under him, and the other partly on the bench, a grave breach of order. The House laughed, but Gladstone had shown the members a rule and carried his point. His instinctive Conservatism had asserted itself.

Although opposed in politics, H. H. always spoke of "the honour of having sat in the House with Gladstone." Among his papers there is a letter, dated February Ioth, I89I, from Gladstone in reply to a message of condolence.

Dear Mr Henniker Heaton,

I thank you heartily, and I know that in thanking you I thank many. In a great affliction, a most 
heavy loss, God has been most kind to us, and so has man.

Be assured I had never dreamed that barriers erected by the necessities of politics would check the flow of human sympathy within your walls.

With every good wish,

I remain,

Faithfully yours,

W. E. Gladstone.

Early in his political life H. H. was presented to Lady Salisbury, by the late Lord Salisbury, as " a supporter of mine who is engaged in sticking the Empire together with a penny stamp." At the same time Lord Salisbury went on to say that when he visited Australia twenty-six years before he had brought home some young Australian gum-trees, which were then flourishing in the home of his nephew, Arthur Balfour, at Whittingehame.

There was a certain young Welsh Member who made a rather striking speech in the House one day. H. H. stopped him in the Lobby to congratulate him. Many years later Mr Lloyd George surprised $\mathrm{H}$. $\mathrm{H}$. by recalling the incident, adding :

"You were the first Tory Member who ever said an ercouraging word to me, and I have never forgotten it."

A tragic occurrence once took place in the House of which $\mathrm{H}$. H. was a witness. $\mathrm{H}$. $\mathrm{H}$. was sitting in the gallery with Kitchener listening to a debate on a public grant of money for the hero of Omdurman. A member rose to oppose the motion. While speaking his voice became unsteady, and his hands lost their power. Brandy was brought to him. He sat down for an instant and then rose again to resume his speech. 
He dropped the glass of brandy and fell into the arms of some fellow-members. He was carried out to the back of the Speaker's chair and died a few hours later. This was Mr Wallace, one of the members for Edinburgh, who made an immense but short-lived reputation in the House by his witty and audacious speeches.

From the commencement, H. H. was an advocate of votes being given to women of property, and he was one of the backers of the Conciliation Bill. $\mathrm{He}$ was totally opposed to Militancy, and thought with many others that the women's cause was seriously injured by its adoption. H. H. was one day attending a banquet at the Guildhall when one of the beautiful stained glass windows was broken by a suffragette. Some splinters of glass fell upon him, slightly cutting his head. Christabel Pankhurst made the amende honorable by a charming letter of apology.

After a demonstration made in the House of Commons, it became necessary to close the Ladies' Gallery to all except personal relatives of honourable Members, who were responsible for their good behaviour. The closing of the Gallery entailed much hardship on many women genuinely interested in politics, who were thus debarred from listening to debates.

Many were the devices adopted by obliging members to establish "cousinships" with their fair friends who wanted tickets for the Ladies' Gallery. The most ingenuous excuse offered in exculpation was that of $\mathrm{Mr}$ Dudley Ward, the good-looking young member for Southampton, who explained gravely that both his guests had promised to be sisters to him.

It was impossible to be with $\mathrm{H}$. $\mathrm{H}$. in the House without realizing how deeply he loved every stone 
in the building, and what pride he felt in its glorious traditions. He was never tired of showing his friends over the beautiful old hall and the little chapel in the crypt, where his grandson, Peter Joseph Henniker Heaton, was christened.

The great stretch of water seen from the Terrace, with the old Palace of Lambeth across the way, held for him a never failing charm. In brief, he enjoyed every moment he spent in the House, and when he left he carried away recollections of a lifetime's happiness.

H. H. was a very regular attendant at the debates and could be relied on to be in his place when wanted for a snap division-a condition that requires more self-sacrifice than is usually credited to members.

There was one summer when the whips of both parties were on the alert to prevent any accidents happening, and on one occasion men were stationed outside the church where Sir Charles Cayzer's daughter was being married to Captain Madden-now Admiral Madden-to catch the members as they came out of church and send them back post haste to the Commons.

Mr Birrell's plaintive voice found an echo in the breast of many honourable Members when he spoke to his Bath audience:

"I may inadvertently have gone home for dinner occasionally; but, gentlemen, when you have to choose between an angry whip and an angry wife___? "

During his parliamentary career $\mathrm{H}$. H. made several attempts to get the Whips to give members credit for attendance to their duties when paired, but he could never convince them that a pair is as effective as a vote.

A pair does not produce the impressive effect on 
the Opposition of the member voting. The strikingout of equal values from opposed quantities may be convenient in arithmetical or algebraic calculations; but the zealous Whip loves to march his entire force on to the ground; and is sometimes inexorable.

Sir Richard Webster-afterwards Lord Alverstone - used to tell a story of a pair having been effected by the Whips on a critical occasion. For conscience' sake-after the division-Whip No. I said to Whip No. 2 :

"I think I ought in justice to explain that my Member broke his leg this afternoon and so could not attend."

"Infamous," said No. 2. "I will forgive you, but only because my man whom I paired with your man is dead."

A description of life in the House of Commons written by $\mathrm{H}$. H. may be included here :

"The House of Commons is at once the easiest and most difficult assembly in the world to understand and in which to transact business.

"The ambitious young member, consumed with burning zeal to distinguish himself, will probably commit a dozen breaches of order within the first month. He will walk to his seat while a member two benches above him is speaking, and interpose his presence between the orator and the Speaker. This is a gross breach of order, and the older members will shout indignantly their disapproval, and call 'order,' 'order.' He will ask his question from one of the seats on the cross benches, technically 'outside the bar.' This is another gross breach of order at which his fellow-members will shout disapproval ; and after the bewildered man is at last made to understand, he comes in, and a friendly M.P. resigns a temporary 
place from which he may address the House. He will keep his hat on when standing at the bar, though the rule is that he can only wear his hat when seated in the Chamber. He will read a newspaper in the House. This is-as in the courts of law-another gross breach of order, and brings down on him the censure of the Speaker. He will in his first speech insist on addressing the M.P.'s and say 'Gentlemen,' in place of ignoring his fellow-members, and addressing his remarks to Mr Speaker, or simply saying ' Sir.' He will mention the previous speaker's name instead of the Member's constituency. He will greatly offend his fellow-members in his burning desire to carry his resolution by lecturing them, and reminding them of their promises to their constituents at the general election. He will be called to order for not strictly confining himself to the subject; for instance, in speaking on the Navy estimates, he will give a general survey of its deficiencies when the question is the pay of the men ; or he will speak on the Post Office vote when the Telegraph service is under discussion; or on mismanagement in the War Office when the equipment of volunteers is being discussed.

"The rules for framing questions are very strict. They must not involve (I) argument, (2) opinion, (3) inference, (4) imputation, (5) irony, or (6) hypothetical cases.

"Answers to awkward questions are cleverly prepared by the expert officials, and the oldest Parliamentary hand often finds it impossible to get satisfaction. A Minister has been known to have prepared for him three different replies on a question of fact.

"The common way of showing resentment to the Minister who gives an unsatisfactory or sharp answer to a question is for the aggrieved member to rise at once and make a formal speech. ' $\mathrm{Mr}$ Speaker, in consequence of the unsatisfactory answer, I beg to give notice that in the estimates I will call attention 
to the matter and move that the salary of the Secretary of State for War be reduced by $£$ Ioo.'

"One of the most eloquent yet least trustworthy of our politicians made a series of charges against a dull but straightforward Front Bench leader. The attack was skilfully arranged, under four heads, and left a very unpleasant feeling in the public mind. The old politician rose, and roughly but clearly struggled through and satisfactorily replied to three of the charges. Then he became confused. He looked over and over again through his papers, and turned them upside down. In desperation he turned to his audience and said: 'Now, in regard to the fourth charge, I know there is an answer to it, and a complete answer to it. I ask the House of Commons to believe me, although I cannot find the answer now.' The very sincerity of the speaker evoked the sympathy and goodwill of hon. Members, and they cheered and cheered again, to the utter discomfiture of the glib but unscrupulous opponent. It is not merely the words, but the stored-up reputation of an orator that tell. As Addison said, apologizing for his limited conversational powers: "I have but ninepence in ready money, but I can draw for a thousand pounds.'

"The House of Commons is the fairest tribunal in the world and the quickest at measuring a man's capacity. A good story is told of its acumen. The successor of the great Sir Robert Peel, as member for Tamworth, came into the House radiant with the halo and glow of the great man who preceded him. The House immediately discovered wherein lay his exceptional abilities, and they put him on the wine and cigar committee.

"A speech that smells of the oil-lamp is quickly detected and even in some degree resented. The immemorial distrust of forensic ability still characterizes the House. Brougham tells us how a brilliant new member, got up as a squire, impressed the assembly 
until he dropped the fatal phrase 'our circuit,' when he was instantly howled down as an impostor.

"The House is impatient of bores, and the process of calling ' divide, divide, 'vide, 'vide!' and 'order, order!' soon extinguishes the most formidable bore. The old members of the House of Commons hastily arrange with each other to put down a bore by a concentric crossfire, one side calling ' divide, divide!' and the other 'order, order, question, question!' The effect is striking and conclusive."

On one occasion, an interminable bore was annoying the House and preventing business. H. H. moved " that the honourable gentleman be no longer heard." The Speaker rose with great dignity and declined to put his motion, but he added these significant words: "I must, however, warn the hon. Member that he is trifling with the time of the House, and if he persists it will be necessary to take some decisive action." The Speaker told H. H. afterwards that only in the case of an attack on the ambassador of a foreign Power would such a motion as he proposed be permitted. On the same occasion he admitted that one can use very strong language if properly selected in the House.

The man who comes into the House of Commons without any fixed views, but who is determined to distinguish himself by taking part in every debate, often ruins his reputation in the first few months, and is never again listened to.

H. H. knew a member who made his maiden speech within an hour of entering the House.

On the other hand, during the first seventeen years H. H. was in Parliament, Mr W. W. Beachthe father of the House of Commons-never once 
spoke, yet his views and opinions privately expressed carried considerable weight.

An amusing incident happened to $\mathrm{H}$. $\mathrm{H}$. one day. $\mathrm{He}$ was hurrying through the Lobby when he was stopped by one of the Junior Whips, Lord Balcarres, who asked him to oblige him by putting a blocking motion. H. H. read the paper and exclaimed :

"Well, this beats everything! you are asking me to block my own amendment!"

Lord Balcarres had merely been given the slip of paper by a member of the Government and asked to find a private member to put the motion. Unfortunately, the first person he met had been $\mathrm{H}$. $\mathrm{H}$. When Lord Balcarres realized what he had done he could not help laughing, and it ever afterwards remained an excellent jest between them.

Not the least notable of H. H.'s contemporaries was Henry Labouchère, the famous editor and proprietor of "Truth." Most stories of Labouchère have achieved a world-wide reputation, but $\mathrm{H}$. H. never forgot one night when Labouchère kept every one enthralled with his reminiscences. Labouchère was popularly supposed to be a hard man-a reputation that was perhaps one secret of his success. He related an experience he had had in Russia when playing cards with some Russian friends. An officer present lost a considerable sum of money to Labouchère, and he called on him the next morning in a great state of emotion to explain that he was absolutely at the end of his resources and could not possibly pay. Would Labouchère take pity on a young officer whose whole career was threatened with ruin and let him off the debt? Labouchère replied politely that he would do nothing of the sort. In vain the 
young officer entreated and implored. Labouchère was adamant, and his visitor left vowing he was a ruined man.

A few hours later a weeping woman, accompanied by two sobbing children, was shown in. The young wife threw herself on her knees and begged Labouchère to forgive her husband's debt, as he had not got the money and threatened to commit suicide-she would be left a widow, her children fatherless. Labouchère remained unmoved, and explained he could under no circumstances overlook the debt. Early the next morning the Russian officer, looking wild and haggard, strode into Labouchère's office. "I am a dead man," he said, " and my blood is on your head. I have not the money to pay you and I cannot face the disgrace." He pulled a loaded pistol from his pocket and held it at his head. Still Labouchère made no move. The Russian then said, "I shall count ten slowly and if you do not alter your decision, you will be to all intents a murderer. One-two-three -four-five-six." At "six" Labouchère produced a cigar and lighted it. "Seven-eight-nine-ten." At the word "ten" the Russian plunged his left hand into his coat and dashed down a pocketbook with bank notes for the full amount due. "Ten thousand curses on you, cold-blooded Englishman," he shouted, as he flung himself from the room.

"I knew he was lying from the first," explained Labouchère blandly.

H. H., like many another onlooker, saw much of the game. The courtesies of the House never lost their interest for him. When the word is passed that a new Member has risen for his maiden speech, the members will come trooping in to give him an 
opportunity of proving his worth. Extraordinary patience will be shown to an old and respected member evidently suffering from old age and its attendant verbosity, or a friendly sympathetic "hear, hear" will often encourage some unfortunate speaker who has broken down from nervousness.

There was once a luckless member who got as far as a dramatic "There is one thing England will never forget," and here his memory failed him. "There is one thing, Mr Speaker, England will never forget___"

The House waited in vain, but after a few seconds' deep pondering the Member abruptly sat down. Later on in the Lobby some sympathizers crowded round him.

"By the way, what was it that England will never forget?" they asked.

"I'm d-d if I know!" he answered.

$\mathrm{H}$. H. was often asked which of the members in his opinion enjoyed the greatest amount of personal popularity in the House. He thought this honour undoubtedly belonged to $\mathrm{Mr}$ Lewis Harcourt, and as a proof of this he would cite the occasion when $\mathrm{Mr}$ Harcourt entered the House for the first time after his marriage. The entire House, Unionists, Liberals, Irish, and Labour, rose to cheer him as they had not cheered for many a long day.

For many years Rotherhithe sent to Parliament Mr Cumming Macdona as their representative. His correct designation in the House was The Honourable Learned, Gallant, and Reverend Member for. Rotherhithe, having been at different times in his career a clergyman, a barrister, and a soldier. He was one of the old Tory party who fell in the debacle of 1906. His election posters were headed "I will follow 
Balfour," a prognostication that proved unfortunately only too true. Like many others his defeat was a great blow to him, and, although he fell in good company, he did not long survive a bitter disappointment coming late in life. With his disappearance the House lost a genial personality, popular on both sides. Some amusing verses were written by $\mathrm{Mr}$ Harrison Hill which appeared under the title :

\section{"HOW WE PASSED THE ARMY ESTIMATES"}

"In the House of Commons dining-room four men were dining well (With intervals for exercise at each Division bell), And Henniker Heaton was the host, a genial host was he, And Harrison Hill the humorist was Heaton's vis-à-vis. That's two H. H.'s opposite (I speak in fides bona) And Frankfort Moore the novelist sat opposite Macdona, The Honourable, Reverend, Learned, Gallant man of larks, Who sits so blithe for Rotherhithe, when he ought to sit for Barks. Two M's, two H's opposite, and two of them M.P.

And two of them were visitors, and two were vis-à-vis. We talked Imperial Postage, and G.G. Clubs, ${ }^{1}$ and dogs, Of Marriage Acts, and derelicts that float about in fogs. We talked of many subjects, and in every kind of tone, But we left the Army Estimates religiously alone, Except for the Division bell, when each man quenched his drouth, And toddled off and voted with an entrée in his mouth. But Heaton told Macdona he thought it most unfair That though there was a pair of them they couldn't even pair. And every time the waiter would fresh delicacies bring That wretched old Division bell would give another ring. Then we went into the smoke-room for a coffee and cigar Which the waiter went and brought us from the House of Commons bar, Till Heaton and Macdona, when the stars began to peep, Said they'd have a dose of Estimates, which meant a dose of sleep. Then a novelist and humorist stole through the Commons door, For they heard a Member speaking and two other Members snore; But Heaton and Macdona were wide awake you'll guess, When the House adjourned at midnight for the Whitsuntide recess."

1 Gay. Golfers' Club, of which Mr Macdona was President. 
In all H. H.'s measures for promoting Imperial Penny Postage, he received warm support from Lord Charles Beresford, who foresaw the imperative necessity of drawing the Colonies closer to the Mother Country, at a time when hardly anyone could be found to take the matter seriously. In Lord Charles Beresford's memoirs he writes:

"At Christmas, I898, Mr Henniker Heaton's indomitable perseverance had resulted in the establishment of Penny Postage in every part of the British Empire except Australia and New Zealand. Lord Randolph Churchill and myself were hearty supporters of Henniker Heaton, who gave to each of us a golden penny in commemoration of the event."

An interesting letter from Lord Charles Beresford, written on board H.M.S. " Bulwark," at Lagos Bay, in I906, may here be included :

My dear Henniker Heaton,

Thank you for your most interesting letter of the 7 th. You richly deserve all the grateful appreciation which your countrymen show you on every possible occasion. Well done, indeed well done. You are one of the forlorn hopes of the Conservative Party, and all your friends will be delighted that you have been again returned to Parliament, not only for your own sake, but for the sake of the country, and those splendid and brilliant reforms you have unvaryingly pushed for and won for the Line of Communication by Post.

I told Balfour, before I left, that I thought the Liberal Party would come in far greater numbers than was anticipated, and that they would be in far longer than was anticipated, but I never imagined the slump would be so terrific. 
There are many reasons and causes for the tremendous Liberal majority. Raid.

I. The iniquitous and dishonourable Jameson

2. The mismanaged South African War.

3. The large consensus of opinion that the War was in the interests of the Jews, and also the chaotic state of the Army.

4. The dread of the working classes of anything in the way of Protection.

5. Mr Chamberlain's Policy of having joined together, on one platform, Skilled and Unskilled Labour for the first time since their enfranchisement.

6 . The inability of a large number of gentlemen to work on the old lines of Patriotism, instead of for Personal motives.

7. The last Government having held on to Office too long. It was quite apparent that the country wished for a change, and there were other minor matters which helped to make the great smash.

For my own part, I do not think that the Gentlemen will ever again be in the predominant position of power in the Government of our great Empire. Old ideas, issues, and Party lines will disappear. The leisured classes will no longer supply men to work unselfishly from solely patriotic motives. Politics will become a Profession, and Politicians will be paid. The demarcation will be between the lines of Capital and Labour as time goes on. Working men will be returned in larger numbers at each election. This is my forecast. Personally, I have no great fear for the future.

I have absolute belief in the common sense, patriotism, and right feeling of the people; and if we read history, we shall see that the people were always right in the end.

Bannerman is the most powerful Minister we have had, and I am confident that, with the great majority 
the Liberals have had, his Government will be reasonable.

From a Party and Strategical point of view, I believe it madness to have adopted the Fiscal Reform programme, after the unquestionable reverse it had in the hands of the people at the last Election. I never believed myself in Protection, and think $\mathrm{Mr}$ Chamberlain in his saner moments was more correct in his diagnosis than he is now, when he remarked that "Protection, if ever brought in, would make the rich richer, and the poor poorer."

Yours very sincerely,

ChARles BEREsford.

Once and once only during his parliamentary career $\mathrm{H}$. H. crossed swords with the War Office, and succeeded in hacking his way through the barricades of red-tape until he reached head-quarters, where the enemy capitulated. The facts were these. A lady wrote to $\mathrm{H}$. H. to tell him that her son at Harrow had been ploughed for the Army, and asking him to use his influence on his behalf. The boy in question was captain of the cricket eleven at Harrow and devoted to all sport, a born leader and one of the most popular boys in the school. The sole fact that R. was captain of the Harrow eleven was sufficient for H. H.-as undoubtedly it would have been for the Duke of Wellington!

The correspondence between $\mathrm{H}$. $\mathrm{H}$. and the War Office, were it permissible to publish it, would make good reading. There could only be one end to such a combat and $\mathrm{R}$. is now a major in the - Hussars. In the course of championing the claims of his young friend, $\mathrm{H} . \mathrm{H}$. had an interview with a very important bigwig :

"Look here, Henniker Heaton," said General c 
Sir W- _ " " examinations are all nonsense. When I joined the Army forty years ago the test they set us was to say the Lord's Prayer and to write our own name-and by the Lord Harry I was plucked the first time!"

H. H. was the first to introduce tea on the Terrace, which became almost at once a popular feature of London social life. The photographs taken by the late Sir Benjamin Stone made a permanent record of some of the most interesting of these gatherings. On the Terrace of the House H. H. had the pleasure of introducing his great friend, the late Sir Charles Gavan Duffy, to Sir Edward Carson, where they had a deeply interesting discussion on the affairs of Ireland. Sir Edward Carson ended the interview by saying if all Irishmen were like Sir Charles he would gladly consent to Home Rule for Ireland.

"And ut's Carrson that has the soft spache wid him," commented an Irish Member hearing the story.

The following letter was written by Sir Charles, from Nice :

\section{My dEAR Heaton,}

I am reading with considerable enjoyment the volume of political gossip you sent me. I entered parliament at the same date as Sir William Fraser and am familiar with the men and events he deals with. The book would be a great deal better if it were written in strictly chronological order, and about half the size, excluding all anecdotes which are not new, or are not pointed.

I never waited the meeting of parliament with so much anxiety. The G.O.M. has a very difficult task, but his safety lies in courage. If he prepares a thoroughly satisfactory measure he will content Ireland, even if it should be lost for a time in the Lords, 
but if it should be a paltry scheme his career will end in a London fog. . . .

Apropos of fogs, I hope Mrs Heaton is facing the winter courageously. We have had very satisfactory weather since you have been here with the interval of a day or two. In France we are in some danger of a general overturn. The leading men of the republic who have held the government for twenty years are all suspected of complicity with corruption and of plundering the savings of the industrious classes invested in the Panama Canal.

If you send me a copy of Gladstone's bill as early as you can, it will be very welcome.

I notice that Ritchie met the fate you predicted, but it is doubtful policy in Lord Salisbury to allow his son to spoil the career of one of his colleagues.

My daughters join in kindest remembrances to Mrs Heaton.

Very faithfully yours,

C. Gavan Duffy.

During the twenty-six years $\mathrm{H}$. H. sat in Parliament he saw many changes, and very few of the original members of his first Parliament were left by the time he retired.

Some interesting letters from old Parliamentary colleagues may here be included. Lord Curzon wrote, from Viceregal Lodge, Simla, on May 9th, I90I :

\section{Dear Henniker Heaton,}

I was much gratified at receiving your letter, and at learning that I am not quite forgotten at home. I follow these struggles of Sassoon and yourself with much interest. In these contests the ultimate result is quite certain. But it often takes a long time. I am glad to notice that in the midst of Parliamentary labours you find time to lend an ear to the whispers of society talk, and to repeat them for my edification 
across the seas. Here we are so respectable that we have to depend upon England for our gossip.

Yours very truly,

CURzon.

In I906, Mr James Bryce, afterwards Lord Bryce, on being appointed British Ambassador to the United States, wrote :

Dear Henniker Heaton,

Thank you heartily for the kind words you have sent me, nothing could have given me more pleasure than your assurance that I have none but well wishers on your side of the House in the responsible task I am undertaking. It is a great wrench to leave the House of Commons after 27 years, but the sense of parting is softened and sweetened by the recollection of all the kindness one has met with there.

If I can be an instrument in doing anything to help you in the great enterprise of cheapening Transatlantic post, it will be done gladly.

Believe me,

$$
\begin{gathered}
\text { Very truly yours, } \\
\text { JAMES BRYCE. }
\end{gathered}
$$

Sir William Harcourt sent the following letter, from Malwood, Lyndhurst, on July 6th, I899:

My dear Henniker Heaton,

Your kind and generous letter has given me sincere pleasure. It has always been my first ambition, in whatever situation I found myself, to stand well with the whole House of Commons and to do what seemed to me best for the interests of that great Assembly, which is the true representation of a great people. If I have been able to earn the good will of my opponents as well as my friends I shall have succeeded beyond my hopes, and such a result is a 
high testimony to the noble tone of public life which I rejoice to know governs all our Party conflicts. I have seen with great pleasure the signal success of your enlightened and beneficent efforts in Postal Reform, in which you have made a name which will not be forgotten. If I have contributed to support you in any slight degree I shall be proud to pursue your triumph and partake the gale.

Yours very truly,

W. V. Harcourt.

The time came at last when $\mathrm{H}$. H. also left the House of Commons, where he had spent so many happy years. Of the twenty-six years in which he represented Canterbury, during twenty-one he was unopposed. He fought altogether three elections, and retired in Igro, when a farewell banquet was given in his honour.

The words of the historian Justin M'Carthy may fitly bring to an end this chapter in the life of $\mathrm{H}$. H. :

My dear Henniker Heaton,

I have heard, of course, as everybody has, the announcement that with the close of this Parliament you have made up your mind to retire from your public or at all events from your Parliamentary life. The news came with quite a shock of surprise to me, for I had never regarded you as one whose career of active work must be drawing to its close. Few men living anywhere in the world can have rendered more beneficent, or indeed so many beneficent public services as you have rendered not merely to your own people but to all the peoples within the range and reach, or striving to come within the range and reach of civilization. I cannot think but that you will find a certain sense of vacuity when you have withdrawn from that House of Commons in which you found so 
congenial, so characteristic, and so nobly active a career, and where you had friendship, sympathy, gratitude and encouragement from all your fellowmembers, of whom I had the honour and the pleasure of being one during many years. Still I must say, of course, that, if you feel you are taking the right decision, you are the man whose decision ought to settle the question in the minds of all who know you as I do. My heart is filled with gratitude to you for most valuable services rendered to me at a time when broken health and other troubles made the friendship and the support of men like you a very shelter against the storm. Forgive me, therefore, if I do not write more cheerfully on this coming event in your life of public and private benefaction.

Pray forgive me for addressing you through the mechanism of the typewriting machine. The truth is that for several years past my sight has been so weak that I have been unable to use the pen for anything much beyond a mere signature.

Ever your true friend, JUSTIN M'CARTHY. 


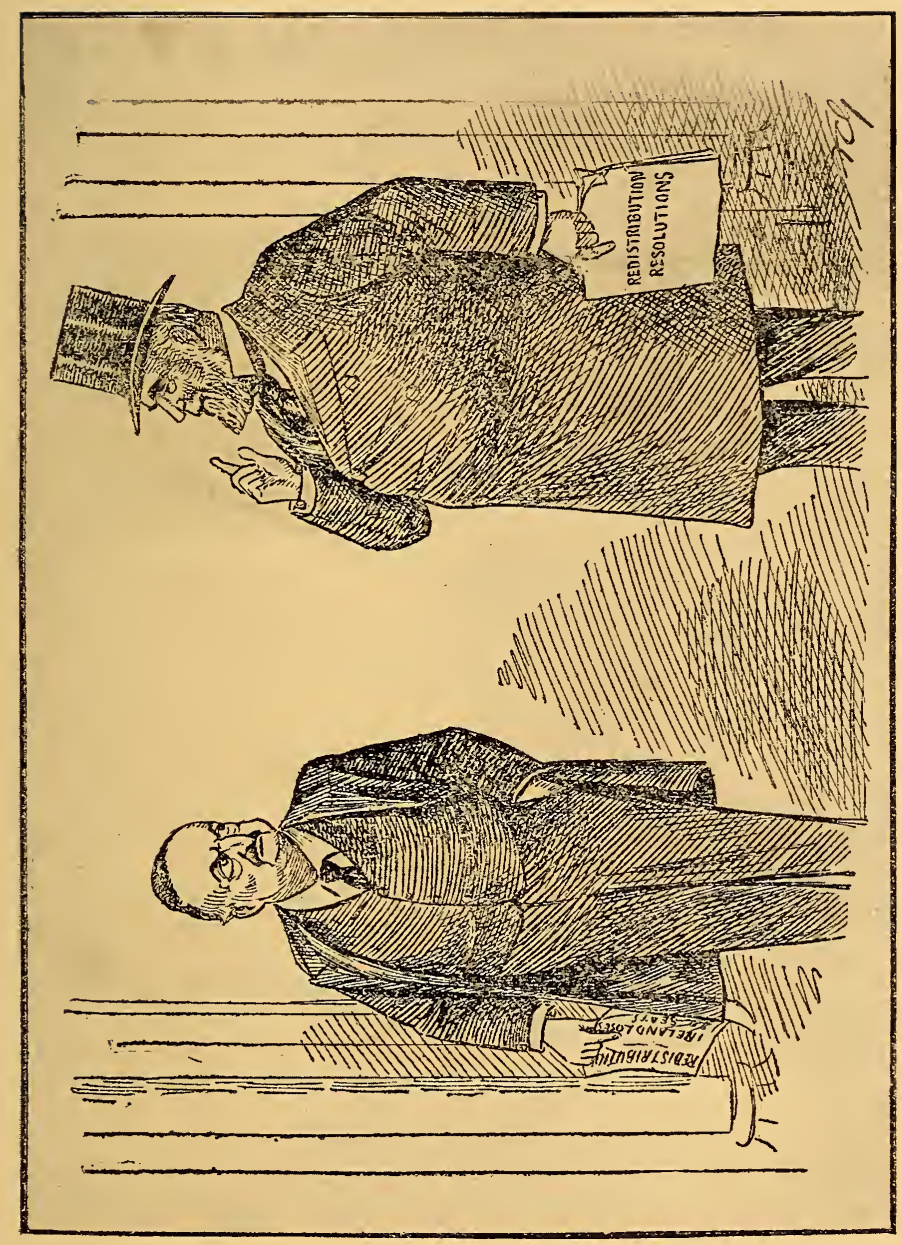

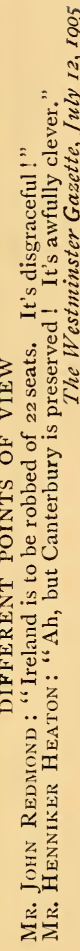





\section{CHAPTER III}

\section{AS MEMBER FOR CANTERBURY}

\section{In the Constituency}

70 call Canterbury a Conservative stronghold is to do it no more than justice. Whether or not, after every General Election, Kent can claim the title of "Solid Kent," it will invariably be found that Canterbury has done its part in returning a Tory representative to Westminster. The preponderance of Toryism in the borough was best illustrated in I9Io when, with an equally split Conservative vote, the Liberal candidate was in a minority of 500 .

$\mathrm{H}$. H. was justly proud of his long connection with Canterbury. The presentation of the Freedom of the City in I899 was an honour he deeply appreciated. The beautiful Casket containing the document was made from Cathedral Oak, ornamented with emblems of the various countries which had joined in Imperial Penny Postage. The presentation was made by the Mayor, Sir George Collard, and the Archbishop of Canterbury (Archbishop Temple) gave the congratulatory address.

On September I7th, I904, Mr Joseph Chamberlain wrote to $\mathrm{H}$. H. as follows :

Dear Mr Henniker Heaton,

I have heard with great pleasure that you have again been requested by the Unionist Committee to 
represent Canterbury in the next Parliament, and I am delighted that you should find yourself able once more to bear the burden and to render further service to the country and the Unionist cause.

You can look back with satisfaction to your past efforts. It has been given to few men to promote reforms independently and to see them adopted in their own lifetime with universal approval. I take special pleasure in the certainty of your return, as I know how warmly you appreciate the importance of drawing the different parts of the Empire more closely together. You have a wide knowledge of colonial conditions, and your support to the policy I have endearoured to recommend to my countrymen will be of great value.

$$
\begin{aligned}
& \text { With all good wishes, } \\
& \text { Believe me, } \\
& \text { Yours very truly, } \\
& \text { J. CHAMBERLAIN. }
\end{aligned}
$$

In the early days the Conservative party in Canterbury was led by Captain Thomas Lambert, a true Tory of the old school. His charming hospitality and the wonderful roses from his gardens made a fragrant memory not soon forgotton. His death was mourned by all the county.

Dean Wace, writing to $H$. H., said, "You must have felt deeply the death of our venerable friend Captain Lambert. He was a true English gentleman."

Other loyal friends of those old days were Edward Plummer, Sir George Collard, Walter Furley, and lastly Dr Frank Wacher, of whom it might truly be written :

\section{"Of soul sincere}

In action faithful, and in honour clear,

Who broke no promise, served no private end." 
H. H. delighted in all things Kentish. "My Cathedral," "My Archbishop," were frequently on his lips, and he thoroughly enjoyed the run down to Canterbury through Kentish hop-gardens and Kentish orchards ; and not least he loved the kindly faces of the Kentish folk with their slow, old-fashioned speech.

In springtime the woods around Canterbury are a very heaven of green and gold. On Primrose Day a great hamper of yellow primroses was always sent to "Our Member" by two old ladies, Primrose Dames, and the whole house in Eaton Square would be a mass of yellow blooms from Canterbury.

The famous Canterbury Cricket Week was a gathering $\mathrm{H}$. $\mathrm{H}$. never failed to attend. The balls, the theatricals, the luncheons and tea-parties upon the cricket field changed the quiet Cathedral city into the gayest of gay scenes.

H. H., himself a lover of cricket, could never resist the wistful faces of the little urchins who hung around the gate, trying to catch glimpses of their flannelled heroes. Many a time he would send the whole ragged little band rejoicing through the turnpike.

One wonders if any of these were among the bodyguard that dogged H. H.'s every footstep at election time, shouting in husky little voices the popular election song which went to the tune of "Tramp, tramp, tramp, the boys are marching."

"Vote, vote, vote, for Mister 'Eaton, Niver mind a word er wot they si, For 'Eaton is the man And 'e does the best 'e can, etc. etc."

A compliment distinctly qualified, one might consider.

H. H. took a great interest in King's School, Canterbury, and was present whenever possible to 
give away the prizes. It was in mid-ocean in 1907 that he discovered on board ship an Old Boy in $\mathrm{Mr}$ Kennerly Rumford, who, with his wife, Clara Butt, was on his way to tour Australia, and together they dispatched a marconigram to King's School on the occasion of some school festivity.

Like all pocket boroughs, Canterbury was not entirely free from the charges of bribery and corruption. There are alive to this day old men who can recall the happy times when the tables in the Committee Rooms were spread with golden sovereigns, while the sitting Member gazed tactfully out of the window with a pleasant word over his shoulder, "Help yourselves, Gentlemen, help yourselves." The rival candidate wore an overcoat with immense pockets, and it was an understood thing that the free and independent electors who walked on either side of him were at liberty to thrust their hands into the gaping pockets in search of the gold with which they were lined.

Such halcyon days cannot, however, last for ever, and there came an evil hour when the then Member was unseated on petition. As a result of the inquiries, bribery was found to be so widespread that for a period of seven years the ecclesiastical capital of the Empire was disfranchised.

This was the situation at Canterbury when, the seven years being at an end, $\mathrm{H}$. $\mathrm{H}$. was elected as Conservative Member. Needless to say, his party was anxious to avoid any suspicion of bribery, and during the weeks preceding the election Lady $\mathrm{H}$. $\mathrm{H}$. was asked not to allow her servants to buy even half a yard of ribbon in the town.

If, in those days, Canterbury was out of favour 
in the political world, it was unfortunately still more out of favour in Royal circles. Local tradition ascribed this feeling to an incident that occurred when Queen Victoria visited Canterbury with the late King Edward as a baby. One enthusiastic woman stepped forward and planted a kiss on the royal brow of the slumbering infant with a resounding "Bless his little heart." Her Majesty was deeply offended and for many years never again set foot in the city. Great therefore were the rejoicings when in 1897 the Prince and Princess of Wales visited Canterbury and the loyal citizens once again basked in the smiles of royalty.

H. H. frequently took his friends down to Canterbury, knowing how much pleasure and interest they would find in the beautiful old city. Sir Joseph Ward, the late Premier of New Zealand, was among the friends who visited the town, accompanied by the Member. The occasion was the presentation of a flag from the children of Canterbury, New Zealand, to the children of Canterbury, Kent. It was a happy idea, resulting in an exchange of letters between the two places so widely separated, forging one more link between the mother country and her Colonies.

Another welcome visitor was Sir George Reid, the High Commissioner for Australia. H. H.'s friendship with Sir George dated back to the days of early manhood, and knew no diminution throughout the long strenuous years they were both destined to enjoy. On arrival at Canterbury, there was some competition among the various cab-drivers for the privilege of conveying the Member and his distinguished guest to the hotel. This drew forth a reminiscence from Sir George of a similar experience in Australia, when 
he seemed in danger of being torn in pieces by cabdrivers all eager for his patronage. Sir George solved the difficulty by announcing that he had always been in favour of large families, and he would take the cabdriver who had the most children. Spirited "bidding" then began, but was quickly ended by a gruff, "You come along er me, sir, I've got seventeen children." As Sir George was driven off in triumph, even the ranks of Tuscany could scarce forbear to cheer.

Sir George's repartees when on the election platform are quoted all over the world. His slow gentle manner of dealing with hecklers gives an added piquancy to the situation. One evening when he had been enduring with great good humour continuous interruptions, a man rose from the back and shouted :

"You are double-faced."

Sir George Reid considered the man reflectively :

"It is easy to see that gentleman has not two faces, or he would not have come with the one he has tonight."

One May morning $\mathrm{H}$. H. persuaded his friend $\mathrm{Mr}$ John Wanamaker, the late Postmaster-General of America, to leave London's noise and traffic, and spend a few hours in seeing Canterbury and the Kentish orchards in full bloom.

In the train on the way down, Mr Wanamaker learnt from the papers that it was H. H.'s birthday, May I8th, and he at once presented him with his watch as a memento. "When you lose that I will give you another," he said. But the promise had never to be redeemed, for the watch bore a charmed life. It was dropped, and lost and trodden on, and stolen, by a steward on board ship, who subsequently 
jumped over board, and endured every vicissitude of fortune that can befall a watch, and still it kept its excellent undeviating accuracy and became as much a part of H. H.'s apparel as his coat itself ; nor would he have changed it for any other watch in the world.

$\mathrm{Mr}$ Wanamaker and $\mathrm{H}$. H. spent a delightful day at Canterbury, meeting old friends on one side, and making new ones on the other. Just near the Cathedral H. H. stopped to introduce to Mr Wanamaker a young man who was striding along. Mr Wanamaker, as is well known, has a great gift of engaging every one he meets in interesting talk the first moment of acquaintance. The young man found himself describing Canterbury and its industries to a most sympathetic listener. The talk turned on the large breweries in the city. Mr Wanamaker, who is a great temperance advocate, asked his companion:

"Tell me, do you drink?"

" No, I am a teetotaller," replied the young man.

"Shake," said Mr Wanamaker, suiting the action to the words.

"And does your father drink?"

"No, he is also a teetotaller."

Again the hand of fellowship was extended.

"And what is your father's profession?"

"Archbishop of Canterbury," replied young Mr Temple modestly.

The hearty infectious laugh that rang out from Mr Wanamaker made the passers-by turn round. Linking his arm through H. H.'s, Mr Wanamaker said :

"Why, this is enough to get you unseated-why didn't you tell me your friend was the son of your Archbishop?" 
Mr Wanamaker's keen sense of humour, combined as it is with the truest love for humanity, has made him friends from one end of the hemisphere to the other. At luncheon subsequently with the Archbishop a seal was set upon a day full of happy associations.

There is an interesting letter from Archbishop Benson, dated I5th February I892, in reply to a note from $\mathrm{H}$. $\mathrm{H}$. asking his opinion as to the propriety of speaking in Newcastle on a Sunday in connection with postal matters:

\section{My DEAR Mr Heaton,}

Thank you much for your kind confidence.

I think it would create much adverse feeling if you lectured on Sunday on a subject so purely secular, although so serviceable. Many of those who would otherwise be your best and most amenable auditors would be scandalized. You could on a weekday evening command not only as large, but larger masses of thoughtful men, because you would add to them a highly respectable and thinking set who would certainly not come on Sunday. They would in fact be set against the plan itself, as hasty generalizations are wont to be made in such matters. Of other classes a very large number would be scandalized no doubt also.

$$
\begin{aligned}
& \text { Believe me, } \\
& \text { Yours very faithfully, } \\
& \text { E. CANTUAR. }
\end{aligned}
$$

"The Penny Post is one of the ordinances of man that we have to submit to for the Lord's sake," Archbishop Benson is reported to have said at another time.

If $\mathrm{H} . \mathrm{H}$. was free for many years from the anxiety of fighting elections, he certainly did his part nobly 
in opening bazaars, laying foundation-stones, attending flower-shows, and all the multitudinous duties that fall to the lot of a Member. His love for the old city was reciprocated in many loyal hearts. He had friends in every walk of life, and many were the people who could speak of kindnesses shown them during the twenty-six years in which he was their representative.

$\mathrm{H}$. H. was never too busy to answer their letters in person, to secure an opening for some son or daughter; to assist the emigration of a family; or do the thousand and one little acts of kindness that do so much to ease the burden of life. His cheery presence and hearty greeting were known and loved throughout the city.

Among the pleasantest of $\mathrm{H}$. H.'s associations with Kent must be recorded his Presidency of the Men of Kent and Kentish Men. The Association was formed in I898, with Lord Harris as first President, and on his resignation in 1904 he was succeeded by $\mathrm{H}$. H. Never had a President a more loyal body of supporters, and during his years of office the membership grew from hundreds to as many thousands. Branches were formed in all parts of the Empire, forming yet another link between the old country and her dependencies.

When the battle cruiser H.M.S. "Kent" was commissioned, the Men of Kent and Kentish Men signalized their interest by presenting a magnificent shield to the ship. In response to an appeal from Captain D. A. Gamble, the Maids of Kent embroidered a silken ensign. "They may depend upon us," said Captain Gamble, "to keep it flying and never haul it down in dishonour." Words literally fulfilled when, on December 8th, I9I4, Captain J. D. Allen, flying the 
ensign, went into action, chased, engaged, and, single-handed, sank the German cruiser "Nürnberg" The ensign, which flew all the time, was torn to ribbons.

The complimentary dinner given by the Association to the Kent Eleven in Igo6 was a very brilliant function. H. H., apologizing for the unavoidable absence of the Right Honourable Alfred Lyttelton, "who was trying to bowl out or stump out or catch. out our present Government," read the following letter :

\section{My deAR Henniker Heaton,}

I am extremely sorry to say that in the existing state of things I cannot leave the House for the banquet to which you were so good as to invite me. Will you express my deep regret at my inability to attend. I can assure you that no one viewed the news of the Kent victory with more satisfaction than myself.

For that victory was achieved by the qualities which I think make cricket worth playing, dash, enterprise, adventure, as well as resolution and tenacity. Long may such qualities flourish in Kent and elsewhere.

Yours very truly,

A. Lyttelton.

An original gift was made to $H$. $H$. when the Society presented him with a large solid silver envelope, bearing the Canadian penny stamp.

On H. H.'s retirement from Parliament, the Men of Kent and Kentish Men gathered a brilliant company together to bid him farewell at a banquet at the Trocadero Restaurant.

The chair was taken by the High Commissioner for New Zealand, Sir William Hall-Jones ; and among those present were the High Commissioner for Australia, Sir George Reid; the High Commissioner for Canada, Lord Strathcona; the High Commissioner for South 
Africa, Mr John Burns; General Sir John French, Mr Marconi, Lord Blyth, Sir Edward Clarke, Sir John Cockburn, and the Postmaster-General, Mr Herbert Samuel.

Lord Strathcona in the course of his speech said that when he first went to Canada, seventy years before, letters from England to Canada cost from 4s. to 8s.

The Right Hon. Herbert Samuel, the PostmasterGeneral, in proposing the toast of "The British Empire and Imperial Communications," said that " that was an occasion of pleasure and of deep regret, since it signalized the retirement from active public life of their friend $\mathrm{Mr}$ Henniker Heaton. PostmastersGeneral came and went with sometimes bewildering rapidity, but they were accustomed to think that $\mathrm{Mr}$ Henniker Heaton went on for ever, and for his own part, he would believe Mr Heaton-whether in Parliament or out of it-had given up active work as a postal reformer when he saw it and not before. He thought he could claim that for the Postmaster-General of the day to attend a banquet at which $\mathrm{Mr}$ Henniker Heaton was the chief guest, showed something in the nature of a forgiving spirit. They all knew that his favoured form of sport was the baiting of PostmastersGeneral. His was the task of sticking the bandillero into the quivering shoulders of the infuriated animal. (Laughter.) $\mathrm{He}$ it was who waved in front of its eyes the red cloak of penny-a-word cablegrams, and, when the infuriated beast charged, with graceful and sylph-like agility, slipped over the barrier.

"It was a great public service which $\mathrm{Mr}$ Henniker Heaton had performed in continually keeping on the alert the individual, whoever he might be, who was at the head of the great Department of State over 
which he had the honour to preside. Mr Henniker Heaton had, however, rendered an even greater service in instilling into the public mind a divine discontent with things as they were, and ultimately his efforts had had some effect on the Treasury, a Second Chamber through which postal measures had to pass, a formidable and lethal Chamber.

"The whole of the country-irrespective of partywas grateful to $\mathrm{Mr}$ Henniker Heaton for the long life which he had devoted to the cause of postal reform."

Looking round the hall, $\mathrm{H}$. H. felt himself not at a public dinner but among trusted friends.

Each birthday, each postal victory, each hardfought election brought a message or cablegram from the Men of Kent and Kentish Men to their President. The names most closely associated with $\mathrm{H}$. $\mathrm{H}$. were H. J. Hearn, James Bills, G. B. Bayley, J. T. Hearn, A. O. Callard, R. Pilcher, Newton Jacks, T. S. Whittaker, W. H. Le May, E. Bennett, H. T. Wilkens, A. H. Shine, P. H. Holt, G. Clinch, R. Larking, E. M. Arnold, and Henry Thompson. 


\section{CHAPTER IV}

\section{AS A CHESS-PLAYER}

"Was it right, I say, and consistent with thy duties to sport away thy evenings amidst the vanities of Chess ?"

Letter from Cardinal Damianus to a Bishop, A.D: I06I.

HESS is the only game permitted in the House of Commons. Somewhere about I885 H. H. discovered a solitary and ancient chess board, in the smoking-room of the House, which tradition said had belonged to a former member for Deptford. H. H., who, like many others, found time hang heavy upon his hands, immediately seized upon the board and in a very short time a crowd of enthusiasts were gathered round.

The crush of spectators became so great that the players proposed to start a five shilling subscription, and a Chess Committee was formed. Among the earlier players were Sir Charles Russell, Lord Randolph Churchill, Parnell, Sir George Newnes, Charles Bradlaugh, and others.

Speaking many years later H.H. said :

" Lord Randolph Churchill was a very impatient player; he used to suffer so much in thinking out his moves. Bradlaugh was by far the most astute player, but Sir George Newnes, who was the greatest player in the House in those days, could beat him. Parnell was not a particularly strong player. $\mathrm{He}$ used to look on a good deal. But the man who would make the merriest comments, who would send ripples of laughter round the room, particularly when Parnell 
was playing, was the O'Gorman Mahon, the most notable character that ever figured in the House, and the last of the old Irish warriors and duellists."

For several years $\mathrm{H}$. $\mathrm{H}$. was chairman of the Chess Committee and he was the moving spirit in organizing matches.

The most interesting tournaments were those played in 1897 between the House of Commons and the United States Houses of Parliament at Washington.

The Speaker of the House of Commons wrote as follows :

Dear Mr Henniker Heaton,

Thanks for your note about the Chess-Match. I hope the best side will win, and I hope, too, that the best men will be found on this side of the Atlantic.

Believe me,

Yours truly,

$$
\text { W. C. Gully. }
$$

The match was played by cable, a telegraph line running into each House.

Sir Horace Plunkett, Mr Atherley Jones, Mr M'Kenna, Sir Charles Shaw, and Mr Parnell's brother were amongst those who played for the House of Commons. The late $\mathrm{Mr}$ Arthur Walter of the "Times" offered a magnificent trophy of Persian Chessmen, and paid the whole of the expenses.

The match was fiercely fought and ended in a draw : two and a half games to each side. At one time the defeat of America seemed imminent and the chairman of the American side cabled "We don't think this fair : we will play you poker."

Throughout the game there was a pleasant flow 
of intercourse. One of the English team was unavoidably detained, and a message was sent to his opponent asking for a few minutes' grace. "Why, certainly, don't hustle him," came back over the wires and raised a smile.

An inter-parliamentary match between England and Australia was arranged in IgII. The following letters are from the then First Lord of the Admiralty:

Dear Henniker Heaton,

I feel proud that you should have thought of me as a possible Captain for the British team in an inter-parliamentary chess match with Australia. I am sorry to say, however, that chess has been so far from my mind for the last six years, that I should be quite useless in the post. I have not played once myself since I have been in Office, and I know nothing of the players in the House of Commons. These are reasons, too strong to be overcome, against my accepting your very kind proposal.

Yours sincerely,

Reginald M'Kenna.

Dear Henniker Heaton,

You have always justly been considered the most persuasive of men, and your achievements in Post Office reforms are evidence of the truth of this opinion. In the present case, however, I feel strongly that your blandishments ought not to prevail and must not.

I am glad to be able to tell you that your son Arthur is being appointed First Lieutenant of the "Torch" on the Australian Station, an appointment which I understand to be acceptable both to him and to you.

Yours sincerely, Reginald M'Kenna. 
Mr Watson Rutherford, M.P., has very kindly sent the following reminiscence:

"In the course of the few years which followed my entering the House of Commons in January, I903, several matches were played against the joint teams of the Universities of Oxford and Cambridge, each of which was organized and largely carried out by $\mathrm{H}$. $\mathrm{H}$.

" He was passionately fond of the game, and though he did not attain first place amongst its skilled devotees he was remarkable for the rapidity of his games, and the amount of good humoured enjoyment which he was able to get out of them, whether he won or lost.

" $\mathrm{H}$. H. also was principally responsible for the arrangements made in connection with two or three annual tournaments amongst the members of the House of Commons itself, chiefly in connection with the challenge cup which was given by $\mathrm{Mr}$ Bonar Law, which cup afterwards was won by that gentleman himself, and subsequently presented by him as a sort of trophy between the Universities of Oxford and Cambridge and the House of Commons, and is at present held by the Universities in consequence of their having won the last match.

"Although $\mathrm{H}$. H. was not in the first rank of chess players from the point of view of chess skill, yet his presence and services were of the greatest possible utility to the chess players in the House in consequence of his being a universal friend and favourite. His high powers of organization and the amount of persuasiveness he brought to bear upon any project he had in hand were sufficient to carry it to a successful issue under almost all circumstances.

"Although the chess playing group in the House of Commons has suffered very severe diminution as regards both number and talent, as will readily be seen from the list of names above mentioned, I believe that on the whole the playing standard to-day is 
almost as high as ever it was, but we are sorely lacking in that very element of organization of which we were deprived when $\mathrm{H}$. H. quitted the House."

The rapidity of $\mathrm{H}$. H.'s game was a source of constant amusement, and the introduction of "Henniker Heaton Lightning-games" became popular.

The method was to move so rapidly as to prevent the players having time to think out problems. To add to the excitement the Division Bell often rang in the midst of a contest and the best of players became so utterly disorganized that the results were frequently mirth-provoking.

"It isn't chess at all-it's skittles," a disgusted victim once exclaimed, and the name found favour among its devotees.

Apart from chess in the House, H. H. was very keenly interested in the Imperial Chess Club which was started by Mrs Arthur Rawson. The first two Vice-Presidents were Lord Claud Hamilton and H. H., and the Club was opened by the latter in Igrr. As its name suggests, the Club provides a centre where visitors from oversea-dominions may meet in the friendly atmosphere of the great chess republic.

In going through $\mathrm{H}$. H.'s papers a surprising number of telegrams were found written in the vernacular. His election to Canterbury was hailed by his chessplaying friends in the House " Noble move."

When, in I908, H. H. started his crusade for pennya-word telegrams throughout the Empire Sir John Randles wrote :

My dear Henniker Heaton,

In chess an infinite number of moves and combinations are possible. The bold far-seeing player 
finds new combinations and is rewarded when he cries check followed by mate.

You have done much and played a great pawn game in development of the International penny post, when you fairly cried "Check." Bring out all your pieces, you will need them, and may you see the time when telegrams a penny a word the wide world over will enable you in more senses than one to cry "Mate." 


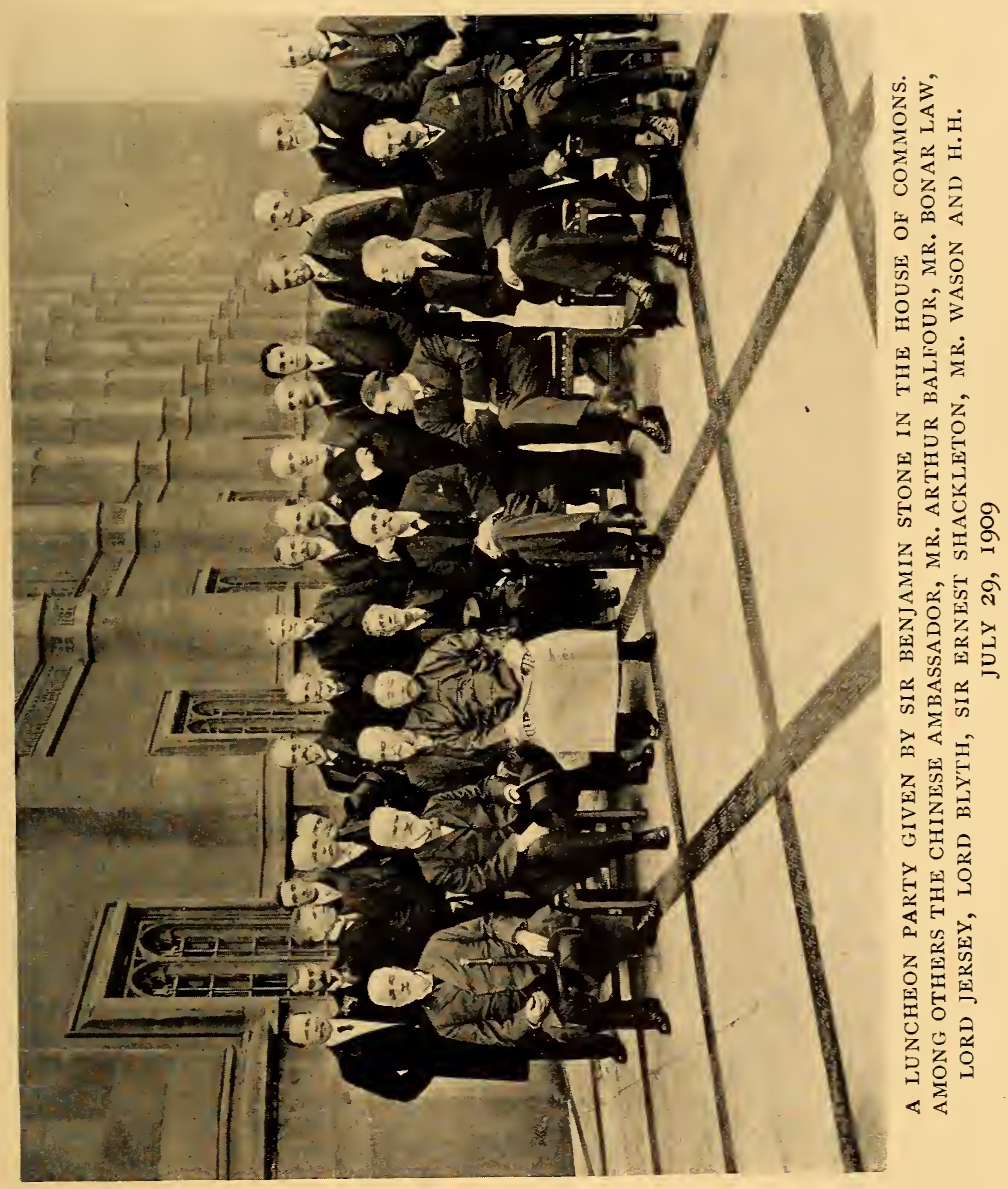





\section{CHAPTER V}

\section{AS A TRAVELLER}

\section{BY LAND}

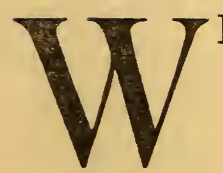

HEN the Duke of Wellington was asked his opinion of the English climate he is reported to have said: "For six months in the year the English climate is the best in the world, and for the other six I'm damned if I know a better."

This was a very favourite quotation of H. H.'s, and he could speak with some authority, having tried the climate of most countries in the world. Although he thought so highly of the health-giving properties of the English air, the fact remains that he never willingly spent a winter in England if he could possibly be anywhere else. His friends accused him of "Spending his week-ends in Japan "- a not unfair comment on his meteor-like journeys across the world.

H. H. and Lady Heaton, who shared a devoted love of the sea, spent a good deal of time on the Sussex coast. The gorse country round Bexhill and the picturesque old Sussex villages added greatly to the affection they had for the neighbourhood. The crystal-clear air and the invigorating breezes would send $\mathrm{H}$. H. back to work with renewed life.

Rest, as other people understand the word, was unknown to him. The only relaxation he found was in travelling about at full speed, meeting fresh people 
and seeing fresh countries. London was of course his head-quarters, and he had towards London very much the same feeling as Dr Johnson: "The happiness of London is not to be conceived but by those who have been in it. London is nothing to some people, but to a man whose pleasure is intellectual London is the place."

H. H. also shared Dr Johnson's antipathy to Scotland. This was perhaps the more extraordinary, in that it was the only country in the world that anyone ever heard him mention without some warm words of appreciation. His prejudice was founded on his one and only visit to Scotland. $\mathrm{He}$ arrived at Edinburgh early one Sunday morning to find the rain descending in torrents and a hurricane blowing. There were no cabs at the station and there appeared to be no means of reaching his hotel. The only other passenger was Lord Aberdeen, and together they waited for some chance conveyance. At length, a rattle of wheels was heard and a milk-cart came into sight. The obliging milkman allowed them to stand up in his cart, and drove them off in triumph along Princes Street! It was in vain that the younger members of H. H.'s family lauded the glories of the Highlands : to him Scotland always remained a rain-sodden morass where the inhabitants invariably drove about in milk-carts.

Ireland, on the other hand, was the country of his heart. Irish songs, Irish poetry, soft Irish voices, all made an irresistible appeal to him. For many years he and Lady Heaton spent every Whitsuntide in Ireland, and counted it among their happiest memories. There was something akin to his own nature in the spontaneous warmth he met on all 
sides, and the friendly welcome that falls so easily from Irish lips.

One " foine saft marning" in Kerry he and Lady Henniker Heaton went to look over a church, and, as they passed through the gate, a low voice was heard ejaculating in tones of deep piety: "Hivin be proised, all the foine gintilmin and the illigint ladies are not dead yit." It long remained a point of dispute as to which of them gave the old man half a crown, but they both agreed that such speeches do much to sweeten life in this unappreciative world.

Every August for over twenty years H. H. made a pilgrimage to Carlsbad. $\mathrm{He}$ attributed his extraordinary good health to the three weeks he spent there every year, drinking the waters and taking the cure.

In December, I88I, H. H. and Lady Heaton were present at a Canonization at Rome, which he describes in a letter to a friend:

"The ceremony of Canonization was fixed for eight a.m., but we were advised to be at the Vatican not later than half-past seven o'clock. It was hardly light at six o'clock when we breakfasted in our rooms, and by seven o'clock carriages commenced to roll into the courtyard of the Hôtel de Rome.

"Punctually at half-past seven we arrived at the Bronze Gate of the Scala Regia, or Royal Staircase of the Vatican, and were confronted by an array of Swiss Guards. These soldiers are specially attached to the Pope. Their picturesque costumes were designed by Michael Angelo. Their duties are to guard the Vatican, and on this special morning they were told off to see that no person entered the precincts but such as held personal orders of admission to witness the great ceremony of Canonization. 
"Shortly after we had taken our places, the Ambassadors from France, Austria, Belgium, Russia, Holland, Bavaria, Spain, and other countries, filed in, and entered the Tribuna. They looked very striking and attractive in their court dresses, their breasts being covered with decorations of various orders. The Ambassadors' wives, wearing veils and sparkling with jewels, accompanied their lords. German, Austrian, Spanish, and other nobles were ushered in by some high dignitaries connected with the Vatican. Just before ten o'clock, two officers of the Noble Guard took their places to the right and left of the papal throne. The Noble Guard, I should have stated, consisted of the noble or royal families of Rome who still remain loyal to the Pope.

"At half-past ten o'clock the Swiss, the Palatine, and Noble Guards, to the number of two hundred and fifty, filed in and made a passage up the centre aisle, and presented arms to their commanding officer. Then the magnificent choir of St Peter's struck up an anthem of welcome. The silver trumpets sounded for the first time in fourteen years, and a long line of Cardinals, Archbishops, and Bishops, fully mitred, entered the Hall of Canonization. The grandest looking of these Cardinals was an Englishman, Cardinal Howard. Each dignitary was attended by a chaplain. Among the Bishops were several Chinamen, Greeks, Armenians (which surprised $\mathrm{me}$ ), and Indians, in addition to German, French, English, Spanish, and Irish prelates.

"After the long line of dignitaries, to the number of two hundred and fifty, had marched in, a murmur arose, and then, amidst breathless silence, his Holiness Pope Leo XIII., entered. A signal was given, and every soldier fell on his knees and presented arms. All eyes were strained to catch sight of the great ruler of men's minds, whose sway over the spiritual welfare of two hundred millions of human beings excites the 
wonder of England. Borne aloft on a Chair of State, on the shoulders of eight men, his Holiness entered, waving his wan thin hand, bestowing his blessing on the right and on the left to the kneeling multitude. He wore his tiara, or triple crown. Having arrived at the pontifical altar, the chair was lowered, the Pope was conducted to his throne, and the ceremonies commenced. Thirty-two princes of the Church, or Cardinals, first approached, knelt before the throne, and kissed the Pope's ring of office. Fifty Archbishops then approached and kissed the Pope's knee, and two hundred Bishops followed in quick succession, knelt and kissed the Pope's right toe, in token of their fidelity and obedience to the successor of Peter.

"The ceremony of Canonization then commenced. The tiara was removed, and his Holiness knelt before the altar and prayed. Then followed the formal demand for the Canonization of Joannes Baptista Rossi, Canon of St Mary in Cosmedin, who was born in Liguria in 1698 ; Laurentius di Brindisi, a Capuchin, who was born in I559; Joseph Labre, a mendicant, who was born in I748, at Amettes in France; and Clara de Montefalco, an Augustine nun, who was born in I268. The decree was read, and, after the third demand, the Pope celebrated High Mass, and was served or waited upon by some Roman nobles and Cardinals. After Mass, or before its completion, the oblations were presented to the Pope. About fifty or sixty Bishops, Priests, and Franciscan brothers approached the throne, and presented Leo with gilded bread on plates of silver, wine and water in gold and silver barrels, and a number of cages containing live doves, pigeons, and smaller birds. Then the Cardinal Procurator offered to his Holiness a document in a purse of white silk embroidered in gold, and it was ordered that the news of the Canonization be sent abroad, and be proclaimed in all parts of the earth.

"It was three o'clock before the ceremonies and 
grand music had concluded, and the sediari and porta flambelli re-entered-eight of the former to carry the chair, and the two latter one on each side of the chair -bearing enormous fans to keep his Holiness fanned, and supplied with cool, fresh air. To the strains of solemn yet joyful music the Pope and Bishops passed out again in procession, and the Canonization was completed."

It was with special appreciation, more than twenty years later, that $H$. $H$. read the "In Memoriam" lines to Pope Leo XIII. in "Punch" by Sir Owen Seaman:

"The long day closes and the strife is dumb, Thither he goes where temporal loss is gain, Where he that asks to enter must become A little child again.

And since in perfect humbleness of heart He sought his churches' honour, not his own, All creeds are one to share the mourners' part

Beside the empty throne."

Travelling on the Continent with $\mathrm{H}$. H. gave, perhaps, the best illustration of his monumental energy. Station-masters and porters knew his familiar figure rushing down the platform with arms burdened with every conceivable newspaper and magazine, which he read at lightning speed. At each stopping place he jumped out to buy a fresh armful of papers, until by the end of the journey the carriage was nearly snowed under. He invariably met some of his numerous old friends or parliamentary colleagues on the train, and would spend hours playing bridge or exchanging reminiscences.

He would then open a bulging despatch bag containing postal blue books and correspondence, and 


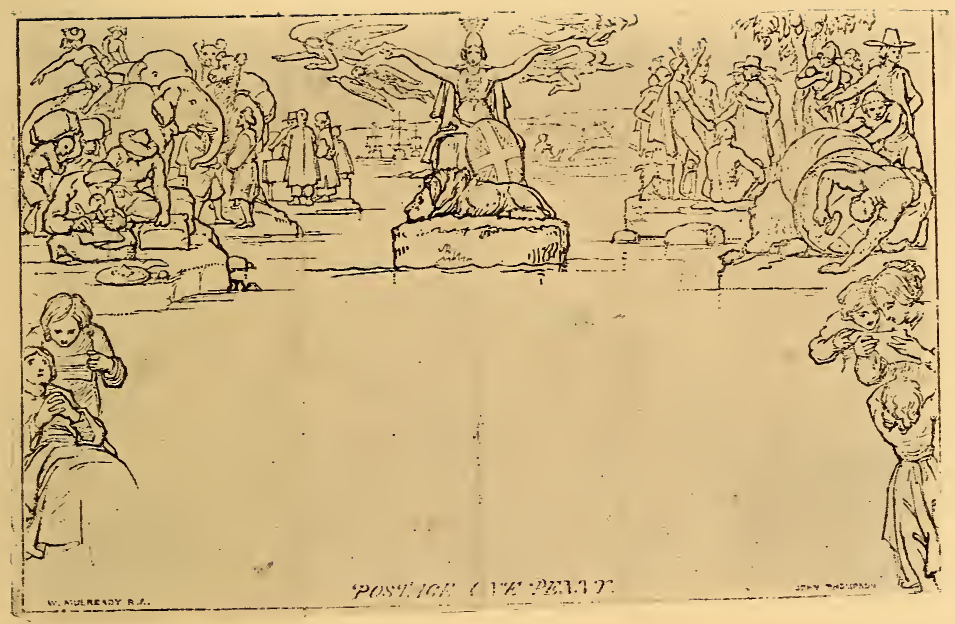

THE MULREADY ENVELOPE

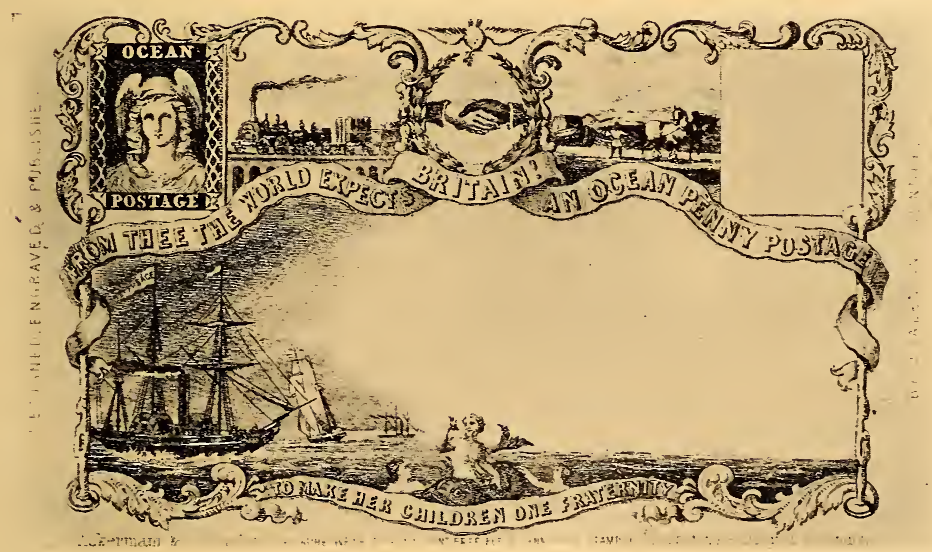

ENVELOPE ISSUED BY ELIHU BURRITT, ADVOCATING OCEAN PENNY POSTAGE 

would set to work upon them for a couple of hours, oblivious of all surroundings. In this fashion the journey would be accomplished, and he would reach his destination perfectly fresh and anxious to join in any festivity that was taking place. It is entirely characteristic of him that on one occasion, when he and his daughter reached Cologne at two in the morning after a sixteen hours' journey, he should propose showing her over the Cathedral then and there.

The opening of the year usually found him on the Riviera with his family. At one time they made their head-quarters at Monte Carlo, but latterly they preferred wintering at the beautiful Winter Palace at Cimiez. "If it were not for the Rooms, Monte Carlo would be the health resort of Europe," was the opinion of Sir William Jenner, and it has certainly a far milder climate than the rest of the French Riviera. It was when he was staying in the Principality that $\mathrm{H}$. $\mathrm{H}$. received a letter from his agent at Canterbury earnestly entreating him on no account to date his election address from Monte Carlo!

H. H. was never a great gambler, but he thoroughly enjoyed an hour or two in the Rooms. He used no elaborate system, but staked on Zero every time, besides playing on various combinations of the number 9. Nine he always considered his lucky number. It became an accepted thing in his family that on arrival at any strange hotel he should be given Room 9 or 99 , or any sleeping berth on board ship would almost invariably be either of those numbers.

The Rules and Regulations governing the Casino are very strictly enforced, and $H$. $H$. could remember seeing Lord Randolph Churchill turned away because he was wearing brown boots, while another Chancellor 
of the Exchequer-Mr Lloyd-George-met the same fate because he wore a Norfolk coat. The latter case was particularly annoying as the rest of the party, who had also been golfing, were allowed in the Rooms on the strength of their being clad in plain country clothes-a fine distinction that evidently appealed to the door-keeper.

Most Monte Carlo stories are too well known to be worth repeating, but $\mathrm{H}$. $\mathrm{H}$. was particularly fond of the oft-told tale of the man who rose from the tables muttering "Ruined! Ruined!" as he staggered out of the room. A minute later a shot was fired in the garden, and the officials, rushing out, found the man lying in the middle of the path with a smoking revolver in his hand. In accordance with custom the officials stuffed his pockets with bank notes ere they went to get assistance.

The moment they were out of sight the "corpse" rose to his feet, and re-entered the Casino. The indignation of the officials can be imagined when after a hue and cry they finally discovered him playing a winning game of rouge et noir with their money, secure in the knowledge that they dared not arrest him.

On the brow of the hill just opposite the Casino stands the little English Church. On one occasion as the first morning hymn-No. 4-was given out, one of the congregation rose and left the building. $\mathrm{He}$ hurried to the casino to put a sovereign on 4 en plein. It turned up three times running. The lucky winner could not keep such a piece of good fortune to himself, with the result that on the following Sunday the church was packed to the brim. As the first hymn was given out there was a perfect stampede for the door, as the gamblers young and old rushed to the 
Casino. Needless to say the number did not turn up ; but that is the reason why the authorities have found it advisable to discontinue the use of all hymns numbered lower than 37 .

The visits to the Riviera were rendered doubly enjoyable by the presence of Sir Charles Gavan Duffy and his charming gifted daughters, who lived at Nice, and entertained every one of distinction and brilliance. Sir Charles lived to the great age of 84 , and was never tired of talking of his early days when he was the leader of the Young Ireland movement. His conversational opening, "When I was in prison," was a little startling to anyone unacquainted with his romantic history.

At Nice one morning when $\mathrm{H}$. $\mathrm{H}$. was having $d e-$ jeuner with him, Sir Charles called over a waiter to tell him that he wanted the claret bottle to be corked.

"Garçon"- -he began, but forgot the French word"Garçon, voulez-vous-voulez-vous-bouchoir bouchon -boucher" - all the time waving the claret on high"what the devil's the word?"

"Shure and is it corrk yer honour was afther wantin'?" said a mellifluous voice in the purest Tipperary, and the "garçon" was joyfully hailed as a compatriot by Sir Charles.

Sir Charles was constantly receiving letters from England insufficiently stamped, which necessitated his paying the extra postage. After a time he became so incensed that he declared he would no longer accept such letters. Soon after this a letter arrived addressed in H. H.'s flowing hand and bearing a penny stamp. This was altogether too much for Sir Charles-who quite reasonably thought that $\mathrm{H}$. $\mathrm{H}$. of all people might be expected to know better-and he positively declined to take the letter in. One of his daughters, 
feeling this was rather hard treatment of an old friend, ran after the postman and paid the fine herself. When the letter was opened it was found to contain a cheque for fIoo. $H$. $H$. had made arrangements for the publication of Sir Charles's "Life of Carlyle," and this was the first cheque from the publishers.

This little episode when repeated to $\mathrm{H}$. $\mathrm{H}$. confirmed him more fully than ever in his opinion that the English post office is grossly unfair in fining the innocent recipient double postage. Sir Charles under the more generous French system was, after all, only asked to pay the exact amount due.

A letter from Sir Charles, at Nice, to H. H., at Cannes :

My DEAR HEATON, or Pau.

You are demented to think of going to Rome

You left London to avoid the cold, and there is cold everywhere in Europe except where you are. Sit still and enjoy the sunshine, and you may turn your leisure to good purpose by planning the business of next session as far as you are concerned. If the Government include Penny Postage in their programme it will be a great triumph for you.

I answered your last letter to London, but I will answer you again if you come over to lunch some day, say Wednesday, or any other day that suits you better, if you send me a telegram the night before.

If it be reasonably probable that Penny Postage is coming on, you ought to prepare a short modest, practical speech, on that success, and an alternative one to be ready in case the Government do nothing. Here is work for a fortnight better than scampering over Europe. When I see you I will suggest something still more necessary to be done in your brief holiday.

Always yours,

C. Gavan Duffy. 
Sir Charles also wrote the following from Nice to H. H., in London :

\section{My DEAR HEATON,}

If Stead puts his ghost into "The Review of Reviews," his readers who endured with difficulty General Booth, and Mrs Besant, and all his other mad protégés, will certainly abandon him. The ghost is a ghost from Scotland Yard. In exchange for the Stead romance, I send you the last good mot here fit to tickle the midriff of the Carlton Club. One of the Members for this district, the late treasurer R., who had to resign in connection with the Panama business, admitted that he had got the money charged upon him, but declared that instead of applying it to his own use he had given it to the Secret Service fund! (Fonds secrets). The client of a lawyer was since detected in helping himself from the money on a bronze plate where the lawyer deposited his fees. "Que voulez-vous faire de cet argent-là ?" demanded the angry notary. "Mais, monsieur, l'envoyer au fonds secrets."

I hope you are coming out, it would be a wise disposal of the three weeks which remain. If so pray send me Parkes, and I will have it read and ready to return when you are going back to London.

If you desire it, or think any good end would be promoted, I shall be happy to see Mr W., but in truth I have no longer any desire to make new acquaintances. That is a pleasure for men in the vigour of life. Send him, however.

I take the "Times" during the sitting of Parliament, and shall see Gladstone's speech twenty-four hours after it is delivered. $\mathrm{He}$ has a frightfully difficult position with Labouchère and Company preparing pitfalls. The crux appears to be the retention of the Irish members at Westminster. For my part I am quite content they should be excluded from the British 
Parliament, if it be distinctly understood that a Parliament where we are not represented is not entitled to impose taxes on us. We would be in the same position as the Colonies and entitled to the same treatment.

Very faithfully yours,

C. Gavan Duffy.

It was always with regret that $\mathrm{H}$. $\mathrm{H}$. turned his back on the Riviera, where he so greatly enjoyed the blue skies and warm sunshine.

H. H. never travelled about without a mass of correspondence and other papers which, owing to his rooted objection to destroying even an envelope or old invitation card, would soon assume enormous proportions. It was his practice to leave these papers unpacked to the last, so that they might be read and studied up to the moment of departure. With the $\mathrm{cab}$ at the door they would be thrust into two bursting dispatch-cases, and porters would struggle to close a gaping tin deed-box. Even then $\mathrm{H}$. $\mathrm{H}$. never felt happy while they were out of his sight, and a stranger might have imagined that the boxes contained priceless jewels in place of postal guides and Blue books.

One particularly cold January, H. H. and his family returned from Cimiez to Canterbury for the election. It was a bitter night when they reached the hotel, and the rooms seemed very inadequately heated. The manager moved them into another part of the house, where they were agreeably surprised to find the sitting-room most beautifully warm and cosy. As the evening wore on the room grew hotter and hotter, and the hotter it became the more H. H. congratulated himself on securing immunity from the icy blasts outside. 
The reason of the unexpeected warmth was made apparent early the next morning, when $\mathrm{H}$. H., whose room adjoined the sitting-room, awoke to find himself half-choked with smoke. The sitting-room, which had been smouldering the whole day before, had now burst into flames. He tried to rush into the room to secure his papers, but was held back by the firemen who had arrived on the scene. $H$. $H$. offered a sovereign to anyone who would rescue his boxes, and one of the firemen dived into the smoke and reappeared with the precious dispatch cases and tin box unharmed. Family tradition says that $H$. H. drew a deep breath of relief and then suddenly exclaimed, " Good heavens! where are my children?"

But as everybody knows family traditions arewell, family traditions. 


\section{CHAPTER VI}

\section{AS A TRAVELLER}

\section{By WATER}

T $T$ was the opinion of $H$. $H$. that every Member of Parliament should be sent on a voyage round the world before being permitted to take his 1 seat at Westminster, which is after all only a paraphrase of Kipling's :

\section{"What do they know of England Who only England know ?"}

Such an accusation could not be brought against H. H., who visited almost every corner of the Empire at one time or another. Age could not alter nor custom stale his insatiable delight in sea-voyaging. The moment he got on board he felt ten years slip from him, and not the youngest traveller on his first voyage could enter more enthusiastically into boardship life.

It was a great pleasure to $\mathrm{H}$. $\mathrm{H}$. if he could find a good chess-player amongst his fellow-passengers, and many travellers will remember the groups that used to gather round the chess-board when he was playing. The hottest day in the Red Sea would find him engaged in a fierce contest with another ardent soul, upheld possibly by the thought of the long iced lemon squash which was always the stake for which he played in the tropics.

Although he must have made the voyage to 
Fair speed the Ship whose signal is unfurled CAn OCEAN PENNY POSTACE for che worlde. Loudoin, June. $89 \cdot 1853$ Mes Eclitor

Gore ruvedel confer a favous and parmate the suobrement for Gecon Recry Posloge by misesting the anclosed prosaysaphs

Grans bruly Guther, Sansite

(Orginal in the fossession of Aiexander Gilchrist, J.P.) 

Australia at least thirty times, his interest in the various stopping places remained as fresh as ever. He could never understand the attitude of the blasé traveller who refuses to be awakened at dawn to see Mount Etna smouldering, or to watch the passage through the Straits of Messina. That anyone should choose an unbroken night's slumber in preference to seeing or doing anything even mildly interesting was to $\mathrm{H}$. H. utterly incomprehensible.

Throughout his busy life he had the enviable faculty of dropping asleep at any time, anywhere, and after five minutes' light slumber waking up refreshed and invigorated. It was only after his serious illness in IgII that he learnt the misery of sleepless unending nights, and the slow coming of the longed-for morning. In speaking of insomnia one day at luncheon, at the Bath Club, Sir Josiah Symon, the Chief Justice of South Australia, quoted A. L. Storrie's verses:

"Measure me out from the fathomless tun, That somewhere or other you keep In your vasty cellars, $\mathrm{O}$ wealthy one, Twenty gallons of sleep.

Twenty gallons of balmy sleep, Dreamless and deep and mild, Of the excellent brand you used to keep When I was a little child.

Measure me out, O merchant mine, Twenty gallons of sleep."

$H$. H. repeated the last line, and those who were fond of him were struck with the sadness in his voice.

In his early days of travel $\mathrm{H}$. $\mathrm{H}$. had many exciting adventures, including three days in a cyclone 
and a collision. An account of the collision was found in an old diary :

"The P. \& O. Steamship 'Peshawur' (Captain E. J. Baker) left Gravesend on September I4th, I882, bound for Australia, having on board gI first-class passengers and 56 second-class, beside a heavy mail from England.

"She left Colombo on the evening of Saturday, October I4th. All went well until the following day, Sunday, October I5th. In the evening the majority of the first-class passengers were on the quarter-deck attending divine service. The evening was beautifully fine and clear. The service concluded at nine o'clock and the people were going to saunter about, when a large ship was noticed on the starboard bow with all sails set.

"The officer on watch, Mr Buchanan, alleges that when first seen the ship had no lights visible. Two minutes afterwards a red light was suddenly shown. This light was also seen by a large number of passengers from three to six minutes before the collision. One of the first to see it was Captain Baker, who had been attending prayers on the quarter-deck. He immediately rushed on to the bridge and, seeing the danger of his steamer continuing her course, he gave orders to stop the engines and a second order to go full speed astern in order to permit the sailing ship to pass-the rule being that a steamship should keep out of the way of a sailing ship

"Unfortunately at this moment, the master or captain of the ship also changed her course in place of following the strict regulations to keep on her way or port - the wind being on her port quarter. She luffed right up, starboarding her helm, and dashed into us.

"My cabin was on the port side near the engines and I was lying down reading. I had just looked at my watch and found it was nine o'clock, and I 
heard the bell ring to stop her. A minute afterwards I heard the bell ring for full speed astern, but at first thought it was merely stopping because the bearings were heated, which is often the case. However, to satisfy myself I leisurely got up and walking out found the purser and a passenger quietly smoking their pipes, and I concluded that all was right.

" However, I walked over to the foot of the stairs on the starboard side leading to the hurricane deck when like an avalanche there tumbled down the stairs from the quarter-deck about twenty passengers and stewards. I was knocked down and ' a ship on top of us' was shouted out. I rose and with a number of others made along the starboard side of the aft of the quarter-deck. Again I was knocked down, and on looking up I saw a horrible black mass above my head. I rose again and scrambled out of the way. The confusion and consternation about me were awful for a few minutes, and when the horrible unusually large red light drifted away there was some relief. All men, women, and children, to the number of I50, crowded to the after part of the deck and we expected our vessel to go down. My wife called for her little children, and you may imagine my horror when I pictured their being crushed to death, as I knew they were in bed apparently about the spot where the ship ran into us. I tried to descend the companion ladder into the saloon and found the refreshment bar shattered and a gaping hole in the side of the ship. The iceman, a native, was lying with an immense block of iron on his leg. On entering the saloon I found our nurse with the youngest baby in her arms all safe, and in the cabin I found our three little boys, Jack, Reggie, and Bertie, sound asleep, not even awakened by the awful crash a little above them. It was a great relief to hurry back on deck and tell my little wife that our children were safe.

"Passengers hurriedly compared notes and many 
were the miraculous escapes recorded. Where ladies were sitting a few minutes before there was nothing but wreckage. An immense quantity of stones, bricks, and mortar were strewn about-this being the cement from the bows of the other ship.

"The damage done to the 'Peshawur' where she struck near our centre consisted in cutting through our waterways, splitting and twisting up the iron plating below the main deck and knocking a hole through the side four feet above the water.

"The vessel in freeing herself carried away the bulwarks for twenty-five feet, carried away our gangway ladder, two large boats, that is, the life boat and the cutter, also smashing the standard compass bridge, the door of the captain's cabin, and breaking one of the booms.

"Our first duty was to find out if our steamer was sinking as we expected, but in a few minutes it was reported that we were making no water, and in fact that we were safe.

"The machinery gave a few revolutions, which further convinced us that all was well.

"Our next anxiety was for the other ship. On looking round we saw she had not sunk, for she was showing blue lights. Captain Baker gave orders to steam back close to the ship, and he sent a boat in charge of the second officer to ascertain the extent of her injuries and inquire if she wanted any assistance.

"The delay was somewhat painful, because the boat took a considerable time in returning in consequence of our ship having to steam some distance off to avoid a second collision.

"At last the boat drew alongside and the quartermaster shouted to the captain: "Glenroy," sir, bound from Mauritius to Madras and Calcutta, four hundred coolies on board and choleva broken out.'

"The second officer said that the captain of the 'Glenroy' (tonnage II39) reported the bow of his 
ship was completely knocked away, his fore compartment full of water, foremast badly sprung, and the ship making water through her foremast water tight bulkhead. She was an old iron ship of 25 years' standing. The captain's request that the 'Peshawur' would stand by him all night was of course complied with.

"When day dawned the full extent of the havoc was visible. We spent many hours endeavouring to make fast to the 'Glenroy' in order to tow her into port.

"Only five knots an hour was the speed allowed, because the other ship was making water very fast, although all hands were at work on the pumps.

" On Thursday morning at eight o'clock we arrived off Galle, where we signalled and obtained a pilot boat who took off our telegrams, and in the afternoon we arrived safely at Colombo without the loss of a single life."

The end of the story is worth recording. At the subsequent Inquiry it was proved there was no one on watch on board the "Glenroy" at the time of the collision; the captain and the first and second mates were playing cards. Before coming into court they had evidently agreed on all telling the same story, and, when each in turn was asked at what hour the accident happened, one after the other they replied: "Oh, half-past eight, or a quarter to nine or thereabouts; Oh, half-past eight, or a quarter to nine or thereabouts. Oh, half-past eight, or a quarter to nine or thereabouts." The unanimity of this simple utterance at once threw suspicion on their bona fides and ultimately led to their undoing. Truly was it written, the way of transgressors is hard.

In I875, the civilized world was shocked to hear 
of the murder of $\mathrm{Mr}$ James Woodford Birch, the British Resident of Perak. A full account of the assassination is given in Sir Frank Swettenham's book "Malay Sketches." The Sultan Abdullah and others were banished as accomplices, while the three chiefs who actually planned the murder were sentenced to death.

$\mathrm{H}$. H. was firmly convinced of the innocence of the Sultan Abdullah, and interested himself greatly in trying to secure his pardon, and partly as a result of his representations Abdulla's term of banishment in the Seychelles was considerably reduced; but as Mahé, the capital of the Seychelles, is locally supposed to be the original Garden of Eden, Adam and Eve would have considered this a strange form of punishment.

The ex-Sultan wrote the following letters to H. H. :

DEAR SIR,

$$
\begin{gathered}
\text { Port Victoria, Seychelles, } \\
\text { April I6th, I89x. }
\end{gathered}
$$

It is my melancholy duty to have to announce you the lamented death of my wife which took place on Easter day at 8 a.m. ; she leaves behind her several children to bewail her loss. This is to me all additional sorrow. Before this sad event I have been deploring my situation as an exiled man; now I have to deplore the loss of my wife. I think it is the will of the Almighty, and I therefore resign myself to Him, bearing in mind the Latin maxim " Per ardua libertas."

With my kindest regards,

Faithfully yours,

Sultan Abdullah, ex-Sultan of Perak. 


\section{SINGAPORE, \\ Ist May, I902.}

Dear Mr Henniker Heaton,

I have the pleasure to present and introduce to you my son, Rapas Chulan, the bearer of this letter, who accompanies Sultan Idris of Perak on the invitation of His Majesty's Government, to witness the Coronation.

I take this opportunity to again convey to you my heartfelt thanks for the kind assistance you have rendered to me in having worked for my release from the Seychelles. This is a debt of gratitude which it would be impossible for me to pay.

I am sorry to tax your kindness. I still solicit further help from you during this "Year of grace," the year of the Coronation of the King. I would even feel grateful if you would take this opportunity to approach His Majesty's Government and use your powerful influence and those of your friends to intercede for my freedom.

I have been in exile for 24 years. Whether I merit such treatment or not Heaven knows. I now seek for freedom and desire to return to my country, not to reside there entirely, but to be at liberty to go in and out as any free man.

Trusting you and your family are in good health, and with kind regards to all.

Believe me,

Yours very sincerely, ABDULlah, ex-Sultan of Perak.

On the various occasions when $\mathrm{H}$. $\mathrm{H}$. visited the Seychelles he always had interesting conversations with the deposed Sultan. One year Abdullah presented him with a wonderful collection of walking-sticks made of carved ivory and cinnamon wood. For 
some years $\mathrm{H}$. $\mathrm{H}$. had a rather unique collection of walking-sticks of strange shapes and designs, which were always kept in a dark corner in the hall of his Eaton Square residence together with the ordinary umbrellas and sticks. This not infrequently led to unforeseen results. One Sunday morning during the season a very dandified young man, who was stopping in the house, borrowed a stick and had walked halfway up the Square before he realized that he was carrying part of the jaw-bone of a shark. He went back to change it for an inoffensive-looking stick with a brown knob. It was only when he reached Church Parade that he discovered the inoffensive brown knob to be the head of Disraeli, while the rest of the stick represented a full length cartoon of the statesman. It was a wonderful piece of carving - a presentation to H. H. from some admirer in Canterbury. After this $\mathrm{H} . \mathrm{H}$. gave instructions for his curio sticks to be kept apart, and when he no longer saw them he speedily lost interest in his collection.

In $\mathrm{I} 883 \mathrm{H}$. $\mathrm{H}$. visited Mauritius for the first time, and thereafter his associations with the island were of the happiest. A feeling of mutual sympathy and friendship existed until his death, and all things that affected the progress and prosperity of the Island were eagerly watched by him. Letters and weekly papers from Sir William Newton kept him informed of the general progress of the Colony, and were an additional link in the chain of pleasant memories.

Mauritian friends must forgive a twice-told tale for the sake of an old friendship. At philatelic gatherings, $H$. $H$. could never resist his best-loved story of the keen but impoverished stamp collector who advertised "Wanted-to meet a lady possessing a 
2d. blue Mauritius stamp with a view to matrimony."

It was in company with Sir John Pope Hennessy - that stormy petrel of the Crown Colonies-that H. H. first visited Mauritius.

Prior to Pope Hennessy's appointment to the Government of Mauritius, he had been offered and had accepted the Government of New South Wales; but the appointment had been met by so determined a protest on the part of the New South Wales Ministers that the Secretary of State had been compelled to inform him that "the appointment could not be proceeded with."

A new friendship with $H$. $H$. inspired Pope Hennessy with the hope that he had found in him a man of sufficient influence over the Press and public opinion in N.S.W. to convert Ministers from their determination not to accept him as Governor.

The following year-I884-H. H., on the invitation of Pope Hennessy, used his good offices with the Colonial Office, and his influence with the Press, in support of a scheme of constitutional reform for Mauritius to which the Home Government was opposed on general principles of policy.

The form of constitution proposed was first set up in New South Wales in the year. I842, and by an Imperial Act of 1850 was extended to all the Australian Colonies except Western Australia. It was a form of Government expressly designed to serve as a bridge over which the Colonies might pass to the full liberties of self-government.

The advocates of the system included two parties: those who desired to see it carried out to what they conceived to be the logical consequence of complete separation from Great Britain, and those who desired 
to see it carried out to what they conceived to be the logical consequence of a federated British Empire. Pope Hennessy was an adherent of the former party, $\mathrm{H}$. $\mathrm{H}$. of the latter.

When the unwilling consent of the Colonial Office had been given to the constitutional changes proposed by Hennessy, the Colony became divided between adherents of the two parties. Pope Hennessy himself, in social conversation on the subject of Home Rule for Ireland, made no disguise of his adhesion to the policy of Home Rule with a view to complete separation. In public his use of the formula "Mauritius for the Mauritians" could leave no doubt of the ultimate issue he desired.

The stormy years that ensued, the suspension and subsequent reinstatement of Pope Hennessy, on the petition of the majority of the colonists, followed by his final retirement a year later, gave $\mathrm{H}$. H. cause for grave anxiety. His personal friendship and admiration for the brilliant attainments of Pope Hennessy were not always in accord with his views upon the policy adopted by the latter. "You cannot know what it is to live and, if necessary, to die for Ireland," Pope Hennessy said not without emotion when Sir Charles Bruce, holding the Office of Colonial Secretary, tendered his resignation, feeling he could no longer with honour support the Governor.

In I895, Sir Charles Bruce was offered the appointment of Governor of Mauritius, and accepted it as the supreme vindication of his action. During his administration, and largely due to his initiative, the penny postage system was extended to Mauritius. The influence Sir Charles exerted in the cause of cheapening and extending post and cable communi- 
cation proved of the utmost value to $H$. $H$. in voicing the desires of our distant Colonies.

In I884, H. H. wrote to the Governor of Mauritius on the subject of a duplicate cable to Australia via the Cape. Sir James Anderson, Managing Director of the Eastern Telegraph Company, had declared that the weather was so bad between the Cape, Mauritius, and Australia that it must always be next to impossible to effect repairs. It was proved that the contention of the Telegraph Company was ill-founded, and the outcome of $\mathrm{H}$. H.'s letter was that the Council of Government voted a subsidy for a term of years and resolved that he should be asked to represent the Colony at an International Telegraph Conference which was to be held at Berlin in June, I886. The cable from Natal to Australia, touching at Mauritius, was completed fifteen years later.

H. H. greatly valued a beautiful old French cruetset which bore the following inscription :

«Presented to J. Henniker Heaton, M.P., From GRATEFUl MaUritian Friends."

The mustard-pot belonging to the set was stolen by a dishonest servant, and all efforts to trace it proved unavailing. After a lapse of twelve years H. H. received a letter from the manager of a foundry, saying that a cup bearing his name had been brought in with some other old silver to be melted down. H. H. at once bought it back and the complete set is now in the possession of his son, Herbert Henniker Heaton, Assistant-Colonial Secretary of Mauritius.

A vote of sympathy was extended by the Council of the Government of Mauritius when the news of the death of $\mathrm{H}$. H. reached the Colony. 
Dr Laurent in proposing the motion said: "The Colony has lost a friend of many years and the Mother Country a distinguished Citizen.'

This last act of sympathy on the part of Mauritius could not fail to touch deeply Lady Henniker Heaton, who knew how warmly he had loved his old friends in the beautiful Island.

In $1889 \mathrm{H}$. $\mathrm{H}$. paid a flying visit to India and China, but, unfortunately, his stay in both countries was too short to yield much in the way of reminiscences. A complimentary notice, referring to his postal campaign, written by a Babu appeared in one of the papers two years later :

"Penny postage all throughout this wide world, which all pretty well belong with Great Britain, and the sun hardly never set on it shall be one of the certain accomplishments before conclusion of nineteenth century. When this desirable desideratum have been secured for us, to whom shall we lift eyes in token of gratitude for service done? Grand Old Man? No. Lord Lansdowne? No. Lord Salisbury? No, certainly not. When that day shall be arrived, let us then sacrifice ourself on bended knee and give all devotion and reverence-richly deservedto the noble Marquis of Canterbury, who elevate himself after many years hard struggle with it, up from Australian merchant to dictate terms of penny postage to commercial Europe and the world. And get it too."

H. H. paid a second visit to China and Japan a few years later, and while in Pekin he had the pleasure of meeting Sir Robert Hart, the famous head of the Chinese customs. A warm friendship existed between Lady Hart and H. H.'s family, and it was with great 
pleasure he renewed acquaintance with Sir Robert on his return to England after an absence of thirty years. Soon after his arrival in London Sir Robert and Lady Hart came to a tea party on the Terrace. H. H. asked him what struck him as the greatest change in London since he had left, and he replied instantly, "The noise." Lady Hart related that driving down to the House their carriage had got into a block, and the policeman in charge of the traffic held out his hand in the usual way; quite unused to this procedure, Sir Robert in great excitement leant out of the carriage and shouted, "For God's sake, move, man ; you'll be killed."

In I89o, H. H. made his first voyage to America. It was then he began his life-long friendship with the great Postmaster-General of the United States, the Honourable John Wanamaker. It was a friendship that had its roots in a common love of humanity and an abiding conviction of the necessity of a closer union between the two great English speaking races. Mr Wanamaker's heroic labours in connection with Anglo-American penny postage, during the time of and after he left office, undoubtedly paved the way for the consummation of his cherished ideal. He was one of the pioneers of an Anglo-American entente cordiale; and when he visited London he was the first American ever elected a member of the Carlton Club.

During H. H.'s visit to America, he spent much of his time visiting the large towns and inspecting the workings of their postal system. At a certain town occurred one of those accidents which happen not only in the best regulated families but also in the best regulated post offices. 
The postmaster called on $\mathrm{H}$. $\mathrm{H}$. and offered to show him over the post office. In those days the employment of women as clerks was something of an innovation. The postmaster waxed eloquent on the subject of their superiority over men: they were more industrious and trustworthy, and as they neither drank nor gambled they had less temptation to dishonesty.

When $\mathrm{H} . \mathrm{H}$. and his conductor reached the post office, they were surprised to find no clerks behind the counter, while a long queue of customers were waiting with every visible sign of annoyance. The postmaster, followed by $\mathrm{H}$. H., pushed his way to the back office and opened the door.

His horrified ears were greeted with cries of, "Ladies to the centre. Gentlemen give the right hand. Set to partners."

The immaculate young women of the post office were having a dance!

The mortification of the poor postmaster knew no bounds. Such a thing had never happened before, and was never likely to happen again, he assured $\mathrm{H}$. $\mathrm{H}$., who, needless to say, was highly diverted.

The postmaster's cup of humiliation was, however, not yet full. He took H. H. to see a wonderful machine for " postmarking" stamps. Up till then all stamps were cancelled by hand, a lengthy process requiring the services of several clerks. By means of this new invention several hundred stamps were done a minute, with the consequent saving of labour and money. H. H. picked up a handful of letters and examined the postmark with some care.

"I see they are all stamped with yesterday's date," he said. 
It was only too true. The clerk in charge had forgotten to alter the date. Kindness suggests that a veil be dropped over the sufferings of the unfortunate postmaster, who sank into a fit of impenetrable gloom, from which H. H.'s sympathetic assurances that "these accidents will happen" could not suffice to arouse him.

It may here be mentioned that America was first in the field with a postmark that was clear and readable, with the date, hour, and place clearly printed. Under H. H.'s persistent efforts, the indecipherable smudge that obliterated the Royal features on our English stamps gave way to a fair imitation of the clean cancelling used in America.

In the winter of $1905-6, \mathrm{H}$. H. made one of his periodic visits to Australia. On this occasion he decided to make the return journey via Fiji and America, so that he might have the opportunity of seeing his son, Herbert, who was then in the Colonial Office in Fiji. The Governor at that date was Sir Everard im Thurn, who gave a most cordial welcome to $\mathrm{H}$. H., and began a friendship which was continued by an exchange of letters for some years. H. H. was astonished to find such signs of civilization in far-off Fiji. Shops with plate-glass windows and electric light all seemed very far removed from the cannibal island of popular imagination.

It was a great pleasure to $H$. $H$. to see his son after so many years, and to hear of his early experiences in the Colonial Office of Fiji. As a very junior cadet he was sent out to make a report of a neighbouring island. His youthful enthusiasm received a slight check when the report was returned from head-quarters with the gentle reproof scribbled across it, "You 
write as one having authority and not as the scribes."

H. H. was greatly entertained by his son's experiences as a magistrate, administering justice amongst these simple children of nature. On one occasion when he was on the bench a woman summoned a man for ill-treating her, and knocking her down. The man's defence was that she was his wife, and therefore he had every right to do as he pleased in his treatment of her. She stoutly denied being his wife, and maintained that they had been baptized together but not married. Judgment was given in the woman's favour, but, after the court closed, the magistrate, feeling a little uneasy about the affair, consulted the Bishop. From the Bishop he learnt that the couple had been neither married nor baptized but were vaccinated together!

H. H. and his son had a number of stories to tell each other, and at the end of two hours' conversation his son said :

"And now I must tell you we have had a cable from England announcing the Government's resignation, and I am afraid you will have a great rush to get home in time for the General Election."

" Impossible," cried H. H. " Before I left I had an assurance from Balfour that no election would take place for a long time. Why didn't you tell me the moment I landed ?"

"Because," replied the son of his father, "I have been away five years, and I wanted to hear all the home news, and I knew if I told you about the General Election I should never hear a word."

H. H. hurried across America in a fever of impatience. By the generous kindness of Sir Thomas 
Shaughnessy, the President of the C.P.R., special arrangements were made which enabled him to catch the ship to England with two hours to spare. $\mathrm{He}$ reached Canterbury just in time for the election and was returned by a majority of one thousand.

While in America, he heard that his name was included in the New Year's Honours as K.C.M.G., and he at once cabled home to decline the honour.

On his return, he found many letters of congratulation awaiting him; among them a line from the Commander-in-Chief in India-Kitchener of Khartoum :

My dear Henniker Heaton,

\section{Fort William,} Dec. 2I, '05.

I am very glad of this opportunity of congratulating you heartily on the K.C.M.G. you have so well deserved.

KITCHENER. ${ }^{1}$

In $1907 \mathrm{H}$. H. experienced his second earthquake, the first having occurred in the South of France in the late eighties, which was not attended by very serious results. In this year he sailed for Jamaica in the "Port Kingston," and enjoyed the pleasantest of outward bound voyages in congenial company.

His own account of the earthquake is given:

"We arrived on Friday, Irth January, at Kingston, the capital of Jamaica, and on the following morning we went by railway to Port Antonio, which is 49 miles from Kingston, where we were entertained at

${ }^{1}$ Some words, written by Lord Kitchener of $\mathrm{H}$. H. after his death, expressing his "friendship and sincere admiration of his services," are doubly prized as coming from the great soldier and statesman who at the moment of writing held in his hands the safety of England and the Empire. 
a banquet and ball. Port Antonio is one of the loveliest spots on earth, and the fine hotel is splendidly situated. It is almost an island, being surrounded on three sides with water, with a narrow neck of land connecting it with the mainland. We returned on Sunday morning. Our train stopped at several beautiful places along the seashore, and we arrived at Kingston about midday. In the afternoon we had tea at the residence of the Hon. Clarence Bourne, the Chief Secretary of the Colony, where we met Sir Alexander Swettenham, and other notabilities of the island, including Colonel Kitchener, brother of General Lord Kitchener. Our party were lodged at the Constant Spring Hotel, and on Monday morning we went into the city to attend the Agricultural Conference, where the wealthy representatives of the whole of the West Indies were assembled to consider methods for the development of the cotton, sugar, rubber, and other industries. Admirable speeches were made by the Governor, Sir J. A. Swettenham, the Archbishop of the West Indies, and other leading men.

"I was invited by the Governor to lunch with him at the Jamaica Club with several others, including Sir James Fergusson, formerly our Postmaster-General, Sir Daniel Morris, the Hon. Clarence Bourne, and Mr Arnold Forster, M.P., late Secretary of State for War. We had a very interesting luncheon at the Club, which was a fine building, two storeys high, constructed of brick, and surrounded by a high brick wall. We rose from the luncheon table about half-past two. The party returned to the Conference, with the exception of Sir James Fergusson and myself. Sir James, being a Director of the Royal Mail Steamship Company, had an engagement with its local representative, Captain Constantine.

"A few minutes before three I left the Club with the Hon. Mr Cork. We drove to the post office, where $I$ had an interesting interview with the acting post- 
master, the postmaster being ill. I then visited the Supreme Court, and saw Sir Fielding Clarke on the Bench, and accepted an invitation to dine with him and Lady Clarke that night. They were old friends I knew in Hong-Kong.

"Leaving the Supreme Courts I called at the leading tobacco manufacturer in Kingston. He presented me with a few cigars, and asked me to see the process of manufacture in the basement of the shop. I declined. Next day he congratulated me on not going, for 40 of the I20 employees were killed two minutes after my visit.

"I went up the main street from the post office with my friend, and I saw thousands of people, men, women, and children, jumping pell-mell into the streets. I felt a singular shock, which they more readily detected to be the first indication of an earthquake.

"A moment afterwards the earth rose and fell up and down. There was an upward and downward movement with shaking, but no swaying. For an instant we did not realize what had occurred. Then another great shock came, and a huge building, three storeys high, fell right across the street a yard in front of me. I looked round and saw another building falling across the street just at my back, and the building on my left-hand side also came down with a crash.

"I took refuge with my friend on the right-hand of the street, but the whole place was in darkness for five minutes. The air was full of huge quantities of dust and mortar, and everything was perfectly black. When it cleared away I found myself looking like a black man.

"A most awful sight met my eyes. We climbed over the ruins of the buildings blocking the streets, and we saw the population that had escaped from the houses on their knees crying. Mothers were hugging their little children and weeping. People were rushing 
wildly about looking for their relatives. Others were on their knees, some lying prone on their faces, crying to Our Lord to be merciful and save them. I helped to drag a few people from under the ruins, and then made my way to the Club.

"To my dismay I found it was almost demolished. The roof had fallen in, and the dining-room in which we had lunched was a mass of ruins, being full of bricks and stone. Then I met a young fellow, hatless and coatless, with a handkerchief tied round his head. I could not at first make out who it was talking to me. Something then struck me, and I asked, 'Are you Gerald Loder?' and he said, 'Yes.' Of course he was a very old friend of mine, having sat with me in the House of Commons for several years. $\mathrm{He}$ took me round to the back of the building and showed me a poor fellow who had been pinned under a huge pillar. It was impossible to extricate him. His young and pretty wife threw herself on his dead body and embraced him. She was gently raised, but her dress was covered with his blood. Her reason had fled, and the utterances of strong men were choked in trying to express to her their sympathy. Three days after the poor lady, a great favourite, had not recovered.

"At the same time, on the parapet of the second floor, we saw the oldest member of the Club. We assisted him down with a ladder. He, like Mr Gerald Loder, had been writing in the writing-room when the roof fell in. Mr Loder's escape was marvellous. The chair in which he was sitting saved his life. The roof fell in and by some means his coat was pinned to the chair, and he could not get out without leaving his coat behind.

"Another remarkable incident took place. A lady passenger in our steamer had gone to her dressmaker's to have a new dress tried on for the Governor's Ball. It was on the second floor of the dressmaker's, and she 
had just got off the old dress to have the new one tried on, when the earthquake took place. She jumped through the window into a tree, and thus saved her life. The dressmaker was killed.

" Most of our party, all Members of Parliament, with the exception of one, were at the Myrtle Bank Hotel. It was lucky I did not go. I believe nearly 20 people were killed there.

"That night I made my way to Constant Spring Hotel, a few miles out of Kingston. The scene there beggared description. The ladies, who had been taking their afternoon rest, rushed out into the open wrapped in blankets or anything they could get hold of. I managed to get my baggage from my room, the roof of which had fallen in, and we slept in the open air that night without any covering. Next to me was Mr Arnold Forster, M.P., with his wife and boy. The hotel staff were very kind to us, and kept bringing tea and fruit to us during the night.

"It was a long night. An hour before dawn, about four o'clock, I saw a most beautiful sight. Just above the line of fire, which was distinctly visible blazing all night at Kingston, was the Southern Cross, standing like a beautiful sentinel over the stricken city with its thousands of homeless people. It was a most impressive and touching sight. I have seen the constellation of the Southern Cross in Australia, but I had never before seen it looking so sadly beautiful as this.

"Next morning I drove into Kingston and saw the true extent of the destruction. An extraordinary spectacle was presented by the inner walls of a house being left standing, the outer walls having fallen away; and on every wall could be seen pictures, potraits and paintings, making a curious feature amid the scene of desolation, yet so painfully eloquent of the ruin that had been wrought among the homes of the people. 
" When I got to our ship, I found 220 patients who had been brought on board from the shore. All night long the ship's doctor-a wonderful young fellow-had been taking off limbs and attending to the injuries of the wounded. Seventeen dead people were carried from the ship, which has been well described as a 'shambles.' The whole of the decks were covered with blood. And this is the ship the Americans complained so bitterly that the captain would not allow them to take refuge on. We ourselves were not allowed to go on board; we had to go inland and camp out in the open. We did not know until the day after we left that five seamen were buried in the ruins, although it was known that four of our passengers who went out with us and were to return by the ship had met their deaths.

"The Governor, Sir Alexander Swettenham, was all the night long among the wounded; and his wife, a most magnificent woman, was at the temporary hospital making tea and soup, and preparing bandages for the injured people.

"Some American war-ships came into the British harbour at Kingston immediately after the earthquake. My oldest friend once said to me in Australia, "Would you rather have in your employ a fool or a rogue?' His Excellency the Governor of Jamaica would probably answer-the latter, to-day. Sir Alexander had been working night and day for 48 hours, and threw himself down to sleep for a few hours on Thursday morning after the earthquake. It was while he was asleep that his police inspector invited or accepted the invitation of the American Admiral to land an armed force in Jamaica. You may imagine the horror of the Governor, knowing the feeling-unjust feeling certainly-prevailing among the poor, ignorant people of Jamaica, at finding what had been done and how the action would be misunderstood. He hurried to the Admiral and explained the situation. 
The Admiral said his honour was also concerned, and to satisfy their consciences or save their 'faces' it was agreed to withdraw the armed force in two hours. But in addition to this, letters were written, unwise letters, and letters never intended for publication, and I have no excuse for them. But this I know, there would have been a riot among the negroes if the American armed force had remained on land for 48 hours. It is most deplorable, and I am heartily glad peace was made with the United States authorities, who, I believe, have no designs on our possessions in the West Indies."

Lady Henniker Heaton was in England at the time of the earthquake, and her anxiety was truly great until the welcome cable reached her from Jamaica: "Safe and well." On the return of the "Port Kingston," she went down to Bristol to meet her husband in the early morning. Many of the passengers carried in their faces the memory of the terrible scenes they had witnessed, and some of them returned having left behind all that was dearest to them on earth.

Shortly afterwards, $H$. H. received a post card from a friend giving the biblical account of an earthquake, and asking if it tallied with his own experience. It was identical: "A great and strong wind rent the mountains and brake in pieces the rocks: and after the wind an earthquake: and after the earthquake a fire: and after the fire a still small voice." There was something mystical in the utter stillness of the night of the earthquake when they lay awake under the stars. Something not of the earth, when a prophetic ear might yet have heard the "still small voice." 
H. H. had some strange stories to tell of the curious sights he had seen. Like all great tragedies it was not without a touch of comedy. One little incident will serve. It happened that immediately before the earthquake the proprietor of some hotel had taken the manager into the garden and given him a month's notice. No sooner had the words, "I shall not require your services any longer," fallen from his lips than the entire building collapsed in a heap. "Evidently not!" replied the manager, beneath a pile of debris.

In I9Io, H. H. and his family broke fresh ground by visiting South America-that modern Tod Tiddler's ground where men may pick up gold and silver even unto this year of grace. The reasons that guided this choice were rather amusing. H. H. had been greatly diverted by hearing one of Kipling's songs.

"Oh, weekly from Southampton
Great steamers white and gold,
Go rolling down to Rio
(Roll really down to Rio),
And I'd like to roll to Rio,
Some day before I'm old ... ."

When therefore the doctor who was attending Lady Heaton made a tentative suggestion of a winter voyage in South America, it was hailed with enthusiasm. Sir Owen Philips, the Chairman of the Royal Mail Steamers-best and kindest of friends and most popular of Members on both sides of the Housesmoothed the way, and one rainy morning $\mathrm{H}$. H. set sail in a "great steamer white and gold" for South America. The mixture of nationalities on board baffles description. There were men from every corner of the globe; all bent on doubling or tripling their not 
inconsiderable fortunes. There was a fair sprinkling of youthful-looking Scotch engineers, who appeared to be drawing princely salaries until one understood something of the cost of living in South America.

Rio Harbour proved all and more than its admirers claimed for it. It enabled $\mathrm{H}$. $\mathrm{H}$. to join that fortunate company who can boast of having seen the three most beautiful harbours in the world-Sydney, Yokohama, and Rio.

In Buenos Ayres, H. H. and Lady Heaton were entertained to luncheon at the Jockey Club by $\mathrm{Mr}$ Hicks Beach, the First Secretary at the British Legation, a nephew of the famous Chancellor of the Exchequer. It was a much harassed Postmaster-General, bombarded by "reforms" by $\mathrm{H}$. $\mathrm{H}$. on one side, and refused supplies by Sir Michael Hicks Beach on the other, who described himself as between the devil and the deep blue sea. "I refer to the Right Honourable the Chancellor of the Exchequer as the sapphirine ocean." During his short stay, H. H. had very little time to explore the country; but he was much impressed by all he saw and heard of its prosperity. Naturally, he found many points of comparison between the pastural and agricultural aspects of South America and Australia. For the emigrant with no capital but plenty of energy he thought Australia offered the best prospects, but for the man with some capital to invest he thought the Argentine would yield quicker results.

As I have said, it was H. H.'s custom to visit Australia every few years, spending any time between three days and three weeks in Sydney. The mailboats always stop at least twelve hours at Ceylon, 
and to Ceylon he always returned with the greatest enjoyment. The exquisite beauty of the island was a favourite theme of his. He felt it an injustice that the gentle brown creatures who ministered in so excellent a fashion to one's comfort should be described in the well-known hymn as "vile."

On his last visit to the Island, $H$. H. and his daughter lunched at Government House with the newly appointed Governor, Sir Robert Chalmers, who had invited an interesting party to meet them. After luncheon Sir Robert showed them a beautiful banyantree in the garden. The banyan-tree throws out downward shoots from its spreading branches, which take root in the ground and support the parent tree in its old age. Sir Robert told his guests that this was always shown to little Cingalese children as an example for them to follow.

They returned on board with great armfuls of exquisite smelling temple-flowers, and masses of scarlet blossom from the gardens of Government House.

On this last visit, H. H. greatly missed his friend, Sir Hugh Clifford, who after distinguished services in Ceylon had been transferred as Governor of the Gold Coast. Some time before H. H. had had the pleasure of meeting Lady Clifford, formerly Mrs Henry de la Pasture, and always spoke regretfully of so much brilliance and charm being lost to England.

It has not been possible to enumerate the many voyages $H$. H. made backwards and forwards to Australia; but after the trip just mentioned he received a letter of congratulation from Joseph Chamberlain : 
Dear Mr Henniker Heaton,

You must have had a most interesting tour and I congratulate you on having the time and spirit to undertake it. I thank you for carrying the messages of goodwill to me from my colonial fellow subjects. I do, as you say, feel very much their kindness, which in present circumstances is even more welcome than usual.

I am still getting better and my medical advisers assure me and themselves of my ultimate ability to take my share of work, but for the present I must still keep out of public life and take an amount of rest which may be good for my illness, but which is certainly very hard upon my stock of patience. Later on I will let you know how I proceed and I hope that I may see you and other friends whom I am at present rather keeping back, as I so far trust the assurance of my doctors that I believe in a comparatively short time I shall be much better than I am now.

Yours truly,

J. Chamberlain.

During H. H.'s voyages to and from Australia, Marconi very generously placed at his disposal the wireless service on board. Every morning the news of the world was flashed across the great ocean, and at breakfast the daily bulletin was laid on H. H.'s plate:

On the morning of April I7th, I9I2, while in the Indian Ocean, the terrible news of the disaster to the "Titanic" was received: 
NEWS MESSAGE.

The Marconi International Marine Communication COMPANY, LTD.

R.M.S. "MALOJA."

I7th April IgI2.

News received direct from Fremantle Station.

A message received from Halifax says:

The "Titanic" is entirely lost

The s.s. "Virginian" reports that although she was called by Wireless she arrived too late

The s.s. "Carpathian" has picked up life boats containing 675 passengers

It is generally conceded that there are no survivors other than the 675 as first reported

Estimated death roll 2403

For such lives as were saved the undying gratitude of two nations went out to Marconi. His marvellous invention enabled the devoted heroism of the Marconi operator, Mr John Phillips, to send out cries for help from the sinking ship, which were heard and answered by the s.s. "Carpathian" and other vessels.

It was during H. H.'s visit to Sydney in IgI2 that a presentation was made to him of an illuminated address and a gold and silver inkstand mounted on Australian blackwood. The lid was inlaid with penny stamps of Canada, New Zealand, India, New South Wales, and South Africa; beneath this there was the inscription : "Presented to Sir John Henniker Heaton as a souvenir from the citizens of the Commonwealth of Australia."

The address was as follows: 




\section{PRESENTED}

TO

Sir John Henniker Heaton, Bart.

DEAR Sir,

We, the undersigned citizens of the Commonwealth desire to express to you our sincere congratulations for the long, arduous, and heroic fight you have made for Imperial Penny Postage throughout the Empire.

From your first speech in the British Parliament in I886 till the adoption of Penny Postage in the Commonwealth last year, you have never failed or flagged in your unselfish devotion to this great principle.

You have had to fight against vested interests, prejudices, and apathy, and have often stood almost alone, but now, having triumphed, we thank you for your magnificent work.

Your name will be associated with our postal system in the future along with that of Sir Rowland Hill, and it will shine ever more brightly as the generations of men come and go.

We are glad the British Government has recognized the merit of your great services, and has granted you a Baronetcy in your life, as too often our greatest reformers are only recognized after death. That you may be long spared to enjoy the honour so nobly won is the desire of

$$
\text { Yours faithfully, }
$$

\section{DENMAN,}

Governor-General of Australia.

In reply to a letter from $H$. $H$., describing his enjoyable visit to Australia, Lord Jersey wrote, from Middleton Park, Bicester, November 3rd, I9I2: 


\section{MY DEAR SIR JOHN,}

A letter from you rouses many pleasant recollections, and increases my regret that I cannot join in those cheerful chats and stories at the Carlton Club with their soupçon of lively spices. I am getting on fairly well, but have to avoid much exertion.

People go such a pace nowadays-I am not alluding only to motors-that it requires more strength and energy than I possess to keep up with them.

One thing is quite certain-that your work will never be omitted from the record of human development, and even the appreciation of Dukes and Cardinals will not outweigh that of the masses of humble people who have derived benefit therefrom.

You will be interested to know that my younger son has just visited Australia, and I am much gratified by the kind way in which he has been welcomed by my old friends. It has greatly touched Lady Jersey and myself.

We realize once more the warmth of Australian hospitality and friendship. Now I hope that you are getting on well and that you and Lady Heaton are in good health.

Yours sincerely,

JERSEY.

In May I9I3 H. H. made his last voyage.

The voyage to Australia out and home was achieved without any special incident to mark it. At Adelaide he took a final leave of his old friend Sir Samuel Way, Chief Justice and acting-Governor of South Australia. To all who know Sir Samuel Way, it is unnecessary to add any praise of his unfailing kindness and goodness of heart. Although Sir Samuel was only just recovering from a serious illness, he insisted on meeting $\mathrm{H}$. $\mathrm{H}$. and Lady Heaton at the station and driving them to his house. At luncheon he told a story of his favourite 
little step-grandson. Madame Melba was expected to tea, and before her arrival Sir Samuel explained to the little boy that he was about to see the greatest singer in the world, and he must be very good and quiet. Little five-year-old replied, "I don't care, I don't want to see her and I shan't be good." Shortly after this Madame Melba arrived and wishing to please the children she sang a few golden notes. She had not got very far when she was interrupted by a small boy standing in front of her and peering down her throat. "Have you a bird in your froat?" he inquired anxiously. Madame Melba declared this the prettiest compliment she had ever been paid.

In Sydney $H$. $H$. watched the arrival of the Australian Navy as it steamed majestically into Sydney Harbour, where Admiral Sir George Patey took over the Command of Australian waters from Sir George King Hall.

The town was en fête and a magnificent ball was given to the fleet by His Excellency Sir Gerald and Lady Edeline Strickland. A reception was given in the Town Hall to the officers of H.M.A.S. "Sydney," commanded by Captain John Glossop, which was the occasion of the presentation of a beautiful ship's bell from the citizens. Sailors are notorious for the shortness of their public speeches, and Captain Glossop's reply was no exception. He spoke of the sacrifices Australians had made for their Navy. "Some have given their sons, some have given their daughters, but you have given us the belle of Sydney."

How little anyone thought that the "Sydney" and her captain would so soon see active service and gain the undying distinction of sinking the "Emden."

The visit of the British Parliamentary party was 
another opportunity for rejoicings and the Governor gave a ball, the brilliance of which surpassed if anything the other.

H. H. left Sydney in November I9I3, and he and Lady Heaton went on to the South of France for the winter. From Nice he was recalled to London for the duty of giving his younger daughter in marriage to Major Adrian Porter, King's Messenger.

At the wedding, his old friends were delighted to see him looking so well after his long absence from England; and he spoke of wintering the following year in the West Indies-but when the time came he had taken the Last Voyage of all. 


\section{CHAPTER VII}

\section{AS A HOST}

"If thou be made the master of a feast lift not thyself up but be among them as one of the rest-take diligent care for them and so sit down.

"And when thou hast done all thy office take thy place, that thou mayest be mery with them and receive a crown for thy well ordering of the feast."

Ecclesiasticus.

A

CCORDING to "Who's Who," "playing chess and collecting books" were H. H.'s forms of recreation; but both these were as ing. To see his friends and make them known to his other friends at a luncheon, dinner, or breakfast-party was a never-failing source of joy to him. His breakfastparties after a morning swim at the Bath Club were almost an institution, and he had scant patience with lie-abeds unequal to such exertions. It was in vain a certain famous K.C. brought statistics to prove that " 90 per cent. of the prisoners in our jails spring from the class that habitually rises before 8 a.m.," and that, on another occasion, Dean Wace of Canterbury, refusing a breakfast invitation, shook his head, quoting reprovingly, "Early risers are conceited in the morning and stupid in the afternoon."

At one of these breakfast-parties Mark Twain told a curious story. The talk had been of " coincidences," and Mark Twain spoke of an adventure he had experienced as a young man. He was walking in some town, when he espied what he called a " peach 
of a girl." Being very young and very ardent, he followed her at a respectful distance to see where she lived. Almost immediately she turned into a house and the door shut behind her. Mark Twain felt he must make some excuse to see her again or find out something about her, so plucking up courage he rang boldly at the door.

It was opened by the young lady herself.

"Does Mr John William Gregory live here?" asked Mark Twain, inventing the first name that came into his head.

"Yes, he does," was the unexpected answer.

"You don't say!" ejaculated Mark Twain, as he fled from the house in a frenzy of astonishment.

It was once H. H.'s fortune to be chairman of a dinner given to his friend Mark Twain. By some curious mental aberration the guest chosen to propose the health of Mark Twain made a long speech lasting half an hour and finally sat down, having never once mentioned his name. Mark Twain rose to reply :

"Gentlemen, I'm very sorry I've only brought one speech with me to-night, and as it doesn't seem to suit the occasion I guess I'll sit down. I made sure that gentleman was going to say what a fine fellow I was and how honoured you all felt at having me and that America should be proud of her son; and in reply I was going to say I was quite overcome by such praise, far, far exceeding my deserts, and I was a modest man, and he had made me blush, and I should never forget his words and carry them back to America in my heart, and so on. Well, gentlemen, I can't think up another speech in a hurry, and speaking for myself, I'm very sorry not to deliver that one, because it was a real good speech and you would have liked it.' 
This impromptu was greeted with roars of laughter, and any awkwardness that might have been caused by the contretemps was entirely swept away by Mark Twain's bonhomie.

"I have dined in all quarters of the world: I have eaten clam and canvas back in New York, I have sipped Sake' in Tokio, I have munched junk at sea and drunk debatable water in the tropics," wrote H. H. describing his experiences ; and again, "Dining as a fine art concerns rather the ear than the tongue," which is after all exactly what the witty old lady meant when she said, "It isn't the menu that matters, it's the men you sit next to."

The ideal dinner was a subject $\mathrm{H}$. $\mathrm{H}$. was fond of discussing, and he embodied his views in a light essay, wherefrom the gourmet will learn little but the lover of good company find much food for thought.

"A company of mutes hired to mourn over the joint and bird," was a description that could never be applied to one of H. H.'s parties, and it is pleasing to feel that such obsequies have become almost a thing of the past. I have said that H. H. was not a good platform speaker, but he had a very happy gift of afterdinner speaking and some rare flash of wit or anecdote could be counted on. He was Vice-President, if not President, of a club formed for the purpose of limiting speeches to ten minutes, whose members, be it said, were greatly sought after.

Sunday luncheon-parties in Eaton Square brought together such pleasant company as went far to attain Disraeli's concept: "A little dinner, not more than the Muses, with all the guests clever and some pretty."

In the old days, when Lord Russell of Killowen was a constant visitor, his brilliance and rich store 
of anecdotes alone made such gatherings memorable. Another Irish Chief Justice, Lord Killanin-better known as Judge Morris-famous for his stories and brogue, shed his wit at these parties in a manner never to be forgotten. It is regrettable that the telling of anecdotes has somewhat gone out of vogue, and the younger generation will never know how such jewels sparkled in the hands of the lapidary. Who having heard can forget Lord Killanin telling his inimitable tales of legal life, among them the story of a poor Irishman about to be tried for moonlighting and his indignation when his counsel asked him what defence he wished to make? "An' is ut a difince ye'd be afther havin' me make? Shure an don't I be tellin' ye the foreman of the jury is me cousin Mike O'Gradybegorrah, that's me difince!"

A breakfast-party in the House of Commons on Coronation morning was an unusual form of entertainment. Host and guests in full levee dress at that early hour made a remarkable spectacle, which was further accentuated by peers, trailing clouds of glory, hurrying across to the Abbey. After breakfast Marconi and $\mathrm{H}$. $\mathrm{H}$. were photographed together on the Terrace by Sir Benjamin Stone. The portrait appeared in the Italian papers with the inscription: "His Majesty King Edward of England and Signor Guglielmo Marconi."

H. H. " liked a link," and felt a genuine pleasure when he found himself introducing two friends, "Body" and "Soul" by name, and thus forestalling the Last Day; and again when he had two Crimean veterans at the House, and introduced Colonel $F$. to the late General Sir Harry Rhodes Green with a cheery, "Well, I suppose you last met in the trenches before Sevastopol!" And so they had! 


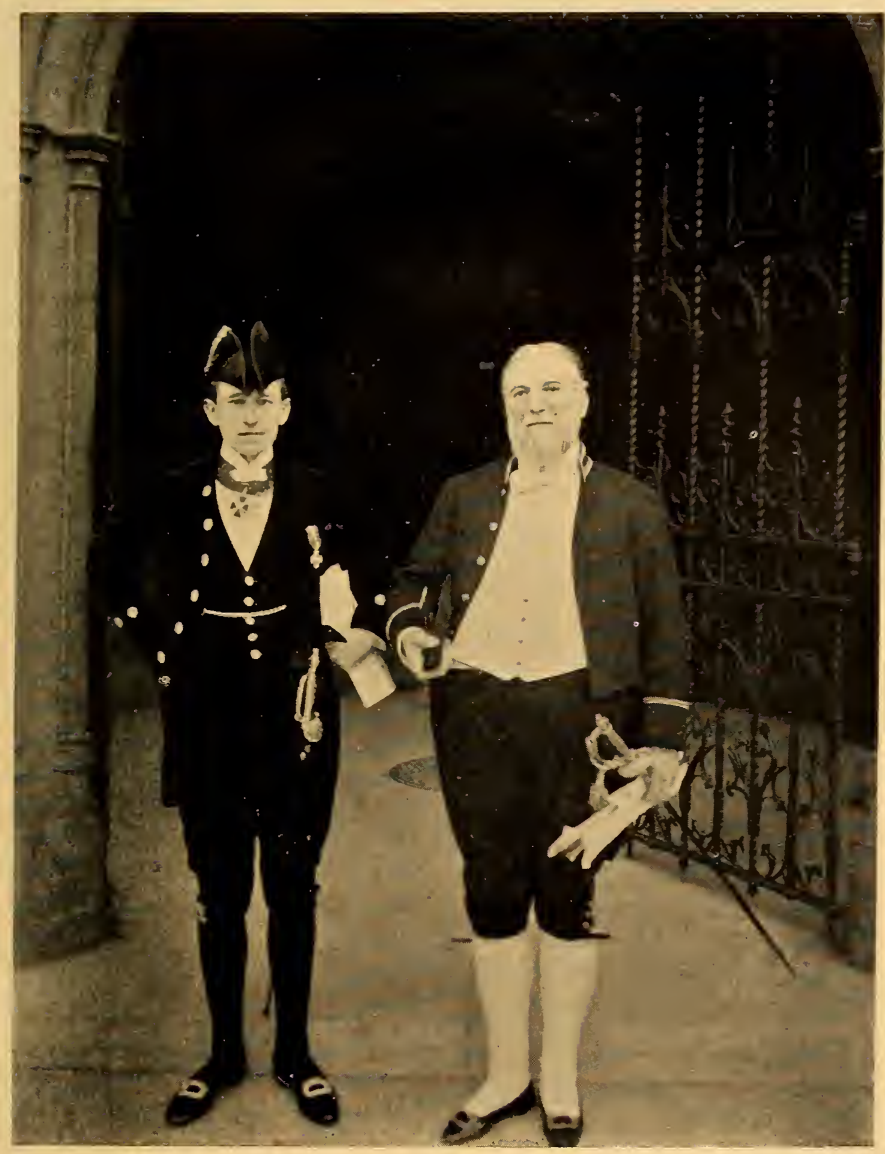

H.H. AND MARCONI ON CORONATION DAY, I9O2, AT THE HOUSE OF COMMONS

Photograpli by Sir Benjamin Stone 

When the summer-time came, H. H. was always one of the first to give tea on the Terrace, and almost every day throughout the season he would give delightful informal parties. The Terrace of the House has rightly earned the reputation of being the coolest place in London, and a fresh breeze may be found there on the hottest days of June.

There was one especially amusing afternoon when the American Ambassador, Mr Whitelaw Reid, and his daughter, Mrs John Ward, brought Mr and Mrs Nicholas Longworth-the latter better known as Miss Alice Roosevelt.

Directly she came on the Terrace, H. H. took her aside and said :

"There is a very grave matter I think it right to mention to you before taking tea. You know we never form a Government in this country without putting an American girl in it-for instance, Mrs Chamberlain, Lady Harcourt, and the Duchess of Marlborough. Well, all patriotic people in the country hoped and believed you would have put aside your own selfish love matters, and married $\mathrm{Mr}$ Balfour. With your father as President of the United States, and your husband as Prime Minister of Great Britain and Ireland, peace and goodwill would be assured. In place of that you have neglected a great patriotic duty."

Mrs Longworth pretended to look deeply perturbed :

" Oh, dear, I never thought of it," and whispered, as she glanced towards her husband, "Is it too late?" tea."

H. H. replied : "We will see. However, come to

He placed her next her old friend Mr Marconi, who had of course seen a great deal of the Roosevelts on his various visits to America. 
The moral of H. H.'s lecture was gracefully pointed by the arrival of $\mathrm{Mr}$ Winston Churchill, the brilliant son of a brilliant American mother, and a great English statesman. Strawberries and cream were handed round, and after tea there were beautiful roses for the ladies as the party broke up amid laughter and pleasant chatter.

$\mathrm{H}$. $\mathrm{H}$. very greatly enjoyed the informal gatherings which took place at Carlsbad, where he went yearly for the cure. One day the talk turned, as was not unnatural, on Postal Reform. H. H. told his listeners that he had always advocated a measure enabling the writer of a letter to get it back before it was delivered if he could prove to the postmaster that he was the writer.

H. H. instanced a case of a friend of his who had inadvertently posted a letter, from abroad, to his wife, which contained expressions of very warm regard and was really intended for a lady he had recently met. Realizing his mistake, he hurried to the postmaster to get the letter back but was met with refusal. In a great state of agitation he telegraphed to his wife: "Have posted a letter to you by mistake, earnestly hope you will return it to me unopened as it would cause us both great unhappiness." H. H. asked his friend what had happened. "My wife was a brick," he said, " and sent back the letter, but it cost me a diamond bracelet to put it right with her !"

"I wonder," asked H. H., "what these ladies present would have done?"

Elinor Glyn said she would write a book with two endings, showing what would happen if the letter was returned and if it was opened.

"I would send back the letter unopened, but it 
would br-reak my heart," an Italian lady gave her views prettily.

" Of course I should open it, and so would every one else!" an Englishwoman said.

"I might send the letter back, but I guess I'd use a steam-kettle first," an American girl said.

Father Bernard Vaughan, who was also present, was petitioned to preach a sermon on the right thing to do under the circumstances.

Father Bernard Vaughan was to be met at Lady Doughty's luncheon-parties in Buckingham Gate, where the conversation was always full of wit and good-humoured badinage. One day there was a young guardsman present who was obliged to leave early in order to catch a train down to the country. $\mathrm{He}$ was greatly alarmed at the possibility of losing the train and bade farewell to his hostess in much perturbation. Father Bernard Vaughan turned to Lady Doughty :

"I hope that young man is as concerned for Eternity as he is for Time."

$\mathrm{Mr}$ Marconi was one of $\mathrm{H}$. H.'s closest friends, and they saw each other almost daily for many years. H. H. stood as godfather to pretty little Degnia Marconi, and was a great admirer of his fairy-like little goddaughter.

Some years ago $\mathrm{H}$. H. and Marconi were dining at the Savage Club, and were greatly entertained by some "imitations" of well-known actors given by one of the members. In particular they were struck by the perfect imitation of Sir Herbert Tree as Richard III, who in his well known fits of absent-mindedness occasionally passed his hand across his brow, inquiring: "What play is this? Ah, yes, 'Richard III'; ah, thank you." 
When the imitations were over $\mathrm{H}$. $\mathrm{H}$. thought it would be amusing to go off to see the original, so he and Marconi drove to the Haymarket. Between the acts a note came round asking them to go to Sir Herbert's dressing-room, where they had a most interesting and witty talk, which was interrupted by a loud knocking at the door by the call-boy. Sir Herbert turned to Marconi with his familiar gesture.

"Tell me," he said, " what is the play?"

" "Richard III,'” replied Marconi.

"Ah, thank you, thank you," said Sir Herbert, as he made his farewells.

H. H. had a great many friends among dramatists and musicians. Sir Arthur Sullivan, who was dining with him one night, amused the company by describing a recent tour through America where one town turned out en fête to welcome him. The streets were decorated and he was met by a band. He felt extremely flattered at receiving such a welcome in the Wild West, until he learnt that he had been mistaken for Sullivan the prize-fighter, "the Sullivan" as the local editor put it.

In those days it was a popular saying that Sir Arthur Sullivan could never remember the numbers of his friends' town residences but always told the cabman: "I don't know the number but the doorknocker is B flat."

Colonial Governors were frequently among H. H.'s guests at the House of Commons, and he enjoyed nothing more than listening to the news they brought of the political and industrial progress of our farflung dependencies.

One night the late Duke of Argyll, ex-Governor of Canada, and Lord Ranfurly, ex-Governor of New 
Zealand, were among a small party, and as was perhaps not remarkable under the circumstances the talk turned on the preponderance of people of Scotch descent in those two colonies and the number of high offices held by Scotchmen.

"I yield to no one," said H. H., " in my respect to Scotland, but I have felt compelled to join the Royal Society of St George of England in order to protect our own interests. In this House of Commons we have Scotchmen as Prime Minister (Campbell Bannerman) ; Leader of the Opposition (Balfour) ; First Lord of the Admiralty (Tweedmouth); First War Lord (Haldane) ; and President of the Board of Education (M'Kenna). All the leading bankers are Scotchmen, and most of the great ship-owners."

The Duke of Argyll as a great Imperialist had given his continuous support to the agitation for Imperial Penny Postage ever since I887, when he wrote: "I hope you will hammer away at the project, and I believe you will find it ultimately adopted."

When, in I905, H. H. again approached the Duke on the subject of Universal Penny Postage the project did not enlist his sympathy, and he replied:

\section{My dear Mr Henniker Heaton,}

No. I don't want to kiss all the world.

The Empire is enough for me in the matter of Penny Post.

Believe me,

$$
\begin{aligned}
& \text { Yours truly, } \\
& \text { ARGYLL. }
\end{aligned}
$$

Poets, painters, and novelists were all made welcome at H. H.'s hospitable table ; in fact, anyone of distinction in any walk of life was sure to be met there 
sooner or later. His dinner-parties at the House of Commons were always rather informal affairs, and his table had a way of expanding in a telescopic fashion as the dinner proceeded.

Young hostesses given to panic by the nonappearance of expected, or appearance of non-expected guests, might well learn a lesson from Lady H. H.'s undisturbed serenity when met in the Lobby with the information that "the Chinese Minister is coming, and an Arctic explorer, and the PostmasterGeneral said he would come if he could, and also some friends whose names I cannot recall at the moment!"

It was never H. H.'s way to make elaborate plans for the right people being asked to meet each other, but such was the force of his genial personality that the most incongruous company would meet together and exchange views with the greatest cordiality.

Mr Justin M'Carthy's reply to an invitation given in IgIo:

My deAR, DEAR OLd FRIEND, HENNIKER HEATON,

I could not tell you how much I feel touched by your most kind invitation and how much sincere regret it gives me that I am not able to accept it. You will already have heard from my daughter the full explanations of the reasons why I cannot even think of becoming a guest at your proposed dinner in the House of Commons. There is no entertainment I should enjoy more than a House of Commons dinner, and there is no man living from whom I should welcome such a kindness more cordially. than from yourself. But Charlotte has told you that I have for many years lived as one absolutely withdrawn from social as well as from public life, and although I am getting on very well in my course of improvement, I have yet some dreary path of self-protection to plod along 
before I can hope to be a live man among the living. But I strongly hope that we shall meet again many times in this life, dear old friend and true friend, and interchange genial memories and consequences.

Ever, my dear Henniker Heaton, Your old friend and comrade, Justin M'CARThy.

It was always a pleasure when the late Mr Moberly Bell-manager of "The Times" - could be persuaded to join H. H.'s parties. His massive head with the penetrating kindly eyes gave him an appearance which did not belie the great intellect, courageous and just, that governed "The Times" for so many years. When released from the cares of office, his humour and gentle irony made him the most popular of guests. He arrived late for dinner at the House one night, having been sitting on the Commission for amending the Divorce Laws. In the middle of the proceedings it seemed that Lady Frances Balfour had handed him a sheaf of papers saying :

"Please take care of these for me, I haven't a pocket."

"What!" exclaimed Moberly Bell in a loud voice. "You haven't a pocket and you want a vote -God bless my soul!"

H. H. spoke of his interest in the Divorce Commission, as some years previously he had caused to be issued a Parliamentary paper giving the laws of Marriage and Divorce in all countries of the world. The paper showed that the cheapest country in which to get married was Belgium ( $2 \frac{1}{2} \mathrm{~d}$.), and the easiest place in which to get a divorce was Japan, where a husband could obtain his freedom if his wife talked too much. This came as rather a surprise, as it was 
generally thought the United States made the marriage laws the least binding. Wilfrid Meynell summed this up best in his oft-quoted lines :

\section{THE UNITED STATES 1}

"It really is a little odd

If marriage has been sent by God

Above our human Fates,

To see Divorces all the same

In that great Continent whose name

Affirms United States.

America, dear Continent,

If continent you be,

Why let a knot that's tied in heaven

Be loosed in Tennessee?

Be careful lest in mock you're given

The title of "the Free." "

If $\mathrm{H}$. $\mathrm{H}$. enjoyed telling a good story himself, he was not less appreciative of anyone else's, and his hearty infectious laugh was the best tribute. It was sometimes rather amusing to see the twinkle in his eyes when he listened to a friend "fathering" some little orphan anecdote.

Hardly a day passed without his being sought out by some unknown visitor from foreign shores anxious for introductions or some such help, and it is not too much to say that $\mathrm{H}$. $\mathrm{H}$. never in his life turned a deaf ear to any appeal if it was in his power to help in any way. "For many years it has been my settled conviction that Sir John was the most consistently kind-hearted man I ever met in my life. I have met many benevolent people in my life," wrote Mr SneadCox, "but never anyone who was so ready as he was to take personal trouble to do a kindness to others."

1 From “ Verses and Reverses," published by Herbert \& Daniel. 
One day many years ago, when $\mathrm{H}$. $\mathrm{H}$. was in the Carlton Club, he was told a strange-looking man was asking for him on important business. $\mathrm{He}$ went down to the hall and was told a truly surprising tale of adventure by the stranger, whose name happened to be Louis de Rougemont. H. H. immediately sat down and scribbled the following note to Sir George Newnes :

\section{My DEAR NEWNES,}

I am sending you the most interesting man in the world or the biggest liar in the universe-in either case he will be equally useful to you.

\section{Yours,}

H. H.

Two hours later back came an answer from Sir George Newnes :

Dear H. H.,
You have sent us an angel unawares.

G. N.

The subsequent history of the Angel unawares is too well known to be rewritten.

Perhaps H. H. realized more fully than anyone how much heart-burning is caused by the neglect of English people to return the hospitality they have received so generously when travelling abroad and in the Colonies. This neglect is more often due to want of thought than deliberate intention. So many people imagine that some one else is sure to be looking after the visitors and they need not concern themselves on their behalf, but $\mathrm{H}$. H. would take personal trouble to make their visit as enjoyable as possible, not only by asking interesting people to meet them but by 


\section{II6 SIR JOHN HENNIKER HEATON}

doing his best to make sure that their services to the Empire were recognized in the right quarters. No one was more generous than himself in the appreciation of the work done by others, in distant unknown parts of the Empire-nor more alive to the fact of how easily these services are forgotten in the rush of London life. 


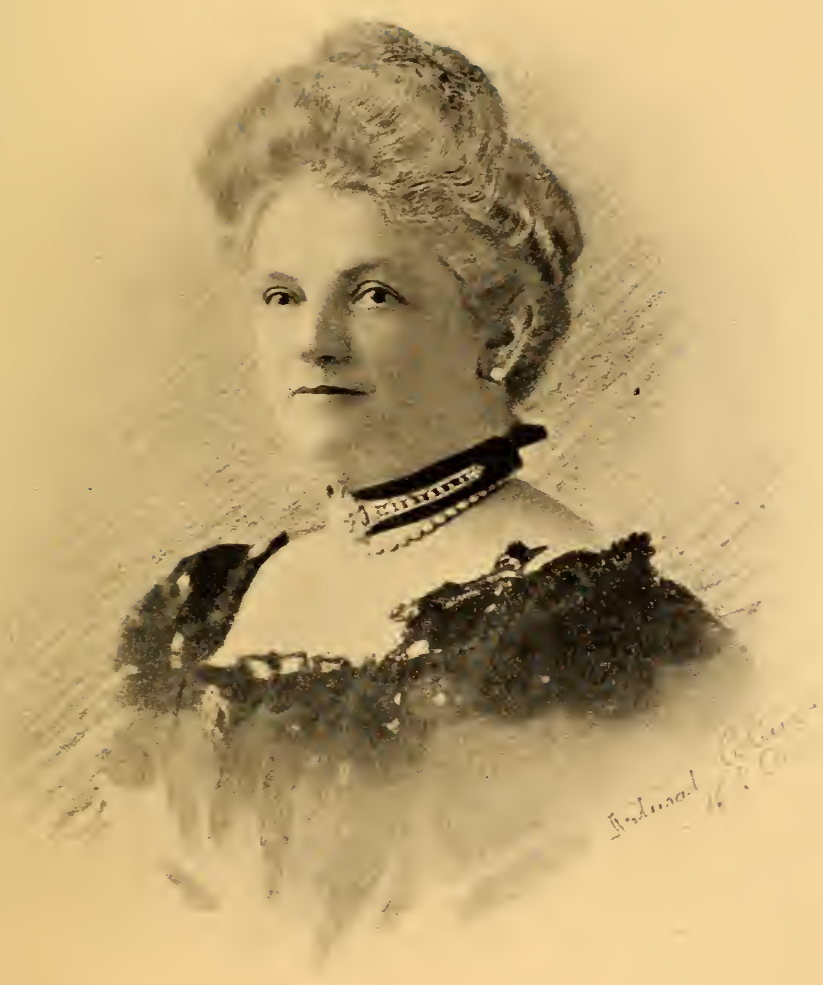

LADY HENNIKER HEATON 



\section{CHAPTER VIII}

AT HOME

7 HOUGH of necessity a great deal away from home, $H$. $H$. was devoted to his wife and children. $\mathrm{He}$ very much enjoyed home gatherings, and always took the keenest interest in the sayings and doings of each member of his family. The love that existed between $\mathrm{H}$. $\mathrm{H}$. and his wife, and his tender care of her during many years of delicate health, was very touching to witness. Theirs was literally a married life that had never known a shadow of a shade of discord as far as their mutual relations were concerned.

H. H. was always a sympathetic listener to whatever his children had to tell him, and those who knew him only as an impatient critic and antagonist would marvel to see the patience he brought to bear in listening to some childish recital of adventure. In later years, when his own family grew up, he transferred some of his affection to his small grandchildren. It was rather a charming picture to see the Postal Reformer, with his arms folded on the table, listening attentively to a small and incoherent grandson struggling with a "funny story."

"By Jove, old man, you astound me!" would be $H$. H.'s comment, when the little lad with bursts of glee had reached the climax of his old, old " funny story.'”

H. H., who had a remarkable memory in many 
ways, was never able to distinguish one flower from another. As a general rule, he used the generic term "roses" for anything that was brightly coloured. The nursery-party were considerably enlivened one day by the receipt of a picture postcard of some handpainted flowers. "My dear little Lily, I send you this card to remind you of your pretty namesakes." The flowers were violets !

$H$. H. was a great raconteur, even in his own home circle, and he took as much trouble to make a dinnertable story amusing when his wife and children only were present as he did when entertaining a party of celebrities. His Sunday luncheon-parties in Eaton Square were always very joyous and interesting gatherings. He knew well how to draw the best out of every one, and his enthusiasm for his guests' attainments was always sincere. Their bons mots were sure to draw forth the flattering tribute of that hearty laugh, which was always one of his greatest charms.

How heartily $\mathrm{H}$. H. detested all want of generosity in speech and feeling! The grudging praise, the belittling of achievements, the want of enthusiasm that froze all genial intercourse, would kindle the light of indignation in his eyes.

The condemnation of R. L. S. for such as

\section{“. . . moved among their race,}

And wore no glorious morning face"

would never have fallen on $\mathrm{H}$. $\mathrm{H}$., who loved the simple pleasures of everyday life. As the years grew upon him, never once was he heard to regret the past as superior to the present. For him To-day was the age of miracles and, if he expressed any regret, it was that he would not live to see the coming glories of to-morrow. 


\section{AT HOME}

H. H.'s method of working was the despair of many a secretary. Tidiness he abhorred, and was never happy until every chair in his library was piled high with books, the floor scattered with paper and his writing table a chaotic mass of literature. Sandwiched between postal complaints and parliamentary Blue books would be found various ill-spelt little letters written in childish scrawls beginning, "I have brok mine horse," which $\mathrm{H}$. H. could not be induced either to destroy or to keep in a more suitable place.

Serious young men who require the stillness and silence of locked doors when they set to work on some intricate problem would be surprised at the methods of the Postal reformer in his home. $\mathrm{He}$ would go to his library after dinner to write, let us say, an article for " The Nineteenth Century." Passing the drawing-room he would listen to the music for a few moments, and with a special request, "Please leave the doors wide open so that I may hear the singing," he would begin his assault on the blundering and plundering of the post office.

$\mathrm{H}$. H. was fortunate in attaching to himself, as well loved friend and secretary, Edward Cant Walla man of scholarly attainments and high character. Between H. H. and Edward Wall existed the most complete confidence and a depth of affection rarely found. $\operatorname{Had~H}$. H. lived to fulfil his intention of writing his memoirs, he would have included a high tribute to Mr Wall in grateful memory of his loyal support and valued services.

Four sons and two daughters composed H. H.'s family. His eldest son, John-the present holder of the baronetcy-married the Honble. Sermonda Burrell, daughter of Lord Gwydyr. At the time of 
the marriage, Sermonda Burrell had two grandfathers living, the fourth Lord Gwydyr, who reached the age of 99, and Sir John Banks, the Queen's Physician in Ireland, who lived to be 98. Lord Gwydyr was born in I8ro, and was present at the Coronation of George IV, when he saw the Hereditary Champion of England ride into Westminster Hall in armour and throw down his glove-this was the last time it was done. He was also present at the Coronation of William IV and Victoria, and was for thirty years Secretary to his uncle, Lord Willoughby d'Eresby, the Hereditary Lord Great Chamberlain, and lived with him in the House of Lords. Although not present at the Coronation of Edward VII, Lord Gwydyr received a telegram of roo words, answer prepaid, to know what was done in the robing-room at the last state opening of Parliament by Queen Victoria.

H. H.'s second son, Reginald, Commander R.N. married Mary, daughter of the late Colonel Houstoun of Clerkington. Herbert, Assistant Colonial Secretary of Mauritus, married Phœbe, daughter of the late Lindsay Talbot-Crosbie of Ardfert Abbey, Co. Kerry. Arthur, Lt.-Commander R.N., married Vera, daughter of the late Hamilton Atherley. His elder daughter, Elizabeth Ann, married Algernon Paget, son of Berkeley Paget; and his younger daughter, Rose, married Major Adrian Porter, King's Messenger, son of Colonel Morton Porter.

Occasionally, on Sunday evenings a family party would gather in the library, and $H$. H., while energetically striving to keep pace with his ever-growing correspondence, would keep his sons and daughters amused with extracts from the various letters he kept pulling out of his pockets. Sometimes an important 
paper would be missing, and then every one would be on their knees for an hour, emptying dispatch boxes, going through drawers, and generally looking in every likely and unlikely spot for the lost document.

In spite of H. H.'s vigorous efforts to answer immediately every letter, one would sometimes get overlooked. A reproachful reminder in poetic form made one more example of those "cradled into poetry by wrong " of whom Shelley sang :

Belton House,

GRANTHAM.

" Our Henniker above all others seeks

To make our Postal Correspondence better, And is it $\mathrm{He}$ who takes four mortal weeks

To answer one short simple urgent letter?"

HENRY CUST.

H. H. was very fond of poetry of all kinds, and loved to hear it read aloud if the reader had a sympathetic voice and good intonation. Talking of the voice, he always said that the late Canon Fleming was the best elocutionist in England, and he very much enjoyed hearing him preach at St Michael's, Chester Square. H. H. once found himself seated next to Canon Fleming at a big city dinner. The Canon had just pronounced grace in his low clear, musical voice, and had settled himself comfortably down to his turtle soup when a stray remark of H. H.'s caused him to spring from his seat, exclaiming, "Good gracious, I'm at the wrong dinner then!" and off he flew, followed by chuckles of amusement from his neighbours.

Sometimes on fine spring mornings, $\mathrm{H}$. $\mathrm{H}$. would leave his library early, and invite his daughters to 
come out with him and see some of the newest exhibitions of pictures in London: $\mathrm{H}$. $\mathrm{H}$ did not often buy pictures, as his great hobby lay in collecting valuable old books. He possessed some extremely rare editions among the three thousand books in his library in Eaton Square. His Australian books were most interesting, and those which dealt with nature especially so, as many of them contained life-size illustrations of birds and flowers of the Antipodes.

$\mathrm{H}$. H. was always delighted to take his daughters to any interesting social function, and in his popular company they could scarcely fail to enjoy themselves. Since no picture of contemporary social life is complete without an anecdote of the brilliant American ambassador, Mr Joseph Choate, a somewhat unsatisfactory little story may be forgiven. At the Royal Garden party His Excellency, after chatting with H. H., turned to his daughters and paid them the prettiest compliment that has perhaps ever been paid to debutantes. The elder girl turned to her sister and said, "We will never forget that as long as we live" -but from that moment to this neither of them has ever been able to recall what Mr Choate said!

It is but a melancholy satisfaction for them to feel that they were once the recipients of a yet more exquisite compliment than Sheridan's famous speech to a charming young lady: "Will you come into my garden, I would like my roses to see you."

For the greater part of his life $\mathrm{H}$. H. enjoyed the best of health, but his ceaseless activity imposed too heavy a strain upon his constitution, and in IgII he had a serious breakdown. A stroke of paralysis, due to overwork, gave cause for the gravest anxiety. Sir Lauder Brunton was called in, and gave warning that 


\section{AT HOME}

serious results would occur unless all work were put on one side for some months; with reasonable care and freedom from worry H. H.'s life might be prolonged for many years, but he would not be able to stand undue excitement or strain. A verdict that future events were to prove only too true. The long weeks of convalescence were very trying to $\mathrm{H}$. $\mathrm{H}$., in spite of the kindness of friends who did everything possible to cheer him. The word "Postage" was forbidden, and only light literature was allowed. His chief delight was in a number of books by Pett Ridgesent to him by a thoughtful friend-which he ever afterwards declared the best medicine for a sick man.

Like many others, H. H. found compensation in the midst of his trials. Every day brought some token of kindness or remembrance. Old friends from the Carlton Club came to amuse him with good stories, and the latest gossip. Messages and wishes for a speedy recovery reached Lady Henniker Heaton from both sides of the House of Commons, and "please say to him a number of our Members from Ireland join in this wish" wrote William Redmond.

A telegram from Sir Thomas Lipton offering H. H. a voyage in the "Shamrock" to recuperate was reluctantly declined, as involving too great a responsiblity for his host, though the kindness was deeply appreciated.

As the weather grew warmer $\mathrm{H}$. $\mathrm{H}$. was able to spend most of the day sitting under the trees in Eaton Square, and here by good fortune he found two little friends who beguiled the long hours as only children can do. Mercy and Mary Webbe, daughters of the famous cricketer, A. J. Webbe, were the centre of a party of children who met in the Square every morning and 
afternoon. Mercy was the first to make friends with H. H., her gentle sympathetic nature touched by any suffering. She would talk to him in her wise, gentle way for hours, and her clever, poetical thoughts were a constant source of marvel and delight to $\mathrm{H}$. $\mathrm{H}$.

Shortly afterwards Mercy went down to the country, and her little sister Mary came upon the scene. Mary at this time was about seven years old; a little flying figure, in a blue cotton frock under an enormous mushroom hat, sunburnt little face and hands, and the cleverest, wittiest, most mischievous and adorable little mite that ever came out of a fairy tale. She had a band of faithful followers, nearly all older and bigger than herself, whom she ruled with a rod of iron. Mary chose the game and Mary chose the part she would play and Mary awarded all the prizes and punishments. A born leader, she instantly recognized a kindred spirit in $\mathrm{H}$. $\mathrm{H}$. and they became fast friends.

H. H. had been ordered complete rest and quiet, but Mary cared for none of these things. When he appeared in the Square, she would fling herself upon him like a small whirlwind, shout down his ear, and seizing his walking stick-for he was still very lamedance away with it to the other end of the Square looking like an imp of mischief. She had a most astonishing vocabulary for her years, and would send H. H. off into roars of laughter by her quaint phraseology. "I would tell you and welcome, but you are not to be trusted," she would reprove him when he begged to be allowed to share her confidence. She was a little lady who fully realized her own worth. "Good-bye," she said one evening, throwing her arms round H. H. ; " you won't see me again, as I'm going 
away to-morrow." Then seeing his look of blank consternation she hopped round him in glee, crooking a tiny forefinger at him and crying, "I only said it to take you in-I only said it to take you in."

H. H.'s affection for his little friend inspired some rather charming verses :

\section{AN IDYLL OF EATON SQUARE.}

I.

Come into the Square, Marie, Come into the garden, do, For sadly your ex-M.P.

Has gazed at the gate for you.

II.

For under a branching tree,

He sits on a hard green chair, And turns for a small Marie,

Whenever two footsteps stir.

III.

Whenever a shrill young voice

Through railing and bush vibrates;

His look leaps up to rejoice

To watch where a blue skirt waits.

IV.

With mischievous eyes agleam,

And very brown hands outheld;

A laugh peels sharp as a scream

And peace from the day's dispelled.

v.

You were missing this morning, Marie!

Alone on the lawn, at loss,

Your neighbour, from under a tree,

Hied homeward to thirty and three,

Disheartened and cross. 


\section{CHAPTER IX}

\section{A PEN PORTRAIT}

T $\mathrm{N}$ painting a portrait, two thoughts are uppermost : first, that the picture shall be as entirely truthful as even Cromwell himself could desire; 1 and, secondly, that the mise en scène should express without overshadowing the subject. Annual visits to the Academy show certain learned gentlemen with a hand laid affectionately upon a globe, if the sitter is a traveller, or toying with a magnifying glass, if he is a professor of science. Any painter can thus portray the objects in which his sitter is primarily interested, but it takes a Sargent to dispense with such accessories and yet leave the impress of the man's mind shining through his eyes, and breathing his spirit through each stroke of the brush.

It has been my endeavour to show $\mathrm{H}$. H. not only as a Postal Reformer, but in all the phases of everyday life, and yet I am acutely conscious that his character, his inmost thoughts, remain but vaguely expressed. Perhaps his very simplicity and transparency make the task more difficult than if one were analysing a profoundly complex character.

For one who had travelled so extensively, and seen so many sides of life, his judgment of men was singularly uncritical. All his friends know the truth of the assertion that to his kindly mind " every goose was a swan," and having benefited so constantly and 
so agreeably through this mistaken conviction I feel peculiarly unfitted to criticize it.

Injuries were forgiven and forgotten with the setting of the sun, and the perpetrator merely became "that poor fellow," though less amiable members of H. H.'s circle could doubtless have found more suitable designations. Like all public men, H. H. had his enemies; but I think he had fewer than most. Some wise man once wrote you cannot be too careful in the choice of your enemies," but it is perhaps truer to say he who never made an "enemy never made anything else."

His large charity went out in the words of Ian Maclaren, whose books he dearly loved, "Be pitiful, for we are all of us fighting a hard battle." Still it must be recorded that there was one class of mind, for which he had no mercy-the obstructionistic, and of whose ultimate destination he, at least, had no doubt. Sheer laziness, the generating factor of an Obstructionist, can defeat and overthrow the best laid schemes of the greatest genius. To an Obstructtionist every philanthropic movement represents but an extra signing of documents, every Arctic or Tropical Exploration means only an extra search for a mislaid compass, or an order for a stores catalogue. "They have no imagination," $\mathrm{H}$. H. would say, implying utter and irrevocable condemnation. There was a curious phrase he would frequently employ when urging forward the Obstructionist faster along the "Primrose path of dalliance." "Show a little public spirit," was his formula, addressed indescriminately to governing bodies, taxi-drivers, lift-boys, and lesser fry who impede progress.

H. H. could differentiate between the individual 
and the corporate Obstructionism-the latter he held in some respect as a necessary evil used to combat hasty legislation. Ex-ministers and their secretaries will appreciate the following letter written by $H . H$. to Lord Blyth :

“. . . I am looking forward with great interest to the result of your deputation to the Chancellor of the Exchequer and Postmaster-General. I beg to warn you against the stereotyped replies which you and $I$ have been met with during more than a quarter of a century. Before the two great Cabinet Ministers begin to reply you will no doubt anticipate them by asking them not to put you off in the old and worn out way :

I. I recognize the importance of the deputation.

2. I fully sympathize with your objects.

3. Circumstances will not now permit.

4. We shall when the time arrives and opportunity permits."

H. H. had to an extraordinary degree a personality that might be described as magnetic. He realized that in order to get any request granted it was only necessary for him to see the person who was required to do that particular thing. $\mathrm{He}$ had the greatest faith in personal interviews and no faith at all in the written word that probably gets no further than an obstructionistic (once more!) secretary.

Literally, $\mathrm{H}$. $\mathrm{H}$. did not know the meaning of the word "No," and he took it from no one. With his mind centred on the achievement of some project, he would listen to arguments with an intolerance and impatience that belied his natural broad-mindedness. Too good a mathematician to be convinced by an array of figures, too keen an historian to learn from 
past errors, ${ }^{1}$ he held on his way regardless of every argument and every prophecy of failure.

His enthusiasm was one of his most noticeable traits, and his intense vitality showed itself nowhere more clearly than in the energy he threw into mastering whatever subject had aroused his interest. As a result, he was continually consulted on matters outside postal affairs by strangers who had heard of his wide sympathies. A letter advocating a project for treeplanting by school children would send him down to Kent with every offer of assistance; a note from a scientist concerning an invention for testing the eyesight of mariners would evoke in reply: "I know nothing about eyesight, but if you will breakfast with me to-morrow and explain your invention I will take you on to the Admiralty afterwards." The next morning over eggs and bacon $\mathrm{H}$. H. and his new friend would discuss the subject " hammer and tongs " until $\mathrm{H}$. $\mathrm{H}$. became not less enthusiastic than the inventor.

He was one of the first to be interested in an almost uncanny invention by Sir Hiram Maxim for preventing collisions at sea, and he and Marconi journeyed down to see the instrument tested in its early stages. Watching the meeting between the old Magician, and the young Magician, $\mathrm{H}$. H. congratulated himself on living in the twentieth century, free from the charge of conspiring with sorcerers and dealers in black magic.

Any question of an injustice immediately became his to set right-promotion deferred, or a pension ungranted, became an all-absorbing matter until it was settled in the only right way. The helping hand

1 The only thing we learn from history is that we never do learn anything from history.-HEGEL. 
he extended to young men at the outset of their career brought much happiness into his own life; and one likes to think of the kindness that prompted him to give up a large deck cabin in a crowded ship in the Red Sea because he had heard from the ship's doctor that a poor lady was lying dangerously ill in an airless cabin next to the heat and noise of the engine-room. It was a simple act of common humanity, and yet it had occurred to no one else on board to perform it.

It is not easy to write of the views $\mathrm{H}$. $\mathrm{H}$. held on the deeper things of life. He did not often speak of his ideas regarding religion, but one knew that the simplest form of faith was his. He held an unquestioning belief that God was an all-loving Father from whom the worst of us will obtain a merciful hearing, and in whose presence all misunderstandings will be cleared up and all pettiness and wrong-thinking will fall away as a garment.

"If I were a clergyman I would preach Charity, Charity, Charity, every Sunday of my life until at last people understood the meaning of the word," H. H. was sometimes heard to say. His favourite hymn was " Lead, kindly light," and those glorious words held for him the consolation of the whole world. The epitome of his life's teaching might be expressed in the lines of Kipling:

"Teach us the strength that cannot seek

By deed or thought to hurt the weak,

That under Thee we may possess

Man's strength to comfort man's distress.

Teach us delight in simple things

And mirth that has no bitter springs,

Forgiveness free of evil done

And love to all men 'neath the sun." 


\section{CHAPTER X}

A CHAPTER BY T. P. O'CONNOR

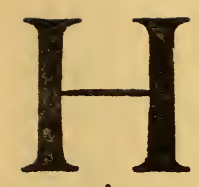

ENNIKER HEATON was a remarkable example of how a man can carve out for himself his little niche in the world of tenacity, and by a genial temper that disarms criticism and wins ubiquitous friendship. He was not a speaker, he was not a writer, and was not even much of a politician, and yet he made a deep mark upon his times, and effected more practical work than nine out of ten of his contemporaries in the House of Commons, and his death will cause far more regrets than that of many a man who occupied a much higher place in political conflict.

Starting life poor, but ambitious like so many other energetic young children of the Old Land, Henniker Heaton sought fortune in Australia. $\mathrm{He}$ did not often speak of his early days, or of his early struggles. Probably they had been so hard that he didn't care to recall them, especially when he basked in the sunshine of the complete prosperity he enjoyed for the greater part of his life. But now and then he would uplift the veil, and you could hear stories, thrilling and amusing, of the shifts to which a penniless young settler had to resort when Australia and he were young. 


\section{Successful Persistence}

It was in the early eighties that Henniker Heaton returned definitely to the Old Country, by this time a rich newspaper proprietor, at ease with fortune, free to do and go as he pleased, and eager with the desire to find distinction in the land from which a few years before he had gone in search of fortune.

Entering the House of Commons as Conservative member for Canterbury, he had not been there more than a few weeks when he began to devote himself to the subject which was to become the master passion and almost sole purpose of his political life. By an extraordinary instinct he could discover in the Post Office service its weak points, and went for them with unfailing aim. It was Henniker Heaton's strong will, tenacity, patience, and indifference to the comfort or the goodwill of successive Postmasters-General, whether of his own or the other Party, which was the driving force that lay behind his agitation and successful propaganda.

\section{Perennial Questions}

His success was obtained, too, by ways and methods which reveal a side of House of Commons' life not realized by the outside public. He spoke but rarely in the House, and then not with striking effect, and yet he got his way. The first weapon was the persistent and the perennial question to the PostmasterGeneral. Almost every day, for almost every week, in every session, Henniker Heaton would put on the notice paper of the House of Commons two, three, half a dozen questions with regard to small or large 
points of administration in the Post Office. There was nothing too big-there was nothing too smallfor this insatiable inquirer. Sometimes it was a suggestion of inter-Colonial policy of great magnitude, but just as often it was a question as to why one city with a double and lengthy name, say like Newcastleon-Tyne, was charged as an address as one word, while some other city, like, say, Barrow-in-Furness, was charged as two words. The Postmaster-General of the period fretted and fumed under his pitiless and insatiate shower of interrogatory-especially in the case of the late Mr Raikes, who, though a courteous, was also an impatient Minister, and especially was inclined to resent these pin-pricks from a man of his own party. But Henniker Heaton was not a man to be cowed, or frozen out, or exhausted, and he went calmly on his way, with something of the stolid steady movement of a genial elephant trampling mercilessly, but without malignity, on all small obstacles.

\section{Ways and Means}

This was one of Henniker Heaton's chief weapons. $\mathrm{He}$ also waged an active war with his pen. When he got on his favourite subject he could almost convince you, as he certainly convinced himself, that postal reform was the one panacea for most human ills. A third and most powerful weapon in his hands was the deputation to Ministers. He could get up a. bigger, a more powerful, and a more representative deputation than any other member of the House of Commons. The peculiarity was, that the deputation was the result far more of his personal influence than of any strong feeling of agreement with his views. 
He belonged to that rare order of men who seemed to find it easy to get other human beings to do anything they are asked.

Finally, the postal reformer was one of the great unseen powers of the House of Commons, because no man in it was so constant, so generous, and so agreeable a host. There was scarcely a day when he did not bring together, either in the House of Commons or in some club, a big lunch or dinner-party. His guests came from everywhere. An inveterate globe-trotter, constantly passing between his home in England and his business in Australia, never satisfied until he met and entertained every man in the world worth knowing, insatiate in his interest in human beings, he could bring together more remarkable men, and from more diverse parts of the world, than almost any other man who ever sat in Parliament. It was a Continental statesman one day, the next it was a Minister from Australia, the next from Canada, and then perhaps a great Governor of some outlying region of the Empire. At his table there was no distinction of party : Liberals, Tories, Irish Orangemen, Irish Nationalists, all were welcome, and all felt equally at home. It was at a feast of this kind that you saw Henniker Heaton at his best. He said little himself, being more anxious about his guests enjoying themselves, and bringing out what was in them. The chief contribution he made was a hearty, infectious laugh, deep-noted and resonant, that became so familiar as to be almost historic in the dining-rooms of the House of Commons. 


\section{Social LIFE}

He was a great clubman. He was not only one of the early founders, but also one of the most prominent figures in the Bath Club. He had strange fads about health, and one of them was a faith in the efficacy of the Turkish bath, and for years he might be found almost every morning, in the hottest room of the Turkish bath in the Bath Club, following this up with a swim in its spacious tank. He also visited the Continent freely. In the winter he might be seen, tall, eager, ingenuous, perspiring at the tables in Monte Carlo, now and then shaking the building with that loud, resounding laugh which was so familiar to his friends. For more than a quarter of a century he went regularly every year to Carlsbad, and to every one of his friends he preached the gospel that the waters of that well-known resort were the end of all human maladies.

Sir Henniker Heaton did not effect in postal reform all he desired ; but one great reform he did accomplish which entitles him to grateful and long-enduring memory. To him more than to any other human being is due the penny postal service between England and America-one, doubtless, of the many causes that have brought the peoples closer together. $\mathrm{He}$ was equally eager-it was his last great campaign-to cheapen the cable service between them, and between all parts of the Empire. He might apparently have remained Member for Canterbury for his life, but there came a split in the party, and his once splendid robustness was shaken, and he resolved to resign. His friends remonstrated, and there was almost a universal groan at the possibility of a figure so familiar 


\section{I36 SIR JOHN HENNIKER HEATON}

and so popular being removed. But he persisted: said he was at peace with all men and quite happy. So one day he was seen standing at the Speaker's chair as the last Parliament was about to dissolve, with wistful eyes, taking his final look at the place of which he had been an essential part for more than twenty-five years. 


\section{CHAPTER XI}

\section{AMONG FRIENDS}

"Practical and steadfast in purpose; trusted in all the relations of life, and who by persistent effort has done more than most men for ensuring the unity of the Empire. I am proud to have the privilege of Sir John Henniker Heaton's friendship." LORD StrathCONA,

High Commissioner for Canada.

T $N$ looking back on the circle of friends that $H$. $H$. gathered around him, it is almost startling to find the number of great Irishmen included in it. Sir Charles Gavan Duffy, Lord Russell of Killowen, Sir John Pope Hennessy, Lord Rosmead, Lord Killanin, John and William Redmond, Robert Martin (Ballyhooley) and T. P. O'Connor, were all among those in whose society and brilliance he delighted.

It is an unfortunate fact for biographers that the greater the friendship, and as a consequence the more frequent the intercourse, the fewer are the letters, other than brief notes exchanged.

Old members of the Carlton may feel that more should have been written of $H$. H.'s connection with the club, where his chief interests centred and where he was so familiar a figure. He knew the traditions and the history that was made and unmade within its walls, and he was never happy for long away from the Carlton.

The friendship existing between $\mathrm{H}$. H. and Lord Blyth was of that enduring quality made firmer by 
time and dearer by recollection of hard-fought battles. They were associated in nearly every movement for cheapening postage and telegraph rates. A very frequent exchange of letters was kept up, and by the courtesy of Lord Blyth I am able to produce one or two. The following was written from the Sackville Hotel, Bexhill-on-Sea :

\section{MY DEAR LORD BLYTH,}

Very pleased I am to get your long and genial letter. I think I told you of my doings since leaving you and my beloved Carlsbad. You may depend upon it there is no more kind or restful place in Europe ; but it is difficult to follow the ideal life, feeding the birds under the trees, taking breakfast there, and attending the beautiful concerts in the Post Hof and other places. You must try to rest more next year, although my little wife says I ought to be the last to preach on this subject of rest. I think I told you of the splendid steamer from Bremen. Marconi and his charming Irish girl-wife met me at the Wharf at Southampton, and perfect happiness followed at Eaglehurst. There were two beautiful Irish-Italian children in care of an ideal nurse from Italy. I would like Claude Rome's fine little boy to play with Marconi's children, and to hear their unsurpassed baby Italian songs.

You are a judge, and you like good letters. Well, I received one from Lord Halsbury the other day, very unique. Liberals may not consider him the greatest living Englishman, but I would like you to mention the name of one with more force of character, more manly, or more sound in judgment, or whose law is made to conform with justice and fairness. Let me quote an amusing passage from Lord Halsbury's letter to me on his birthday: 
Ashton House,

ISLE OF WIGHT.

My dear Henniker Heaton,

Nothing but the warmth of personal friendship could excuse what the paper you sent to me represented you to have said to the gentleman who reported your views. I have been overwhelmed with the kindnesses of my friends and feel myself somewhat in the position of the litigant who did not recognize himself in the description given of him by his Counsel, but when he did he wept to know what a fine fellow he had been and did not know it himself. Sincerely I most heartily thank you, and believe me, I am deeply, etc.

\section{HALSBURY.}

The picture of the criminal weeping in the dock, while his Counsel tells the jury what a noble fellow he is, causes my family much amusement.

Your sincerely attached friend,

J. Henniker Heaton.

From Bath on December I2, IgI2 he wrote:

\section{My DEAR LoRd Blyth,}

The Dinner was very successful and devoted to Imperial affairs, wide-world postage, wire and wireless. I did not realize how important the plumbers are in this planet until I heard Sir Thomas Barlow and Sir Vesey Strong. The new Lord Mayor spoke vigorously and carried his audience by his undoubted honesty and earnestness. The new High Commissioner for New Zealand, Mr Mackenzie, who was Prime Minister there for a long while (as successor to Sir Joseph Ward) also spoke, telling us the story of his introducing compulsory training in that new landthe Great Britain of the Southern Hemisphere. He 
made a capital defence of his action in preparing his people to defend their splendid homes in the new country. I was very glad to get back here to rest, and endeavour to make some progress with the arranging of my correspondence during the 30 years. I am having the letters bound in volumes of fair size. The best letter writer was Dean Lefroy. Sir William Harcourt's letters, in a few of which he lets himself go, are strikingly good. Lord Salisbury's letter denouncing the meddling Methodist and Nonconformist Ministers will create a row. He was guilty of " blazing indiscretions," although it was not his fault when he mistook you for Lord Roberts and told you State secrets. It was a mistake to call a nation "Hottentots." It is a wonder that no one has written the life of Lord Salisbury or given a selection of his letters. I shall never forget his frankness and manly attitude when we discussed Home Rule for Ireland with Sir Charles Gavan Duffy, and I had the first interview with Lord Carnarvon in Dublin. We had another historic interview. The Postmaster-General and his officials were wavering when we were urging the purchase of the Cables between England, France, and Belgium. We won through Lord Salisbury taking a part. It was on a parallel with the interview between Whitelaw Reid, my old friend Lord Blyth of Blythwood, and myself. In 25 letters from Lord Salisbury, including the one when Raikes had a rebellion in the Post Office and Salisbury told me that either Raikes or Stevenson Blackwood would have to go (he meant Raikes). The new trouble that oppresses me, and it is a great one, is the propriety of letting the public see these letters although all the men are dead. I hope I am incapable of doing a wrong to anyone on this earth. Never once have I been disloyal to my party, never once voted against my party. Of course I never was a keen politician, never attacked the Opposition, but worked for Empire. 
Excuse this egotistical letter in my sunset days, I have no vanity, no desire for fame.

Affectionate regards to you all,

Your attached friend,

J. Henniker Heaton.

A letter from Lord Blyth to H. H. in Australia, dated September 25th, I9I3:

MY VERY DEAR H. H.,

After the way I have neglected you as regards writing I am now half ashamed to communicate with you again. I console myself with the thought that a letter could not possibly have reached you before your departure from Australia. . . .

Before Sir George Reid left for Australia and before my departure for Carlsbad, I had the honour of being one of a very distinguished party of $\mathrm{I} 4$ who dined with Sir George at the United Service Club to meet Mr Elihu Root, the well-known United States Senator, where I met Lord Haldane, Lord Morley, and $\mathrm{Mr}$ Bonar Law, next to whom I sat, and we had a most convivial evening. You will no doubt have seen that the Foundation Stone of the Australian Commonwealth Building in the Strand was laid by King George. Nothing could have been better arranged by Sir George for the distinguished company that there assembled. I met Lord Stamfordham at a dinner at the Athenaeum Club a day or two afterwards when he told me that the King was delighted at the splendid way Sir George had managed matters, and really I think he has shown himself quite a hero of this season, and has done more than most men for the salvation of the Empire. I hope we shall soon see him back again here and that I may often meet him with you. . . .

I should tell you that under promise made some time previously I went last week to Holker Hall in Lancashire to stay with Lord Richard Cavendish, 
for the entire dispersal of his celebrated herd of Shorthorn Cattle. You may remember that the late Duke of Devonshire had sales from time to time, when the prices realized were fabulous. At one of the sales Sir Wilfrid Lawson gave 600 guineas for a bull, and two or three days after it was found dead in its stall, whereupon Sir Wilfrid took up a piece of chalk and wrote on the wall :

\section{"Here lies Oxford 6th placid and cool, Bred by a Duke and bought by a fool."}

I am afraid I shall bore you with this long letter, if it ever reaches you, although there are many subjects I should have touched upon if there had been time.

I look forward, however, to many opportunities of having a chat with you when you return.

With my warmest regards to you, Lady Henniker Heaton, your daughter, and indeed all your family.

I am, always,

Your most affectionate friend, BLYTH.

It might truly be said that $H$. H.'s circle of acquaintances stretched from the Tropics to the Arctic Ocean. We find H. M. Stanley writing to H. H. in I897: "It is warm and uncomfortable in London and I pant for fresh air." That Stanley of Africa should find London too warm, is one of those endearing touches that link him with his fellow-men only less agreeably than the fact that even his gift of locality was occasionally at fault.

"Brave Henry Stanley found a track

Through Afric's inmost Dark,

But lost his way (I heard him say)

In our St James's Park."

Mr Reginald Geard, the Honorary Secretary of 
the Savage Club, sends the following notes as to H. H.'s association with that club :

“Sir John Henniker Heaton's Membership dating back to the year I885, he was among the oldest members, and there was none more closely identified with the home life of the Club. He frequently lunched in Adelphi Terrace, particularly on Saturdays, when there was generally a gathering of familiar spirits who exchanged the latest stories from Fleet Street and the City with Sir John's chit-chat from the House of Commons. After lunch he usually stayed on for a game of Bridge - to the end maintaining that straight Bridge was better than all your Auctions. Sir John always said that he went to the Savage Club for rest and recreation and his fellow-members made a rule that postal grievances and the Postmaster-General should never be mentioned in his hearing.

"He would forget that such things existed in the pleasure of hearing Odell give 'Harvest Home' or Willie Nichols sing ' On the Road to Mandalay.' Some brilliant lightning sketches done by 'Tom Brown' he carried away and had framed in his library. The walls of the Club are decorated with a picture of Sir John, Mostyn Pigott, and others playing a round game, called Spelka, which had its genesis in the Club and of which Sir John was an enthusiastic player.

"The Saturday night House dinners of the Savage Club are world famous and year after year Sir John was invited to take the chair. Among the memorable occasions on which he presided, may be recalled the dinner of 2Ist February I903 when the Club entertained his great friend, Signor Marconi, when a special menu was drawn by the well-known sea painter, Charles Dixon.

"Another brilliant menu, preserved in the Club archives, is from the brush of John Hassall, R.I., in 
celebration of the Savage Club Empire Night dinner, June 2oth, I908. It depicts the Chairman, $\mathrm{Mr} \mathrm{J}$. Henniker Heaton, M.P., as he then was, clad in flowing toga and tooling a team of wild horses from a Chariot that had left the earth for the Clouds. The Steeds' collars bespoke them 'United States,' 'Canada,' 'Australia,' and 'Africa,' while the Chariot bore the Legend 'One penny all the way!' A happy recognition of the Chairman's life work for the penny postage.

"It was on 29th June, I9I2, that Sir John was specially invited to be the guest of the Club at a house dinner presided over by Mr Yeend King, V.P.R.I., when he was cordially congratulated in Savage style on the Baronetcy which the King had just conferred upon him.

"When the end came, in September, Igr4, a wreath, 'In Memoriam from his brother Savages,' was laid upon the grave in Geneva by his old friend and fellow Club man, Dr Turtle Pigott, while a deputation from the Committee attended the Memorial Service at St Margaret's in London.'

Apart from his political life, H. H. chiefly enjoyed what may be called his excursions into literary society. The many Sunday afternoons spent by him, and his wife, with Wilfrid and Alice Meynell were among their dearest and happiest recollections. At Palace Court House was gathered all that was choicest in artistic and literary London. It is impossible to describe the effect Mrs Meynell has upon her surroundings-there is only a feeling that the chasm between the material world and the spiritual world has been suddenly bridged.

In reply to my request for a few memories of $\mathrm{H}$. $\mathrm{H}$. Mr Wilfrid Meynell writes : 
<smiles>CC1C#CCC(C)C1C</smiles> 

"A little dinner-party in the Addison Road region of London was my first introduction to John Henniker Heaton, then freshly arrived from Australia. Our host was Dr Rae, a hero of mine in my boyhood when he went on his Arctic Expedition in search of Franklin. He did not find the Explorer, but he found the explorer's spoons, and I remember an old rumour of dispute as to whom these relics really belonged to, Dr Rae or the surviving relative of Sir John-a case in which law and feeling might indeed be sharply sundered. Mrs Rae, in charm and character the youngest woman who wore white hair, and her sister, Miss Skeffington Thompson, were ardent friends of Irish Nationality, and my impression is that the man from the Antipodes rather shared their sympathies.

"Gladstone had not then affixed the Liberal label to Home Rule ; and I remember many Conservatives who were favourable in those days to a cause from which party loyalty later alienated them.

"As to Party ties, though it was part of Heaton's loyalty of character to respect them, I do not think that Party animus found any lodgment in his disposition. He had his friends among men of all opinions; and, associating ideas of practical service with political life, after the manner of most Colonials, he did not come to England wearing any party badge ; and it was accident rather than design that gave him his opportunity for National usefulness as Conservative Member for Canterbury.

"My first meeting with him in that environment led to a friendship broken only by Sir John Henniker Heaton's death. In the busy life of London, dinersout meet and like one another, and say they hope to meet again, and then lapse into a nothingness that is just kept in evidence by a casual nod across a clubroom, or in the street.

"But there was something genial about Heaton that put you at once on terms almost of intimacy. 
For a man of independent opinions, very definite ideas, rather strong personal prepossessions, and even prejudices, he was amazingly amenable, and thus while it was particularly pleasant to agree with him one could disagree without a hint of disagreeableness. Perhaps it was because he was very human. I use the word with no patronizing concession of weakness in it. Mother wit was his, of a masculinity denying its name: and of a brand that had an agreeable novelty because it was Colonial. I know a sensitive speaker who says she found it easy to speak to an American audience because it is in the air that they actively want to like you, whereas in England you feel that your hearers are at the best passive. In the case of Heaton you felt he wanted to like you, and wanted you to like him, a very simple process in consequence it seemed. His outlook and yours might be totally at variance in literature, and therefore 'in life Temporal and Eternal,' and yet you felt for him from the first a friendship which soon became an affection.

"In a rather long life I never met anybody quite so hospitable. A request to give any recollections of him as Host and Guest brings home to me how often he served in the first capacity, how rarely in the latter. He seemed never to be really happy unless he was entertaining. ${ }^{1}$ This was an instinct with him-he must be the giver-more blest than the receiver. You cannot succeed in this capacity at random. It takes you all your born days to be anything worth having: and without the sincere effluence of consistent habits love itself degenerates into politeness,

My deAR Baronet,

1 a Granville Place.

So our meeting must be in London and you are to fix the day and the hour. The restaurant and the Host! Be entertained for once-you who are always entertaining in two senses.

Your attached friend,

Wilfrid Meynell. 
politeness into sham. A little slip of printed matter, carried in his pocket till it became threadbare, is before me now: 'I shall pass through this world but once; any good thing that I can do or any kindness that I can show to any human being let me do it now. Let me not defer it or neglect it, for I shall not pass this way again.'

"Those who knew him will recognize in these words his abiding rule in life.

"This genius for hospitality was not based merely on considerateness for those with smaller means than his own. I have seen men of 'Great possessions' submit as readily as myself to the fascination of this form of his friendliness. Below 'The Champagne Standard' of hospitality he was distressed when far afield to fall, and the sparkle in his eye when success crowned his efforts was more inviting than the sparkle in the wine. His little courtesies like his larger kindnesses were done with the tact that voided the hard rule of an advantage to one being a disadvantage to another. The little boy-scout who felt worried after going to bed because he had done no kindness that day, and who therefore got up and gave the canary to the cat, has many a double among the mature, but Heaton was not of their number. Royalty would not have needed to send him the list of the guests to be invited to meet it-his own instinct would have sufficed. Among the many memories of meetings he brought about I recall particularly a breakfast at the Bath Club with the Hon. John Wanamaker as a fellow-guest. A Postmaster-General himself in one of the administrations of the United States, he talked indeed of posts, then of poets (he loved his Riley) and then of pictures. It was a May morning, the Academy was close at hand, whither we three adjourned to compare impressions, to cavil and in one case at least, to be conquered. For Sargent was in his glory that season, and Sargent belonged to both 
our countries, and I had to name a new land common to us-the Sargentine Republic.

"Teas on the Terrace and dinners at the House remain as affectionate memories of those otherwise rather frigid and formal precincts. In his own home those amenities had their full flowering; but of this it must be the happiness of others to speak.

"A busy man, he had, of course, time for everything he wanted to do-generally a kindness to some one. No one of my acquaintance would take more trouble than he to serve a friend, or a friend's friend, and it must have been a. constant joy to him that the great cause with which his name is associated was one by which the sum total of the World's store of kindness is likely to be increased. To be genial and to be genuine-by his double perogative he lives in my memory as a man of men."

To this appreciative friend, $\mathbb{H}$. $H$. wrote many letters. The one here given makes light allusion to a paragraph of banter (presumably Mr Meynell's in "The Daily Chronicle" about H. H.'s friend, Thomas Sidney Cooper, R.A., whose name and letters were worked into an anagram:

\section{Thomas Sidney Cooper, R.A. \\ I CAN DO TOY SHEEP OR RAMS.}

[Mr Meynell admits himself the quoter but not the author of the anagram.]

My deAR MeYNell,

$$
\text { House OF CoMmons, }
$$
I4th August IgIo.

I am delighted to hear that you are in London. When I am tired and want a refreshing chat I walk over to the Pall Mall Club hoping to meet you, but I am not often successful.

What colossal coolness! I could not sleep after 
reading "The Daily Chronicle's" treatment of Thomas Sidney Cooper. The boys throwing stones at the poor frog was as nothing to it. It may be fun to you readers, but it was death to the hopes of Sidney Cooper's friends.

After a decent interval had elapsed (to make the public forget your cruelty) we happily received from the King a note, I shall show you if you will lunch with me on Saturday at I p.m. here.

And we can talk of other interesting events.

Yours always,

J. Henniker Heaton.

An interesting letter from Dr John Rae, giving an account of his search for Sir John Franklin, was written to $\mathrm{H}$. $\mathrm{H}$. in $\mathrm{I} 882$ :

\section{Dear Mr Heaton,}

I would not venture to trouble you about the now old story of poor Franklin's fate, had you not referred to it in your note to my wife, accompanied by the beautiful and interesting book you have sent her. Before I returned from the Arctic in I854 I had the most clear assurance from the Eskimos that a large number of white men, at least about 45, had perished about four winters before, at a place on the Mainland of America, which was a long day's journey with dogs and sledge from the mouth of a large river where there were plenty of salmon, and that the position was the side of river towards the setting sun or the West. That the party when seen alive were looking very thin, and made very short days journeys, hauling one or two boats. That they were first seen travelling southward, near the west shore of a large island (Keicktak). The river and island were evidently the Great Fish River of Back, and King William Land, formerly thought to be a part of Boothia, but which I proved to be insular in 1854 . 
There were I6 Officers of both ships, I obtained and brought home with me articles, with crests, initials or other marks, showing that they had belonged to I4 of those I6 Officers. There were among these Sir J. Franklin's Cross of Knighthood (which a woman wore round her neck as an ornament) and a number of his spoons and forks.

On the very day of my arrival I went to the Admiralty and saw the First Lord, Sir J. Graham, who on hearing my story said, "Are you aware, Dr Rae, that the Government have offered a reward of fIo,000 for news of the fate of the missing Expedition?" I replied no. He then told me of it, and said that he thought we were entitled to it and would be standing in my own light if I didn't apply for it ! My Expedition was not a Government but a Hudson's Bay Co's. one, fitted out wholly at their expense, therefore my report was sent to the Company for and forwarded by them to the Admiralty.

An immediate answer, dated 24th October I834, was addressed to the Secretary of the Hudson's Bay Co., in which are the following words, "Their Lordships request you will inform Dr Rae of their Lordships high approval of the services of Dr Rae who has set at rest the unfortunate fate of Sir John Franklin and his party."

The award of $f$ Io,0oo would have been granted almost immediately, but Collinson was still in the Arctic Seas and it was very reasonably thought that he might possibly have a prior claim. This doubt arose from the fact that the Admiralty had rather prematurely paid a somewhat similar claim for finding some lost Missionary people a short time before, another claim soon after having been made.

An Expedition, meantime, was sent down to the Back River to inquire further into the matter, and look for the documents. Nothing of importance came of it, as I believed and stated from the first 
that all documents had been destroyed. I mean journals and books, because the natives told me, that at least a dozen books with markings on them, (not blank books) had been seen, and being of no use to the Eskimos were thrown aside or given to the children to play with and torn up.

No documents have ever been found except that by $\mathrm{M}^{\prime}$ Clintock in Spring I859, which informs us that the good Franklin died in I847. All M'Clintock's other information confirmed mine in a wonderful manner.

After Collinson's return with no news the reward ( $(10,000)$ was paid to me and fellows in spite of some strong opposition from one or two quarters.

Excuse my troubling you with such a very long letter on a very small and old subject.

And believe me,

Sincerely yours,

JOHN RAE.

Early in life, through the good offices of Sir Charles Gavan Duffy, H. H. was given an introduction to Carlyle and spent an unforgettable hour in the Chelsea house. Carlyle spoke much of Australia and asked repeatedly about the youth of Australia: what were the young men doing-what were they reading? Did they work? H. H. could quote an Australian friend, who had heard from Carlyle's own lips, "Life only begins with self-renunciation." When $H$. $H$. rose to leave, Carlyle shook his hand with an approving, "I am told you are a young man who is going to do some great work."

"Henniker Heaton, what a name for a novel," cried Anthony Hope, meeting $\mathrm{H}$. $\mathrm{H}$. for the first time.

Unfortunately, Rudyard Kipling's promise of some verses was never fulfilled. On December I7th, I900, he wrote from The Elms, Rottingdean: 
Dear Mr Henniker Heaton,

I've been watching your fight with an interested eye from far off, and have seen you getting your own way, inch by inch and foot by foot, with the notion that some day I'd do a set of verses about it. But it's more difficult (verses I mean) to do them than you think. Give me time and perhaps I shall be able to make something worthy of the new step. I can't do things in a short time.

Sincerely and with congratulations, RUDYARD KIPLING.

For many years $\mathrm{H}$. $\mathrm{H}$. saw a great deal of W. T. Stead, and sorrowed deeply over his tragic death in the ill-fated "Titanic." Memory recalls a summer day in June when W. T. Stead, David Murray, R.A., Archdeacon Sinclair, and $H$. $H$. travelled down to Windsor together as fellow-guests of their mutual friend Henry Arthur Jones, the dramatist. W. T. Stead had the appearance of the Old Buccaneer: broad-brimmed hat, white hair and beard, and blue eyes of an unquenchable fire and vigour alternating with the sudden dreamy look of one who saw visions. He was in high spirits and his great laugh as he threw back his head was the whole-hearted laugh of a true Englishman.

H. H.'s friendship with Marconi was spread over many years, and each fresh triumph of wireless was watched with enthusiastic and affectionate wonder. The greatest magician of the age, for whom no honour can be sufficiently high, no reward adequate, counted H. H. among his earliest friends. His favourite advice to all young men was to secure happiness in life by marrying an Irish girl, and it was with especial pleasure that he heard of Marconi's approaching 
marriage with the Hon. Beatrice O'Brien, a daughter of Lord Inchiquin.

MY DEAR Mr HeNnikeR Heaton,

$$
\begin{aligned}
& 90 \text { Piccadiliy, W., } \\
& 28 \text { th Jan. I905. }
\end{aligned}
$$

Your kind letter of congratulation has given me and my fiancée the very greatest pleasure.

To have true friends is one of the greatest joys of life, and it is now many years that you have been a true friend to me.

I am so glad you approve of my engagement and hope you will soon meet my future wife.

If I could write as well as you do I would find more and better words with which to express my thanks to you and to Mrs Henniker Heaton for your very kind letter and wishes.

Believe me always,

$$
\begin{aligned}
& \text { Your friend, } \\
& \text { G. MARCONI. }
\end{aligned}
$$

My dear Mr Henniker Heaton,

34 Charles Street, BERKElEy SouARE, W., 2Ist Jan. Igo6.

I am so sorry I was away when you arrived from Australia and missed having the pleasure of sending you a wireless welcome. I followed the contest at Canterbury, and held my breath, so to speak, until the result was known. Now that you are in, and safe, I write you my sincere congratulations.

I do hope I shall have the pleasure of meeting you and yours soon again. My wife asks me to send you her love.

What an awful time the U's have had, especially the members of the late Government!

Yours ever,

G. Marconi. 
Dean Lefroy of Norwich- " the best letter writer" -was a friend to whom H. H. was deeply attached.

\section{My DEAR SiR HeNNIKER,}

Just one line not to congratulate you-this I'll not do, but to gratify my insignificant self by addressing you by a higher title. You are the one member of the Party to whom every living citizen in the mother country, and millions of subjects over sea, is not only indebted-but indebted with every sunrise and with every sunset, and the debt is cumulative, permanent, and universal. I know you don't care for such recognition, and I know that you have the regard and affection of innumerable beneficiaries of your Imperial policy, in all zones and in all civilizations. Ever your attached friend,

D. LEFROY.

Among H. H.'s letters, one of the most characteristic is a note from the greatest of all Empire builders, the Right Honourable Cecil Rhodes, written from the Burlington Hotel, W. :

Thanks for welcome and use of Club.

I see you have got your Penny Postage through. I must get my Railway through, and then we must meet and celebrate joint work.

\section{Yours,}

C. J. RHODES.

The most regular of $\mathrm{H}$. H.'s oversea correspondents was his great friend Sir Joseph Ward, Prime Minister of New Zealand. The following letter was written on the 7 th of May, Igog:

\section{My deAR Heaton,}

Thank you so much for sending the posters to me regarding our offer of support to the British Navy.

It is very gratifying to find that in the dear old 


\section{AMONG FRIENDS}

land it is appreciated, and I am glad to tell you that throughout N.Z. the Government's action has been generally approved. I read with great interest all you say in your letter of 26th March accompanying the posters.

I feel very happy at what we have done, as I feel very strongly that duty to King and Country calls for co-operation between the mother land and the oversea dominions and so show the world that we are deadly in earnest in our determination to stand together as one in reality, and I am sure myself that there is in the matter of Naval Defence a new era opening out for the British Empire.

The Conference that your Prime Minister has announced is a most desirable move. The date it is to be held will determine whether we can be represented. We will be there if at all possible. I am writing hurriedly to catch the mail, with all good wishes.

Yours sincerely,

J. WARD.

In reprinting a letter from the great Victorian hero, Field-Marshal Viscount Wolseley, it is perhaps hardly necessary to speak of the high esteem and admiration he felt for every branch of the Service of which he was Commander-in-Chief. Those familiar with his famous book, "The Story of a Soldier's Life," can never tire of reading the gallant and heroic deeds told with the simple admiration of one fearless soldier for another. To-day, when war is more than ever a science, it is easy to understand the emphasis Lord Wolseley, throughout his career, laid upon the necessity of officers obtaining a scientific education, without which the highest personal valour is insufficient to ensure victory. On November Ist, I900, he wrote from Beech Hill, Sheffield : 
Dear Mr Henniker Heaton,

You asked me before I left this evening, how I thought the officers of our Artillery compared with those in other corps of the Army. I should not like to draw any comparisons, but without being in any way invidious I can point to the fact that our R.A. officers receive a better military education at Woolwich than is usually obtained by officers educated elsewhere. I have always found them most anxious to learn the higher subjects which constitute a sound military education.

Amongst the ablest officers I have had on my Staff, Generals Sir Henry Brackenbury and Sir Frederick Maurice are Gunners, and I selected them because I deemed them the best men for the work.

Believe me to be,

Very truly yours,

WOLSELEY.

From war to peace is the natural transition and therefore the next in order must be a letter from Andrew Carnegie.

Mr Carnegie more than all others was at one with $\mathrm{H}$. $\mathrm{H}$. in his conviction that an easier communication between nations could only lead to a closer union of mankind all the world over; and on September 2oth, Igog, he wrote, from Skibo Castle, Dornoch, Sutherland :

My deAR Mr Heaton,

I should be very proud indeed to co-operate with you in the great cause of Peace, but unfortunately it is impossible for me to be in London next week.

You do well to cultivate the journalists, for really these people have more influence for good or bad, and especially for peace or war, than any other class.

I agree with you that knowledge of other countries 
leads one to the truth, viz., that no nation desires war, and that all that is needed is that the few governing, of each country, should confer freely. I think that a few of the best men of each country, meeting in conference, would agree that the time has come when some of the leading nations should unite in intimating to the world that they expect civilized nations to settle their differences peaceably. They have only to say the word and the power is theirs to banish war.

Delighted to know you are taking up the subject of Cable Communications, for you have a way of getting things done which is rare. I never address an envelope to New York without receiving pleasure from putting my hands upon an embossed Penny Stamp, which takes the letter to London or New York

Always very truly yours, ANDREW CARNEgIE. 


\section{CHAPTER XII}

SOME AUSTRALIAN MEMORIES

$7 \mathrm{HE}$ grandeur and splendour of Australian scenery, the smell of the gum-trees and the blue smoke wreathing upwards, the deep gullies and far horizons held for $\mathrm{H}$. $\mathrm{H}$. a romance and poetry that nothing else could ever rival. He loved the days of blue and gold sunshine, and above all the divine youth of the country and her people. "Ce sont les jours de notre jeunesse qui font le beau temps."

Australia proved a kind stepmother to $\mathrm{H}$. $\mathrm{H}$. as she has been to thousands upon thousands of young Englishmen. That much abused relationship should gain a newer meaning through the large-hearted generosity of Australia's welcome to all her stepsons.

Much of the romance of Australian life has died out with the coming of the railways and motor-cars.

When $\mathrm{H}$. H. first arrived in Australia, bush-ranging was in full swing, and, although he had no experience of being "stuck up," he could well remember the excitement caused by the exploits of Captain Thunderbolt that were then on every one's lips.

There was a story current of an encounter between the notorious Captain Thunderbolt-whose real name was Frederick Ward-and a German band in Goonoo Goonoo gap. The German band pleaded so piteously for their money that Thunderbolt promised that if he should succeed in robbing the principal winner 
at the Tenterfield races, for whom he was on the look-out, he would return it. This promise he faithfully kept, much to their astonishment, by sending to them, to the post office at Warwick, the $£ 20$ he had taken from them.

After such chivalrous conduct, it is pleasing to learn that Captain Thunderbolt met a more picturesque death than the majority of his confrères. This latterday Beau Brocade was killed in a desperate duel with a brave young constable-Alexander Walker-in I870.

Not less romantic were the stories of strangelywon fortunes that were then common talk, as, for instance, the richest copper mines in Australia being sold for a bottle of rum.

The six years H. H. spent in compiling his " Australian Dictionary of Dates and Men of the Time " brought him into contact with many of the oldest inhabitants, and as a consequence his mind became stored with curious facts and legends.

His retentive memory enabled him to enliven his Australian reminiscences with the most curious collection of tales culled from all sources. He records somewhere in his book a remarkable series of wrecks suffered by the same people. The adventures of Jonah pale into insignificance before this plain statement of misfortune :

" The 'Mermaid,' colonial government cutter, left Sydney for Raffles Bay, but on entering Torres Straits she ran on shore and was lost, October, I829. All on board were saved upon a rock. In three days the 'Swiftsure,' Captain Johnson, which sailed from Tasmania, hove in sight, and took on board the captain and crew of the 'Mermaid,' but in a few days she also ran on shore and was wrecked. Two days afterwards 
the 'Governor Ready,' also from Tasmania, April 2, passing within sight, took the shipwrecked people belonging to the 'Mermaid' and 'Swiftsure' on board; but was herself wrecked on May I8, but all the people were saved by taking refuge in the longboats. The ship 'Comet,' also from Tasmania, soon afterwards took the whole of the collected crews of the lost ships, 'Mermaid,' 'Swiftsure,' and ' Governor Ready' on board, but was herself wrecked; all hands were, however, saved. At last the 'Jupiter,' from Tasmania, came in sight and, taking all on board, steered for Port Raffles, at the entrance to which harbour she ran on shore, and received so much damage that it may be said she was also wrecked."

Alas, that tragedy after a certain point should become merely ludicrous!

Although $\mathrm{H}$. $\mathrm{H}$. did not arrive in Australia until I864, he was not too late to see something of the goldfever that possessed men's minds, and he heard many tales of the first rush to the goldfields. As every one knows, gold was discovered in Australia in I85I by Edward Hargreaves, a resident of New South Wales. In a few days Sydney was in a ferment. Stockmen and shepherds left their charges, workmen their employment, shopkeepers their stores, doctors their patients, and lawyers their clients, and poured along the roads into the hills.

"One was a peer of ancient blood,

The lord of acres none.

One was a wrangler from the Cam,

In purse and name undone.

One could speak in the choicest Greek,

And one was a bishop's son ;

And they dug

And they dug

For gold." 
Frequently, a nugget of gold that a man could scarcely stagger under was found. It was a common thing to serve out buckets of champagne, and to make pipe lights of $£ 5$ notes. In I856 Mr Cameron, a storekeeper at the woolshed, New El Dorado, rode into Beechworth, Victoria, on a horse called Castor, the animal being shod with golden shoes. The weight of each shoe was $7 \mathrm{oz} .4 \mathrm{dwt}$.

Many were the hopes raised and sunk in goldfield speculations. A favourite story of H. H.'s concerned a large nugget that was sent to England and a company floated which was called by some fantastic name. After a long delay the shareholders, hearing nothing further from Australia, cabled out, "When are you going to begin crushing the gold?" "Directly you send us back our nugget," was the prompt reply.

Among H. H.'s papers was found an old Share certificate of the famous "Big Diamond Syndicate." The stone was found near, I believe, Wagga Wagga, N.S.W., and was at first thought to be a wonderful diamond of surpassing size. A small syndicate was formed to have it tested and bitter was the disappointment when it turned out to be of no value.

Big Diamond Certificate.

No. 47.

THIs is to certify that W. R. Hall is entitled to one I/rooths interest in the Supposed Big Diamond Subject to the arrangements made with $\mathrm{Mr}$ Townshend by Mr J. S. Butters.

Jas. S. Butters.

There was nothing $\mathrm{H}$. H. enjoyed more in later L 
years than meeting old friends and recalling adventures of Australian days. The passage of time could not obliterate from his memory the long hot days spent in the saddle and the nights sitting round the camp fire exchanging yarns and singing the favourite camp chorus, "Rise up, William Riley."

It was a free, happy life, full of hard work and adventure with such amenities as the occasional "Grand Ball" the nearest township would provide. $H$. H. could recall one such gathering, to which he rode a two days' journey in order to be present. The squatters and their wives drove in from miles around, and all went well until the middle of the evening when a tragedy occurred. One of the guests suddenly fell dead in the ball-room. The evening broke up in shocked silence and horror.

On the following day, which happened to be Sunday, service was held at the largest station by a clergyman who was making his annual visit through the district. An unusually large congregation was present owing to the painful impression created on every one's mind by the shocking occurrence of the night before. Taking as his text "In the midst of life we are in death," the clergyman preached a striking sermon, which moved the greater part of his audience to tears.

The next morning, having heard that $\mathrm{H}$. $\mathbf{H}$. was travelling in his direction, the clergyman proposed that they should bear each other company. For three weeks they rode together from station to station, and to his alarm $\mathrm{H}$. H. found he was compelled to listen to the same sermon on each occasion. Naturally his sense of pathos had by this time given way to sheer impatience, and he told the clergyman frankly that 
he must either compose a new sermon or they must part company.

Loath to discard the most affecting sermon he had ever preached, the clergyman suggested that $\mathrm{H}$. $\mathrm{H}$. should travel on a day ahead of him. This arrangement was made in all good faith, and $H$. H. set off alone; but arriving at the next station, he could not resist the temptation to tell his story, and as he had an excellent memory he was able to repeat the sermon word for word, showing the exact points at which handkerchiefs were produced and where sobs invariably broke out.

This story $\mathrm{H}$. H. proceeded to repeat at each stage of his journey, until a frantic telegram reached him from his ill-treated friend: "Come back at once, or cease ruining my meetings." The end of the story was that $\mathrm{H}$. H., after listening to the most vehement reproaches, agreed to travel a day's journey behind the clergyman who was thus able to preach his famous sermon from one end of the district to the other.

$\mathrm{H}$. H. had also many amusing experiences to relate of his early days as a Jackeroo-the Australian term for "tender-foot," or young men new to station-life. Young Englishmen fresh out from home have much to learn, and meet with much abuse in the learning. There is a convention that "in London you may do anything you like except cheat at cards." Young Englishmen are quick to learn that "in Australia you may do anything you like except leave a gate open." If we are to believe local tradition, many an Englishman's bones lie bleaching in the sun because they omitted to conform to this simple rule.

Having then learnt the law of the Gate, and ac- 
quired some dexterity in " boiling a billy " and making damper-a mixture of flour and water baked in the ashes of a camp-fire- $\mathrm{H}$. H. felt himself in a position to entertain his friends on a somewhat more lavish scale. He was at the time camping out with four friends, and they resolved to commemorate Christmas Day by giving a dinner-party.

The pièce de résistance was a chicken which they managed to procure at untold trouble from a great distance. For weeks and weeks the chicken was fed, and watched with the care usually devoted only to prize birds at annual fairs. Far and wide, $H$. $H$. and his friends let it be known that their dinnerparty was to include this exquisite morsel.

The day arrived, and H. H. elected to kill and cook the bird himself. When the moment arrived, he proudly carried in the billy containing the chicken and lifted the cover. The next moment one of his friends had seized the bird and with a volley of oaths flung it at the head of $\mathrm{H} . \mathrm{H}$. The whole party rushed into the open air and fell on $\mathrm{H}$. $\mathrm{H}$. in a body. Poor H. H. ! he had flung the bird straight into the pot after having plucked it, under the impression that no other preparations were necessary before cooking a chicken! That day they had cold mutton for their Christmas dinner. Every housewife, from the Barcoo to Sydney, smiled when she heard the story.

Years afterwards, when $\mathrm{H}$. $\mathrm{H}$. was a constant and popular host in the House of Commons, he would remember the fiasco of his first essay in entertaining his friends.

In early days $H$. $H$. came into contact with the pleasant happy life led by the squatters, whose princely hospitality was already a byword. He never forgot the 
kindness he received nor the encouragement and help he met with from the owners of those vast territories. Some of the old families have died out or gone Home, but many still survive to maintain the traditions of the old Australian days.

Among his oldest friends, he counted the Landales, the Romes, and the MacArthurs of Camden Park, whose family history may be said to be the history of New South Wales. John MacArthur, the "Father of New South Wales," was the first to introduce woolgrowing into Australia, the sheep being supplied from the flocks of His Majesty's great-great-grandfather, King George III, or "Farmer George" as his subjects affectionately called him.

H. H. in partnership with a friend took up a sheeprun " just the size of Kent," but did not succeed in making a fortune in this venture. Later, when the great rush for the tin mines was at its height, he put his capital into some smelting works and once again Fortune turned her back on him.

Nothing could daunt $\mathrm{H}$. H., nothing could shake his conviction that somehow, somewhere, sooner or later he was bound to make his mark. Health was his, and while health remained he would work with might and main, urged on by a determination that repeated failures were powerless to move.

"If you can make one heap of all your winnings And risk it on one turn of pitch and toss And lose and start again at your beginnings And never breathe a word about your loss. If you can force your heart and mind and sinew To serve your turn long after they are gone, And so hold on while there is nothing in you Except the Will which says to them Hold on." 
Realizing at length that his talents did not lie in pastoral pursuits, H. H. left the bush for a journalistic career at Parramatta. As reporter, sub-editor, and editor, he gained considerable experience in various branches of his profession, and there is no doubt that had he confined his activities to journalism he would still have succeeded in making a name. His tastes and character led him to seek a permanent home among the haunts of men rather than in the solitudes of the bush. A certain gregariousness, a restlessness, a love of emulation made him better suited for town life. Never did he regret, nor could he forget his experiences in the bush, but from thenceforth citizenlife was to be his choice. From Parramatta he migrated to Sydney where, as it has before been mentioned, he was fortunate enough to be associated with Mr Samuel Bennett, and as a result came into contact with the leading men of the Colonies. Among his early literary friends were Brunton Stephens, poet and wit, and Rolf Boldrewood, famous as the author of " Robbery under Arms."

It is sometimes interesting to trace the influences that mould the mind and character of a young man. The " Grand Old Man " of Australia, Sir Henry Parkes, was one of those to whose teaching $\mathrm{H}$. H. owed much of his imperialism and his broad outlook. When $\mathrm{H}$. H. went to England a correspondence was kept up from which the following letter, written from Sydney, in 1889, has been chosen :

My dear Mr Heaton,

I should be very ungrateful if I did not thank you very warmly for the trouble you took to bring the Western Australia proceedings before Mr Buckle. 
It was a thing well done on your part for the good of Australia.

Your account of matters and the relation of men in the House of Commons is full of interest to one who has had such limited means of seeing the inner life of the great body to which you belong. I am, as you know, a sincere admirer of $\mathrm{Mr}$ Gladstone: it takes much to lead me to change in my hero-worship when my faith is once formed. But I can admire strength and devotion to duty, wherever I find those noble qualities in public men. Mr Balfour is certainly making a name for himself throughout the Empire.

Just now you will be noticing our new movement for the union of the Colonies. In this country we have all the best minds on our side, and I think the cause is thoroughly popular.

I send you under separate cover a batch of papers on the subject.

Yours sincerely,

Henry Parkes.

Apart from his imperial policy Sir Henry Parkes is famous as the originator of that felicitous phrase " the crimson thread of kinship." It is curious to remember that Sir Henry was the chief opponent of the now forgotten Bill to create a Colonial Hereditary Peerage which was brought forward by the Legislative Council of I853, and met with almost universal condemnation.

Perhaps the man who above all others guided the political aspirations of $\mathrm{H}$. H. was Sir Charles Gavan Duffy, the famous Irishman. His extraordinary personality, his picturesque speech, and his wide reading had a powerful attraction for H. H.'s enthusiastic nature. Sir Charles had had a wonderful career. Born in Ireland in I8I6, he, in 1842 , started 
the newspaper the "Nation." With O'Connell and five others he was tried for treason and sentenced to a fine of $£ 50$ and nine months' imprisonment. After three months in prison the sentence was annulled by appeal to the House of Lords. He later represented New Ross in the House of Commons, but resigning his seat in I855 he settled in Australia. At the banquet given in his honour at Melbourne, he made use of his oft-quoted phrase: "I am an Irish rebel to the backbone and spinal marrow." His friends in Victoria presented him with a freehold estate in order to qualify him for a seat in the Legislative Council, and what was even more remarkable the diggers of Ballarat pledged themselves to give him an ounce of gold each.

Many anecdotes were told of his various elections, but the one he preferred was his meeting with a constituent after he had been elected by a majority of one. Grasping his hand Sir Charles said: seat."

"Then yours was the vote that gained me the

"Bedad, it was two of thim," replied his enthusiastic compatriot.

From Sir Charles, H. H. learnt much of his sympathy with and admiration for Ireland, and throughout many years Sir Charles was a valued counsellor.

After making his home in England H. H. returned to Sydney every few years, but latterly his visits were inevitably saddened by the gaps made by death among his old comrades. With the loss of Sir James Graham, Sydney could never be the same for him, though the kindness and hospitality of Sir Thomas and Lady Hughes and others made his last visit as 
enjoyable as the companionship of well-loved friends could make it. It was a very great pleasure-though " it makes me feel very old," he said-to meet again, as Governor of New South Wales, Sir Gerald Strickland, whose friendship stretched back to the days when His Excellency was an undergraduate at Cambridge.

Throughout his life $\mathrm{H}$. H. preserved a feeling of gratitude to Australia, which found a reflection in the warm welcome he gave to all Australians visiting England.

He had a passionate belief in the future of Australia and the vigorous manhood that was inherent in her sons. At this hour, when the heroic deeds of the Australian contingent at the Dardanelles are thrilling every English heart, it is interesting to quote a passage from a speech $\mathrm{H}$. H. made at Canterbury over twenty years ago:

"There is no cause to apprehend that England will ever be sullied by the foot of an invader, but one of our earliest Australian poets has indicated Australia as the refuge of Britannia, with her shattered trident, in such a case.

"And, oh Britannia! should'st thou cease to ride Despotic Empress of old Ocean's tide ;

Should thy tam'd Lion-spent his former might-

No longer roar, the terror of the fight :

Should e'er arrive that dark, disastrous hour,

When bow'd by luxury, thou yield'st to power ;

When thou, no longer freest of the free,

To some proud victor bend'st the vanquished knee,

May all thy glories in another sphere

Relume, and shine more brightly still than here;

May this-thy last-born infant-then arise

To glad thy heart, and greet thy parent eyes ;

And Australasia float, with flag unfurl'd,

A new Britannia in another world!" 
The poem is by William Charles Wentworth, and was written in 1824 when the memory was still vivid of the threatened Napoleonic invasion.

Who is to be the poet of Australia's devotion and sacrifice to the Empire to-day? 


\section{CHAPTER XIII}

\section{AS A POSTAL REFORMER}

"In countless myriads to and fro

These fateful missives come and go,

Weaving like shuttles as they fly

The web of human destiny.

Letters of business, gossip, love :

An undistinguishable drove,

Until you break the seal-and then

They make or mar the lives of men."

LORD DUFFERIN.

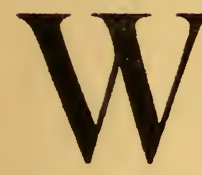

$\mathrm{E}$ have it on the authority of $\mathrm{Mr} \mathrm{E}$. V. Lucas that the first letter known to history is that sent by King David, conveying his request that Uriah the Hittite might be set in the forefront of the battle. It is a far cry from Judea to Mount Pleasant, and it would need a more ingenious pen than mine to trace the evolution of the modern post office from its Hebraic origin. However, I give an interesting extract from "Stuart Life and Manners" by P. F. W. Ryan : ${ }^{1}$

"In England the first post office was established in 1635. It was the official recognition of a system which had been growing up for generations, a system in which the common carrier was the first, the most primitive link, a system in which he was long to continue an indispensable auxiliary. A horse-post and foot-post were now, however, organized with the object of providing regular and speedy means of communication between all quarters of the kingdom.

1 Reprinted by courtesy of the Publishers, Messrs Methuen. 
"The horse-post rode from stage to stage, changing his steed at the appointed resting-places. As he galloped along over the ill-cultivated and sparselypopulated country-side, he from time to time waked the echoes of the lonely wastes with a brave flourish on his horn, warning the inhabitants of his coming. Eagerly, far and wide, did they strain their ears to catch that welcome blast, and, having heard it, from grange and farmstead and hovel, moved by common emotions, gentle and simple streamed to cross-roads and wayside hostelry, hopeful that the courier would not send them away with empty hands. When communication was beset with so many difficulties and dangers, months and even years sometimes elapsed without tidings coming from the wanderer to those he had left behind. Fond hopes that over and over again had been disappointed revived as the postman's horn rang over hill and dale, penetrating to the great heart of the castle hall and to the cheerless hovel, where sire or dame, or wife or sweetheart, cherished the image of some dear one battling for fame at the palisades, or for wealth on distant seas.

"The despatch of letters to-day is an automatic affair. The machine is human, but it is a machine none the less. But in the seventeenth century every step exacted intelligence and resource. The postal system depended, too, for its success upon the honesty and goodwill and energy of an immense number of people who were independent, almost entirely, of anything in the nature of supervision. If one desired to send a letter to some remote town in Yorkshire, one went to Ludgate, then to the Bell Savage Inn close by, and there entrusted it to the carrier for the county in question. Or going to St John Street and there entering the Rose and Crown, one found regular post for that shire. The messenger from London would not penetrate into by-ways. Each county had its system of foot-posts, which linked the outlying dis- 
tricts with its chief towns and with the great high roads. The London courier, pressing on to his terminus, was relieved of packets for remote regions by the local postman, who in turn passed them from hand to hand to their destination. In somewhat similar fashion, though less regularly and smoothly, letters intended for Wales or Scotland or Ireland were carried over the long and tedious journey to the hands for which they were laboriously indited. Worcester and Chester were centres whence the Welsh post started, while Berwick was the natural centre of distribution for North Britain.

"The horse-post was a comparatively swift service, and where packets of value were in question, more to be depended on than the carrier or foot-post, if the highwaymen did not cut short the journey."

In I840 Rowland Hill established Inland Penny Postage, the first great step that was to make the British Post Office the finest in the world. At this distance of time it is hard to realize what such an innovation meant to the poorer classes, nor how much it did to sweeten and brighten their lives. Sir Rowland's scheme was opposed by critics prophesying a loss of revenue, but he lived to see their arguments refuted.

Without detracting from the valuable work of Elihu Burritt, it may be mentioned that he himself explained that when he advocated Ocean Penny Postage he meant in reality threepenny postage: one penny for England, one penny for the ship, and one penny for the land of destination.

The cause that led to $\mathrm{H}$. $\mathrm{H}$. first becoming interested in cheapening postal communication is almost too well known to bear repetition. When quite a 


\section{I74}

SIR JOHN HENNIKER HEATON

young man, he was waiting in a village post office, and there his notice was attracted by an old woman in deep distress. She had just learnt that the postage to Australia was sixpence, and was therefore unable to post the letter she had written to her son. H. H. paid the money for her, and many months later he heard that the son had sent $£ 5$ to his mother, and had begun to write home regularly.

Later on, when $\mathrm{H}$. $\mathrm{H}$. was living in the wilds of the Australian Bush, he was able to appreciate the advent of the English mail. He knew as other exiles know the bitter disappointment of riding into the township, perhaps thirty or forty miles distant, only to find there was no letter from home. In those days the heavy postage was a consideration for those in England, and a consideration that frequently deprived the emigrant of a letter. H. H. was fond of quoting A. B. Patterson's verse descriptive of a Way-Back postal service:

\section{"Your letters and exchanges \\ Come by chance across the ranges, \\ Where a wiry young Australian \\ Leads a pack horse once a week. \\ And the good news grows by keeping, And you're spared the pain of weeping \\ Over bad news when the Mail-man}

Drops the letter in the creek."

It was in 1886 , soon after he entered Parliament, that $\mathrm{H}$. H. moved a resolution in the House of Commons inviting the Government to enter into negotiations with other Governments with a view to the establishment of a Universal System of Penny Postage. The motion was opposed by the Government, on financial grounds, and was defeated. The whole idea was 
looked upon as that of a visionary and a dreamer. The Hon. Member who seconded the resolution was so carried away by his enthusiasm that he bashed down the tall hat over the eyes of the Member sitting below him-an unfortunate occurrence that never fails to evoke merriment from both sides of the House. Such was the inauspicious opening of the campaign. His resolution indeed was defeated, but not so $\mathbf{H}$. $\mathbf{H}$. He began a crusade that was to last the remainder of his life. He travelled all over the world preaching Penny Postage, in season and out of season, and leaving no stone unturned that might directly or indirectly further his object.

In this brief summary, I despair of giving any adequate description of the persistent warfare waged against red-tape and officialdom. Only those in H. H.'s immediate circle could know the bitter hostility and ridicule he met with in quarters from which he might reasonably have expected support. Worse still, he had to overcome the absolute apathy that pervaded the public mind on all questions of the post office. Well might he exclaim with Macaulay, "There is more interest taken over the murder of a single policeman in Whitechapel than in a war with China." It was a red-letter day in H. H.'s career when the "Times" came to his support and lent its powerful influence to the cause. Strong leaders were written advocating Imperial Penny Postage, and their loyal and generous support throughout the years did much to shorten the battle and to snatch a victory in the teeth of opposition.

Fortunately, H. H. had to an unusual extent the gift of journalism, a gift which enabled him to present his case in a manner that was interesting to the outside 
public. Although he had at his finger tips unlimited statistics, he always endeavoured to illustrate his facts with some striking picture of common life : the lonely settler reading his Christmas mail, or the old folks at home receiving a money order from their son abroad.

By 1890 , he had succeeded in reducing international postage from sixpence to twopence halfpenny, a compromise that found little favour in the eyes of the reformer, who considered twopence halfpenny an inconvenient sum for a nation that does not use decimal coinage.

In granting permission for the reprinting of a passage from his book, Sir Charles Bruce writes :

"The present peril of the Empire is an eminently appropriate moment for the publication of reminiscences of Sir John Henniker Heaton. They afford encouragement in reminding us what can be and has been accomplished by one single man, by sincere, strenuous, and steadfast devotion to one imperial cause; and above all, the circumstances of the war bring home to every household the use and service of cheap communication by post and wire."

The passage referred to is taken from that monumental work of Imperialism, "The Broad Stone of Empire," by Sir Charles Bruce, G.C.M.G., which gives the following account of the fight for Penny Postage :

"In July, I895, Lord Salisbury formed his second government, and the appointment of Mr Chamberlain as Colonial Secretary was announced, the Duke of Norfolk being Postmaster-General. In February, I896, Mr Henniker Heaton laid before Mr Chamberlain the case for Imperial Penny Postage. His opening words were : 
" II is already apparent that you have set before yourself the task of giving effect, so far as may be practicable, to that feeling in favour of closer union between the mother country and the colonies, which is growing in intensity all over the Empire.

What we want is some cheap and ready means of bridging over the chasm of distance between our people and the millions of their colonial kindred, of restoring the broken arch in their communications and the severed link in their sympathies, of weaving the innumerable delicate threads of private and family affection into a mighty strand that shall bind the Empire together, and resist any strain from our foes or the Fates. We want it now, while we are threatened ; now while crafty rivals would replace us, and our wares and our rule; now while our far-off kinsmen are showing us in touching and inspiring fashion their loyalty to the Queen and their love for the Old Country. Such a measure as we are discussing would be instantly understood as Britannia's reply to all this love and loyalty; not only in colonial exchanges and marketplaces, but wherever a British axe rang in a clearing, or a British hunter stalked the wilds ; aye, and in the closets of European statesmen, too. The time is opportune; all we want is a Minister who will seize the opportunity from which our Post Office has turned away.

"This appeal was not thrown away. Next year, on the occasion of the Queen's Diamond Jubilee, the colonial Premiers were assembled in London, and met Mr Chamberlain on June 24th, I897, when the English Minister made the following memorable declaration :

"I should also mention the desire which is widely felt, and which I share, for an improved postal communication with the colonies. I believe that that matter rests entirely with the colonies themselves, and that they have revenue difficulties in the matter 
which have hitherto prevented us from coming to any conclusion. But I confess that I think that one of the very first things to bind together the sister nations is to have the readiest and the easiest possible communication between their several units, and as far as this country is concerned I believe we should be quite ready to make any sacrifice of revenue that may be required in order to secure a universal penny post throughout the Empire.'

"The Conference of colonial Premiers was followed in the same year by a quinquennial Congress of the Postal Union at Washington. At this Congress the foreign delegates, keenly alive to the fact that every reduction of postage must develop British commerce, voted against a Postal Union penny-rate as one man. The British Post Office at once took advantage of the opportunity to revive a suggestion made originally by Sir Rowland Hill in I837, and renewed by Sir James Fergusson in I8gI. They proposed to the Colonial Post Offices the establishment of an imperial twopenny postage rate. The response of Canada to this proposal was the announcement that from January Ist, $\mathrm{I} 898$, the Canadian domestic rate of $\mathrm{I} \frac{1}{2} \mathrm{~d}$. would extend to correspondence to every part of the Empire. The British Post Office protested that this could not be done without the consent of the rest of the Empire; and, still hoping to force its twopenny rate on the colonies, it proposed a Conference on the subject.

"This Conference met in London, at the Westminster Palace Hotel, on June 28 th, and on July 5 th and I2th, I898. The delegates included the Duke of Norfolk as Postmaster-General (Chairman), and an imposing array of Postmasters-General and representatives from the colonies and India. It was the only Conference of Postmasters-General of the Empire that has ever been held in London. For the following account of the proceedings I am indebted to Mr Henniker Heaton. 
"At the first meeting the Secretary of the Post Office set forth the familiar objections of the Department to the penny-rate ; and the inference naturally drawn by the colonial delegates was that the Home Government had receded from Mr Chamberlain's offer. The Australian delegates accordingly announced that they could not accept any reduction of postage. This roused the delegates of South Africa, who offered to support a uniform penny-rate; and Mr Mulock, for Canada, instantly closed with their proposal.

"The British officials then put up the Duke of Norfolk to recommend the delegates, in a fatherly way, to compromise their conflicting views by accepting the happy medium of the twopenny rate. Mr Mulock, however, formally proposed penny postage for all parts of the Empire that might be disposed to accept it.

"At the third meeting the attitude of the Home Delegates to the question of imperial postage had undergone a transformation. The Duke of Norfolk finally announced that the Government gave its unqualified support to the proposal of imperial penny postage. And so ended the struggle between $\mathrm{Mr}$ Chamberlain and the Post Office."

July of 1898 saw the initiation, though not the completion, of penny postage throughout the Empire.

In later years $H$. $H$., when asked what was the happiest time of his life, invariably spoke of the moment when he scribbled the following hasty notes to his wife :

Urgent and Express.

House of Commons,

My DEAR LitTLE WifE,

3 P.M. I2th July, I898.

I think we have won. The message to me confidentially is " I think you will be pleased, although not all you wanted." J. HENNiker Heaton. 
Urgent and Express.

My DEAREst Rose,

House of Commons,

9 P.M. I2th July, I8g8.

I have heard the following will appear in the morning papers: "Imperial Penny Postage for the Empire, except Australia, has been agreed to."

It is almost too good news.

Affectionately yours,

J. HENNIKER HEATON.

To the Duke of Norfolk, as Postmaster-General, fell the duty of conveying to Queen Victoria the news of the introduction of Imperial Penny Postage.

"When does this come into force?" inquired Her Majesty.

"We thought of the Prince's birthday," replied the Duke.

In an instant the Queen, ever mindful of her supreme authority, had drawn herself up.

"And what Prince?" she inquired in her most icy tone.

But the Duke was quite equal to the emergency.

"The Prince of Peace, ma'am-on Christmas Day," he replied quickly.

Thus it came about that penny postage was established on Christmas Day, I898.

$\mathrm{H}$. H. writing to a correspondent, Mr John Wilson, of Birmingham, expressed himself in these words :

"When the story of how we won imperial penny postage comes to be written, it will be found that had it not been for your great representative Mr Chamberlain we should have had to wait many years for the beneficent reform. I never realized the strength of purpose-his sympathy for the poor, the hard- 
working people of this country with relations abroaduntil the opportunity came for benefiting them by means of cheap postage. The mandarins at St Martin'sle-Grand had the worst half-hour they ever had in their lives in trying to measure swords with the powerful Minister.

"Mr Chamberlain determined that the people should have the boon, and he was ably seconded by my friends Mr Mulock, P.M.G. of Canada, Sir David Tennant, Agent-General for the Cape of Good Hope together with Sir Walter Peace, Agent-General fo. Natal."

H. H. never felt satisfied that sufficient credit was given to $\mathrm{Mr}$ Chamberlain for his share in the establishment of penny postage. Some words to that effect he wrote to Mr Chamberlain and received the following reply :

Dear Mr Henniker Heaton,

I do not care a brass button who gets the credit for the postal reform. The great thing is that the matter has been at last brought to a satisfactory stage, and I think that you and I are well content with the results without wishing for special notice.

Believe me,

Yours truly,

J. Chamberlain.

A leader in "The Times" paid a remarkable tribute to the success of H. H.'s labours :

"Henniker Heaton is in reality the Marconi of this new telegraphy of hearts. By bringing the postage of the Empire within the reach of the poorest he has rendered vocal innumerable chords which have long been dumb, and acclaimed the unity of the Empire by the responsive chorus of myriads of gladdened 
hearts. Christmas is a peculiarly fitting season for the spread of these glad tidings throughout the Empire, for, after all, the true spirit of Christmas is the outgoing of human brotherhood and affection. We do no more than express the sentiments of Englishmen in all parts of the Empire when we offer Mr Henniker Heaton a hearty Christmas congratulation on the happy inauguration of a really great stroke of Imperial policy."

That no man is a prophet in his own country H. H. was destined to prove. It was not until 1905 and after the most strenuous fight that $\mathrm{H}$. $\mathrm{H}$. was able to post a penny letter to Australia, and it was in IgII that he had the pleasure of receiving the first letter from Australia bearing a penny stamp.

The story of how we won penny postage to Australia is set out in a chapter by itself, and bears eloquent testimony to that great Imperialist, Sir Joseph Ward, and the splendid work accomplished by Mr Austin Chapman, Postmaster-General of Australia. Not content with his successful advocacy of imperial penny postage, $\mathrm{H}$. H. was engaged, in I905, in establishing a league for universal penny postage. The following appeal was sent out in his name and secured enthusiastic replies from every quarter of the globe.

\section{UNIVERSAL PENNY POSTAGE}

\section{AN APPEAL}

SIR, Aug. I0, I905.

It is intended to form a League for the establishment of Universal Penny Postage, so that any inhabitant of our planet, white, black, or yellow, 
may be enabled for the sum of one penny to communicate with any other, at the lowest possible rate and the highest attainable speed : Englishman with Frenchman, German, Italian, or Russian; European with American; Asiatic with Australian or African; so that when one soul has something to say to another neither colour, nor religion, nor greed, nor diplomacy, nor national antipathy, nor latitude, nor longitude, nor poverty, nor any other barrier shall stand between them.

The hour has struck for this grand yet simple assertion of the brotherhood of nations; of a change which threatens no interest, and benefits all mankind. Since I898, when Imperial Penny Postage was introduced, our outward mails have nearly doubled. Every Friday some 250,000 British letters pass through France and Italy for India, Hong-Kong, and Australasia-I2,000 miles. The postage on each of these letters is Id. By the same boat a few British letters are carried for residents in Calais-2I miles; and on these letters the postage is $2 \frac{1}{2} \mathrm{~d} . !$ By what perverse ingenuity can such a distinction be justified ? Or why should a letter to New York cost $2 \frac{1}{2} \mathrm{~d}$. and another in the same bag be carried through that city and Iooo miles into Canada for Id. ?

That thought can be fairly taxed at a customhouse none will affirm. Opium can be weighed, whiskey tested. But what scales are delicate enough to weigh the products of the human mind ? That an English letter should be taxed because it is addressed to a Frenchman is a policy unworthy of the age. This is not an argument for the benefit of the "foreigner," since a letter benefits not only the addressee, but even more the sender. And if so, can it be contended that Io,00o letters sent to Canadians benefit us more than as many addressed to Americans ! I maintain that the trade and commerce resulting from cheap postage will amply compensate for any initial loss. 
That the moment for action has arrived is indicated by the fact that my friend, Sir J. G. Ward, PostmasterGeneral for New Zealand, is to move a Resolution for Universal Penny Postage in the Postal Union Congress at Rome next year. It cannot be too soon or too clearly shown that this doughty reformer is speaking with the public opinion of the mother country behind him.

To you, as one of those to whom our people look for guidance in great questions, I appeal for sympathy and support. I ask you to enrol your name in our League, and, if convenient, to give us a few words of encouragement.

Without venturing to introduce the Sovereign's name in this appeal, we may confidently assume that no movement which aims at bringing the peoples of the earth into more frequent and closer correspondence and friendly intercourse can be indifferent to King Edward VII., and that we have His Majesty's silent good wishes.

$$
\begin{aligned}
& \text { I am, } \\
& \text { Yours faithfully, } \\
& \text { J. HENNIKER HEATON. }
\end{aligned}
$$

H. H.'s insatiable demands brought forth a mild protest from the Postmaster-General, Lord Stanley:

"I must say I was rather in hopes that, when I had met your wishes regarding Australian penny postage, I should not be called upon during my time of office again to enter into a struggle with you. However, I am quite sure we can fight and still remain friends."

Lord Roberts wrote :

Dear Mr Henniker Heaton,

I have received your letter about the establishment of universal penny postage, and am very glad you are moving in the matter. 


\section{AS A POSTAL REFORMER}

I shall with pleasure enrol my name in your league, and I trust that your efforts in this direction may be as successful as they were in 1898 in getting imperial penny postage established, which has proved such a boon to the Empire.

\section{Believe me,}

Yours very truly,

ROBERTS.

Sir Wilfrid Lawson sent the following lines:

Dear Henniker Heaton

You never are beaten,

But stick to your project like bricks.

And this your last dream

Most worthy I deem,

So my name you may freely affix.

What a world it would be,

Which some may yet see,

When a penny such wonders will work.

And think of our delight

To write day and night

To American, Frenchman, or Turk.

What scope there will be

For fellows like me

To send letters, and poems, and stories,

Including full streams (reams)

On that best of all themes,

A tremendous abuse of the Tories.

But dear Mr Heaton,

This world you will sweeten

By the project you now have in view.

It is perfectly clear

'Twill bring nations near,

And what better thing can you do? 
From the Dean of Norwich :

My dear Henniker Heaton,

Universal Penny Postage is due to humanity. England, as the mother of millions, should facilitate the commerce of her children with those of all lands. Interchange of thought smooths the angles of insularity, clears the sympathy; it deepens and strengthens mutual respect. It will be the meanest expression of the peddling spirit if the broad and bright reforms you have initiated, and intelligence now desires, are hindered by official parsimony. The great England of to-day should set this matter going. Other nationalities would follow her lead. The old song of Deborah should be chanted as your enterprise expands, "The leaders took the lead and the people willingly followed." We should not suffer this honour to be won by any other power on earth. You have done wonders, and I heartily hope the blessing of Heaven may crown your untiring diligence, your intelligent enthusiasm, your inspiring courage, and your unifying universalism. I'll gratefully join the League.

Ever yours,

W. LEFROY, D.D.

That H. H. did not live to see the adoption of his cherished ideal of Penny Postage to France must be accounted almost a tragedy, so dearly longed for was this project.

On July I4th, I908, H. H. led a large deputation to the Prime Minister to ask that Penny Postage might be established between France and England. Mr D. V. Pirie, M.P., handed in a list of 4IO members of Parliament pledged to vote for Anglo-French penny postage. He stated that the list comprised 2ro Liberals, Ioo Unionists, 50 Nationalists and 50 Labour Members. 


\section{Ten Excellent Reasons for Anglo-French Penny Post. Compiled by H. $\mathrm{H}$.}

I. There are $42,000,000$ people in Great Britain and Ireland, and 40,000,000 in France. A narrow channel 2I miles across separates these two great and friendly nations. Surely the British and French postal authorities still have energy enough to bridge this chasm-a chasm stretching apart into the blue distance, like the two sections of the gigantic Roman aqueduct in the Campagna that want a central connecting arch, or like the two sections of an alpine tunnel before they are united.

Penny or ten centimes postage exists throughout the British and French Empires, embracing a population of 490,000,000 and an area of $14,600,000$ square miles.

2. At present the postage is one penny to Fiji, II,000 miles from London; and the postage to the Society Islands, I0,500 miles from Paris, is ten centimes, or one penny. Yet it is $2 \frac{1}{2} \mathrm{~d}$, or 25 centimes, between Dover and Calais, $2 \mathrm{I}$ miles. We are like people conducting two parallel railways under rival ownership. The commercial and social benefit predicted from a costly Channel Tunnel could be secured at once by a stroke of the pen, establishing an AngloFrench Postal Union without alarming any military strategist.

3. Last year we sent to France $12,600,000$ letters, and received from France $12,000,000$ letters. We sent to France $\mathrm{I}, 500,000 \mathrm{lb}$. of printed matter, and received from her $1,092,000 \mathrm{lb}$. of printed matter. There were also sent through France to and from the East and Australasia, 24,000,000 British letters and 8,200,000 lb. 
of printed papers. The postage on the letters to and from France near at hand was $I \frac{1}{2}$ times heavier than on those sent through France to Australasia, I2,000 miles. But the rate of postage on the printed papers was the same from England to France, as from England to Australia. Yet mail-bags containing letters, and mail-bags containing printed papers, are not distinguishable except by experts, and receive exactly the same care and treatment.

4. The imports from and exports to each other of England and France amount to $£ 69,000,000$ (I,725,000,000 fr.) The present high foreign postage is in effect a tax on the exports of each countryinjurious to both.

5. Under Clause 2I of the Postal Union any two States might establish lower postage between themselves by forming a Restricted Union. Several pairs of States (e.g. Austria and Germany, Canada and the United States, Mexico and the United States) have formed such unions with penny postage. Why should not England and France form one ?

6. The French postal authorities have expressed a desire to discuss postal rates with our Post Office. The British officials have admitted that the $2 \frac{1}{2} \mathrm{~d}$. rate is too high, but still wish to charge $2 \mathrm{~d}$., or twice as much for sending a letter across the Straits of Dover to Calais as across St. George's Channel to Dublin, or across the Mediterranean to Algiers. The postage level being the same on both sides, the Channel tax is as absurd as would be locked gates in the Suez Canal, as exasperating as would be a toll-gate in Cheapside.

7. The Anglo-French Postal Union, similar to the Austrian-German, American-Canadian, and other 
unions, would not require a single additional ship, train, horse, cart, or man. The machinery is now ample. The 12,000,000 letters from France would not count beside the 2,624,000,000 inland letters now dealt with by our British Post Office, more than an additional rivulet flowing into the Thames.

8. No less than 780,000 passengers cross the Channel every year-all good customers of the Post Office. British children to the number of many thousands are educated in France, and we have colonies of English residing in that sunny clime; while there are also thousands of French people in our foggy land, who would all write five letters at a penny for one letter at the present high rate.

9. Penny postage would cost neither country one penny more than is at present expended. It would bring a rich harvest of trade and good feeling. The estimated minimum increase of letters would cover the cost in a remarkably short period.

Io. An Anglo-French Postal Union would be a graceful, opportune, and popular demonstration of "l'entente cordiale," a practical, substantial fulfilment of the kindly aspirations of the two peoples, so eloquently expressed by representative men; a stimulus to commerce, a boon to all, a memorial of the greatest achievement of Edward the Peacemaker.

When, in I9Io, Lord Blyth issued a circular letter inviting Members of the House of Lords to express their views on Franco-British Penny Postage, 230 signified their desire for the reform ; and Lord Dartmouth in his reply summed up the matter succinctly:

"For those will write

Who never wrote before.

And those who wrote

Will only write the more." 
In the same year, $\mathrm{H} . \mathrm{H}$. and Lord Blyth visited Paris on a mission that created great interest and enthusiasm. Before leaving London they had an interview with the French Ambassador, M. Cambon, who expressing his fervent good wishes for the cause, gave them letters of introduction to the chief French ministers. On arrival in Paris, H. H. and Lord Blyth were met by a body of members of the Chamber of Commerce, led by Sir Joseph Walton. The French Postmaster-General, M. Brian, M. Emil Dupont, and, in fact, every Minister approached, and every man of any position, warmly advocated the immediate adoption of Franco-British Penny Postage. It is almost inconceivable that a great country like England should allow the consideration of a possible loss of revenue to outweigh the advantages of the only practical proof of the entente cordiale.

Colonel Sir Arthur Davidson wrote, from Biarritz, on the 24th March I9Io:

Dear Mr Henniker Heaton,

Many thanks for your letter and enclosures. Although, as you say, the question of Penny Postage between France and England is a non-party matter, there are, still, possible international jealousies and difficulties ambushed under such an arrangement: and this being the case, it would be a delicate matter for the King to speak to the Chancellor of the Exchequer on a question affecting France and England only: when other nations-Germany, for instance, might wish to retain the present $2 \frac{1}{2} \mathrm{~d}$. rate, and would resent the proposed arrangement as interfering with the International postal balance.

This would cause a complication in which it is best that the King should not be included, or have initiated. 
You are certainly tireless about postal reform, and have good reason to be gratified with what you have already obtained.

I remain,

Yours very truly,

ARTHUR DAVIDSON.

In this year I9I6, it is not too much to hope that a few months' time will see the adoption of this necessary reform.

In I908 H. H. achieved another triumph in the introduction of penny postage to the United States. The battle was not won without a long and weary campaign. In 1890 he visited America to confer with the Postmaster-General, the Honourable John Wanamaker, on the possibility of establishing an Anglo-America Penny Post. The final adoption was largely due to Mr Wanamaker's advocacy and practical help long after he had ceased to be Postmaster-General. The names of $\mathrm{Mr}$ Roosevelt, $\mathrm{Mr}$ Andrew Carnegie, the American Ambassador, Mr Whitelaw Reid, Lord Blyth, Mr Baxter, and last and chief, Mr Meyer, will be held in grateful memory by the letter-writing public of the two nations.

On July 3rd, I906, a deputation of 108 members of the House of Commons, 24 ex-Members, Senator the Hon. Nicholas Longworth of the United States, many Peers, Bankers, and Presidents of Chamber of Commerce assembled in the Grand Committee Room of the House of Commons to meet the Right Hon. H. H. Asquith, Chancellor of the Exchequer, and the Right Hon. Sydney Buxton, M.P., Postmaster-General.1 The Chancellor of the Exchequer and the Postmaster-

1 Viscount Buxton. 
General expressed themselves as favourable to the object, but regretted that the finances of the country did not then admit of the additional expenditure. America was anxious from the first to adopt AngloAmerican Penny Postage, but England held back on the plea of loss of revenue. An offer was made by $\mathrm{H}$. H., Lord Blyth, Mr Andrew Carnegie, the late Sir Edward Sassoon, and $\mathrm{Mr}$ John Wanamaker to guarantee the loss of revenue for the first five years; but this offer was refused.

In $1907, \mathrm{H}$. $\mathrm{H}$. was travelling in Australia when he received a letter from Mr George Meyer, the progressive P.M.G. of the United States, expressing his anxiety for the establishment of an Anglo-American Penny Post. Immediately on receipt of this letter, H. H. sent a long cable to Mr Meyer, and caught the next ship back to England in order to pursue the campaign.

In I908 the Franco-British Exhibition was held in London. Lord Blyth was Chairman of the Organizing Committee, and $\mathrm{H}$. H. suggested to him that it would be a fitting moment while President Fallières was in London to approach the P.M.G. with renewed demands for a Franco-British Penny Post. Accordingly Lord Blyth-who, following H. H.'s action in the House of Commons, had prepared a similar list of members of the House of Lords in favour of Penny Postage to France-addressed a letter to the P.M.G. strongly urging its adoption. The P.M.G., Mr Sydney Buxton, wrote to him privately saying that it was a most inopportune moment as the P.O. was already considering penny postage to America and the exploiting also of the claims of France would jeopardize both projects. 

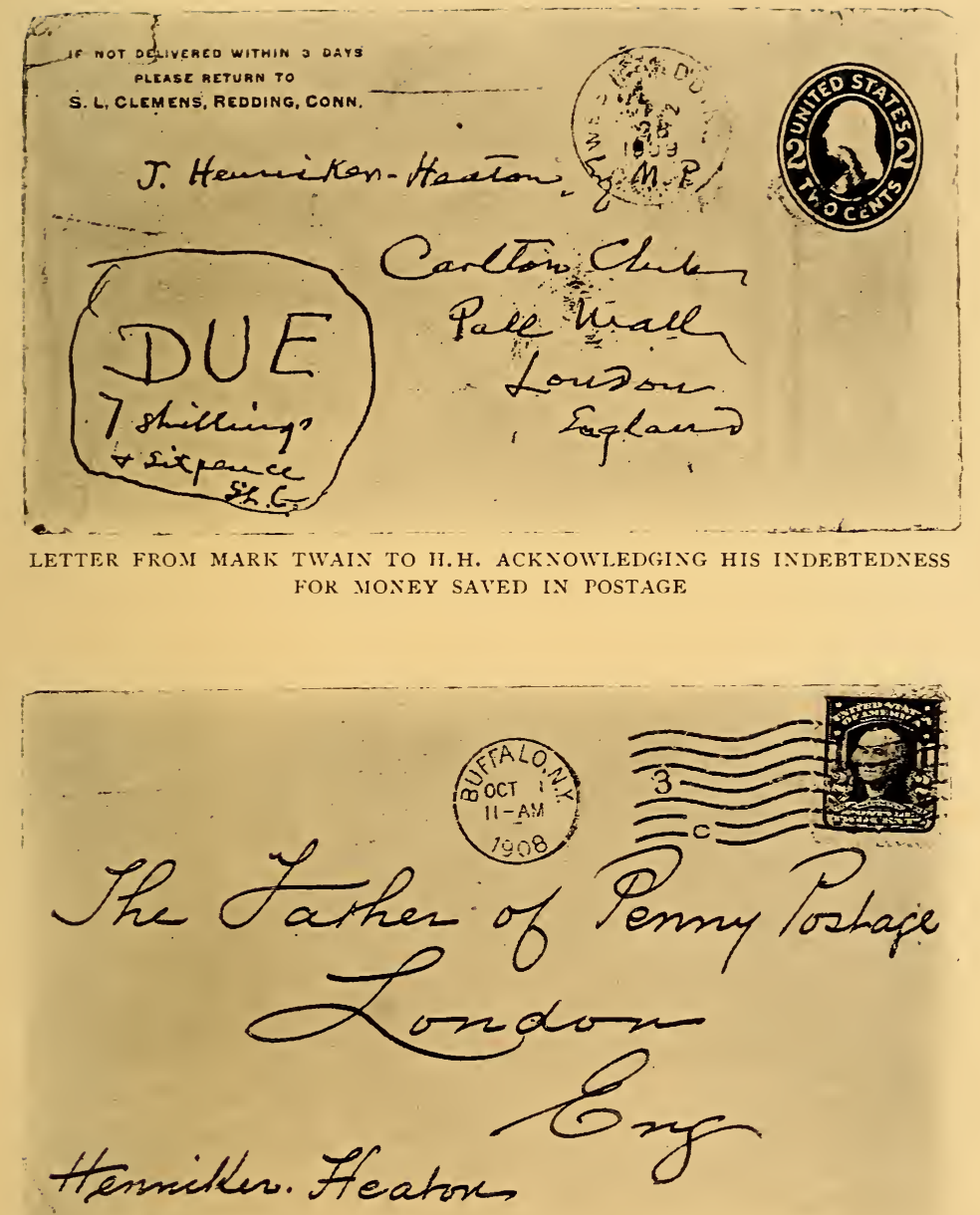

Herritles. Feature

FIRST LETTER FROM AMERICA TO ENGLAND BEARING A PENNY STAMP 

Lord Blyth, after conferring with $\mathrm{H}$. H., wrote to the P.M.G. that under those circumstances he withdrew all demands for Franco-British Penny Postage as he considered America should come first; at the same time he wrote to $\mathrm{H}$. $\mathrm{H}$. the words which became historic in all future postal campaigns, "One step enough for me."

Mr Sydney Buxton, who had consistently supported the movement, was at the same time submitting the question to his colleagues of the Cabinet, though naturally he was not at liberty to mention the fact to Lord Blyth or to $\mathrm{H}$. $\mathrm{H}$.

A few days later, at a luncheon given at the Guildhall to meet President Fallières, Mr Buxton came up to Lord Blyth to tell him that his hopes of establishing Penny Postage with America were at an end, as, although he had cabled to America on behalf of the British Government that England was now ready for its adoption, he had received no reply.

Lord Blyth immediately got into telephone communication with $\mathrm{H}$. H., who suggested they should see the American Ambassador, Mr Whitelaw Reid, without delay. At ten o'clock the next morning, H. H. and Lord Blyth called on Mr Whitelaw Reid, and showed him the whole correspondence that had taken place over a course of years. Mr Whitelaw Reid had always been a strong supporter of the movement and offered his services without reserve.

"What do you wish me to do ?" he asked of H. H.

"We want you to send a telegram to the President to the effect that if America does not immediately agree to the adoption of Penny Post, France will obtain the boon before our English-speaking people," replied $\mathrm{H}$. $\mathrm{H}$. 
That Mr Whitelaw Reid more than fulfilled his promise may be gathered from the fact that two days later $H$. H. received a private letter from the P.M.G., stating his intention of making an interesting announcement in the House of Commons the following day :

My dear Henniker Heaton,

In all probability I shall utter a statement at end of questions to-morrow (Wednesday) which will be of great interest to you.

I let you know as you may like to be present.

Yours ever,

SydNEY Buxton.

Mr Whitelaw Reid also wrote to Lord Blyth :

MY DEAR LORD BLyTh,

Now that the matter is substantially settled

I think I may, without impropriety, tell you confidentially, and authorize you to mention to $\mathrm{Mr}$ Henniker Heaton, that I received a despatch on May 3oth from the Secretary of State, in reply to the communication I promised you to make. In this Mr Root said that the Postmaster-General was then absent for the week-end but the understanding was that no obstacle remained to an agreement upon a new postal arrangement with Great Britain on his return June Ist. I think Mr Buxton will also be ready to give you some cheerful information soon.

Believe me,

Yours sincerely,

WHITELAW REID.

On the night of September 30th, I908, H. H. dined with one of his sons at the United Service Club, and sat, after dinner, in a fever of impatience as the hands of the clock slowly crawled round to midnight. As the clock finished striking $\mathrm{H}$. $\mathrm{H}$. had the satisfaction 
of posting half a dozen letters to America bearing the penny stamp. It was no small gratification to $\mathrm{H}$. $\mathrm{H}$. to receive a letter of congratulation from $\mathrm{Mr}$ Roosevelt posted likewise in America just after midnight. Some time later $\mathrm{H}$. H. met $\mathrm{Mr}$ Roosevelt at the Guildhall in London.

"It was a very great pleasure to me to post you that letter," said Mr Roosevelt.

"Yes," replied H. H., " but why did you put a twopence-halfpenny stamp on it?"

\section{A letter from Mark Twain ran as follows :}

Dear Henniker Heaton,

I do hope you will succeed to your heart's desire, in your cheap cablegram campaign, and I feel sure you will. Indeed your cheap postage victory, achieved in spite of a quarter century of determined opposition, is good and national prophecy that you will. Wireless, not being as yet imprisoned in a Chinese wall of private cash and high placed and formidable influence, will come to your aid and make your new campaign briefer and easier than the other one was.

Now then, after uttering very serious words, am I privileged to be frivolous for a moment ?

When you shall have achieved cheap telegraphy, are you going to employ it for just your own selfish profit and other people's pecuniary damage, the way you are doing with your cheap postage? You get letter-postage reduced to 2 cents an ounce. Then you mail me a 4 ounce letter with a 2 cent stamp on it, and I have to pay the rest of the freight at this end of the line. I return your envelope for inspection, look at it, stamped, in one place, is a vast " $T$," and under it the figures of " 40 " and under those figures appears an " L," a sinister and suspicious and myster- 
ious L. In another place, stamped within a circle, in offensively large capitals, you find the words "DUE 8 CENTS."

Finally, in the midst of a desert space up nornor-eastward from that circle you find a figure " 3 " of quite unnecessarily aggressive and insolent magnitude-and done with a blue pencil, so as to be as conspicuous as possible. I inquired about these strange signs and symbols, of the postman. He said they were P.O. Department signals for his instruction.

"Instruction for what?"

"To hog extra postage."

"Is it so? Explain. Tell me about the large $T$ and the $40 . "$

"It's short for take 40-or as we postman say, hog $40 . "$

"Go on, please, while I think up some words to swear with."

"Due 8 means, hog 8 more."

"Continue."

"The blue pencil 3 was an afterthought. There aren't any stamps for afterthoughts - the sums vary according to inspiration, and they whirl in the one that suggests itself at the last moment. Sometimes they go several times higher than this one. This one only means hog 3 cents more. And so if you've got 5I cents about you, or can borrow it___."

"Tell me: who gets this corruption ?"

"Half of it goes to the man in England who ships the letter on short postage, and the other half goes to the P.O.D. to protect cheap postage from inaugurating a deficit."

"I can't blame you; I would say it myself, in your place, if these ladies were not present. But you see I'm only obeying orders, I can't help myself."

"Oh, I know it; I'm not blaming you. Finally, what does that L stand for?" 
"Get the money, or give limit. It's English, you know."

"Take it and go. It's the last cent I've got in the world.."

After seeing the Oxford pageant file by the grand stand, picture after picture, splendor after splendor, three thousand five hundred strong, the most moving and beautiful and impressive and historically instructive show conceivable, you are not to think I would miss the London pageant of next year, with its shining host of I5,000 historical English men and women dug from the musty books of all the vanished ages and marching in the light of the sun all alive, and looking just as they were used to look! $\mathrm{Mr}$ Lascelles spent yesterday here on the farm, and told me all about it. I shall be in the middle of my $75^{\text {th }}$ year then, and interested in pageants for personal and prospective reasons.

I beg you to give my best thanks to the Bath Club for the offer of its hospitalities, but I shall not be able to take advantage of it, because I am to be a guest in a private house during my stay in London.

Sincerely yours, Samuel Clemens. 


\section{CHAPTER XIV}

\section{AS A POSTAL REFORMER (continued)}

"The Post Office Annual Report gives one great food for thought, for it shows that every man, woman, and child in the United Kingdom gets on an average rio Postal Packets every year. That is $45,000,000$ people get $5,400,000,000,000$. Another interesting fact is that in 1840 the average number of letters received by the people of this country was 7 , and in 1912 the average number of letters received by each individual is 70 , or ten times more. I do not think the population is more than double that of $1840 . "$

J. HeNNiker Heaton. 1912.

“

"F I give way to Henniker Heaton on a single point he is on my doorstep the next morning with fifty more," said $\mathrm{Mr}$ Asquith, summing up in that one sentence the secret of H. H.'s successful warfare.

H. H. could afford to give his genial laugh when acquaintances spoke of him as a "lucky man"-a phrase chiefly employed by those who sleep while others wake, who rest while others toil.

"Keep on pegging away and you will win," wrote the Duke of Argyll, who knew something of H. H.'s persistent methods of attack.

"Be a Paganini-play on one string," was H. H.'s advice to ambitious young men entering Parliament, and he certainly lived up to his teaching. Year after year, he fiddled away on his one string outside the portals of St Martin's-le-Grand, regardless of all requests to move on. Postmasters came and Postmasters went, and still that one string called Reform sounded through the halls by day, and disturbed dreams by night. Postal officials suffering under 
H. H.'s bludgeonings and relentless criticisms must have felt there was something almost uncanny in his dexterous use of weapons : to-day cudgels and broadswords; to-morrow ridiculous pin-pricks none the less galling.

The stolid stubborn resistance $\mathrm{H}$. $\mathrm{H}$. met with made no more impression on his mind than the solid rock can hope to make upon an incoming tide. Sooner or later, little by little, the foundations will be washed away: to-day a gentle lapping of the waves; tomorrow the breakers bursting in full force. Opposition H. H. could and did enjoy, and the reasons given for refusing to support his benevolent enterprises were sometimes amusing. One writer stated solemnly that the fewer opportunities nations had of knowing each other, the fewer opportunities would they have of quarrelling, and ended by citing Iceland in support of this theory. An abusive letter reached $\mathrm{H}$. $\mathrm{H}$. from Australia, wherein the writer complained that the introduction of penny postage had let loose a flood of correspondence from his poor relations in County Clare, trying to borrow money from him!

That Penny-a-Word Telegrams would further destroy the privacy of modern life was the reason put forth by Sir Arthur Bignold in a letter to his friend :

“' I must own up to being an 'impossible,' inasmuch as my most fervent hope is in the direction of being let alone and not improved, and I feel certain that an instantaneous penny-a-word telegraph service would land me in Hanwell right away.

"The Postal Service was the beginning of it, for until that was established there was a little peace. You saw your friend and bade him good-bye, and you could not quarrel with him until you met him again. The 
present railway system too-by which you are shot through the world like so many tons of coal, no one caring whether you come or whether you do not, except that there may be a certain weight of food cooked for you to eat-will not bear thinking of, and now, when the telegraph system had practically destroyed the peace and quiet of life, there are to be telephones to complete the charter of human rights.

To me it's all maddening, and will cause my immediate retirement to my Scotch mountains, to which, thank goodness, there is no legal access at present.

Believe me to remain,

Yours very faithfully,

ARTHUR Bignold.

P.S.-Still malgre tout I must support you.-A. B.

When H. H. entered Parliament in I886, he drew up a list of sixty reforms for the Postmaster-Generalmost of which were adopted ; when he left Parliament in I9Io, he drew up another list of sixty-two reforms -one for every year of his life.

By I89I, H. H. had already been instrumental in obtaining :

I. A saving of $£_{10} 7,000$ a year, or a total saving of $£ \mathrm{I}, 070,000$, on the cost of conveying mails to India and the East during the next ten years.

2. A saving of $f 40,000$ a year on the De la Rue Post Office stationery contract.

3. A saving of at least $£ 25,000$ a year on the Sample Parcel Post. Formerly tens of thousands of samples were sent from London to Belgium, to be posted back to England, and Belgium kept every farthing of the postage.

4. A saving of at least $£ 30,000$ a year in the carriage of mails to India, China, and Australia, overland from Calais to Brindisi. When $\mathrm{H}$. $\mathrm{H}$. commenced the 
agitation $I \frac{1}{2} \mathrm{~d}$. carriage for every letter was charged by the Governments of France and Italy. The charge was reduced to less than Id. per letter.

5. The introduction of post cards to and from Australia.

6 . The reduction of ocean postage to Australia from $6 \mathrm{~d}$. to $4 \mathrm{~d}$. per letter, and the reduction of postage to the Cape of Good Hope from 6d. to 4d. per letter.

7. Extension of the Parcel Post to France.

8. Introduction of the Telegraph Money Order into England.

9. Further reduction of postage to Australia from $6 \mathrm{~d}$. and $4 \mathrm{~d}$. to $2 \frac{1}{2} \mathrm{~d}$. per letter from January Ist, I8gI.

In the years that followed $\mathrm{H}$. $\mathrm{H}$. added continually to the list of concessions wrung from the G.P.O. Perhaps one that gave him most personal satisfaction was the abolition of charges on lost or delayed postal orders.

\section{Lost or Delayed Postal Orders}

To the Editor of the "Times."

SIR,-It was with supreme satisfaction I received from my bankers this morning a note informing me that they had placed to my credit the sum of $7 \mathrm{~s}$., being the amount of two postal orders for 3s. 6d. each collected from His Majesty's Government on Thursdayfourteen years after issue.

These two postal orders are familiar to the House of Commons, for I have exhibited them frequently during debates as examples of Post Office stupidity. The law was that any postal order not presented for payment within a period of three months of issue was subjected to a fine equal to the original amount paid for poundage, and so on for each additional three months. To the Postmaster-General I pointed 
out that this action was utterly indefensible. I asked him to remember that he makes a profit of from $£$ Io,000 to $£ I 2,000$ a year on lost postal orders, but not satisfied with that he levies a heavy commission on poundage of postal orders not presented for payment within three months. No Shylock of modern times charges interest on money deposited in his keeping. Yet on presenting these two postal orders for $3 \mathrm{~s}$. 6d., each drawn on November 5, I89o, the Post Office offered to pay them if $7 \mathrm{~s}$. 2d. was first paid for poundage! The holder had inadvertently left them in his desk, and found them two years ago. I had to tell our Postmaster-General that no Levantine Greek had ever dreamt of such rapacity as exhibited by his department in this case-that is charging Ioo per cent. for keeping the man's money and profiting by it.

I am glad to say Lord Stanley passed an Act last Session abolishing for ever the charge, and only exacting one extra poundage for a delayed postal order. I have relieved my pocket-book of my old friends, the two postal orders, and gone for ever is another legitimate grievance.

October 24th, I904.

Your obedient servant,

J. Henniker Heaton.

In looking over old papers of H. H.'s it is remarkable to see how greatly the relations between him and the postal officials were softened under the mellowing influence of time. Where there was at first only bitterness and strife--" the severe, the ascetic, the impregnable Mr Cecil Raikes" - at the end we find no small degree of mutual sympathy and the respect of worthy antagonists. It may be that the great factor-in public not less than in private lifepersonal acquaintance had something to do with the 
altered state of affairs. Was it not the Bishop of London who wrote, "Personal contact is the great solvent of all the difficulties in the world."

However it may be, H. H. numbered among his personal friends many of the mandarins of St Martin'sle-Grand, and entertained for at least one PostmasterGeneral feelings of warm affection.

The following obituary notice appeared in "St Martin's-le-Grand Magazine," written by the editor, Mr E. Bennett.

"I am quite sure that none of my readers regret more sincerely the passing away of Sir Henniker Heaton than his old opponents 'the mandarins' of the Post Office. He had in his time troubled us in season and out of season, and there was a peculiar venom in his methods which hindered rather than helped his reforms. But in the eighties and nineties, when Sir Henniker was at his best, or his worst, as a fighting man, it often seemed, even to those within the service, that something dynamic was required to upset the non possumus attitude of the Post Office administrator, and to bring home to the Treasury as well as to the Post Office the fact that the British Empire demanded a great deal more from those who were running the Department than the point of view of a retail shopkeeper.

"Mr Massingham has spoken of Sir Henniker as the 'most terrifically concentrated mind I ever met in a Member of Parliament.' That was indeed the secret of his success. He was a man who in public life had only one subject, and in pursuit of his aims he was untiring, obstinate, and often inconsiderate to his opponents.

"During the last few years I have been able to claim Sir Henniker as a personal friend and I have worked with him in an association unconnected with 
the Post Office. His public appearances gave no indication of his private charm. He was a delightful companion, an inveterate gossip, and he richly enjoyed both hearing and telling good stories. He was as staunch to his friends as he was to his policy, and he who used the bitterest language about his opponents in public was one of the kindest-hearted men I have ever met."

A warm friendship existed between $H$. $H$. and Sir Neville Borton, Postmaster-General of Egypt, and Saba Pasha. It was from the Egyptian Post Office that $\mathrm{H}$. H. took the idea of the little red book of stamps which is now in use in the British Post Office. When these books were first introduced in England, two shillings was charged for them, although stamps to the face value of only Is. II $\frac{1}{2} \mathrm{~d}$. were issued, a piece of economy on the part of the " meanest and greatest Post Office in the world" which brought down such vials of wrath from $H$. $H$. that the extra halfpenny was soon added, and the cost of the book was defrayed by using the interleaved pages for advertisement.

On October 2nd, IgI2, H. H. wrote to Mr Herbert Samuel :

My Dear Postmaster-General,

Your charming letter gave me much satisfaction. Your removal of petty annoyances, such as charging a halfpenny for a two shilling book of stamps, and a farthing for a halfpenny post card, entitle you to the blessings of the clergy, for men swore a good deal at the meanness of St Martin's-le-Grand. I have collected the answers of your predecessors for twentyfive years declining to grant the concessions you have made. I would like to publish the splendid result of 
selling the two-shilling booklet of stamps at face value.

With sincere regard,

Yours most faithfully,

J. Henniker Heaton.

Speaking of advertisements, a certain world-famous pill manufacturer once approached $\mathrm{H}$. $\mathrm{H}$. with an offer to pay the G.P.O. $£$ I5, 000 a year for the privilege of printing "Use —-'s Pills," on every postmark!

H. H. made no secret of the fact that he considered Mr Herbert Samuel the greatest Postmaster-General England has ever had. When $\mathrm{Mr}$ Samuel left the Post Office, in IgI4, H. H. wrote him the following letter, from Nice.

\section{My dear Postmaster-General,}

Your leaving the Post Office is to me a calamity.

The British people lose the best Postmaster-General, and I lose a singularly generous and noble-minded friend from that Department, far and away the most just and able administrator during the past thirty years.

You have removed scores of petty and worrying annoyances made by pettyfogging officials in former years. You have taken the first important steps for the reduction of telegraph rates to the Continent of Europe, and I know that you were on the point of carrying penny postage between France and England. Most sincerely yours,

J. Henniker Heaton.

Private.

I very much doubt if your new position gives you the opportunities you deserve of serving your country to its best advantage.

Health and strength to you in the years to come.

Your devoted friend,

J. Henniker Heaton. 
As is only fitting, P.M.G.'s seem to have a particularly pleasing gift of letter writing :

Dear Henniker Heaton,

My best thanks for your letter of the 5 th.

I hope you spend your days buying halfpenny post cards for halfpence, and penny letter-cards for pennies ! ${ }^{1}$

I will inquire about the charge on telegrams to Broadstairs and send you a reply shortly.

$$
\begin{aligned}
& \text { Yours very truly, } \\
& \text { HERBERT SAMUEL. }
\end{aligned}
$$

My dear Henniker Heaton,

I am glad that at last you have been willing to accept an Honour-you have certainly well earned it.

It is a satisfaction to me to know, and to feel, that for so many years, and especially during the time I was Postmaster-General, our relations were of such a friendly character ; and I was very sorry when you left the House.

At the same time, as I have more than once suggested to you, I am sure that you never gave sufficient credit to the desire on the part of the officials of the Post Office-not to speak of the Postmaster-Generalto carry out useful and satisfactory reforms. Every suggested proposal is not, of course, necessarily either useful or satisfactory.

It is easier to suggest reforms than to carry them out; and I remember, in this connection, quoting to the House, in one of my Estimate's speeches, the old saying that "anybody can turn up Genesis, but it takes an able-bodied man to find Hosea!"

The real fact is that, even though a postal reform may be a very good one, and be accepted in principle, time, money, and opportunity (especially where another

1 A reform just introduced. 
country, such as the U.S.A., has to be consulted and persuaded) have all to be found and to synchronize, in order to carry it through.

As Browning says :

"Never the time, and the place, And the loved one all together."

The difficulty in postal reforms is the same; but nevertheless reforms are carried through.

Yours sincerely,

SyDNEY Buxton.

Dear Mr Henniker Heaton,

I am so glad to hear-even in strict confidence - that you are in favour of confining circulars to printed matter.

All our troubles come from a departure from that principle; and I hope you will at once bring your great influence to bear in that direction.

Lord Londonderry and I have spent some time this morning in looking out a site here for the statue which the Post Office will at once erect in your honour. Very truly yours,

G. H. MurRay.

If it is not possible to follow the traditional path from "China to Peru," it is at all events possible to include letters from the Legations of China and Mexico :

\section{Dear Mr Henniker Heaton.}

I write to thank you for your letter and for the pamphlets which you have been so good as to send me.

I am in entire agreement with you that it would be of great service to my country to have a universal 
Penny Post, and I have little doubt that in time this desirable end will be brought about.

I shall have great pleasure in perusing the pamphlets, and should an occasion arise, shall lose no time in doing what I can to further the objects you name.

\section{Yours very truly,}

Li ChING-Fong.

MY DEAR SIR,

I have hailed with great satisfaction the announcement you make of a petition from influential persons in this country regarding the establishment of Penny Postage between Mexico and the United Kingdom endorsed by the British Government. Perhaps I may be able to carry it myself and lay it before the President of Mexico. I feel sure that will bring about the desired result, with the shortest possible delay. I scarcely need say that I will strive and do my best to help you in your very commendable work, which I consider a great honour.

Looking forward to the pleasure of talking with you about this matter either at the House of Commons, on the I2th, or before.

I remain,

Yours very truly,

M. Covarrubias.

H. H.'s daily letter bag was a large one, and the complaints that poured in upon him from unknown correspondents were a source of great help to him in attacking the Post Office. People who had failed to get satisfaction from the Post Office would appeal to him, and it was strange indeed if no benefit was derived from his assistance. At the time of the Boer War many relations of soldiers wrote to $\mathrm{H}$. $\mathrm{H}$. asking 
him to use his influence to get the parcel post reduced. To one of them he replied :

DeAR MADAM,

I have been endeavouring to persuade the mandarins at St Martin's-le-Grand to meet your views (and that of thousands of others) in regard to soldier's parcels. They blame the Treasury. I have a question down to-morrow in the House of Commons, and I have reason to believe that I shall get a sympathetic if I cannot get a favourable answer.

It would be a grand thing to convey all parcels for Tommy Atkins for Id. each.

Very sincerely yours,

J. Henniker Heaton.

H. H. was always interested in seeing any new invention for stamping postmarks or safeguarding letters. Weird and wonderful were the devices that would occasionally arrive at Eaton Square, and almost block up the hall and staircase to the intense indignation of an elderly butler.

Suggestions, some useful, some useless, arrived by nearly every post, and that hardy annual, a petition for Halfpenny Postage, arrived duly at the season of Postal Estimates and never failed to evoke H. H.'s condemnation.

A letter reached him posted in America with the simple address :

\section{Henniker Heaton,}

ENGLAND.

"I guess and calculate your Postmaster knows him."

The many charming anonymous letters of thanks that reached $H$. H. were a great pleasure to him, 
and Christmas time invariably brought forth a sheaf of good wishes from all parts of the world, signed variously: "A mother with sons abroad," "A working man and his friends," "An exile in Canada," etc. etc. If the writers should ever read this they will know how greatly $\mathrm{H}$. H. appreciated these letters of thanks from his unknown correspondents.

The following letter, which was printed in "The Times," brought forth the general opinion that it was more valuable as an argument for Penny Postage than all the statistics in the world:

ROSEBERY LODGE, Croydon Avenue, Croydon, To Mr Henniker Heaton,

SyDNEY, June I2, IgO5.

DEAR SIR,

It may seem a liberty to write to you, but I feel I must, and congratulate you on the Penny Postage to Australia. We all have much to thank you for. My niece brought me five letters by the mail a fortnight ago, saying, "Why, aunty, here are five letters, all for you, and from home." "Well," I said, "there is something wrong," but no, it was all right, all carried penny stamps, and at last we have the penny postage. Such a treat-five letters-one in three months was about the average.

You know a Scotchman loves his pennies.

I remain,

Yours respectfully,

MAGGIE COWPER.

The life of a Postal reformer is not an easy one, but it was undoubtedly brightened from time to time by little episodes that were not without humour.

A cable was sent by the late Rev. Henry Montague 
Villiers to his son in South America. Mr Villiers, having carefully inquired the price of each word, wrote rather a long message. The following day Mr Villiers received a letter from the G.P.O. demanding more than four times the amount, and stating that the clerk had made a mistake. A long correspondence ensued, but Mr Villiers consistently refused to pay. He very justly pointed out he would not have sent such a long message if he had known the real charge- the fault was that of the Post Office clerk, and the Post Office must bear the penalty. "If," wrote Mr Villiers, "I entered a restaurant and ordered vin ordinaire and the waiter brought me in error Château-Laffitte, and supposing I drank it, I should decline to pay for it."

A more tragic complaint was received from a lady who had sent a packet of valuable lace from Ireland. It arrived in a deplorable state, having been ruined by the breaking of a bottle of Condy's Fluid over it. The Post Office refused to give any compensation, as they do not hold themselves responsible for anything damaged in transit. "What would be thought," wrote H. H., " of a business firm like Pickford, or Carter, Paterson, who declined to give compensation? The public would not stand it for an instant."

In I89I, H. $\mathrm{H}$. compiled a long list showing the haphazard methods of the Telegraph Department in charging some words as one word, and others as two words-or even three. Here are some examples:

ONE WORD.

Upstairs. Can't, Won't, Don't. South Stainley. Hampton Court.
Two Words.

Down stairs.

Shan't.

South Hawley. Hampton Wick. 
ONE WORD.

Westgate-on-Sea.
THREE WORDS.

Sheerness-on-Sea.

So much ridicule was aroused by its publication that many of the anomalies were abolished. Undoubtedly the privilege of saying "Shan't" for one halfpenny was the most generally popular among the less obliging portion of the community.

For some years "H.M.S. _ " as part of the address was charged as one word, but "H.M.S. _ " in the body of the telegram was counted as three words. Perhaps it was partly the righting of this anomaly that Admiral Sir Albert Markham had in his mind when he wrote, "We in the Navy have special reasons for appreciating the great benefits that the untiring labours of Sir John have conferred."

A further list of anomalies was published in Igor:

ONE WORD.

St Pancras.

P.M.

Steamship.

St Peter.

New Brighton.

Twenty-five.

Needlemaker.
Two Words.

Charing Cross.

M.P.

S.s.

Peter St.

New Broughton.

Twenty five.

Cabinet maker.

Mr Austen Chamberlain wrote to $\mathrm{H}$. $\mathrm{H}$. on this subject :

Dear Henniker Heaton,

Your quarrel should be with the dictionary maker (two words) rather than with the Postmaster (one word). Thus "stove maker " and " boiler maker," e.g., are not recognized as words by the dictionary, 
whilst cabinet-maker, needlemaker, wig-maker, etc., are so recognized and printed.

It is a misfortune from the effects of which we daily suffer that the English language was a free and natural growth. Had it only been placed under the charge of the P.M.G. and swathed in red tape from infancy, we should have avoided all these gross anomalies which vex the soul of the careful student of the P.O. guide.

I hasten to add that there is no dictionary foundation for the difference between $£$ Io and Io/- (though, alas, a very important one in practice!), and I will try to meet your views on this point as well as upon the time of day.

Yours truly,

Austen Chamberlain.

Many complaints were received by $\mathrm{H}$. $\mathrm{H}$. from people who had suffered by reason of mistakes made by careless telegraph clerks. He was fond of telling the story of an announcement that appeared in the newspapers (by cable) to the effect that the wife of a certain Governor of Australia had given birth to twins, the eldest of which was a son. This announcement evoked unqualified astonishment among their Excellencies' friends. Explanations were demanded, and as a result it was found that the cable, "Governor twins first son," was a misreading of "Governor turns first sod," the message being concerned with the ceremonial opening of some public park.

King Edward VII. of blessed memory took a deep and encouraging interest in all H. H.'s schemes for reducing the cost of communication. On one occasion His Majesty landed at Dover and found H. H., who was returning from Carlsbad, on the quay. The 
2 I4 SIR JOHN HENNIKER HEATON

King shook hands with him and then, remembering with characteristic readiness the special interests of the Postal reformer, he waved his hand towards the channel, and said smilingly: "To think a letter costs twopence halfpenny to cross that." 


\section{CHAPTER XV}

THE FIGHT FOR PENNY POSTAGE WITH AUSTRALIA

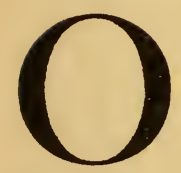

$\mathrm{N}$ his writing-table $\mathrm{H} . \mathrm{H}$. kept three envelopes. The first bore a sixpenny Australian stamp for a letter weighing less than a third of an ounce, addressed to him in England from Sydney, New South Wales, in April, I885; the second bore a penny stamp, addressed by H. H. in London to Lord Northcote, Governor-General of Australia, on the Ist April, I905; and the third bore a penny stamp, dated Ist May, IgII, posted in Melbourne, Victoria, and addressed to him in London, from the Hon. Josiah Thomas, Postmaster-General of the Australian Commonwealth.

The story of Penny Postage between England and Australia is of dramatic interest. It opens with the speech of that noble woman, Mrs Chisholm (" the Emigrants' Friend," whose name, if unfamiliar to English readers, is a saintly memory in Australian hearts), at a public meeting, in which she stated that the high postage prevented correspondence between emigrants and the old folks at home, and the suffering in consequence. Mrs Chisholm narrated the story of one poor old woman dying in England through having to refuse a letter on which she was unable to pay the postage. The letter contained $£ 25$.

On Australian stations far away in the bush there was nothing more touching than to see the emigrant 
son reading a letter from home. Many a time in his young life in the Colonies, H. H. was among a group gathered round the camp fire listening to the letters from Home read aloud. During his wanderings in Australia, he one day entered a Court House and was given a seat on the Bench. A young Irishman was charged with cheating and defrauding Her Britannic Majesty's Postmaster-General. Newspaper postage to England was one penny, but letters sixpence each. He wrote inside the newspaper: "My dear Mother, The long drought has ended in Australia, and I have got a situation at last on $\mathrm{Mr} \mathrm{B}$-'s station at a pound a week. Please God I will send you two pounds at the end of the month. Your affectionate son__" The newspaper was addressed to his mother in Limerick, Ireland. The postmaster discovered the message, and the man was arrested on $\mathrm{Mr} \mathrm{B}$-'s station for defrauding the revenue. He was sentenced to three weeks' imprisonment, and of course the loss of his billet followed.

These and other scenes, impressing themselves upon $\mathrm{H}$. H., built up his determination to secure cheap postage at all costs.

A Speech in favour of penny postage was made by Lord Rosebery at Paisley, in I885, in the course of which he said:

"Anybody who has to open the letter-bag of an estate, as I have to do very often, will notice the enormous number of letters with the Colonial stamp and postmark coming to the families living on the estate ; and it is perfectly futile for people to believe, whether Liberals or Conservatives, that with these letters passing and repassing between members of the same family in England and the Colonies, the 


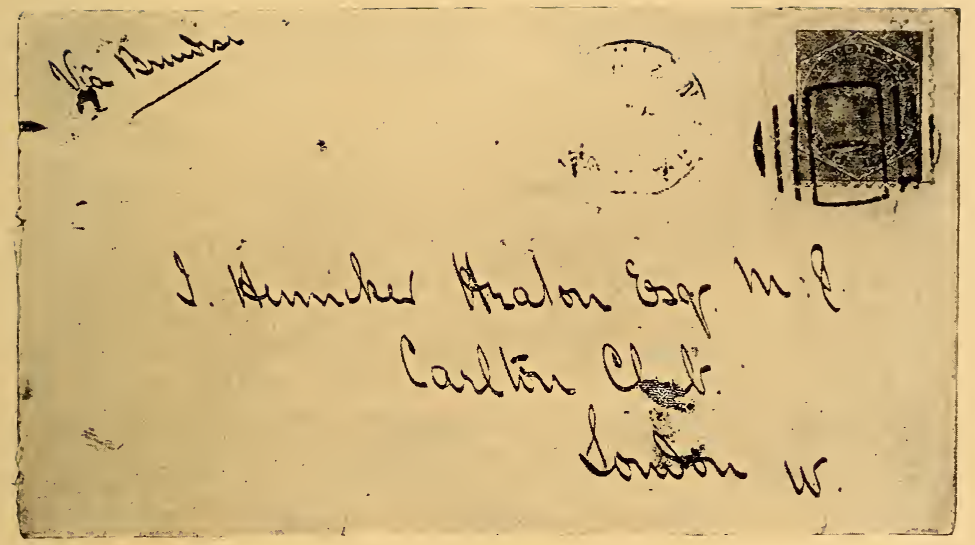

OLD LETTER FROM AUSTRAIIA BEARING SIXPENNY STAMP, I886

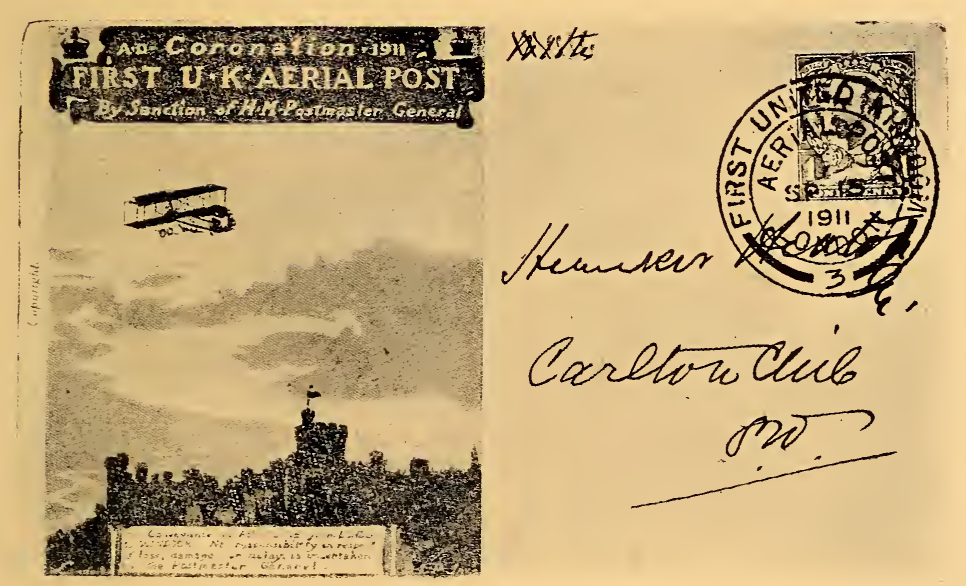

FIRST AERIAL LETTER POSTED IN ENGLAND, I9II 

members of the family who live in England could afford to be indifferent to the Colonies."

From his first entry into Parliament H. H. concerned himself with speaking, writing, and working in favour of cheaper communication. In I887, the First Colonial Conference was held in London, when H. H. proposed Imperial Penny Postage. It is hardly conceivable at this date that so little interest was taken in her Colonies by England thirty years ago : nor is it believable that an Agent-General should speak in the words used by Sir Saul Samuel on that occasion :

"There has never been any demand by the Colonies for any reduction of postage from $6 \mathrm{~d}$. to Id. If the Colonies do not complain, and if the Colonies do not want this reduction, is it to be given simply because some people in England agitate for it without any good reason?

"Further, we have to bear in mind that half the population of New South Wales consists of people born in the Colony, who have scarcely any reason for communicating at all with the mother country, and I believe that this will be found to apply to several of the other Colonies. A large number of people who go out from England very soon lose touch with the mother country, so far as correspondence goes, and it is not likely there would be any large increase in the number of letters."

It is hardly necessary to add that no action was taken as the outcome of the conference. More than ten years later, at a conference in 1898 , imperial penny postage was carried by seven votes to five, the five opponents being Victoria, Western Australia, South Australia, Queensland, and New Zealand.

This was a disappointment severely felt by H. H., 
but he was not discouraged. New Zealand, in Igoo, under the guidance of Sir Joseph Ward, was the first to give a lead by announcing not only Imperial but Universal Penny Postage. This news was communicated to H. H. in a letter dated I6th August, Igoo :

I have much pleasure in informing you that New Zealand will introduce Universal Penny Postage from the Ist January, Igor, as a befitting commemoration of the New Century and adding another link to the chain of Empire.

J. G. WARD, Postmaster-General.

Five years elapsed before $H$. $H$. received the following letter from Lord Stanley, Postmaster-General of England:

Dear Henniker Heaton,

I cannot allow the bald statement which will appear in Monday's papers to the effect that, so far as this country is concerned, a Penny Postage rate will come into force with Australia on Ist April to be the first announcement to you of the fulfilment of one of your postal dreams. You have worked for this reform with untiring energy, and I am glad to think that I am the first, though I shall certainly not be the last, to congratulate you. Credit to whom credit is due, and I should be the last to deny to you the credit of having to a great extent contributed to the success of negotiations which have terminated in a manner agreeable alike to you and to me. I trust now you will devote your attention to trying to induce the Commonwealth to lower, at the earliest possible moment, their tariff to a penny so that the Imperial Penny Postage between ourselves and the Colonies may be complete.

Yours sincerely,

STANLEY. ${ }^{1}$

1 Earl of Derby. 


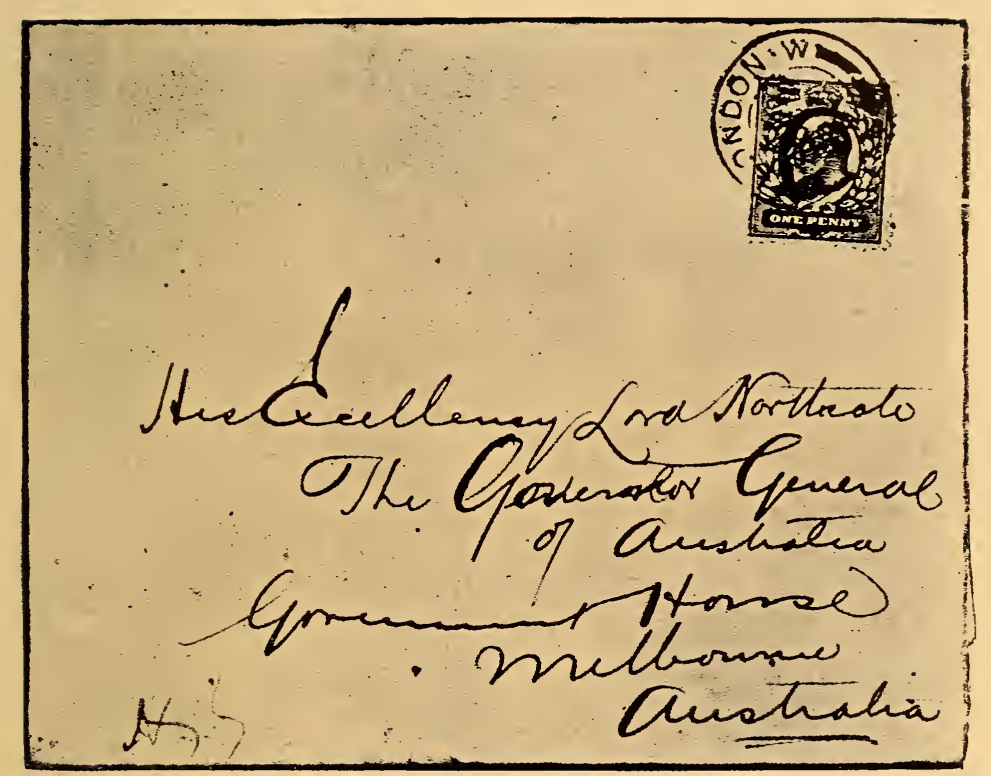

FIRST LETTER POSTED TO AUSTRALIA BY H.H. BEARING THE PENNY STAMP, I9O5

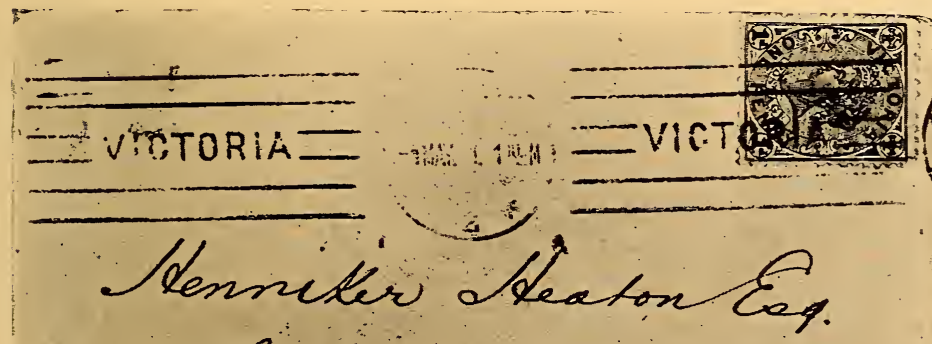
breton telic.

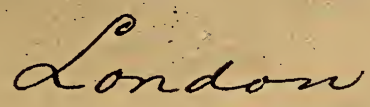

Hay. $\% 1911$

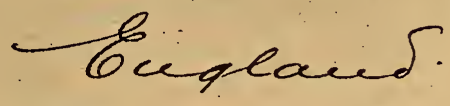

FIRST LETTER POSTED BY THE P.M.G. OF AUSTRALIA, THE HON. JOSIAH THOMAS, BEARING A PENNY STAMP, IO I 

H. H. replied as follows :

My dear Postmaster-General,

Only those who have grown grey in the pursuit of some high and cherished aim can understand the feelings with which I read your inclusion of Australia in the scope of Imperial Penny Postage. At last my reproach is removed, and an invidious exception, which went to my heart, is put an end to. No longer shall I be pained by reading such notices as "Penny Postage to all parts of the Empire, excepting Australia," or "Postage to all foreign countries and Australia, $2 \frac{1}{2} \mathrm{~d}$."

But my feelings are of small concern. It only remains for me, as a humble representative of public opinion in this matter, to tender you, as PostmasterGeneral, Mr Austen Chamberlain, as Chancellor of the Exchequer, and $\mathrm{Mr}$ Alfred Lyttelton, Colonial Secretary, and I ought to add the editor of the "Times," the sincere felicitations and gratitude of our countrymen on the happy completion of the Imperial Penny Postage scheme. It had already, like the sections of an unfinished railroad, produced considerable benefits. But so long as the island-continent stood aloof there was a kind of stigma attaching to it, which is now removed for ever. You have forged the last link in the intangible chain that binds the widely scattered fragments of the King's dominions into one solid mass. You have thrown the mantle of imperial unity over the shoulders of the Sovereign. You have struck the "Lost Chord" in the imperial symphony, and one grand, perfect chorus ascends over land and sea.

Let me mention that I have the strongest and most authoritative assurance that Australia will reciprocate your action at the earliest possible moment. I have never expressed impatience on the subject of her attitude, since I know that the adoption of the penny rate to England would involve the reduction 
of her inland rate to a penny, and a consequent annual loss of $£ 250,000$.

I ought not to conclude this letter of gratitude for a particular reform, great as it is, without expressing my sense of the value of numerous improvements effected in the postal and telegraphic system under the administration of yourself and your two predecessors, Mr Austen Chamberlain and Lord Londonderry.

I am, yours very faithfully,

J. Henniker Heaton.

In I906, Mr Austin Chapman, Postmaster-General of Australia, introduced a Bill to establish Penny Postage throughout the Commonwealth and overseas. It met with considerable opposition and was eventually shelved.

In I907, H. H. visited Australia, and had many interviews with leading citizens and members of Parliament, with regard to the rate of postage. He pointed out the absurd position Australia was in, and that Australia and China were the only countries not enjoying inland penny postage. An indignant Chinaman at once replied that China was enjoying penny postage, and that letters with less than a penny stamp franked letters from the uttermost parts of China and Japan.

Victory was completed in IgII, when the Hon. Josiah Thomas, P.M.G. of Australia, addressed the first letter under the penny postal rate to H. H. ; and the long and weary struggle was thus ended.

Twenty-six years of strenuous labour, twentysix years of unyielding perseverance in the face of indifference and opposition, resulted in the achievement of $\mathrm{H}$. H.'s deep-felt desire that he might live to see 


\section{THE FIGHT FOR PENNY POSTAGE 22I}

the country he loved enjoying the benefits of Penny Postage.

To Australia, the land of his adoption, H. H. owed much, and I think he felt that in some measure he was repaying his debt. 


\section{CHAPTER XVI}

\section{PENNY-A-WORD TELEGRAMS}

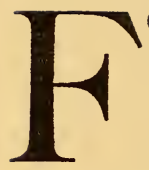

OR many years $H$. H. was engaged in endeavouring to secure the reduction of cable rates. In a letter addressed to the Postmaster-General, he wrote :

"At present the bulk of our trading negotiations are conducted in writing, just as they were between Assyria and Egypt thousands of years ago. There is a lamentable waste of time at every stage of the proceedings. We do business at a rate which might have been tolerable in patriarchal days, but which obviously leaves out of sight our slender span of lifeseventy years. My property is in Australia. It takes me three months to write to that country and get a reply to my letter. This is too much out of my span of seventy years. Yet the human race for two generations has been in possession of means of instantaneous communication of thought, so perfect, so unerring, so docile, and so plentifully found in Nature that it would tax angelic intelligence to improve upon it. This means is, for all but the most urgent concerns, as utterly ignored and neglected as if we were living in the days of the Pharaohs. Even when it is employed, each country sets a new tax on the passing telegram, as it would upon luxuries or dangerous commodities. The flash of the message instantly passes over the face of Europe from one end to the other; yet it has to pay toll more than once on its way to the various foreign Governments. It seems to me it would be as reasonable to tax a sunbeam." 
In 1907 , an article by H. H. in the "Arena," entitled "How to Smash the Cable Ring," first aroused public interest. The next year this was followed up by further revelations in "The Financial Review of Reviews," which created a remarkable sensation. Thus encouraged, $H$. $H$. issued a pamphlet advocating the establishment of universal penny-a-word telegrams, which he submitted by way of referendum to the judgment of representative members of the thinking classes.

The overwhelming consensus of opinion in favour of penny-a-word telegrams led to a great meeting being held by the Royal Colonial Institute to consider the practicability of penny-a-word telegrams throughout the Empire.

The late Lord Jersey presided, and powerful speeches were made by Mr Marconi, the Postmaster-General of Canada, the Hon. R. Lemieux, Lord Strathcona, Sir Charles Bruce, and others.

In the course of his speech H. H. said :

"Twenty-one years have passed away since I stood on this platform before a distinguished representative and imperial assembly to advocate imperial penny postage and cheap cablegrams. On that night, in the year of the first Jubilee, I first advanced the theory that a cheap telegraphic system for the Empire was a commercial possibility, and that it would do much to knit together our scattered Empire and link up its many peoples.

"I need not bring back to your minds the fierce resistance this project encountered. It was 'unheard of,' ' monstrous,' and ' the wild phantasy of a dreamer.' I was denounced for this notion of cheap cabling in the language of the Old Bailey. The proposals I placed before you were viewed with abhorrence by 
the cable companies. They could not see the practicability of my ideas. But in the course of the rolling years these so-called visionary projects have already come appreciably near to realization. That which I advocated in the closing years of the last century was a mild reform compared with what presents itself within a wider horizon in this twentieth century. Today what we want is a universal penny-a-word rate, and he would be a bold man indeed who would deny the certain realization of our hopes.

"Let me go back for a moment to that stormy night in I887, which is full of suggestiveness to all those who have stood with me in the forefront of this battle waged against reluctant officialism, which, vowing that it will never surrender, always ends by giving way. On that occasion I advocated the construction of a cable from the Cape of Good Hope to Australia. The Eastern Telegraph Company, in the person of one whom even his opponents would call our dear old friend, Sir James Anderson, deemed the notion impossible. Sir James Anderson said: "There is some talk of taking a cable all the way from Australia to Mauritius across the route of the trade winds to the Cape. There is not even a sandbank on which to catch fish. There is not a port to which a cruiser or a cable-ship can go to replenish their supply of coal, which they are certain to require to do. There are no ships going there. There is no trade, and nobody wants to go there.'

"This was very plain and to the point. And now what has occurred? On January I, Igor-only fourteen years afterwards-the Eastern Telegraph Company finished the construction, at their own expense, of this very cable which they had denounced me for advocating. Sandbank or no sandbank, fish or no fish, observant men knew it was to come. I must quote Sir James Anderson's speech that night once more: "Take the cable from Canada down to 
Fiji and New Caledonia to Australia. I do not believe in it a bit, and I hope that no one with whom I have influence will ever put a penny of money into it, but leave it to those gentlemen who do not know any better.'

"That cable is also laid-the cable from Canade via Fiji to Australia. To Sir Sandford Fleming, that veteran Canadian whose patriotic work will for ever be remembered, the credit of this work is due.

"The chief obstacle which is before us in the fight for carrying out our policy is in the political frontiers. Our object, therefore, should be to abolish political frontiers, so far as telegrams are concerned, in our communications with every part of the earth. In this matter 'political' frontiers, by arrangements with foreign Governments, ought not to be taken into consideration at all. Between man and man these political frontiers should not exist. As a matter of fact to the travelled individual who has friends all over the world they do not exist, except on paper.

"At this point it may be observed that if we cannot get over this difficulty I place my hopes on my friend Marconi. He entirely ignored political frontiers when I received from him at Port Said, on board the " Renown," a wireless message which must have passed over all the political frontiers of France and Spain and the Alps before it reached Port Said in Egypt."

No time was lost in calling a meeting at the Mansion House, presided over by the Lord Mayor, Sir J. C. Bell, and attended by a number of highly important and influential City merchants. Among others present were men of such world-wide interests as the Duke of Argyll, Lord Milner, Lord Blyth, Lord Strathcona, Sir Owen Phillips, Sir William Holland, Sir Edward Sassoon, Sir Albert Spicer, and many others.

The speeches delivered by Captain Muirhead Collins 
and by the Hon. R. Lemieux were of such a character as to render it certain that the Colonies were fully determined to secure the benefits which cheap telegraphy would confer.

A resolution was proposed by the Duke of Argyll and seconded by Lord Milner :

"That this meeting, convinced of the desirability and necessity to manifold imperial interests of a system of low priced, easy, uniform means of telegraph connexion within the Empire, pledges itself to support the efforts of the Cable Committee of Members of Parliament with that supreme object in view.'

If $\mathrm{H} . \mathrm{H}$. hoped that an immediate reduction of all cable rates would follow, such hopes were doomed to disappointment. Very carefully, very slowly, minor concessions were granted, such as a halfpennya-word reduction in rates for telegrams to thirteen countries in the European system.

An impetus was given to the movement for cheap cabling by a highly instructive paper read before the Royal Colonial Institute, by $\mathrm{Mr}$ Charles Bright, F.R.S.E., M.Inst.C.E., M.I.E.E. "It has always seemed to me," he said, "that a great advance would be made in our inter-imperial communications if an all-round imperial cable tariff-say, of Is., 9d., or even 6d.--could be put into operation."

A pronouncement from such an authority carried considerable weight among even the most sceptical. Mr Bright's name will always be associated with every victorious step in the direction of cheapening imperial communications.

The year I909 was memorable for the first Imperial Press Conference held in London. The Conference 
was primarily the conception of Mr Harry Brittain while travelling in Canada. After enlisting the sympathy of the Governor-General, he returned to England and secured the co-operation of all the great newspaper proprietors and editors, including Lord Burnham (President), the Honble. Harry Lawson, Lord Northcliffe, Mr Arthur Pearson, and Mr J. A. Spender. Discussions were held on the Defence, Commerce and Unity of the Empire, and speeches were made by leading statesmen of every country represented.

On the subject of imperial communication $\mathrm{H} . \mathrm{H}$. was invited by the Secretary of State, Mr Harcourt, to lay his views before the Conference and to furnish the members with the necessary number of his pamphlets on cable communication.

One immediate result of the Imperial Press Conference was to reduce the Press Cable Rates to almost every part of the Empire by twenty-five per cent.

The further result of this reduction was that more news was obtained at the same price and-what was more important-it succeeded in creating a demand for more news still.

No longer need Canada complain :

"We are kept fairly well posted up upon the happenings in Great Britain though nine-tenths of this news comes to us by United States channels, but what do we really know about what is going on elsewhere in the Empire?

"During the South African War we were posted about every clash between outposts: but with the return of peace South Africa ceased to be regarded as a source of news and in the last seven years we have not received, all told, as much cable news from that part of the Empire as we did in a single week during the war." 
With the advent of $\mathrm{Mr}$ Herbert Samuel to the Post Office the "Deferred Message" System was introduced, by which plain language telegrams to British oversea Dominions and the United States were reduced by one-half, subject to deferment of not more than twenty-four hours. Other facilities were granted for sending long messages known as "Weekend letters" at a fifth and a quarter the usual rate. From time to time, other reductions have followed and, although the dream of penny-a-word telegram is still unrealized, the day may not be far distant when we shall speak as easily to Australia and New Zealand as we do to Ireland.

H. H.'s faith in Wireless Telegraphy never wavered from the time of his first coming into contact with Marconi and his invention. His heart was set upon bringing the various units of this great Empire into closer contact with each other, and he regarded Wireless Telegraphy as the means which would, combined with cheapened and accelerated postal communications, do more to effect that end than any other possible human agency.

H. H. was a firm believer in the future of etherwave transmission from the point of view of the interests of this country and the world at large. $\mathrm{He}$ looked with admiration and approval at the work which Marconi had already effected, and placed unquenchable faith in that which he was destined yet to achieve. Whenever a new invention or development of a former one had reached a stage suitable for investigation, $H$. $H$. was always one of the first to be consulted and his sympathetic attention never failed.

His interest was enlisted in an invention of Marconi's 
for use in warfare, and in I902 Field-Marshal Sir John French wrote as follows :

My dear Mr Henniker Heaton,

Many thanks for yours of the 2oth.

I am obliged to get special permission from the W.O. to try any new inventions here. This I hope to obtain shortly and we will then proceed.

I shall be very glad if you will kindly come to stay with me when the trials are going on.

Yours very sincerely,

J. D. P. FRENCH.

The close of the great European warfare now in full tide is likely to witness the fulfilment of $H$. H.'s prophecy: "The world watches Marconi as one of the gifted leaders born for our time. His system is a powerful factor in our crusade of cheap imperial communications."

It is interesting to recall that H. H.'s last public utterance in the City of London was a plea for the establishment of penny-a-word telegrams.

The Right Honourable Sir Vezey Strong, K.C.V.O., wrote as follows :

\section{Dear Madam,}

I enclose you a brief notice of the Banquet given by the Worshipful Company of Plumbers on the 2oth December, I9I2, at which your father, Sir John Henniker Heaton, was an honoured guest, and at which, as Master of the Company, it was my privilege to preside.

I think you will find that the last public pronouncement by your father, of his hopes and aspirations for the further extension of the beneficent work to which he devoted so much of his life, was made on this 
occasion, and it seems to me that a Biography of Sir Henniker Heaton could not end on a more appropriate or inspiring note than the quotation of his own words, uttered at the close of his public career.

The Banquet of the Plumbers' Company was, I believe, the last occasion on which he spoke in the City of London. I use the word "the City" in its strict sense, for, as you will probably know, the City is that portion of London governed by the Lord Mayor and Corporation, having as its centre the Guildhall and the Mansion House, and as its Western Boundary the place where Temple Bar formerly stood, now marked by the Griffin opposite to the Law Courts in the Strand. The guests included the Lord Mayor, Sheriffs, representatives of State Departments, the Colonies and oversea Dominions, Mayors and principal officers of Metropolitan and Provincial Boroughs, the Presidents and Members of Scientific and learned Societies, Guilds, and other bodies.

It was an occasion so important and so significant that its full significance was perhaps hardly realized at the time. It is only in looking back upon such moments that they come into their proper perspective.

"I shall not regard my work as completed," said your father, "until time and space have been annihilated, and the scattered coasts of the Empire have been so united that we can speak to the people of New Zealand as easily as I am speaking to this company."

It was his farewell message to the Empire which he so greatly loved, spoken from the very centre of that Empire; and he was at that moment surrounded by men who can powerfully help to the fulfilment of his dream. The High Commissioner for New Zealand was sitting by his side.

It was your father's inspiration to " Carry On!"

Those who were present on that occasion will read again in your book the words which they heard from 
your father's lips. And thousands more in all parts of the world will read them and be moved by them to fresh exertions for the achievement of his dream, and of more than even he ever dreamed.

I am, dear Madam, Yours very sincerely,

T. VEZEY STRONG. 


\section{CHAPTER XVII}

\section{AN IDEAL POST OFFICE}

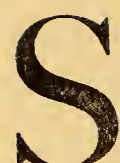

IXTY-TWO reforms-one for each year of his life-were drawn up by $\mathrm{H}$. $\mathrm{H}$. on his retirement from Parliament, I9IO, and presented to the Postmaster-General ${ }^{1}$ - with the following letter :

My dear Postmaster-General,

You will have observed the tendency of men who have taken part in political affairs to set forthI will not say bequeath-on their retirement a scheme of general improvement for the benefit of their fellows.

Although wanting the profound sagacity and dazzling imagination of the great Utopians of past years, I would yet crave permission to enumerate certain reforms in the great postal department over which you preside, which might render it still more efficient. None knows better than a close student of all the post offices of the countries of the world, how splendid is our record of achievement in the British Post Office. Much courage is required to point out any remaining defects or failings. But we all know our truest friend is he who tells us of our faults. From this point of view I am the best friend the Post Office ever had.

This is not the first time I have ventured on a summing-up of postal grievances. Each of your predecessors during the past quarter of a century has received such a list at my hands. Many of these demands-nearly one hundred-have been conceded,

\footnotetext{
1 The Right Honble. Herbert Samuel.
} 


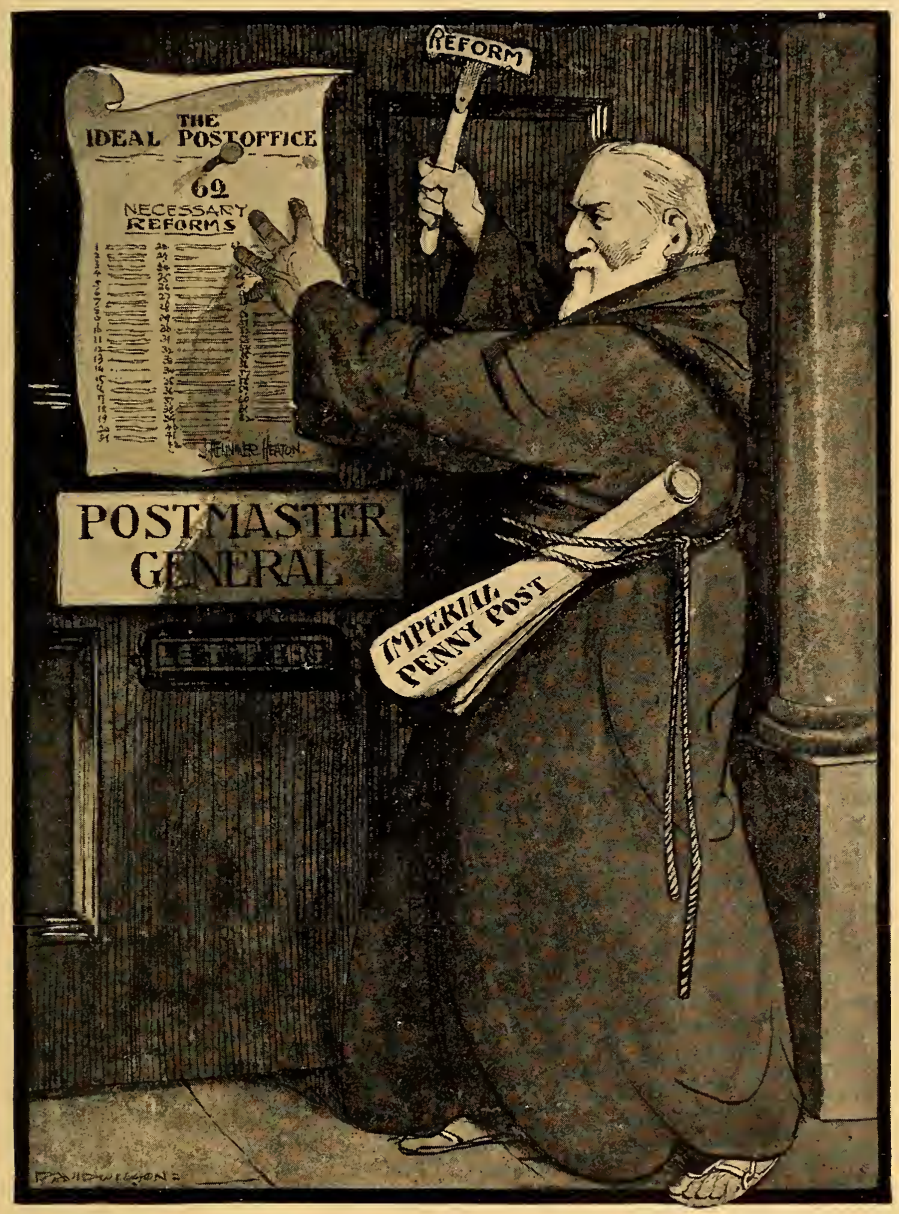

THE MARTIN LUTHER OF THE POST OFFICE

By permission of the proprietors of "The Graphic" 

including such substantial boons as imperial penny postage, and penny postage to the whole of the English-speaking countries of the world.

There remain the 62 given herewith-one, by an accidental correspondence, for every year of my life. Many of these you may meet at a little greater expenditure than that of the ink used for your signature. All represent real and urgent public needs. Some of them I drew up as a young and hopeful reformer. They still utter the wishes of the public-an appealing note of truth, like the old gramophone records into which Browning breathed poetry and Patti music. They stand as a Pygmalion's gallery of statues waiting for life to be breathed into them. Need I say by whom ?

Of one thing all who know you will be assuredthat not one reform will be refused or delayed without your personal and unbiased investigation of the question involved, or because the interest of humble toilers only are at stake.

In conclusion, permit me to express a hope that you may adopt the suggestions and reforms given below ; in other words, so signalize your term of office by improving the communications of the people by post, telegraph, and telephone, that at its termination you will need no other memorial than the record of these achievements.

I am, your obedient servant, J. Henniker Heaton.

\section{The Ideal Post Office}

I. Universal penny postage.

2. An Imperial Postmaster-General.

3. International Conference between PostmastersGeneral in reference to telegraphic and telephonic communications. 
4. Telegraph tariff to any part of Europe to be one penny per word.

5. Halfpenny post cards to all parts of the world.

6. Rearrangement of time-tables for mails to and from Australia and India, whereby sufficient time be allowed for replies to be written.

7. Telephone charges to the Continent to be substantially reduced.

8. Parcel post to foreign countries and the Empire generally.

9. Telegraphy money order extended to all parts of the civilized world.

Io. The cables owned by British companies to be acquired (and all gaps bridged) by the British, Indian, and Colonial Governments, and worked at the lowest remunerative rates.

II. Telegrams to all parts of the British Empire to cost one penny per word, with a minimum total charge of one shilling.

I2. A cheap agricultural parcel post with special provision, by motor-car or otherwise, for rapid collection throughout Great Britain and Ireland.

I3. Introduction of the cash on delivery system.

r4. Minimum charges for samples to be reduced to one halfpenny.

I5. Post cards to be sold at their face value.

16. Quality of post cards to be improved.

I7. Permission given to stick a newspaper paragraph on a card.

r8. All charges for printing halfpenny stamp on private post cards to be abolished.

Ig. All anomalies and contradictory regulations to be put right.

20. An imperial exchange or clearing-house for postal orders to be arranged.

2I. No confiscation of reply-telegrams if unused for any length of time.

22. Stamps to be sold on Sundays at all telegraph 
offices, railway stations, and the chief provincial post offices that are open for general business.

23. Mandat-carte system to be introduced for sums up to $f_{\mathrm{r}}$.

24. The charge for registration of letters and all postal articles to be reduced to one penny.

25. The fine for insufficient postage not to exceed one halfpenny for inland and one penny for foreign letters.

26. Three classes of postmen for expediting delivery, (I) letters and post cards, (2) newspapers,

(3) parcels.

27. Tube conveyance of mails in cities.

28. Letter boxes to be provided on all through trains.

29. England is the only country not named on its own postage stamps. This to be remedied.

30. An international postage stamp to be brought into use-or an exchange of stamps at the various post offices of the world might be arranged as bankers exchange their cheques.

3I. The sender of a letter to have the right to recall it after posting.

32. Postmarks to be made clear and legible.

33. Letters containing lottery tickets and advertisements to be destroyed.

34. Full compensation to be given for neglect, default, or larceny by officials.

35. Improved pillar-boxes for the safe-guarding of letters.

36. Charges for redirection of telegrams to be abolished.

37. The name of each place, etc., in the United Kingdom to be charged in telegrams as one word.

38. Name and address on telegrams free, or twenty words for sixpence.

39. Compensation to be awarded for errors in telegrams through carelessness on part of the post office employé. 
40. Telephone calls to all parts of the Kingdom to be reduced.

4I. Magazine post at the rate of eight ounces for one penny.

42. All bona fide periodicals issued for sale to be registered and transmitted at newspaper rates.

43. Sailors and soldiers serving abroad to have their letters sent postage free.

\section{4 .}

Halfpenny Post

The following notice on the Parliamentary paper explains itself :- $\mathrm{Mr}$ Henniker Heaton: Halfpenny Post.

To call attention to the halfpenny post regulations of the British Post Office, and to the fact that tens of thousands of British subjects are fined annually for breaches of these regulations through being unable to define what is halfpenny matter and what is in the nature of a letter; and to move: that, inasmuch as the Postal Guide contains more than two pages of definitions, and that there are only two persons in the Post Office who know what can and what cannot be sent by the halfpenny post, and that these two disagree, steps be taken forthwith to revise and simplify the definitions and regulations.

\section{Reply Coupons}

All coupons for reply stamps cost $3 \mathrm{~d}$. - that is, $2 \frac{1}{2} \mathrm{~d}$. for the stamp and $\frac{1}{2} \mathrm{~d}$. commission. Now that postage is reduced to India, to all the Colonies of the British Empire, and to the United States of America and Egypt, to Id., coupons for reply stamps should not cost more than $I \frac{1}{2} \mathrm{~d}$. each to these countries.

46. The Post Office Savings Bank to accept pence.

47. The system of mail subsidies to be placed on a business footing. 
48. All business expenditure for sites and buildings to be carried to a capital account, and spread over several years, instead of being paid out of current revenue.

49. The surplus of the Post Office over and above three millions sterling to be devoted to cheapening, extending, and facilitating the postal and telegraphic services of Great Britain and Ireland.

50. A Government printing office to be established.

5I. The insurance department of the Post Office to be placed under the control of an experienced manager.

52. The architecture of post offices to be improved. Office.

53. Lodgers' letters to be re-addressed by the Post

54. A letter service de luxe to be established. I would invite designs for a handsome express stamp, value $3 \mathrm{~d}$. This express stamp would insure delivery, (I) of any special letter of great importance, (2) of a letter on Sundays throughout London, and (3) it would also insure a letter catching the Continental or latecountry post. It would be delivered by a special bicycle messenger.

\section{The Reposting of Newspapers}

Considering the importance of publishing Empire news throughout Great Britain and Ireland, I hope you will consent to the registration in this country, at the present rate for British newspapers, of all newspapers published in Canada, Australia, New Zealand, Africa, the West Indies, and all the other colonies and dependencies of the British Empire, so as to enable them to be reposted at a moderate postage rate to friends in this country. for.

56. "Baggage smashing" to be stopped or paid

57. LonDon should be made one district in regard to the redirection of parcels. 
May I venture to recommend that you should reconstitute London one postal district for the redirection of parcels? A parcel redirected from the House of Commons to Eaton Square is sent free; but a similar parcel sent from the House to the Grand Hotel, Charing Cross (one quarter the distance) is subjected to a fine of ro $\frac{1}{2} \mathrm{~d}$. for redirection.

\section{The Telegraph Department Deficit}

Your telegraphic deficit of one million sterling per annum is not very creditable to your department. It is not paralleled in any other civilized country in the world. Some time ago, I found that every inland telegram cost you a shilling, while the average value or receipt was $7 \frac{1}{2} \mathrm{~d}$. for each telegram.

59. A new post and telegraph office to be erected at Charing Cross.

6o. A clear and Intelligible "Post Office Guide" in legible print to be prepared.

It is suggested that the "Guide" should be revised in the interests of the public, and that the regulations should be at least grammatical, always clear, and occasionally generous.

\section{I. Automatic Stamping Machines, etc.}

As we are dealing with ideals, let me breathe a sigh for the speedy advent of a penny in the slot letterstamping machine, which will one day be incorporated with every pillar-box.

This will do away with the nauseous formality of licking adhesive stamps, and many journeys to purchase them, and it will be a step towards the riper ideal of the penny telegram. 
62.

StAMPING NeWSPAPERS

In all the great newspaper offices of London, Liverpool, Manchester, Dublin, Belfast, Edinburgh, Glasgow, etc., and at the principal newspaper agencies, you should arrange with the principals to save expense and delay by posting the newspapers without affixing stamps, and in some cases even postmarking. 


\section{CHAPTER XVIII}

\section{RECOGNITION}

"T IFE has been very good to me," H. H. was sometimes heard to say, and he spoke humbly as one undeserving of much reward. In a world where so many lives are embittered by disappointment, so much merit unrecognized, it was always with a sense of heartfelt gratitude that $\mathrm{H}$. $\mathrm{H}$. received the just reward of his labours.

I think the honour he prized beyond all things was the bestowal upon him of the Freedom of the City of London, in I899. It is an honour few may claim. Titles may be bought, patronage may secure privileges, but merit alone can win a place upon "London's Roll of Honour." The casket containing the scroll of Freedom was of solid gold, ornamented with enamelled panels representing the old fashioned mail coach and mail train and views of an old-type sailing ship and modern steamer. The quaint testimony of the "compurgators" was read before the Lord Mayor, declaring that " $\mathrm{Mr}$ J. Henniker Heaton, M.P., is a man of good name and fame, that he does not desire the Freedom of the City whereby to defraud the Queen, or this City of any of its rights and customs or advantages, but will pay scot and bear his lot, and so they all say."

The Chamberlain, Sir Richmond Cotton, in moving the address said: 
"Mr Henniker Heaton-You have heard from the Town Clerk the Resolution in which the Corporation of the City of London unanimously decided to enrol your name in the list of its Honorary Freemen.

"It becomes my pleasant duty, as Chamberlain of London, in the name of the Court, to offer you congratulations on those public services which have led the City to record you on what has been not inaptly called 'London's Roll of Fame,' which includes Kings, Princes, Statesmen, Patriots, Warriors, Explorers, Discoverers and Philanthropists. It is as a Philanthropist that we are privileged to greet and welcome you to-day.

"It will be interesting to you to be reminded that twenty years ago an exactly similar honour was bestowed by the Corporation on that great postal reformer Sir Rowland Hill, in acknowledgment of the social and commercial benefits the country had derived from the adoption in 1840 of his system of Uniform Penny Postage in the United Kingdom.

"And now, Mr Henniker Heaton, I have the honour and pleasure, in the name of the Lord Mayor, Aldermen, Sheriffs, and Common Councilmen of the City of London, whose action to-day will, I feel sure, be warmly endorsed by all classes of the community, not only here, but in India and the Colonies, to offer you the right hand of fellowship, as a Citizen of this great City, and to ask your acceptance of this gold casket containing the scroll of your Freedom, which may remind you, and those who may follow you, of the respect and esteem entertained for you by this ancient Corporation for your distinguished public services as a Philanthropist and a Reformer."

The Freedom of the City of Canterbury was conferred upon $\mathrm{H}$. H., and thus he became a Freeman of the Capital of the Empire, and also a Freeman of the ecclesiastical capital of the Empire. 
The presentation of a testimonial from the Heads of Australian Banks in London had a double significance. It not only expressed their appreciation of his Empire work but it set the seal of approval upon its financial aspect. Bankers are proverbially longheaded, and when they are pleased to approve a scheme it is high time for all talk of "visionaries and dreamers" to cease.

H. H. was a Fellow of the Royal Colonial Institute, a Fellow of King's College, London, and a Fellow of the Royal Society of Literature. Some years before his death his name was put forward as a candidate for the Nobel Peace Prize, and had he lived his friends hoped to see this bestowed upon him, supported as it was by the greatest names in England.

Throughout his political life, his efforts were encouraged by words of appreciation from the highest to the poorest in the land. $\mathrm{He}$ was honoured on more than one occasion by a letter of thanks from Queen Victoria, King Edward, and Queen Alexandra. At the other end of the scale he appreciated the pious wish of an unknown admirer who wrote, "A Birmingham navvy desires to congratulate you on your success-Penny Postage. I should like to have the job to excavate for foundation of your monument."

During H. H.'s visit to Australia in I9I2 his services were recognized by the bestowal of a baronetcy by the King. A public welcome awaited him on his return to London, under the auspices of the British Empire League. Lord Blyth, with Lord Curzon, arranged the form of the welcome, and the presentation of an illuminated album, containing over a thousand signatures, and the appreciations of distinguished and 
representative men not only of all parts of the Empire, but also of many foreign countries.

The Presentation took place on Tuesday, June II, I9I2, and the following account appeared the next day :

The City of London has a manner and a splendour all its own, and both of these last night were at the service of Sir Henniker Heaton. The City does not receive its chosen heroes as its neighbour Paris welcomed General Boulanger.

The atmosphere of the Masque has never been the atmosphere of London's Civic welcomes. We do not throw confetti and shake out fairy-lamps and spangles on to the dark mantle of our midnight greetings. We prefer to take our chosen heroes quietly, as befits a quiet and sober folk, into that great oldworld "parlour" of our City, the Guildhall, and, sitting together in the homely fashion of people who have earned a rightful repose through work and labour, talk to our guest of honour of his triumphs and his achievements, wish him the brightest of futures, toast him among ourselves, and depart on our several ways with a fervent hope that the serenest stars will illuminate the evening of his days.

It was so with Sir Henniker Heaton last night. He was welcomed at the Guildhall by the Lord Mayor, Lord Curzon, Lord Blyth, and at least a thousand members of the executive and general committees formed at the invitation of the Duke of Devonshire to do honour to a great benefactor of humanity on the occasion of his return to England.

The historic wealth of our old city hall, the greyness of its walls, its breathing sense of slowly established traditions and history lent an atmosphere of stateliness and dignity to the proceedings which brought out the cause rather than the brilliance of the assemblage. 


\section{LORd Curzon on "LOve Knots"}

Most of us know to-day something about the remarkable symposium of expressions of appreciation of Sir Henniker Heaton's work on behalf of universal and imperial penny postage, something about the character of those appreciations and the representative men of all classes who have contributed to them. It was fitting that the symposium preserved in an illuminated album should have been made the crux of the evening's ceremony, and it was fitting that so brilliant and so polished an orator of Empire as Lord Curzon should have consented to make the speech of presentation.

A commanding figure on the draped dais raised in the centre of the great hall, with the clustered light and the old civic banners above his head, Lord Curzon enraptured the brilliant assembly gathered around him in a speech that possessed the polish of fine oratory and the mellowing touch of human feeling. When he referred to the amount of happiness Sir Henniker had brought into the world, the mothers whom he had united to emigrant sons, and the "love knots" he had tied, by the wonder of the penny stamp, our eyes turned involuntarily to the white-haired figure of Sir Henniker himself, and it was easy to see that, as he listened with all the pride of a man who has served time well-and who has lived to be recognized by his generation-he was touched with profound emotion.

And in his reply he spoke at times with a pardonable emotion, but always with dignity. It was the speech of a man looking back upon the chronicle of his days, and seeing that it had been written in letters that were well and fair. It was, moreover, a speech of great natural modesty. It drew us closer to Sir Henniker, and, after all, it is not very difficult to be drawn close to a man who has drawn half the world together. 


\section{"Merely a Postman"}

Sir Henniker Heaton said: "One thought saves me from being utterly abashed at this great representative gathering. It is the belief that I am merely a letter-carrier or postman, and from the kindly light in your eyes I see you are going to 'tip the postman' for bringing you letters of love from the millions of our brothers and cousins beyond the seas, who have now free, untaxed, unimpeded postal communication with the Mother Country.

"If the British Government will spend as much money in electrical communications as she did in mail subsidies seventy years ago we can have pennya-word cables to our most distant possessions.

"Let us take warning by the Tower of Babel, and teach the workers in our great fabric of Empire to converse freely-it cannot be too freely; and electricity is the heaven-sent agency which has been placed at our disposal.

"Let us adopt the formula, "Twelve words for a shilling.' With this simple incantation we can transform the Empire, quadruple its resources, multiply its strength, fill the National Exchequer, and make the face of the poor toiler radiant with happiness."

During the evening the following letter was read from Mr Herbert Samuel :

\section{Letter from the Postmaster-General}

DEAR LORD CURzON,-I greatly regret that, being confined to my room by doctor's orders, I cannot be present to-night at the gathering which will be held under the presidency of the Lord Mayor of London, to pay fitting recognition to Sir Henniker Heaton for his lifelong service to postal reform.

As the latest of the long line of Postmasters-General whom he has harassed so efficiently and with so much 
advantage to them and to the public, I should like to pay my tribute of thanks for his many suggestions, large and small, possible and impossible. Why should not the ox be grateful to the goad if it causes him the better to plough the field?

On the occasion of Sir John's 62nd birthday he was good enough to send me a list of 62 desirable postal reforms. Several of them have since been carried into effect, with a few more which had escaped even his searching eye. But I am quite convinced that he will soon fill the gaps again, and we all hope to read on later birthday anniversaries fresh lists of seventy and of eighty changes which a truly progressive Post Office would hasten to adopt for the common weal.

In the hope that till those days, and later, he may enjoy his new honours, I ask leave for my Department and myself to join in the national manifestation of gratitude which is rightly being paid to a great and tireless reformer.

Believe me,

Yours sincerely,

\section{Herbert Samuel.}

The successful organization was due to the untiring energies of Lord Blyth, who devoted himself whole-heartedly to the task of giving his old friend the best and warmest of welcomes in the best and warmest of ways. He was ably seconded by $\mathrm{Mr}$ Freeman Murray, who undertook the duties of Honorary Secretary for his friend $\mathrm{H}$. $\mathrm{H}$.

MY DEAR LORD Blyth,

Carlton Club, July 20 th, IgI2.

The last act of the great drama is finished and it remains for me to try to say to you that I feel it utterly impossible to express my gratitude. I did 
not think it possible for any man to work as you have done, so generously, so unceasingly for your friend, night and day for months, without reward in order to do me honour. It is true that I suffered a good deal from official classes backed up by powerful politicians who made extraordinary efforts to prevent our carrying great reforms. It was a great and longcontinued struggle, lasting over a quarter of a century. Your share in it, especially the Anglo-American post, is one of the most interesting chapters. However, I am, through your noble and unselfish efforts, amply rewarded, and in the years left me I trust I shall have an opportunity of showing my deep gratitude, and I hope you will call upon me in any trouble. We have learnt not to flatter each other, but like trusty warriors to defend each other. I pray for health and peace for you and yours in the days and hours to come.

Your attached friend,

J. Henniker Heaton. 


\section{CHAPTER XIX}

\section{REQUIESCAT IN PACE}

T $\mathrm{N}$ the beautiful city of Geneva, lies at peace the great Postal Reformer, Sir John Henniker Heaton.

1. His restless spirit has found rest at last, and he who in time of peace fought so valiantly the battles of his fellow-men may now sleep undisturbed by sound of cannon and clash of arms.

"To make communication as easy as speech and as free as air" was his life's ideal, and yet when he lay within the shadow of death communication with his own family was denied him. Telegraph lines that should have brought him loving messages were blocked with news of bloodshed and battle; trains that should have carried his anxious family swiftly towards him were filled with troops hurrying to the Front.

Sir John was among the English visitors in Carlsbad when War was declared. On September 2nd, I9I4, with a party of other non-combatants, he left Carlsbad on the return journey to England which, alas, he was destined never to reach.

\section{AMERICAN CONSULATE}

Carlsbad, Bohemia, Austria

TO Whom it MAY CoNCERN :

I, George Platt Waller, Jr., American Vice and Deputy Consul at Carlsbad, do hereby certify that 


\section{H.LERRICAN CONSUIATE \\ ReARISBAD, BOHEMIA AUSTRIA. on}

TO WHOU IT MAY CONCERI :

I, George Platt Walle: Jr, Smerican Vice and Deputy Consul at Karlsbed, do hereby certify that the bearer of this document Sir Herniker Heaton,Baronet, former Postmaster General of Engladd, and Lember of Parliament for many years is a British Subject, of great distinctiorand worldwide fame. As under the present distressing circumstances, the American Consulate has been requested to extend its good offices to the British Subjects, II hereby bespeak for Sir Henniker Heaton, any and all aid that it may be possible to extend under your jurisdiction in expediting his peaceful and speedy progress on his lavful occasions, both as a British Subject and as a Benefactor of the Human Race.

Scorge Platu Wacen Is American Vice \& Deputy Consul.

Given this 3 lst day of August 1914.

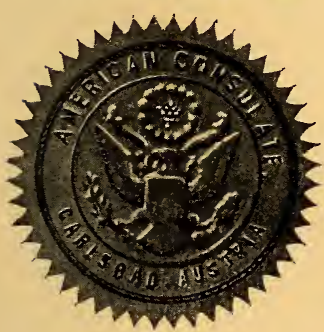



the bearer of this document Sir Henniker Heaton, Baronet, former Postmaster-General of England, and Member of Parliament for many years, is a British subject, of great distinction and world-wide fame.

As under the present distressing circumstances, the American Consulate has been requested to extend its good offices to the British Subjects, I hereby bespeak, for Sir Henniker Heaton, any and all aid that it may be possible to extend under your jurisdiction in expediting this peaceful and speedy progress on his lawful occasions, both as a British Subject and as a Benefactor of the Human Race.

George Platt Waller, JR., American Vice and Deputy Consul.

Given this 3Ist day of August, I9I4.

Sir John was in bad health when he left Carlsbad, and on the journey home he was greatly agitated by the news of the "victorious German armies" which was circulated abroad. He was taken seriously ill whilst travelling, and only succeeded in reaching Geneva. For three days he lay unconscious, and died on the morning of September 8th, I9I4.

Words are inadequate to describe the kindness and sympathy of Lord Westbury, who did all for his friend that was humanly possible-all indeed that the nearest relative could have done-to obtain the best advice for Sir John while life lasted, and, when the end was approaching, to soften the blow to Lady Heaton as gently and considerately as might be. When all hope was over, he wrote :

\section{Dear Lady Heaton,}

This is a most painful letter for me to have to write to you but I feel I must supplement my two 
telegrams (which I hope you have received) with some details of your dear husband's illness; and, as it is quite uncertain when we may be able to leave, it is right that you should have some news as soon as possible. For some ten days before we left Carlsbad, on 2nd Sept., he took up his residence at my hotel in order to have the benefit of the services of my valet, and I naturally saw a great deal of him as we always had our evening meal together. He talked to me a great deal, and was constantly looking forward to seeing his "dear little wife," and so far as I could judge he was far better in general health on the eve of our departure than he had been during the whole of his stay at Carlsbad; he was naturally very much upset at England going to war, and very much excited when news of disasters kept pouring in. We left in a special train for the Swiss frontier on 2nd Sept. and he and I occupied a first-class coupé and he bore the journey to the frontier exceedingly well, although he was perhaps rather imprudent in the matter of diet, and I often congratulated him on his ability to eat the unpalatable provisions we had to consume; at the Swiss frontier we found a special train ready to bring us to Geneva, and before changing trains at 4 a.m. I took care to see that he was properly wrapped up, and he was most cheerful and said that he had got on a very warm undergarment that " his dear little wife" had specially provided for him. I put him in the Swiss train, and then had to leave him as I was very busy making arrangements with Cook's agent on various matters connected with a lot of indigent English people for whom I had funds, and I also had to send several telegrams connected with our possible departure from here to the British Minister at Berne and the British Ambassador at Paris. I also had to arrange with passengers in various parts of the train about guaranteeing the cost of special from Geneva to England, etc. etc., the consequence 
being that I did not see him for about a couple of hours. Just before reaching Zurich about 6.30 a.m. my valet came to tell me that Sir Henniker had violent pains in his stomach and that Sir Benjamin Franklin (a distinguished retired Surgeon-General) was looking after him. I immediately went to him and found him in great agony. On arrival at Zurich we telegraphed to Berne (the next place we stopped at) for a doctor to bring some morphia and other remedies down to the station; at Berne the doctor appeared, but before anything could be done the train was hurried off, and the doctor had to jump down when the train was moving and all he could do was to give me the address of a doctor at Geneva. He was somewhat easier between Berne and Geneva and I was in hopes that the gastric symptoms were improving. Within 5 minutes of his arrival at Geneva station he was in this hotel, and in another five minutes (before he had time to undress) he was in the doctor's hands; this doctor, who could not speak English, informed me that he was suffering from an acute gastric attack and he prescribed accordingly. Some two hours afterwards my valet came to tell me that Sir Henniker was not feeling any relief and that he insisted upon having a doctor who could speak English. Sir Benjamin Franklin and I decided to call in a Professor Major who was strongly recommended to us. By the time he arrived your poor husband was practically unable to answer any questions, and Professor Major admitted that under the circumstances he could make no attempt to diagnose the case. A few hours later, Mrs Barton, ${ }^{1}$ an English lady living at Geneva, whom I have known for many years, came to see me and strongly recommended that a Professor Girard, whom she described as by far the cleverest medical man in Switzerland, should be sent for; and I have ascertained since beyond

1 Mrs Barton is a daughter of the late Sir Robert Peel, and her husband was for many years British Consul at Geneva. 
doubt that Professor Girard fully deserves such a reputation.

He came and had a long consultation with the 3 doctors and Sir Benjamin Franklin and quite convinced them that the gastric attack was merely an incident, and that the real trouble was a cerebral one caused by an aneurism, and that there was scarcely any hope after taking into consideration your poor husband's age and the fact that he had suffered from a stroke before; and he advised that the most humane thing to do was to leave him quietly in his bed in the hope that nature would come to his assistance; in this Sir Benjamin and I quite agreed. He was quite unconscious and suffering no pain and he has remained so ever since. Last night his temperature went up suddenly to Io6 and we feared the worst; this morning at 9 a.m. Dr Girard came again with the other doctors, and I am grieved to say that they all pronounced that the case was hopeless, and I fear I shall have to send you a final telegram within less than twentyfour hours. I can assure you that everything possible has been done for him, and Sir Benjamin Franklin has been a tower of strength, and I really don't know what I could have done without his help. Of course I will remain until the end and you can rely upon my acting as I should do in the case of any near relation of my own. I will come to see you on my return home and I will bring back all his papers and belongings. Sir Henniker was much beloved by all his Carlsbad friends and his illness is a great shock to many of them who have accompanied him from Carlsbad. I am very very sorry for you and his family.

Believe me with much sympathy,

$$
\begin{aligned}
& \text { Yours sincerely, } \\
& \text { WESTBURY. }
\end{aligned}
$$

The telegrams sent by Lord Westbury announcing the end did not reach Lady Henniker Heaton for some 
days, and it was from the morning papers that she first learnt of her irreparable loss.

Later, Lady Henniker Heaton received a letter from Mr Oswald Cheeke who was with Sir John at the end. In this letter there was given to Lady Henniker Heaton the supreme consolation of a knowledge of the Love that is stronger than Death.

Sir John had lain unconscious for three days; as the end was seen to be imminent, Mr Cheeke spoke to Sir John saying he was writing to Lady Henniker Heaton, but he could not succeed in rousing him. Mr Cheeke then bent down and spoke Lady Henniker Heaton's Christian name " Rose." The beloved name alone could break through the silence and pierce through the deepening shadows of death. Sir John raised his head to speak his last word "Love" and fell into a deep calm sleep in which his spirit passed away.

"I know that death is nothing but a shadow,

That nothing ever dies.

I seem to see Love clasping Life triumphant

With glory in his eyes."

E. W. 
Telegram from His Majesty King George to J. Henniker Heaton (eldest son) :

The King has heard with much regret of the death of Sir John Henniker Heaton, and desires me to convey to you the expression of his sympathy with you and with Lady Henniker Heaton in your sorrow.

STAMFORDHAM. 
APPENDIX 



\section{APPENDIX}

A MORNING WITH THE POSTMASTER-GENERAL

A popular article was written in I907 by H.H. in the "Nineteenth Century" in order to expose the "red-tape" methods of the Post Office. Its publication met with so much appreciation and amusement that it is here reprinted.

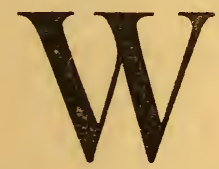

$\mathrm{E}$ all form mental pictures of unseen potent individualities who influence our lives and fortunes. In these unvarnished pages I propose to give the popular notion of the Postmaster-General at work. It would be unfair to accuse me of malicious caricature and exaggeration. I am not, be it distinctly understood, giving my personal impressions of the distinguished holder of the great office of Magister Nuntiorum. I do not paint him as he appears to his numerous friends, an able, conscientious, amiable man; but such as he must loom before the general public who only know him through his replies to their complaints, and his official attitude to the reforms they have at heart. He may do well to ponder the picture, unflattering as it seems.

\footnotetext{
"O, wad some power the giftie gie us

To see oursels as ithers see us!"
}

The Postmaster-General of the United Kingdom of Great Britain and Ireland has taken his seat in his office at St Martin's-le-Grand and the Secretary enters, 
while a huge basket of letters is borne in by a sturdy porter.

The Postmaster-General: It is satisfactory to know that the annual profits of the British Post Office exceed five millions sterling. It has occurred to me to ask you for a list of the requirements and grievances of the public.

The Secretary: We have been forced to grant over fifty so-called reforms during the past twenty years. What is the result? Here are a bundle of letters asking for at least fifty more!

P.M.-GEN.: What is that in your hand?

SEC. : Another long lecture from the hon. member for Canterbury, urging us to institute universal penny postage, and to purchase the cables for the State. He says there is intense feeling in commercial circles on both subjects, and declares that the attitude of the department will sooner or later be recognized as one of criminal neglect; that in this crisis in our economic history the Post Office is strangling every nascent industry, and facilitating foreign competition ; that we resemble the savages in the Pacific who cut down trees for the sake of the fruit, etc., etc.

P.M.-GEN.: That will do-I will reply to that myself. Give it me. Thank you. He will send our response to "The Times"; and your inexorable head-masterly style would be meat and drink to those ravening leader-writers.

SEc.: Here are two letters on which action should be taken. They reveal a gross evasion of the law. A New York lady says that all letters sent to her in Canada from England are redirected to her in the United States without extra charge. It is one penny postage from Canada to the United States, so that she 
enjoys penny postage from Great Britain to New York.

Then again here is a letter from Mr George Marples of Omaha saying that he sends his letters for England to his Canadian house and they are redirected to England free of extra charge, so he enjoys penny postage to England.

P.M.-GEN.: This is an awful state of affairs, but I am afraid we are powerless. I believe those flippant Americans would maintain this abuse as an excellent joke ; and the Canadian Post Office would laugh the loudest.

\section{EXPRESS LETTERS, ETC.}

SEc. : Here is a closely reasoned letter urging that the time has arrived for a final and necessary development of the express delivery service of letters in London and large cities. The correspondent sends a specimen of an express delivery stamp, threepence in value, to be sold at every post office. Any letter posted bearing this stamp will be despatched by a bicycle rider immediately on receipt at the office of delivery on any day of the week up to a late hour. The bicycle riders would leave the great post offices in the S.E., S.W., E.C., and the other dictricts every hour. The writer estimates that the revenue will be increased by a million sterling per annum. Every merchant and person of means will carry these special delivery stamps with him.

P.M.-GEN.: Inform the writer that I will look into the matter; but it would take considerable time to carry out such a reform. I remember I have before me also a suggestion also that the time has 
arrived for expediting delivery of the mails in large towns by establishing three classes of mail matter :I. Letters and post-cards; 2. Newspapers ; 3 . Parcels; which respectively should be delivered by first, second, and third-class postmen, priority in delivery being given to the first class.

SEC.: A writer from York asks that cartes telegrammes should be introduced-i.e. correspondence should be transmitted from one part of a city to another through pneumatic tubes at a special rate.

P.M.-GEN. : Let him wait for a perfecting of the express system : I don't approve of these underground methods.

SEC. : Here is a letter from a Glasgow man saying his letters are not delivered until 8 o'clock, whereas he got them twenty years ago at 7.30 a.m., before he went to business, and now he sometimes does not get his letters until night time. He has been told that the postal system generally has increased so much that individuals must put up with the inconvenience. He does not think this reply satisfactory.

P.M.-GEN.: Just acknowledge his letter. You cannot satisfy that type of mind. At least he gets more time for digesting breakfast, besides half an hour's respite from bad news.

SEC. : A querulous person complains that " though living in the heart of London, I never get any letters here, by any chance, until a quarter-past eight in the morning, and frequently the last post, due at 9 p.m., is not delivered until ro p.m. As you are aware, there is no delivery of letters on Sunday; which puts anyone like myself, who has a large correspondence with the Continent, to great inconvenience; there is no proper outgoing mail to the provinces on that day; 
I have to pay a penny extra in order to send a foreign letter on the same day by the night mails, and even so I have to go, or to send, to Central District offices. Worse than all this, and a positive outrage upon six millions of Londoners, it is impossible to have a letter delivered on Sunday at a less cost than Iod. This sum I have frequently paid during the last few months, owing to serious sickness in my family. It is all very well to say that I can use the telegraph, if away; but a telegram costs $6 \mathrm{~d}$. and you cannot possibly say in a telegram what you may wish to say in a letter.

"There is no metropolis in the world that is so shamefully served in the matter of letters, especially in the matter of this outrageous Sunday interdict, as London."

P.M.-GEN. : This is one who would set fire to the Post Office to roast his eggs. Snub him.

\section{WRONGS WITHOUT REMEDY}

SEC. : Now we have numerous attempts to make you pay for accidents to postal packets during transmission. The favourite argument seems to be that, since a common carrier is liable for loss or injury of goods entrusted to him, you ought to be. They forget you are not a common carrier, but a State official, protected from liability by Act of Parliament.

P.M.-GEN. : The total liability for loss and damage would be but a small portion of my annual profit, but I cannot disobey an Act of Parliament.

SEC. : Here is our answer to a claim for some postage stamps stolen by a postman : 
General Post Office, London, October $3 r d$.

Gentlemen,-I am directed by the PostmasterGeneral to refer to your communication of the 29th ultimo on the subject of an unregistered letter addressed to you by Mrs G. Gregson, Warden Law, Houghtonle-Spring, posted on the Ist of June last, which was found, minus $5 \mathrm{~s}$. postage stamps enclosed by the sender, in the possession of a postman who was arrested on the 22nd of June last for stealing letters.

The Postmaster-General regrets to say that he has unfortunately little doubt that the missing postage stamps were stolen by the postman in question. But, as you are aware, he is by law exempt from liability in respect of the loss of any postal packet; and he only accepts liability in respect of postal packets (other than those sent by Parcel Post) when they have been registered.

The Postmaster-General is sorry for the loss sustained by your customer; but, as she neglected to avail herself of the system of registration, he is precluded from entertaining any claim for compensation. I am, gentlemen,

Your obedient servant,

F. WICKHAM.

P.M.-GEN. : An excellent letter, mild yet cogent. How is it these people will not take the caution to register?

SEC. : Their flimsy pretence is that the charge for registration, twopence, is too high.

P.M.-GEN. : Ha, ha!

SEc.: Ho, ho, ho! The Rev. C. F. Roberts, Abergele, North Wales, complains that a friend sent him from Madeira some embroidery, value $£^{I}$, IOs., unregistered, and that the parcel was delivered soaking wet, having come in contact with port wine. The 
parcel was opened in the presence of the postman and a form filled up noting the condition of the contents spoilt.

The Post Office refused compensation.

P.M.-GEN. : Write offering to dry the lace for him. If discoloured, it will appear antique, and be of more value. As to the smell of wine, none but a rabid teetotaller could complain of that.

SEC. : Here is another :

LONDON: June I8th.

SIR,-We are large manufacturers of typewriting machines. We sent one of these machines carefully packed to a customer. We insured it and paid a special extra fee for insurance. The machine arrived broken, and we have had to compensate the owner. Will you please after examining into the case and ascertaining the truth send us $f_{\mathrm{I}}$, IIs. $6 \mathrm{~d}$.

Yours faithfully,

F. \& Co.

One of our able officials, suppressing his natural indignation, has written this reply:

I am directed by the Postmaster-General to state that you will see on p. 69 of the "Post Office Guide" that he is relieved from all responsibility even had he been satisfied that the parcel was properly packed, and no claim for compensation can be entertained.

P.M.-GEN. : A calm and dignified rebuke.

SEC. : The next is simply outrageous; I trust it may not make you feel unwell : such letters sometimes upset my assistants so seriously that I have to give them a week's leave. 
I write to ask why should the Post Office not be liable just the same as any other common carrier for all goods lost or stolen while being carried. It's too ridiculous that a taxpayer should both suffer from democrat confiscation and the remains of Norman tyranny. If any private person ran the Post Office, would they be exempted? And even if the Post Office was blameless, would not the interest of the taxpayer be to get the benefit of the principle of mutual insurance against loss? Of all people the Government should be the easiest, not the hardest, to make liable for any loss they are connected with.

P.M.-GEN.: Fortunately I am specially protected by Act of Parliament from against such rapacity.

No doubt if Carter Paterson, or some other carrying firm attempted to protect themselves in this manner the public would desert them, and decline to deal any longer with them. But I enjoy a monopoly, and these grumblers should attack that, not me.

SEC. : You may remember that at our last interview I presented you with some thousands of replypaid telegraph forms on each of which the public had paid sixpence or more. Our rule is not to allow them to be used after two months have elapsed, and to refuse to return the money to sender or receiver. The letter in my hand is from the Member of Parliament whom I named. He has a sort of talent for inventing postal grievances, which he brings the public to believe they are suffering from; and under our earliest Postmaster-General he might have been in danger of the Tower. Nothing, as you will observe, is too trivial to escape his censure : 
House of Commons.

My dear Postmaster-General,-I have to thank you for a somewhat cynical memorandum defending official morality on the subject of delayed telegram reply forms.

It does not place the Post Office in a more dignified position. One is naturally prejudiced against any debtor who pleads the Statutes of Limitation to defeat honest claims; and here the debtor is an millionaire department eluding the return of-sixpence.

My view is that these reply forms should be available for at least twelve months, and after that period the money should be given back to the sender of the original message without limit of time. This is common honesty. Your sense of humour will, however, probably be alive to the absurdity of multiplying "checks" devised, like the elaborate machinery on Rob Roy's sporran, to safeguard a "saxpence" or two.

I am, your obedient servant,

J. Henniker Heaton.

P.S.-Since writing the above a friend has sent me the following note:

\section{Hanover Souare, London, April 27th, I905.}

The enclosed reply telegraph form represents sixpence which the Post Office has been battening on for some months, and now I find, owing to an absolutely irrational rule of being only valuable for two months, it has become useless. It is impossible to imagine there can be any honest or sane reason for such a rule-at any rate, one that would appeal to any body of business men. It is almost a worse swindle than the Postal Order, one which you helped to get rid of, for in this the post authorities forfeit the money absolutely. It seems absurd to have two franked telegraph forms. Why should not they simply enclose 
one of their ordinary stamped (sixpenny) forms? This would save a considerable sum and lots of trouble. Yours very sincerely, J. Y. W. Macalister.

P.M.-GEN. : You may reply to this. We must be careful how we treat a Member of Parliament. Do not give way one inch. We cannot resist his suggestions when public opinion is stirred. But it never is over these small matters. Refuse to budge, but avoid acerbity, as far as possible: in any case avoid argument.

\section{Telegraph Charges.}

SEc. : "Dublin" asks " That the tariff of charges for the transmission of telegrams shall be freed of such anomalies as have been exposed-e.g. ironworks as one word, steel works as two words, or St Leonardson-Sea as one word and Charing Cross as two words."

It is also demanded that the names of all places in the United Kingdom should be charged as one word.

"Crouch End" asks that the name of that place shall be charged as one word and inquires why Charing Cross should be charged as two words, and St Pancras as one word in a telegram. "Hastings" complains that he was charged two words for N.B., whereas Scotland with four times more letters is charged as one word. Another writer complains that s.s. was charged as two words, but Steamship as one word. Another that H.M.S. be charged as one word for the benefit of officers and men. There seems to be con- 
siderable feeling about the charge for H.M.S., though here again the amount at stake is but a penny! Here is a letter on the subject :

I take the opportunity of suggesting the iniquityas it seems to me- of the Post Office charging every bluejacket and every member of the public the letters H.M.S. as three words in a telegram. I should have thought there should have been a symbol-counting as one word-to mean His Majesty's Ship. I believe the cable companies do the same, but am not certain, but it leads to words like battleship, cruiser, etc., being substituted for the proper title H.M.S. Seeing that four figures count as one word, it would not be a great stretch to treat the three letters H.M.S. as one word.

P.M.-GEN. : Assure the writer that anything touching the happiness of the British sailor is peculiarly interesting to me; but I fear that the state of telegraphic revenue will not yet allow of this concession.

SEC. : Here are documents asserting that:

(a) Freedom of communication by cable is one of the most vital strategic interests of the Empire, and, as such, ought not to be dependent on the policy of private companies. It is in the highest degree expedient to encourage, cheapen, and facilitate communication by means of the electric cable between the several portions of the Empire. The rates charged by the cable companies, for the transmission of messages are, generally speaking, excessive and in some cases prohibitive. The foreign and Colonial trade of the United Kingdom is absolutely dependent on the free use of the cables. The British Government -if possible with the co-operation of the chief Colonial Governments-should acquire the rights and property of the cable companies at a valuation (on their present 
market value) and work the cables, at the lowest remunerative rates, with a view to the utmost possible employment of the wires by day and night for the benefit of all her Majesty's subjects.

(b) That, since the charge for telegrams in both France and England does not exceed a halfpenny per word, the rate from England to France should be one penny per word, instead of twopence per word as at present. That telegrams should be sent also to Belgium, Holland, and Germany for a penny per word, and reductions in rate made in the case of Egypt and other countries.

(c) That the cost of a telephone message between London and Paris be reduced to $2 \mathrm{~s}$. $6 \mathrm{~d}$. for three minutes' conversation, instead of $8 \mathrm{~s}$. as at present.

One person observes that it is more expensive to speak through the London-Paris telephone than to utter libels and slanders at a public meeting.

Here are letters from members of the publiccormorants-asking that the names and addresseenot exceeding eight words in all-of the sender and addressee of a telegram should be transmitted free; and that twenty words in place of twelve words shall be sent for sixpence.

P.M.-GEN. : Point out that we lose heavily on telegraphs; but do not explain why-that it is chiefly because we bought them so dear, and have to pay heavy interest - that would be turned against us.

\section{Post CARDS}

SEC. : Now for a halfpenny grievance :

SIR,-You will confer a great favour on the community at trifling cost to the department, and remove 
a constant source of irritation and annoyance, by ordering that all official post cards shall be sold at their face value-that is, a halfpenny each, in place of three farthings. You now charge a penny for a post card; why not, therefore, a halfpenny for a halfpenny post card? The richest Post Office in the world should be above wringing farthings from the poor ; and, if it must differ from other Post Offices (as it does in this matter), let it be in the direction of liberality. England is the only country in the world that charges more than face value for post cards. At Gibraltar I can buy halfpenny post cards for a halfpenny each. In that out-of-the-way country, Guatemala, post cards are sold at their face value.

Yours faithfully,

A.

P.M.-GEN.: Tell the correspondent I regret I cannot afford to sacrifice the halfpence.

SEc. : Ever since we gave the public a halfpenny post card (the "letter of the poor") we have been badgered on the subject of the rules regarding them. What are we to say to this?

BELFAST.

SIR,-I beg to ask whether your attention has been directed to the fines imposed on the public for affixing stamps on post cards on the back in place of the address side; whether there is any justification for your officers obliterating with stamping machines the stamps so affixed in addition to fining the receivers of the post cards ; under what rule or postal regulation fines are imposed for stamps so wrongly affixed; and whether there is in the rules any penalty for affixing stamps on the backs of letters in place of the address side.

Yours truly, 
P.M.-GEN. : Write telling this fellow that we all hate halfpenny matter, and that the stamp must be affixed on the address side. Tell him, too, that I do not propose to alter the rule. Put our reason obscurely, but the decision emphatically. No penalty is imposed for affixing stamps to the backs of letters; but I do not propose to alter the rule.

SEc. : What about this?

St LEONARDS-ON-Sea, August I3th, I906.

SiR,--Yesterday morning (before I was down) my servant took in five post cards each bearing a penny stamp on the back in place of the address, and I had to pay Is. 3d. for them.

They were sent me by the Maire of Treport, and I should imagine that this abominable surcharge does not arise in the French Post Office, or surely he would know of the irregularity.

Yours respectfully,

H. H. W.

P.M.-GEN. : Inform this correspondent that the charge of $3 \mathrm{~d}$. on each post card represented double the deficient postage at the letter rate, and was therefore rightly collected on each card. I do not recognize the penny on the back of each card.

SEC. : Now comes a discontented stationer.

SiR,--Your department charges me 20 to 30 per cent above cost price for printing halfpenny stamps on " private post cards" sent to them for impression. I save them the trouble and expense of supplying me with gummed and perforated halfpenny stamps by forwarding I00,000 post cards for the impression. I ask that the charge be abolished.

Yours truly,

B. 
P.M.-GEN. : Tell this correspondent I cannot afford to comply with his request. Hint indirectly that we regard the "private" post card as a specially odious and illegitimate missive.

\section{Miscellaneous Complaints}

\section{SEC. : Listen to this ungrateful man :}

Sir,-You charge me 2s. for a book of stamps of the value of Is. II $\frac{1}{2} \mathrm{~d}$. I beg to enclose you a similar book of stamps issued in Switzerland with twentyfour stamps for twenty-four pence or the equivalent. Why not charge face value as in Switzerland, where the people are not so rich as in England?

Yours truly,

P.M.-GEN. : Tell the correspondent I cannot afford it. Do not let out anything about our total profits on stationery.

SEC. : They even complain of the newspaper rates. Hear this :

WOODBRIDGE, SUFFOLK.

SIR,-I beg to enclose two newspaper wrappers, one from New Zealand on which was a penny stamp, and the other to New Zealand containing an illustrated paper of exactly the same weight, and for which I am charged $3 \frac{1}{2} \mathrm{~d}$. Why has a New Zealander to pay to England less than a third of the price I have to pay for a similar newspaper from England to Wellington (N.Z.)?

Yours faithfully,

$$
\text { J. L. }
$$

P.M.-GEN. : Inform this correspondent that I cannot see my way to make any alteration in the 
charge. Give no reasons. This complaint is as unreasonable as another which has reached me-namely, that the cost of postage of the "Nineteenth Century" to Canada is one penny, but that we charge $3 \mathrm{~d}$. for sending it to any part of England. From a Post Office point of view the colonists are spoilt children.

SEC. : A number of letters are from country people asking that letter-boxes be attached to all through trains, and even to tram-cars on the principal lines. Here is one of them :

With reference to the point I raised of a travelling post office on the mail train. If we could send off letters by the 2.20 p.m. train to the Continent we should save a day on the passage between London, Switzerland, Italy, and Southern France. It would mean that anyone writing to me in Lucerne and posting his letter on the train at six o'clock in the morning in the summer would secure my receiving it the next morning. I could then reply the same day and send my letter by the $2.20 \mathrm{p} . \mathrm{m}$. mail train, and he would receive my reply on the morning after. If my letter had to wait till the next service it could not be delivered in Lucerne till one day later.

P.M.-GEN. : Point out that this would involve an expenditure of at least eighteenpence for each " travelling" letter-box, and regret that I cannot see my way to face this.

Sec.: We have repeatedly received the following suggestion :

Sir,--It would be a great convenience to the public to send the money with the postal or telegraph Money Order to the residence of the person to whom it is addressed: They do this, to the great convenience of 
the public, especially tradesmen, in India, Germany, and other countries. Fourteen million journeys to the post offices would be saved every year. How much better it would be for one postman to deliver two hundred Money Orders than for two hundred. individuals to walk to the post offices to get the money. The German system, too, is a guarantee that the money is safely delivered to the right person, while thousands of hours of valuable time are saved to the people.

Yours truly,

E.

\section{A Manchester merchant begs :}

That the mandat-carte system so successful and profitable on the Continent shall be brought into operation in this country-the money being delivered with the mandat at the payee's residence.

P.M.-GEN.: This is absurd. If a man is too important to go to a post office for his money, let him send a clerk. They may be bold enough to trust to the letter-carrier's honesty in Germany and elsewhere ; we shall not be so foolhardy. But do not, of course, refer to the second reason.

SEC.: Another complainant requires that the charges on inland telegraph Money Orders should be reduced and the money sent with the order to the residence of the receiver as in Switzerland. A prominent Member of Parliament writes that he sent Is. Id. for a magazine, and he had to pay Is. 5 d. for the telegram in addition.

P.M.-GEN. : Say this must have been an emergency which could not often recur.

SEC.: Here are nearly a hundred letters from people who complain that we will not redirect their correspondence because they were living in boarding- 
houses or lodgings. They are a lot of people mostly without votes, and of no importance, and we therefore do not see why we should give them the facilities they desire. I have drawn up and printed a letter to answer all such complaints as the one I will read, which is from some medical man:

Harley Street, Cavendish Square, W.

Sir,-I have moved to - in the same postal district. As my private address has, unfortunately, got on to the Parliamentary register, people will direct letters to my old address, and I am quite helpless to prevent their doing so. This involves delay, and sometimes very serious inconvenience.

Would you oblige me by drawing the attention of the Postmaster-General to the grievance, and ask that lodgers may be placed on the same footing as householders.

\section{Yours very faithfully,}

$$
\text { J. F. L. }
$$

P.M.-GEN. : Inform the correspondent civilly that his request cannot be granted.

SEC.: Here are numerous letters from persons complaining that their cross-country posts are deplorably deficient, and arranged so badly that the "Times" or "Daily Mail" reaches Paris before it gets to their homes in Dorchester and other places.

P.M.-GEN. : Send the usual official answers. They must live in some place where our mailing arrangements will be more satisfactory to them.

SEC. : Some fussy man writes :

SIR,- - I enclose a prospectus just issued for a motor mail coach company, in which it is stated that each motor mail coach will produce a profit of $£ 35^{\circ}$ per 
annum to the contractor. Would it not be possible to have these vans made at Woolwich Arsenal and driven by Post Office officials or soldiers? The Post Office has already a staff of highly skilled mechanics in its engineering department.

$$
\begin{aligned}
& \text { Yours truly, } \\
& \text { J. G. }
\end{aligned}
$$

P.M.-GEN.: If the Post Office were a private business of course I would do this. Tell the writer that I will give the matter careful consideration. But it would involve such a disturbance of well-settled routine that I see little hope of adopting it.

SEC. : A writer asks that registered benefit societies should be permitted to open current accounts at the Post Office Savings Banks.

P.M.-GEN.: I will consider this. Their money cannot harm us.

SEC.: Someone alleges that the late Sir W. Harcourt thought that all Post Office expenditure for sites and buildings should be carried to a capital account and spread over several years instead of being defrayed out of current revenue.

P.M.-GEN.: He did; but, though a great man, he was never Postmaster-General.

SEC. : Somebody at Norwich begs that the " cash on delivery" system should be introduced.

P.M.-GEN. : Tell him it is feared the stores would flood the country with goods and ruin local shopkeepers. I do not myself fear it, but you are not to reveal that.

SEC.: One from Edinburgh begs that the commission on foreign and colonial Money Orders should be reduced. He points out that from Paris to London a penny is charged for commission on a five shilling 
order by the French Post Office; but from London to Paris the English Post Office charges fourpence for commission on a five shilling Money Order.

P.M.-GEN. : Tell him I am of opinion that fourpence is a fair charge for such a convenience. These Scots are very keen to save a bawbee. Hint very delicately that it is open to him to reside for the future in Paris.

SEC. : A colonist thinks that the parcel rates to the Colonies should be made uniform and greatly reduced. There are thirty-eight different rates to the seventy-four countries in the list based on no common principle, the charges being in most cases higher to our Colonies than to foreign countries.

P.M.-GEN.: The Post Office is primarily a lettercarrying agency, and senders of parcels are not entitled to dictate our arrangements. In my opinion the Colonial Parcel Post tariff is a model of symmetry and liberality.

SEc.: A peremptory person demands that the repeated applications of the Australasian and other Colonies for an exchange of Postal Orders between Great Britain and her dependencies should be immediately complied with.

P.M.-GEN. : Colonial ideas are not necessarily to prevail here. Did they not try to force Preference on us? Tell him that of all the wild and visionary Imperialistic schemes-no, say merely that there are grave objections to his proposal.

SEc.: A philatelic collector states that the present illegible, indistinct, and smudgy postmarks on letters cause general dissatisfaction. The clean and distinct American postmarking machine should, therefore, be introduced in the British postal service. 
P.M.-GEN.: These marks give us satisfaction, for they render it more difficult to prove delay in transmission. But say that the American machines are being slowly introduced, and will in the course of a generation-no, of a few years-be universal.

SEC. : A publisher asks that the rules requiring a periodical, in order to pass as a " registered newspaper," to be published at intervals not exceeding seven days, and to contain a certain proportion of news and articles of a given character should be abolished, so that such magazines as the "Nineteenth Century" should no longer be excluded from the advantages of the newspaper postage. He says that a paper weighing $2 \frac{1}{4}$ pounds goes through the post for a halfpenny, and a magazine the same weight is charged $8 \frac{1}{2} \mathrm{~d}$.

P.M.-Gen. : My hands are tied by Act of Parliament. But personally I regard this excess charge on reviews and magazines as a tax on luxuries, and therefore justifiable.

SEC.: A person asks that the fine for insufficient postage shall not exceed the deficiency; that a halfpenny fine, in addition to the deficient postage, shall be the maximum for an inland and a penny for a foreign letter.

P.M.-GEN. : No doubt the sender should be fined, not the receiver; but we cannot get at the former. Our view is, that the more severely we punish the unlucky addressee, the more likely he is to revenge himself on the sender, and cure that individual of the habit of neglecting to pay postage.

SEC.: A clergyman asks that the charge for the registration of a letter should not exceed a penny. He says that he saves a penny by posting unstamped all letters requiring care, but he puts two penny 
stamps inside each. The Post Office takes very great care of these letters-more care than if they were registered.

P.M.-GEN. : He is not ashamed to cheat the revenue, and does not deserve an answer. Twopence will be the charge while I am in office.

SEC. : Two traders request that the minimum charge for the sample post should be a halfpenny for two ounces-a change greatly desired by the trading public. These firms say that if allowed to put samples of cloth or linen inside each open envelope they would increase trade enormously. One firm states that they would send a million extra samples through the post every year, and thousands of people would be convenienced. Under present rules only paper can be sent by the halfpenny post.

P.M.-GEN.: These millionaire advertising traders can well afford the extra halfpenny. Send a regretful refusal.

SEC. : A Londoner holds that as the regulations in the "Postal Guide" are drawn up in the interests of the department, and are full of pitfalls, the principles of interpretation being apparently reducible to two(I) Read the regulations as unfavourably to the public as possible ; and (2) never alter a decision once pronounced-the "Postal Guide" should be revised in the interests of the public, and the regulations should be at least grammatical and, if possible, perfectly clear.

P.M.-GEN. : Tell him codes are never light reading, and necessitate a staff of official interpreters, but that if he will revise the "Guide" on the lines he indicates and send me the draft I will -

Sec. : Pigeonhole it! Ho, ho, ho!

P.M.-GEN. : Ha, ha, ha! 
SEC. : A mechanic has devised an improved letter pillar-box, such as that of Austria or Germany, to prevent thefts.

P.M.-GEN. : Tell him this scheme has been under consideration-do not say for twenty-five years.

SEC. : We are asked: That an Imperial, and if possible also an international postage stamp be brought into use, and that until this is done a room should be set apart in each of the more important post offices in the kingdom for the sale of foreign and colonial stamps (as is done in some of the Colonies), in order to enable commercial men to send stamps for replies, etc.

Captain Montgomery (Durban) points out the difficulty he has in sending Id., 2 d., 3 d., or $6 \mathrm{~d}$. to England for replies to letters, or to buy nick-nacks, newspapers, etc., that are advertised. He strongly urges that stamps be taken from all parts of the Empire and exchanged by the British and other post offices even at a small percentage. It would be an immense convenience. The Postmaster-General of New Zealand is in favour of the proposal.

P.M.-GEN. : Our new coupon does away with the necessity for this to a great extent. Refuse.

SEc.: "Man of Kent" suggests: "That an Agricultural Parcel Post be established at special low rates for dairy produce, poultry, vegetables, fruit, etc., as a practical contribution towards the relief of the agricultural population.

P.M.-GEN.: Tell him it was suggested in the eighties. But we cannot favour one section of the population over another, even if Kent were reduced to a desert.

SEC. : Here is a heavy batch of letters complaining 
of fines for breaking the halfpenny post regulations. It is said that only two persons in the world-postal officials-profess to understand what is a letter, as distinguished from a circular letter, and that these two eminent authorities disagree. Miss W., a Dulwich Church worker, sent out twenty-one circulars (halfpenny postage) for help for Guy's Hospital. Every recipient was fined double the letter deficiency, because the amount of the subscription due was written and not printed.

P.M.-Gen.: She defied the regulation, and the subscribers must pay. Every English subject is presumed to know postal law.

SEC.: An individual complains that postmen are now no longer allowed in rural districts to purchase Postal Orders at the local office for the public and enclose them in letters left open for the purpose. Another man complains that the rural postman is not allowed to take a letter asking for a Postal Order to his postmaster unless the letter bears a penny stamp.

P.M.-GEN.: Postmen, rural or urban, must obey me. They are the servants of the department, not of the public. Refuse.

SEC. : What shall I say in reply to this?

I venture to bring to your notice a hardship to anyone buying a Government annuity. That is, the necessity of first selling out of the Government funds, at present at great loss. Surely a simple form of transfer might do instead.

For example, I wish to buy a Government annuity, but I do not wish in my old age to scramble on less than seventy pounds a year. That sum I could get after my next birthday but for this selling out, which would reduce my capital so much (as the funds now 
are) that I must put off the long-wished-for day for years. And this while every penny I possess is in the Government's own hands, in the $2 \frac{1}{2}$ per cent Consols and the Post Office.

Of course, if one could make by selling out, that would be another story, but I am told that will never be again.

Please forgive me for thus intruding on you.

P.M.-Gen. : Say I am helpless.

SEC. : A correspondent asks if the PostmasterGeneral is aware that the Post Office Savings Bank refuses to take sixpences on deposit. Will he explain why a depositor is allowed to withdraw Igs. 6d. but is not allowed to deposit I2s. 6d. in the Savings Bank, and whether he will give instructions to abolish this anomaly.

P.M.-GEN. : Tell this correspondent that the refusal of the Post Office Savings Bank to take fractions of a shilling on deposit is based on the provisions of the Post Office Savings Bank Act of I86I, and no change could therefore be made without legislation, which legislation I do not intend to introduce.

SEC. : Here is a letter from "F." (Forest Gate) complaining that he cannot put less than one shilling in the Savings Bank; and he asks you to reduce the amount.

P.M.-GEN.: Send him the usual negative answer, whatever it is.

SEC. : A letter from Rev. J. C., clergyman in Banffshire, complains that he was fined a penny because a post card sent to him had tinsel on it.

P.M.-GEN. : He ought to be fined a shilling.

SEC.: Here are letters from Liverpool and other cities complaining that registered letters to Spain 
were delivered, but minus the bank-notes. They can get no compensation, and the consul at Malaga says that letters are regularly tampered with.

P.M.-Gen.: Tell these good people that I am, under Act of Parliament, not responsible.

\section{A Consultative Committee}

SEC.: It is now lunch time and I have not gone through a quarter of my complaints.

P.M.-GEN. : What about a consultative committee ? It is unquestionably true that no business man would dare to irritate his customers as we do in the Post Office. As we have no business man in our department, might it not be worth while to adopt the suggestion made for the appointment of a permanent consultative committee of business men to sit with me and advise me as to the requirements of the public?

SEc.: There are numerous fatal objections, the first being that we officials should consider ourselves deeply insulted, and should resign in a body. The second is-

P.M.-Gen. : Say no more. Let us go to lunch. 


\section{N D E X}

A

Abdullah, Sultan, his banishment, 76,77

Aberdeen, Lord, in Edinburgh, 58

Abergele, 262

Addison, Joseph, quoted, 25

Adelaide, $\mathrm{H}$. $\mathrm{H}$. at, roo

Agricultural Conference in Jamaica, 88

- Parcel Post, 279

Alexandra, Queen, thanks H. H., 242

Algiers, I 88

Allen, Captain J. D., 47

Alverstone, Lord, on Government Whips, 23

Amettes, France, 6I

Amsterdam Exhibition, the, Io

Anderson, Sir James, on the Mauritian cable, 8I, 224

Anglo-American Parliamentary Chess Tournament, an, 52

- Penny Postage, II, 36, 83, I35, I 57, I9I-I97, 207, 247

Anglo-Australian Parliamentary Chess Match, an, 53

- Penny Postage, establishment of, II, 3I, I80, I82-I84, I99, 200, 2 IO, 2 I 5-22I

Arctic expeditions, I45, I49

Ardfert Abbey, Kerry, I 20

Arena, H. H. on cable reform in, 223

Argentine, the, H. H. in, 95

Argyll, Duke of, I Io

226 supports H. H., III, I98, 225,

Army and Navy Estimates, I 7, 30

Arnold, E. M., 50

Artillery, Royal, officers of the, I 56

Asquith, Rt. Hon. H. H., as Chancellor of the Exchequer, I9I

- on H. H., I98

Athenæum Club, the, I4I

Atherley, Hamilton, I 20

Australia, British Parliamentary party visit, ror 225
Australia, Carlyle's interest in, I5 I copper mines in, I59

gold mining in, $10,16,160$

Government of, 79, I67, I68

H. H.'s early life in, 4-9, I3I, I 58-I66, 2 I 6

H. H.'s library on, I 22

H. H. visits, $7 \mathrm{I}, 85,95-\mathrm{IO}$,

I 4 I, I 53, I68, I92, 220, 242 introduction of sheep into, 165 its contingent in the Darda. nelles, I69

its Navy, IoI

"Member for," vii, Io, I69

postal communications of, I I, 3 I,

I74, I80-I 84, I99, 200, 2IO, 2 I 5221

Sir George Reid, High Commissioner for, 43,48

tin-mines in, I65

Australian Banks, their testimonia to H. H., 242

- Commonwealth Building, the, I 4 I

Australian Dictionary of Dates and Men of the Time, The, 9, I59

Australian Town and County Journal, 5, 6

Austria, postal system of, I88, 279

B

Back River, the, I 49, I 50

Baker, Captain E. J., 72

Balcarres, Lord, as Junior Whip, 27

Balfour, Lady Frances, I I3

Balfour, Rt. Hon. A. J., I5, I07, I I I defeated in I906, 30, 3I, 86

his gum-trees, 20

Sir H. Parkes on, I67

Ballarat, I 68

Ballyhooley, I37

Banks, Sir John, Queen's Physician, I20

Barlow, Sir Thomas, I39

Barrow-in-Furness, I33

Barton, Mrs, of Geneva, 25 I

Bath, H. H. at, I39 Mr Birrell at, 22 
Bath Club, the, 197

H. H. at, 7 I, Io3, I 35, I 47

Baxter, Mr, advocates Anglo-American Penny Postage, I9I

Bayley, G. B., 50

Beach, Mr Hicks, in Buenos Ayres, 95

Beach, W. W., his silence as M.P., 26

Beechworth, Victoria, I6r

Belfast, 239, 269

Belgium, cable service to, I 40, 268 marriage in, $\operatorname{II}_{3}$

Bell, Moberly, anecdote of, I I 3

- Sir J. C., Lord Mayor, 225

Bennett, E., 50

- his tribute to H. H., 203

Bennett, Rose, her marriage with H. H., 6-8

Bennett, Samuel, doyen of Australian journalists, 5, 6, I 66

Sir George Reid's tribute to, vii

Benson, Archbishop, his letter to H. H., 46

Beresford, Lord Charles, ix, I 5 on Penny Postage, 3I-33

Berlin, International Telegraphic Conference, ro, 8I

Berne, H. H. at, 250

Berwick-on-Tweed, I 73

Besant, Mrs, 67

Bexhill-on-Sea, H. H. at, 57, r 38

Biarritz, x90

Bicester, Middleton Park, 99

Big Ben, I 8

Diamond Syndicate, the, I6I

Bignold, Sir Arthur, on telegrams, I 99

Bills, James, $5^{\circ}$

Birch, James Woodford, murder of, 76

Birmingham, I8o, 242

Birrell, Rt. Hon. Augustine, on Government Whips, 22

Blackwood, Stevenson, I 40

Blyth, Lord, arranges the civic welcome of H. H., 242-246

- H. H.'s correspondence with, I 28, I $38-142,247$

his friendship with $H$. H., ix, 49, I 37

- his interest in Penny Postage, I 89-I94, 247

- supports cable reform, 225

Boer War, the, 227

postal grievances of, 208, 209

Boldrewood, Rolf, Robbery under Arms, I 66

Book-collector, H. H. as a, I03, I22

Booth, General, 67

\section{Boothia, I 49}

Bores, Parliamentary, 26

Borton, Sir Neville, P.M.G. of Egypt, 204

Boulanger, General, in Paris, 243

Bourne, Hon. Clarence, Chief Secretary of Jamaica, 88

Brackenbury, General Sir Henry, Lord Wolseley on, I 56

Bradlaugh, Charles, I 5

- as a chess player, $5^{\mathbf{I}}$

Bremen, I 38

Brian, M., P.M.G. of France, I90

Bribery in Canterbury, 42

Bridge, H. H.'s love of, 143

Bright, Charles, on cheap cabling, 226

- John, I 5

Brindisi, 200

- Laurentius di, 6r

Brisbane, 9

Bristol, 93

Britain, Harry, inaugurates the Imperial Press Conference, 227

British Empire, federation of the; 80

—_ League, welcomes H. H., I I, 242246

British Navy, the, I 54

- Parliamentary visit to Australia, Ior

Broadstairs, 206

Brougham, Lord, his anecdote of a new M.P., 25

Brown, Tom, sketches by, $\mathrm{x} 43$

- waiter, I8

Browning, Robert, 207, 233

Bruce, Sir Charles, ix

- his Mauritian policy, 80, 8x

- his tribute to H. H., I 76-179

- supports cable reform, 223

Brunton, Sir Lauder, 122

Bryce, Lord, on his Ambassadorship, 36

Buchanan, Mr, 72

Buckle, Mr, I66

Buenos Ayres, H. H., in 95

Bulwark, H.M.S., 3I

Burnham, Lord, 227

Burns, John, High Commissioner for South Africa, 49

Burrell, Hon. K. M. S., her marriage, I I, II9

Burritt, Elihu, as postal reformer, I73

Butt, Clara, 42

Butters, J. S., I6r

Buxion, Viscount, as P.M.G., I9x-I94, 207 
C

Carson, Sir Edward, on Home Rule,

Cable service, the, between the Cape and Australia, I0, 81, 224, 225

between England, France and

Belgium, I 40, 268

chess by, 52

Deferred Message system, 228

grievances in, 2 I I

H. H. advocates reforms in, I 57, 222-23 I 267

ipenny-a-word, 49, I95, 222-23I,

Calais, postage to, 183,187

Calcutta, 74

Callard, A. O., 50

Cambon, H. E. Paul, French Ambassador, I90

Cambridge, University of, chess tournaments of, 54

Camden Park, I65

Cameron, Mr, storekeeper, I6I

Campbell - Bannerman, Sir Henry, I I I

Lord Charles Beresford on, 33

Canada, Duke of Argyll, Governor of, I IO

H. H. in, 87

- imperial news in, 227

its postal system, $48, \mathbf{1} 78, \mathbf{r} 8 \mathrm{I}$, I $83,258,259$

Cannes, H. H. at, 66

Canonization, the ceremony of, 59

Canterbury, a fire at, 68

Cricket Week, 4I

- H. H. a Freeman of, I I, 39, $24 I$

H. H. as M.P. for, II, I3, 37, $39-50,55,63,68,87$, I $_{32}, \mathrm{I}_{35}, \mathrm{I}_{45}$, I 53

New Zealand, 43

Cape Colony, its cable communications, $8 \mathrm{I}, 224$

its postal relations, $I 8 I, 20 I$

Carlsbad, I 4 I

H. H. in, 59, 108, 135, I38, $21_{3}$, 248-250, 252

Carlton Club, the, 67,246

- H. H. as member of, 83 , II5, I23, I 37

Carlyle, Life of, by Sir C. G. Duffy, 66

Carlyle, Thomas, H. H.'s interview with, I 5 I

Carnarvon, Lord, H. H. meets, I40

Carnegie, Andrew, on postage and peace, I 56, I9I, I92

Carpathian, S.S., 98

Carter, Paterson \& Co., Messrs, 2 I I, 264

Cash-on-delivery system, the, 275

Cavendish, Lord Richard, his sale of cattle, I 4 I

Cayzer, Sir Charles, 22

Ceylon, H. H. in, 96

Chalmers, Sir Robert, Grovernor of Ceylon, 96

Chamberlain, Rt. Hon. Austen, ix

- his interest in Penny Postage, 219,220

- on telegraphic vagaries, 2 I 2

Chamberlain, Joseph, I 5 his correspondence with $H$. H., 39,97

his Fiscal policy, 33

his interest in postal reform, I76-I 81

Chamberlain, Mrs, ro7

Channel Tunnel, the, 187

Chapman, Austin, P.M.G. of Australia, I82, 220

Charing Cross Post Office, 238

Cheeke, Oswald, his letter to Lady Heaton, 253

Chess, H. H.'s love of, 5I-56, 70, Io3

Chester, I73

China, H. H. in, 82

postal communication with, 200 , 207,220

Ching-Fong, Li, on Penny Postage, 208

Chisholm, Mrs, the Emigrant's Friend, $2 \mathrm{I} 5$

Choate, Joseph, his compliment, I22

Churchill, Lord Randolph, anecdote of, 18

- as a chess-player, $5 \mathrm{I}$

- at. Monte Carlo, 63

H. H.'s relations with, I5, I7, I 8, 3I

Churchill, Major Winston, 108

Chulan, Rapas, 77

Cimiez, H. H. at, 63, 68

Clarke, Sir Edward, I 5, 49

Clarke, Sir Fielding, in Jamaica, 89

Clemens, Samuel, I97. See Twain

Clerkington, I 20

Clifford, Sir Hugh and Lady, their friendship with H. H., 96

Clinch, G., 50

Cockburn, Sir John, 49

Collard, Sir George, Mayor of Canterbury, 39, 40

Collins, Captain Muirhead, on cheap telegraphy, 225 
Collinson, explorer, I $50, I_{5}$

Cologne, H. H. at, 63

Colombo, 72, 75

Colonial Conference, First, 217

- Exhibition, Indian and, ro

- Hereditary Peerage, a, 167

- Office, its policy with regard

to Mauritius, $79-8 \mathrm{I}$

Parcel Post, 276

visitors in England, I I0, I I 5, I34

Colonies, the, their relations with England, 155

Comet, wreck of the, 160

Commerell, Admiral Sir Edward, his breach of parliamentary order, I9

Compulsory training in New Zealand, I 39

Conciliation Bill, 2 I

Conference, International Telegraphic, in Berlin, 10, 8I

Conservative Party, the, their defeat in $1906,29,3 \mathrm{I}-33$

Constantine, Captain, in Jamaica, 88

Cooper, Fenimore, novels of, 3

Cooper, Thomas Sidney, R.A., anagram on, 148

Cork, Hon. Mr, in Jamaica, 88

Cotton, Sir Richmond, his address to H. H., 240

Coupon reply stamps, 279

Covarrubias, M., on Penny Postage, 208

Cowper, Maggie, 2 Io

Cricket, H. H.'s love of, $4 \mathrm{I}, 4^{8}$

Cromwell, Oliver, I26

Crowe, P. W., on H. H., 9

Curzon of Kedleston, Earl, his correspondence with $\mathrm{H}$. H., 35

- his tribute to H. H., ix, II, 242244

Cust, Henry, on H. H. as correspondent, I 2 I

\section{$\mathrm{D}$}

Daily Chronicle, The, quoted, $\mathrm{I}_{4} 8$

Daily Graphic, The, ix

Dardanelles, the, Australian contingent in, I69

Dartmouth, Lord, on Anglo-French postage, 189

Davidson, Colonel Sir Arthur, on Anglo-French postal relations, I90

De La Rue, Messrs, their Post Office stationery contract, 200

Denman, Lord, Governor-General of Australia, 99

Denominational Schools of Australia, 9
Deptford, M.P. for, 5I

Derby, Earl of, 218

D'Eresby, Lord Willoughby, I 20

Devonshire, Duke of, 243

Dis cattle sales, I 42

Disraeli, caricature of, 78

- on dinners, 105

Divorce Laws Commission, the, II 3

Dixon, Charles, I43

Dorchester, 274

Dornoch, 156

Doughty, Lady, as hostess, Io9

Dover, 187

H. H. at, 213

Dublin, 188,239

- H. H. in, $\mathrm{I}_{40}$

Dufferin, Lord, quoted, I 7 I

Duffy, Sir Charles Gavan, his career, I67, 168

his friendship with H. H., 34, $65-68, x_{37}, x_{5} \mathrm{I}$

- his Life of Carlyle, 66

- on Home Rule, 34, I 40

Dupont, Emil, advocates AngloFrench Penny Postage, I9o

Durban, 279

E

Earthquakes, H. H.'s experience of, $87-94$

Eastern Telegraph Company, the, opposes Mauritian cable, 8I, 224

Eaton Square, H. H.'s home in, 78 , I 05, II 7-I 25, 209, 238

Edinburgh, 239

$-\mathrm{H}$. H. in, 58

- Mr Wallace M.P. for, 2 I

Education, denominational, 9

Edward VII., King, coronation of, I06, 120

- his attitude to postal reforms, I84, I89, 190, 213, 242

kissed in Canterbury, 43

Egyptian Post Office, the, 204, 236, 268

Emden, sinking of the, IOI

England, invasion of, 170

Express Delivery, 259

F

Fallières, President, in London, I92, I93

Fergusson, Sir James, his postal proposal, $\mathrm{I} 78$

in Jamaica, 88 
Fiji, cable to, 225

H. H. in, 85 postage to, 187

Financial Review of Reviews, the, on cable reform, 223

Fiscal Reform, Lord Charles Beresford on, 33

Fleming, Canon, H. H. on, I2 I

Fleming, Sir Sandford, his interest in cable reform, 225

Forster, M.P., Arnold, in Jamaica, 88, $9 \mathrm{I}$

Fort William, 87

France, cable service to, $I_{40}$

its postal relations with England, I83, I86-r9r, 20r, 205

Franco-British Exhibition, the, 1908, I92

Franklin, Sir Benjamin, attends $H$. $H$. in Switzerland, 251, 252

Franklin, Sir John, explorer, fate of, I 45, I 49-I 5 I

Fraser, Sir William, 34

French, Viscount, supports H. H., 49, 229

Furley, Walter, 40

\section{G}

Galle, 75

Gamble, Captain D. A., 47

Gay Golfers' Club, the, 30

Geard, Reginald, on H. H. at the Savage Club, I 42 -r 44

Geneva, H. H.'s death and burial in, I 44, 248-253

George III., King, his sheep, I65

George IV., King, coronation of, I 20

George V., King, his regret at H. H.'s death, 254

- lays stone of Australian Commonwealth Building, I 4 I

George, Rt. Hon. D. Lloyd, at Monte Carlo, 64

- encouraged by H. H., 20

Germany, postal system of, r 88 , r 90 , $268,273,279$

Gibraltar, 269

Girard, Professor, attends H. H., 25r, 252

Gladstone, W. E., I5

anecdotes of, r9

his Irish policy, 34, 67 .

- Sir Henry Parkes on, 167

Glasgow, 239, 260

Glenroy, S.S., 74

Glossop, Captain John, ror

Glyn, Elinor, 108
Gold-mining in Australia, Io, I6, I60

Goonoo Goonoo Gap, ${ }_{5} 8$

Gorst, Sir John, 15

Goschen, Lord, I5, I8

Goulbourn, 5

Government annuities, 280

Governor Ready, wreck of the, I60

Graham, Sir James, First Lord of the Admiralty, ${ }_{50}$

- his death, 168

Grantham, I2I

Gravesend, 72

Green, General Sir Harry Rhodes, I06

Gregory, John William, ro4

Gregson, Mrs G., 262

Guatemala, 269

Guildhall, $H$. $H$. at the, II, $2 r$, 242

Gully, Speaker, on chess, 52

Guy's Hospital, 28o

Gwydyr, 4th Baron, I20

- $5^{\text {th }}$ Baron, 12, Ir9

\section{$\mathrm{H}$}

Haldane, Lord, II I

- meets Senator Root, r4I

Half-penny Post, the, 209, 236, 269, 278,280

Hall, Admiral Sir George King, ror

Hall, W. R., I6I

Hall-Jones, Sir William, High Commissioner for New Zealand, 48

Halsbury, Lord, I 3

- his letter to H. H., I38, I39

Hamilton, Lord Claude, as a chessplayer, 55

- enters Parliament with his brothers, I 5 .

Harcourt, Rt. Hon. Lewis, Secretary of State, 227

- his popularity, 29

Harcourt, Lady, I0 7

Harcourt, Sir William, 15,275

his correspondence with $\mathrm{H}$. H., 36,140

Hargreaves, Edward, 160

Harris, Lord, 47

Harrow, 33

Hart, Sir Robert, in Pekin, 82 in London, 83

Hassall, John, his menu for the Savages, I 43

Hasted's History of Kent, 3

Hearn, H. J., 50 J. T., 50 
Heaton, Arthur Henniker, 53

his marriage, 120

Heaton, Elizabeth Ann, her marriage, I 20

Heaton, Herbert Henniker, Assistant Colonial Secretary of Mauritius, 8r

- his marriage, 120

- in Fiji, 85

Heaton, Lt.-Col. John, 3

Heaton, Sir John Henniker, his birth and education, 3,4

- his early life in Australia, 4, r3 I, r $58-$ r66, I74

- his journalistic experience, 5

- his marriage, 6-9

— contests N.S.W., 9

as "Member for Australia," Io

settles in London, ro

— is returned M.P. for Canterbury,

II, I3, 39-50, 87, I32

- his work as a Postal Reformer,

II, I3, 3I, 83, I32, I7 I, 200-2I4, 232

- public recognition of his work,

I r, 99, 240-247

declines a K.C.M.G., II

his experiences as an M.P., I3-

36 , ro6, I34-1 36

as a chess-player, ${ }^{\mathrm{I}-56}$

- as a traveller, 57-102, r68

—- as a host, ro3-I I6, I 34

his home life, rr7-125

- his personality, I 26-r 30

- his friends, I37-I $57, \mathbf{r} 68$

- advocates Universa

Postage, I74, r 82

advocates Imperial Penny Postage, $\mathrm{r} 75-\mathrm{r} 82$

- obtains Penny Postage to Aus-

tralia, I82, 2 I5-22I

- advocates Anglo-French Penny Post, I 87-193

obtains Penny Postage to

U.S.A., I9r-I97 advocates penny-a-word tele-

grams, I99, 222-23I

his ideal post office, 233-239

his death, 248-254

Heaton, Sir John Henniker, son of H. H., I I, II9, 254

Heaton, Lady Henniker, 82

Lord Westbury's letters to, 249253

Heaton, Peter Joseph Henniker, 22

Heaton, Reginald Henniker, I4, I20

Heaton, Rose Henniker, her marriage, I02, 120

Heaton, William, ix
Hegel, quoted, I29 note

Hennessy, Sir John Pope, as Governor of Mauritius, 79

137

Henniker, John, 3

Hicks-Beach, Mr, in Buenos Ayres, 95

$\frac{95}{\text { Sir Michael, }}$ 5, 95

Hill, Harrison, his verses on Macdona, 30

Hill, Sir Rowland, Father of Penny Postage, 99, I 73, I7 $8,24 \mathrm{I}$

Holker Hall, Lancashire, I4I

Holland, 268

- Sir William, supports cable reform, 225

Holt, P. H., 50

Home Rule for Ireland, 15, 34, 67, $80,140,145$

Hong Kong, I 83

- H. H. in, 89

Hope, Anthony, on H. H.'s name, I 5 I

Houghton-le-Spring, 262

House of Commons, the chess-players of, 5 I- 56

H. H. as a host at, II2, I34, I 48

H. H. as a member of, $13-38$

H. H.'s description of life in, 23-26

Houstoun, Colonel, I20

Howard, Cardinal, 60

Hudson Bay Company, the, I5o

Hughes, Sir Thomas and Lady, in Sydney, r68

\section{I}

Idris, Sultan, 77

Imperial Chess Club, the, 55

Imperial Penny Postage, $\mathrm{H}$. $\mathrm{H}$. as Father of, II, 30, 3I, 56, 66, 98I 00, I I I, I44, I 54

- Hassall's tribute to, I44

_ Lord Charles Beresford on, 3 I

Imperial Press Conference, the first, 226

Inchiquin, Lord, I53

India, $H$. $H$. in, 82

- postal system of, $178,183,200$, 236,273

Indian and Colonial Exhibition, London, ro

International Postage, I 76

- Telegraphic Conference in Berlin, Io, $8 \mathrm{I}$ 
Ireland, H. H.'s love of, $5^{8}$

\section{40, I 45}

Irish Land Bills, I4

Members of Parliament, I5

Jacks, Newton, 50

Jamaica, H. H. in, 87

Jameson Raid, the, 32

Japan, divorce laws in, II 3

H. H. in, 57,82

postal system of, 220

Jenner, Sir William, on Monte Carlo, 63

Jersey, Lord, his support of pennya-word telegrams, 223

- his tribute to H. H., 99, roo

Johnson, Captain, I 59

Johnson, Dr Samuel, on London, 58 - Matthey \& Co., Messrs, metallurgists, I 7

Jones, Atherley, 52

Jones, Henry Arthur, at Windsor, ${ }_{52}$

Journalists, Carnegie on, I 56

Jupiter, wreck of the, 160

\section{K}

\section{Keicktak, I49}

Kendall, Henry, his Rose Lorraine, 6

Kent, H. H.'s love of, $4 \mathrm{I}, 47$

House School, 4

Kent, H.M.S., 47

Killanin, Lord, his anecdotes, I06

- his friendship with H. H., Io6, I 37

Kilmainham, Parnell in, I6

King, Yeend, V.P.R.I., at the Savage Club, I44

King's College, London, H. H. educated at, 4

- H. H. a Fellow of, 242

- School, Canterbury, 4I

King William Land, I 49

Kingston, Jamaica, H. H. in, 87-94

Kipling, Rudyard, on postal reform, I 5 I

quoted, 70, 94, I30, I65

Kitchener, Colonel, in Jamaica, 88

Kitchener, Earl, his tribute to $\mathrm{H}$. $\mathrm{H}$., 87

public grant for, 20
L

Labouchere, Henry, anecdotes of, 27

his opposition to Gladstone, 67

Labour Party, the, 32

Labre, Joseph, 6I

Lagos Bay, 3 I

Lambert, Captain Thomas, $4^{\circ}$

Lambeth Palace, 22

Landale family, the, I65

Larking, R., 50

Lascelles, Mr, I97

Laurent, Dr, his tribute to H. H., 82

Law, Rt. Hon. Bonar, as a chessplayer, 54

- at the United Service Club, I4I

Lawson, Hon. Harry, 227

Lawson, Sir Wilfrid, on his bull, I42

- on $\mathrm{H}$. H.'s postal reforms, 185

Lefroy, Dean, letters of, I40, I54. I 86

Leisure Hour, The, ix

Le May, W. H., 50

Lemieux, Hon. R., P.M.G. of Canada, 223, 226

Leo XIII., Pope, 6o, 62

Liberal victory of 1906, 29, 3I-33

Limerick, Ireland, 216

Lipton, Sir Thomas, 123

Liverpool, 239, $28 \mathrm{I}$

Lockwood, Frank, I5

Loder, Gerald, in Jamaica, 90

Lodgers' letters, 273

London, H. H. a Freeman of, II, 240 $\mathrm{H}$. $\mathrm{H}$. settles in, ro

— - Bishop of, quoted, 203

Londonderry, Lord, as P.M.G., 207, 220

Longworth, Mrs Nicholas, ro 7

- Senator the Hon. Nicholas, I9I advocates postal reform, I9I

Lucas, E. V., quoted, I 7 I

Lucerne, 272

Lyttelton, Rt. Hon. Alfred, his interest in Penny Postage, 2I9

on cricket, 48

\section{M}

Macalister, J. Y. W., 266

MacArthur, John, Father of N.S.W., 165

Macaulay, Lord, quoted, I75

Macdona, Cumming, M.P. for Rotherhithe, 29

Mackenzie, Mr, High Commissioner for New Zealand, I39 
Maclaren, Ian, quoted, 127

Madden, Admiral, his marriage, 22

Madeira, 262

Madras, 74

Magazine post, 277

Mahé, Seychelles Is., 76

Mahon, the O'Gorman, 52

Maids of Kent, the, 47

Major, Professor, 25I

Malaga, 282

Maloja, R.M.S., 98

Manchester, 239

Manchester Courier, The, on $\mathrm{H}$. H., $\mathrm{I}_{4}$

Mandat-carte system, the, 273

Marconi, Commendatore, meets Maxim, I 29

- H. H.'s belief in, 228, 229

— entertained by the Savages, I43

- his friendship with $\mathrm{H}$. H., ix, 49, 97, I06, I07, I09, II0, I29, I38, I 52, I 53,225

- his marriage, $\mathbf{I}_{53}$

- supports penny-a-word telegrams, 223

Marconi, Degnia, rog

Markham, Admiral Sir Albert, on H. H., 2 I 2

Marlborough, the Duchess of, ro7

Marples, George, of Omaha, 259

Marriage Acts, 30, II 3

Martin, Robert, his friendship with H. H., I37

Massingham, Mr, on H. H., 203

Maurice, Sir Frederick, Lord Wolseley on, 156

Mauritius, 74

- H. H.'s warm relations with, $78-82,224$

Maxim, Sir Hiram, invention by, I 29

M'Carthy, Justin, his correspondence with H. H., 37, II 2

M'Clintock, explorer, I 5 I

Medway, the, 3

Melba, Madame, anecdote of, IoI

Melbourne, 2 I 5

- Sir C. G. Duffy in, I68

Men of Kent and Kentish Men, the, H. H. as President of, 47-50

Mercury, The, Parramatta, 5

Mermaid, wreck of the, I59

Messina, Straits of, 7 I

Methuen, Messrs, I 7I

Meyer, George, advocates AngloAmerican Penny Postage, I91, I92

Meynell, Mrs, her influence, I44

Meynell, Wilfred, his tribute to $H$. H., ix, $145^{-1} 4^{8}$
Meynell, Wilfred, H. H.'s friendship with, I 44 quoted, I I 4

Mexico, postal system of, 188,207

Michael Angelo Buonarroti, 59

Milner, Lord, supports H. H., 225, 226

M'Kenna, Rt. Hon. Reginald, II I

- as a chess-player, 52, 53

Money Orders, system of, 201, 272, 275

Monte Carlo, H. H. at, 63-65, 135

Montefalco, Clara de, $6 \mathbf{I}$

Montgomery, Captain, 279

Moore, Frankfort, 30

Morley, Earl, I4I

Morris, Judge, Io6

- Sir Daniel, in Jamaica, 88

Motley, John Lothrop, Rise of the Dutch Republic, 4

Motor Mail Coaches, 274

Mount Etna, 7I

- Pleasant, I7 1

Mulock, Mr, P.M.G. of Canada, I79, I8I

Murray, David, R.A., at Windsor, I 52

Murray, Freeman, assists in the welcome to H. H., 246

Murray, G. H., on circulars, 207

\section{$\mathrm{N}$}

Natal, cable communications with, $8 \mathrm{I}$

- Sir W. Peace, Agent-General for, $\mathrm{I} 8 \mathrm{I}$

Nation, The, foundation of, $\mathrm{I} 68$

Navy Estimates, the, I7, 24

New Caledonia, 225

Newcastle-on-Tyne, 46, I33

New El Dorado, I6r

Newnes, Sir George, as a chessplayer, 5I

- on Rougemont, II 5

New Ross, I68

New South Wales, H. H. contests, 9 John MacArthur, Father of, 165 represented by $\mathrm{H}$. H. in Amsterdam and London, ro

- Sir J. P. Hennessy offered the government of, 79

Newspapers, postage of, 237, 239, 271,277

Newton, Sir William, his correspondence with $\mathrm{H}$. H., 78

New York, I83, $25^{8}$

H. H. in, 105 
New Zealand, compulsory training in, 139

- Governorship of, II I offers support to the British Navy, I 54

- Penny Postage to, 3I, 2I7, 2I8, $27 \mathrm{I}$ I 84

Nice, H. H. at, IO2, 205

Sir C. G. Duffy at, 34,65

Nichols, Willie, songs by, I 43

Nineteenth Century, The, ix, II9

- A Morning with the P.M.G., 257

- postage of, 272, 277

Nobel Peace Prize, the, H. H. a candidate for, 242

Norfolk, the Duke of, as P.M.G., I 76 , I 78 -I 80

Northcliffe, Lord, 227

Northcote, Lord, Governor-General of Australia, 215

Norwich, 275

Dean Lefroy of, I86

Nürnberg, the, sunk by H.M.S. Kent, $4^{8}$

\section{$\mathrm{O}$}

O'Brien, Hon. Beatrice, her marriage, I 53

Obstructionist policy, the, I 27

O'Connell, Daniel, his trial, I68

O'Connor, T. P., his friendship with

H. H., ix, I3I-I37

Odell, " Harvest Home," I43

O'Grady, Mike, Io6

Omdurman, 20

Oxford pageant, the, I97

- University of, chess tournaments of, 54

Yeomanry, the, II

\section{$P$}

Paganini, method of, 198

Paget, Mr and Mrs Algernon, ix, I 20

Paisley, Earl Rosebery at, 216

Pall Mall Club, the, H. H. at, $\mathrm{I}_{4} 8$

Panama Canal, the, 35,67

Pankhurst, Christabel, apologizes for militancy, 2I

Parcel Post, the, 237, 238, 260, 276

Paris, 243, 274, 275

- H. H. in, I9O

$$
\text { telephonic communication with }
$$

London, 268
Parkes, Sir Henry, his influence on H. H., 67,166

Parks Government, the, 9

Parliamentary etiquette, $19,23,28$

Parnell, Charles, as a chess-player, 5I, 52

I6

H. H.'s friendship with, I5,

Parramatta, H. H. in, 5, 166

Party politics, Lord Charles Beresford on, 32

Pasture, Mrs Henry de la, 96

Patey, Admiral Sir George, Ior

Patriotism, Lord Charles Beresford on, 32

Patterson, A. B., quoted, I 74

Patti, Adelina, 233

Pau, H. H. in, 66

Peace, Sir Walter, Agent-General for Natal, I8I

Pearson, Arthur, 227

Peel, Rt. Hon. A. W., I 5

- Sir Robert, $\tau_{5}, 25,25 \mathrm{I}$

Penny Post, The, H. H. edits, 5

Penny Postage, the, viii, II

- Imperial, $\mathrm{H} . \mathrm{H}$. advocates, I75I 82, 2 I 7-22I

- supported by the Times, I75

Inland, I73

Ocean, I73

- Universal, I I I, I 74, I 82-I86, 208, 218

Perak, Sultans of, 76, 77

Peshawur, S.S., H. H.'s voyage on, 72

Philately, H. H.'s love of, 78

Phillips, John, wireless operator, 98

Phillips, Sir Owen, Chairman of the R.M.S., 94

- supports cable reform, 225

Pickford, Messrs, 2 I I

Pigott, Dr Turtle, I44

Pigott, Mostyn, I 43

Pilcher, R., 50

Pillar-boxes, 279

Pills, advertisement of, 205

Pirie, D. V., on Anglo-French postage, I 86

Plumbers, Worshipful Company of, 229

Plummer, Elward, 40

Plunkett, Sir Horace, 52

Poetry, H. H.'s love of, I2I

Pope, Alexander, Essay on Man 4.

Port Antonio, Jamaica, $\mathrm{H}$. $\mathrm{H}$, in 87

Port Kingston, S.S., 93

Port Raffles, I60 
Port Said, H. H. at, 225

Porter, Colonel Morton, I 20

Porter, Major Adrian, King's Messenger, I 02, I 20

Postal Cards, 269

Estimates, the, 209

Guide, the, 278

- Orders, poundage on, 20, 265

Reforms, advocated by $\mathrm{H} \mathrm{H}$.,

viii, $37,49,233-239,257-282$

- compensation questions, 2 I I

_- getting a letter back, I08

_ - for postage due, 65, 196, 277

49, I35, I 75-I86, 2 I 7-22I

- red book of stamps, 204, $27 \mathrm{I}$

Postal Union, the Congress at Washington, I 78

Congress at Rome, I84

Postmarks, system of, $84,85,205$, 209, 276, 277

Postmaster-General, the, "A morning with," 257-282

- harassed by H. H., I3, 49, 95, I 32, 245

Post Office, the evolution of, I7I-I 73

P rebellion in, $\mathrm{I}_{40}$

Post Office Savings Bank, 236, 275, $28 \mathrm{I}$

Post Office Vote, the, 24

Preferential tariffs, 276

Press Conference, first Imperial, 226

Protection, policy of, 32, 33

Punch, 62

\section{Q}

Queensland, 2I 7

Questions in Parliament, I4, 24, I32

R

Rae, Dr John, explorer, I45, I49-I 5 I

Raffles Bay, I 59

Raikes, Cecil, as P.M.G., I3, I33, I40, 202

Randles, Sir John, his letter to H. H., 55

Ranfurly, Earl, ex-Governor of New Zealand, I I I

Rawson, Mrs Arthur, founds the Imperial Chess Club, 55

Redmond, John, his friendship with H. H., I 37

Redmond, William, I23, I37

Registration fees, 277
Reid, Sir George, anecdotes of, 43 , 44 High Commissioner for Australia, 48, I 4I

- his tribute to H. H., vii-ix

Reid, Whitelaw, American Ambassador, I07, I4O, I9I-I94

Renown, S.S., 225

Renshaw, Colonel Charles, ix

Review of Reviews, The, 67

Rhodes, Rt. Hon. Cecil, on Penny Postage, I 54

Richavd III., Tree as, I09, I Io

Ridge, Pett, novels of, I 23

Riley, James Whitcomb, I47

Rio de Janeiro, H. H. in, 94, 95

Ritchie, M.P., 35

Roberts, Earl, I 40

- on Penny Postage, I 84

Roberts, Rev. C. F., 262

Robertson, J. P. B., I 5

Rochester, H. H.'s birth and childhood at, 3

Rome, H. H. in, 59, 66

- family, the, I65

Rome, Claude, $x_{3} 8$

Roosevelt, Alice, I07

Roosevelt, Theodore, as President, I07

his interest in postal questions, I9I, I95

Root, Senator Elihu, at the United Service Club, I 4 I

on Anglo-American Penny Postage, I94

Rose Lorraine, 6-8

Rosebery, Earl, on Penny Postage, 216

Rosmead, Lord, his friendship with H. H., I37

Rossi, Joannes Baptista, 6I

Rotherhithe, the M.P. for, 29, 30

Rougemont, Louis de, II5

Royal Colonial Institute, the, considers penny-a-word telegrams, 223 , 226

- H. H. a Fellow of, 242

Royal Society of Literature, the, H. H. a Fellow of, 242

Rumford, Kennerly, 42

Rural postmen, 280

Russell, Sir Charles, I5

- his love of chess, 5 I

Russell of Killowen, Lord, his friendship with H. H., 105, I 37

Russia, Labouchere in, 27

Rutherford, Watson, M.P., on H. H. as a chess-player, 54

Ryan, P. F. W., his Stuart Life and Manners, I7I 
Stanley, Lord, as P.M.G., I84, 202, $218-220$

Saba Pasha, his friendship with $\mathrm{H}$. $\mathrm{H}$.,

Salisbury, Marchioness of, 20

Salisbury, Marquess of, as Premier, I 76

H. H. on, $\mathrm{I}_{40}$

Lord Randolph on, 18

Sir C. G. Duffy on, 35

on H. H., 20

Sample Post, 200, 278

Samuel, Rt. Hon. Herbert, as P.M.G., ix, 49, 204-206, 228, 232, 245

Sir Saul, opposes Imperial Penny Postage, 2I 7

Sargent, John, I26, I47

Sassoon, Sir Edward, 35

- his interest in postal reform, I92

supports cable reform, 225

Saunderson, Colonel, I5

Savage Club, the, H. H. at, rog, r42I 44

Scotland, H. H. on, 58 , I I I

Seaman, Sir Owen, quoted, 62

Senham, Hennikers of, 3

Sevastopol, ro6

Stanley, H. M., on London, I42

Stead, W. T., H. H.'s intercourse with, 152

- his ghost, 67

Stephens, Brunton, I 66

Stevenson, R. L., I I 8

St George of England, Royal Society of, III

St Martin's-le-Grand, I8I

relations of $\mathrm{H}$. H. with, $\mathrm{I}_{5}, \mathrm{I}_{98}$, 203, 204, 209

Stone, Sir Benjamin, photographs by, 34 , 106

Storrie, A. L., quoted, 7 I

Strathcona, Lord, High Commissioner for Canada, 48, 49

his tribute to H. H., I 37

- supports penny-a-word telegrams, 223, 225

Strickland, Sir Gerald, Governor of N.S.W., Ior, I69

Strong, Sir Vesey, Lord Mayor of London, I39, 229-23I

Suffragettes, 2 I

Sullivan, Sir Arthur, anecdote of, I IO

Seychelles, Abdullah's banishment in the, 76, 77

Shamrock, the, 123

Shaughnessy, Sir Thomas, President of the C.P.R., 87

Shaw, Sir Charles, 52

Sheffield, I 55

Shelley, P. B., quoted, I2 I

Sheridan, R. B., quoted, 122

Shine, A. H., 5o

Simla, Viceregal Lodge, 35

Sinclair, Archdeacon, at Windsor, I 52

Singapore, 77

Skibo Castle, I 56

Smith, W. H., I 5, I 8

Snead-Cox, Mr, his tribute to, H. H., II 4

Society Islands, the, 187

South Africa, postal system of, I79

African War, the, 32, 227

America, H. H. in, 94, 95

Southampton, H. H. at, $94,{ }_{3} 8$

South Australia, 217

- Chief-Justice of, $7 \mathrm{I}$

Spender, J. A., 227

Spicer, Sir Albert, supports cable reform, 225

Stamfordham, Lord, 254

- meets Lord Blyth, I4I

Sunday, observance of, 46

post, the, $260,26 \mathrm{I}$

Swettenham, Sir Alexander, Governor of Jamaica, 88, 92

- Sir Frank, his Malay Sketches, 76

Swiftsure, wreck of the, I 59

Switzerland, postal system of, 271

Sydney, I 59

- H. H. in, 5-9, 95, 98, 101, 102, I66, I68

Samuel Bennett in, viii, 5

Sydney, H.M.A.S., ror

Symon, Sir Josiah, 7 I

\section{$\mathrm{T}$}

Talbot-Crosbie, Lindsay, I 20

Tamworth, M.P. for, 25

Tasmania, I 59

$-\mathrm{H}$. H. represents, in Berlin, ro

Telegrams, penny-a-word, 55, 199, $205,222-23 I, 245,258,268$

reply forms, 264-266

Telegraph Department, vagaries of, 2II, 266

Money Order, the, 201, 272, 273 
Telegraphic Conference in Berlin, International, I0, 8I

- reforms advocated I3, 24

Telephone service, the, 268

Temple, Archbishop, 39, 45

- Sir Richard, I5

Tennant, Sir David, Agent-General for the Cape, I8I

Tenterfield races, I 59

Thomas, Hon. Josiah, P.M.G. of Australia, 2I 5, 220

Thompson, Henry, 50

Thompson, Miss Skeffington, I 45

Thunderbolt, Captain, bushranger, I 58

Thurn, Sir Everard im, Governor of Fiji, 85

Times, The, ix, 5, 52, 67

- governed by Moberly Bell, I I 3

- Parnell forgeries in, I6

— supports H. H., I75. I8I, 20I, 2IO, 219

Timora Gold Field, Io

Tipperary, 65

Titanic, loss of the, 97, 98, I 52

Tokio, H. H. in, I05

Torch, H.M.S., 53

Torres Straits, I 59

Toryism in Canterbury, 39

Townshend, $\mathrm{Mr}$, I6I

Tree, Sir Herbert Beerbohm, as Richard III., I09, I I0

Trocadero, the, H. H. fêted at, 48

Truth, 27

Turkish bath, the, H. H.'s belief in, I35

Twain, Mark, anecdotes by, I03-I05

- his letter to $H$. H. on postage, I95-I97

Tweedmouth, Lord, ri I

\section{U}

United Service Club, the, I4I, I94

United States of America, divorce laws of, II 4

- H. H. in, 83-85

- chess tournament with the H.O.C., 52 92

land an armed force in Jamaica,

Penny Postage between England and, II, 36, 83, I35, I57, I88, I9I-I97, 207, 247

Universal Penny Postage, Duke of Argyll on, I I I

H. H. advocates, I74, I 82
V

Vaughan, Archbishop, on denomina. tional education, 9 - Father Bernard, anecdote of, I09

Victoria, Australia, 217

Vir C. G. Duffy in, I68

Victoria, Queen, anecdote of, I8o

- coronation of, I 20

— Diamond Jubilee of, I77

- her letter to H. H., 242

Vill visits Canterbury, 43

Villiers, Rev Henry Montague, his cable grievance, 2 II

Vivginian, S.S., 98

\section{W}

Wace, Dean, 40

on early rising, I03

Wacher, Dr Frank, 40

Wagga Wagga, N.S.W., I6r

Walker, Alexander, constable, I 59

Walking-sticks, H. H.'s collection of, 77

Wall, Edward Cant, secretary to H. H., II9

Wallace, $\mathrm{Mr}$, death of, $2 \mathrm{I}$

Waller, George Platt, American ViceConsul in Carlsbad, 248, 249

Walter, Arthur, encourages chess, 52

Walton, Sir Joseph, in Paris, I9o

Wanamaker, Hon. John, advocates Anglo-American Penny Post, 83, I9I, I92

his friendship with $H$. H., 4446,83, I 47

Ward, Dudley, M.P., anecdote of, 2 I

Ward, Frederick, bushranger, $15^{8}$

Ward, Hon. Mrs John, I07

Ward, Sir Joseph, advocates Penny Postage, I82, I84, 218

- in Canterbury, 43

- Prime Minister of N.Z., I39, I 54,230

War Office, the, 24

H. H. crosses swords with, 33

Warwick, Australia, I 59

Washington, 52

Postal Congress at, ${ }_{7} 8$

Way, Sir Samuel, entertains H. H., IOo

Webbe, A. J., his daughters, I23-I25

Webster, Sir Richard, as M.P., I5, 23

Weekly Graphic, The, ix 
Wellington, the Duke of, 33, 57 N.Z., $27 \mathrm{I}$

Wentworth, William Charles, quoted, I70

Westbury, Lord, his kindness to H. H., 249-252

Western Australia, 2 I 7 gold in, $\mathrm{r} 6$ government of, 79

West Indies, the, H. H. in, 87-94, I02

Westminster Bridge, I 8

Palace Hotel, the, I 78

Whips, Government, 22, 23, 27

Whittaker, T. S., 50

Whittingehame, gum-trees at, 20

Wickham, F., 262

Wicklow, Parnell in, I7

Wilkens, H. T., 50

William IV., coronation of, I20

Wilson, John, I80
Wireless Telegraphy, H. H. on, 228

Wolseley, Field-Marshal Viscount, on the education of officers, I55, r 56

Women Suffrage, H. H. as an advocate of, 2 I

Woodbridge, Suffolk, $27 \mathrm{r}$

Woolwich, officers' education at, ${ }^{5} 6$ Arsenal, 275

Worcester, I73

Y

Yokohama harbour, 95

York, 260

\section{Z}

Zurich, H. H. at, $25 \mathrm{r}$ 



